ISSN 2238-6262

Revista Brasileira de Estratégia e Relações Internacionais

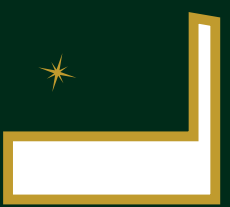
Brazilian Journal of Strategy \& International Relations

Brazilian Foreign Policy and South-South Cooperation
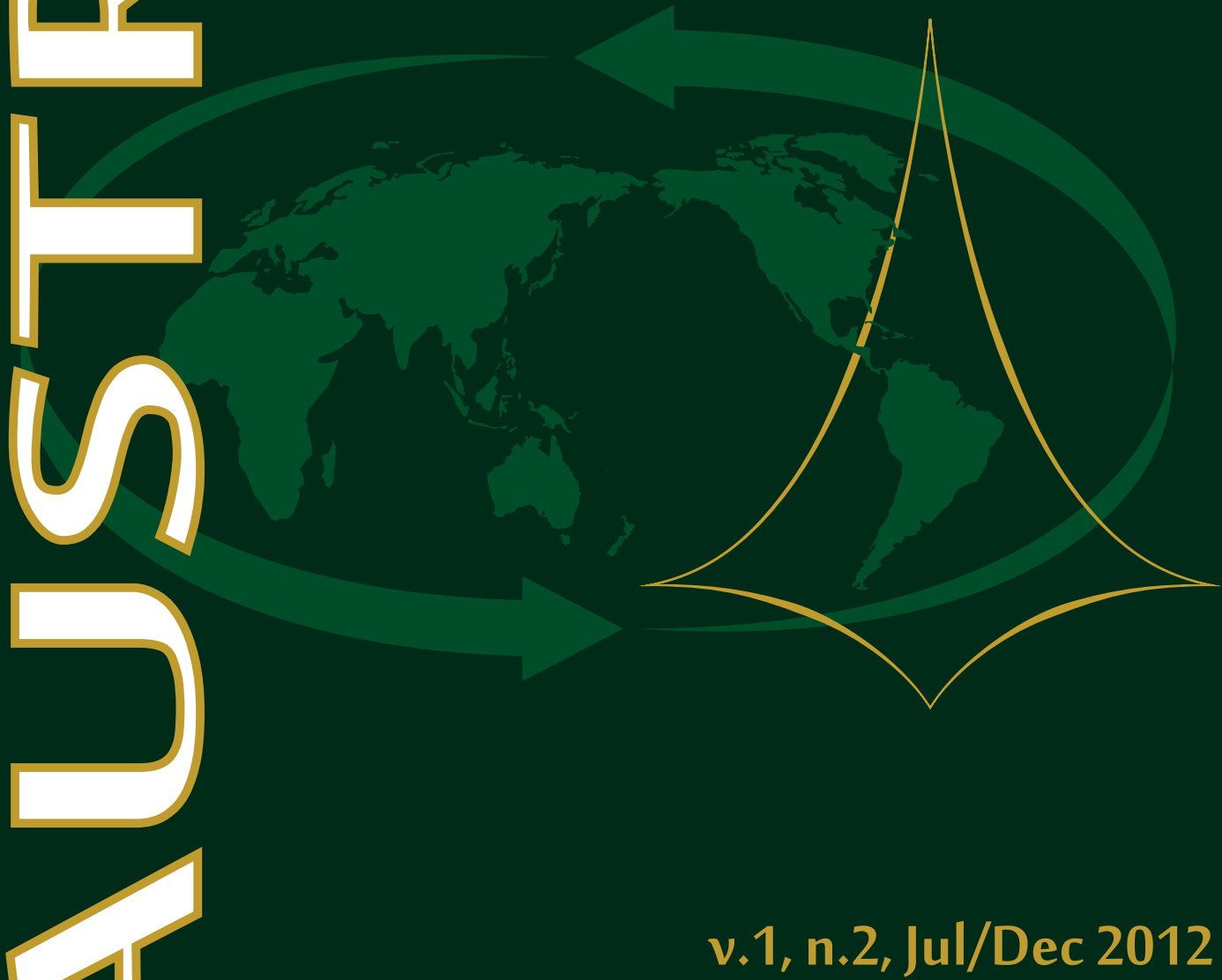

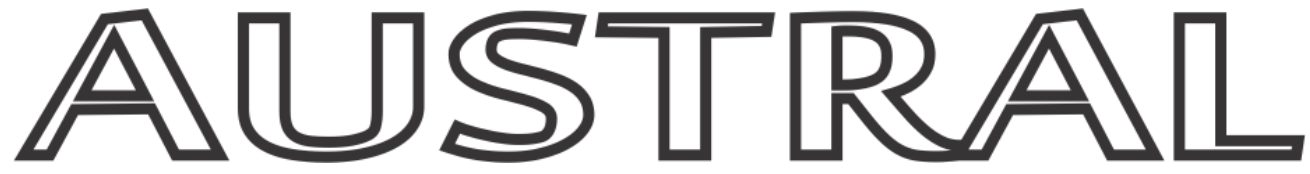

Revista Brasileira de Estratégia e Relações Internacionais Brazilian Journal of Strategy \& International Relations

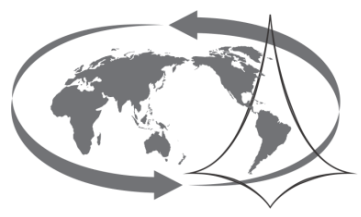

Brazilian Foreign Policy and South-South Cooperation

Porto Alegre, n.1, v.2 |Jul/Dec. 2012

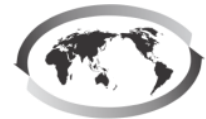

PPGEEI-UFRGS

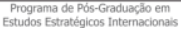

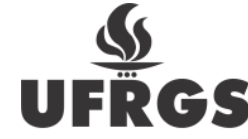

UNIVERSIDADE FEDERAL DO RIO GRANDE DO SUL

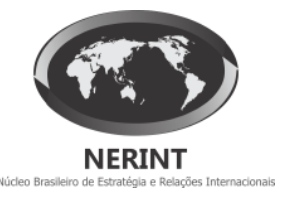


This work was supported by IPEA, a research and development entity of the Brazilian Government, and by the Government of Rio Grande do Sul.

O presente trabalho foi realizado com o apoio do IPEA, entidade do Governo Brasileiro voltada para a pesquisa e desenvolvimento, e do Governo do Estado do Rio Grande do Sul.

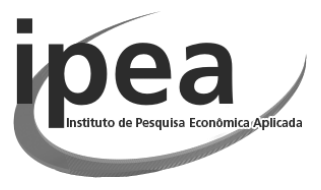

\section{Rio}

Grande

do Sul 


\section{ABOUT THE JOURNAL}

AUSTRAL: Brazilian Journal of Strategy \& International Relations is an essentially academic vehicle, linked to the International Strategic Studies Doctoral Program (PPGEEI) of the Faculty of Economics (FCE) of the Universidade Federal do Rio Grande do Sul (UFRGS) and to the Brazilian Center for International Relations and Strategic Studies (NERINT) - a research center of the Latin American Institute for Advanced Studies (ILEA/UFRGS). Its pluralist focus aims to contribute to the debate on the international political and economic order from the perspective of the developing countries.

The journal publishes original articles and book reviews in English, Portuguese or Spanish about themes that lie in the vast area of Strategy and International Relations, with special interest in issues related to developing countries and the South-South relations, their security issues, the economic, political and diplomatic development of emerging nations and their relations with the traditional powers. The journal's target audience consists of researchers, specialists and postgraduate students of International Relations.

The journal will try, through its publication policy, to ensure that each volume has at least one author from each of the great southern continents (Asia, Latin America, Africa), in order to stimulate the debate and the diffusion of the knowledge produced in these regions. All of the contributions will be subjected to a scientific review.

\section{SOBRE A REVISTA}

AUSTRAL: Revista Brasileira de Estratégia e Relações Internacionais é um veículo essencialmente acadêmico, ligado ao Programa de Pós-Graduação em Estudos Estratégicos Internacionais da Faculdade de Ciências Econômicas da Universidade Federal do Rio Grande do Sul/UFRGS e ao Núcleo Brasileiro de Estratégia e Relações Internacionais - NERINT, Centro de pesquisa do Instituto Latino-Americano de Estudos Avançados da UFRGS. O enfoque pluralista está vinculado à contribuição para o debate sobre a transição da ordem política e econômica internacional, a partir de uma perspectiva dos países em desenvolvimento.

A revista publica artigos e resenhas inéditos nos idiomas inglês, espanhol e português cuja temática se situe na área das relações internacionais, com ênfase na política internacional dos países em desenvolvimento e que tenham como foco principal as Relações Sul-Sul, as questões de segurança, o desenvolvimento econômico, político e diplomático das nações emergentes e suas relações com as potências tradicionais. Tem como público alvo pesquisadores, especialistas e pósgraduandos da área de Relações Internacionais.

A Revista Austral procurará, na sua política de publicação, que cada número conste de, ao menos, um autor de cada grande continente austral (Ásia, América Latina, África) com vistas a estimular o debate e a articulação de conhecimento produzido nestas regiões. Todas as contribuições são submetidas à avaliação científica. 


\section{AUSTRAL}

Editorial Board Equipe Editorial

Editor Editor Chefe

Paulo Visentini (Universidade Federal do Rio Grande do Sul, Brazil)

Deputy Editor Editor Adjunto

Marco Cepik (Universidade Federal do Rio Grande do Sul, Brazil)

\section{Editorial Board Comitê Editorial}

Adam Habib (University of Johannesburg, South Africa)

André Luiz Reis da Silva (Universidade Federal do Rio Grande do Sul, Brazil)

André Moreira Cunha (Universidade Federal do Rio Grande do Sul, Brazil)

Érico Esteves Duarte (Universidade Federal do Rio Grande do Sul, Brazil)

Fábio Morosini (Universidade Federal do Rio Grande do Sul, Brazil)

Gladys Lechini (Universidad Nacional de Rosário, Argentina)

Immanuel Wallerstein (Yale University, United States of America)

Marcelo Milan (Universidade Federal do Rio Grande do Sul, Brazil)

Ruchita Beri (Institute for Defence Studies an Analyses, India)

Edition Assistant Assistente de Edição

Guilherme Ziebell de Oliveira (Universidade Federal do Rio Grande do Sul, Brazil)

\section{Editorial Committee Conselho Editorial}

Amado Luiz Cervo (Universidade de Brasília, Brazil)

Antônio Carlos Lessa (Universidade de Brasília, Brazil)

Antonio Jorge Ramalho (Universidade de Brasília, Brazil)

Bertrand Badie (Sciences Po, France)

Boris F. Martynov (Russian Academy of Sciences, Russia)

Carlos Arturi (Universidade Federal do Rio Grande do Sul, Brazil)

Carlos Aurélio Pimenta de Faria (Pontifícia Universidade Católica de Minas Gerais, Brazil)

Chris Landsberg (University of Johannesburg, South Africa)

Hüseyin Bağci (Middle East Technical University, Turkey)

Ilter Turan (Istanbul Bilgi University, Turkey)

José Ariosa Pérez (Universidad de la Habana, Cuba)

Liu Youfa (China Institute of International Studies, China)

Lotfi Kaabi (Institut Tunisien des Études Stratégiques, Tunisia)

Luis Augusto Estrella Faria (Universidade Federal do Rio Grande do Sul, Brazil)

Mamoudou Gazibo (Université de Montréal, Canada)

Marcos Costa Lima (Universidade Federal de Pernambuco, Brazil)

Maria Regina Soares de Lima (IESP, Universidade do Estado do Rio de Janeiro, Brazil)

Mehdi Parvizi Amineh (University of Amsterdam, Netherlands)

Melissa H. Conley Tyler (Australian Institute of International Affairs, Australia)

Monica Hirst (Universidad Torcuato di Tella, Argentina)

Nikolai Mikhailov (Russkiy Mir Foundation, Russia)

Sean W. Burges (Australian National Centre for Latin American Studies, Australia)

\section{Contact Contato}

Universidade Federal do Rio Grande do Sul - Faculdade de Ciências Econômicas

Programa de Pós-Graduação em Estudos Estratégicos Internacionais

Av. João Pessoa, 52 sala 33A - $3^{\circ}$ andar - CEP 90040-000 - Centro - Porto Alegre/RS - Brazil

Phone: +55 513308.3963 Fax: +55 513308.3963 Email: austral@ufrgs.br 


\section{AUSTRAL}

\section{Volume 1, Number 2 (Jul/Dec 2012)}

Editor's Note

Paulo Fagundes Visentini

Presentation.

Amado Luiz Cervo

The Lessons from the Euro Experience

Richard Griffiths

Brazil in the Current World Order.

Amado Luiz Cervo

Neo-developmentalism and the Search of a New International

Insertion....

Giorgio Romano

Teaching and research on Foreign Policy in the Field of International

Relations of Brazil.

Carlos Aurélio Pimenta de Faria

Brazil in face of the Chinese Rise: the Risks of Regressive

Specialization.

André Cunha, Marcos Lélis, Julimar Bichara, Manuela de Lima

The Impact of the International Crisis on Brazil's Trade with the Other BRICS (Russia, India, China and South Africa)

André Luiz Reis da Silva, Luiza Peruffo

Media and Foreign Policy in Lula's Brazil.

Guilherme Casarões

Developing from the South: South-South Cooperation in the Global

Development Game

Sean Burges

Colonial Globalisation to Postcolonial Globalisation: Non-Alignment and South-South Cooperation.

Aditya Mukherjee

Partners

Submission Standards.

The responsibility for the content of the articles is of their respective authors.

A responsabilidade do conteúdo dos artigos é de seus respectivos autores.

Austral: Brazilian Journal of Strategy \& International Relations - v.1 n.2 Jul/Dec.2012 


\section{Paulo Fagundes Visentini ${ }^{1}$}

Austral: Brazilian Journal of Strategy and International Relations is the first Brazilian academic journal of the area to be edited entirely in English in print (and bilingual Portuguese-English in electronic form) as a way to broaden the dialogue with foreign students. The first number analyzed the crisis and the transformations of the international system, attracting mainly foreign authors as an incentive of exchange with other institutions. Now in its second number, AUSTRAL focuses on the Brazilian Foreign Policy and South-South Cooperation, drafted mainly by Brazilian authors and presented by Professor Amado Luiz Cervo, the Dean of this theme, which makes us very proud.

Political aspects are analyzed in very original perspectives: the economic impacts, such as the successes and risks in trade with other emerging markets; and also internal impacts, such as the role of the media and the teaching of the subject in Brazil. Authors from India and Australia have deep insights into the South-South cooperation, but this number starts with a topic of utmost relevance and importance, the crisis of the Euro, written by a European specialist.

The widespread acceptance obtained when it was released, now consolidates and deepens with the publication of its second number. AUSTRAL was officially released during the Brazilian Seminar of Strategic and International Studies (SEBREEI), event held in Porto Alegre and organised by the International Strategic Studies Doctoral Program of the Faculty of Economics of the Universidade Federal do Rio Grande do Sul, the State

${ }^{1}$ PhD, London School of Economics and CNPq researcher. Coordinator of the International Strategic Studies Doctoral Program and International Relations Professor at Universidade Federal do Rio Grande doSul (UFRGS). (paulovi@ufrgs.br) 
Government of Rio Grande do Sul and the Brazilian Centre of Strategy and International Relations (NERINT/ILEA/UFRGS). The event was attended by speakers from all nations of the BRICS, in addition to Latin American countries.

Thus, the Journal is linked to the activity of postgraduate education and research since its inception, fully integrated into the great contemporary debates of strategic studies and international relations.

We would like, once again, to thank the financial support from IPEA for the publication of the second number and the Relations Coordination of the Government of the State of Rio Grande do Sul by supporting national and international distribution, as well as Gabriela Perin for the translations, Airton Martins, Livi Gerbase and Pedro Alt for the review, and especially to Guilherme Ziebell de Oliveira, our dedicated Editorial Assistant.

Paulo Fagundes Visentini Editor 


\title{
PRESENTATION: THE FOREIGN POLICY OF BRAZIL
}

\author{
Amado Luiz Cervo ${ }^{1}$
}

The students of foreign policy of Brazil moved from the old diplomatic history, through the history of foreign policy, to reach the international insertion of the country. The concept of insertion involves three components: the diplomatic negotiation, the foreign policy which adds values and national interests to the former and the movement of non-state actors who act externally in pursuit of specific interests. From this concept of integration, the paradigmatic analysis distinguishes four historical impulses, called paradigms, to constrain the functionality of foreign policy, namely: the primary-exports model from Independence to 1930; the developmental model, from 1930 to 1989; the neoliberalism of the 1990s; and what we call the Logistic State, in the $21^{\text {st }}$ century.

When the University enters the areas of teaching and research Brazilian foreign relations, since the $1970 \mathrm{~s}$, the studies multiplied, hitherto reserved primarily to the question of the diplomatic corps. Although it is possible to do so, scholars rarely isolate, in their analysis, one of the three components of insertion. This is because, in recent decades, proved to be clear and understandable not only the close links between diplomacy, foreign policy and foreign relations, but also the rise of society and the new relationship between society and State.

The development to be promoted submits itself to the national impulse since the rise of Getúlio Vargas in the 1930s. The development would be guided

\footnotetext{
${ }^{1}$ Head Professor of International Relations at the University of Brasilia. Emeritus. Senior Researcher of National Research Council-CNPq (http://www.cnpq.br/ - Lattes platform).
} 
via industrialization as the long-term ratio, but was designed differently, by the leaders over time, as to the mechanisms, steps, ways to relate internal and external spheres, and the maturity of the process. The liberals of all decades have understood development, primarily, as an external responsibility of the more advanced nations, who would meet the national plan with the capital, enterprises and technologies. Nationalists of all time conceived it, primarily, as internal responsibility, to be carried out through own inputs. The followers of the Dependent and those of the Independent theories divided, thus, the opinion into two branches, which fought for power, i.e., the State.

Drawing strength from these two groups, the liberal and the autonomist, Brazil's national composition resulted balanced, liberal and national, open and autonomous, tied to the world and to its own path. Diplomacy, foreign policy and international relations are increasingly conditioning one another, over the decades, in such a way that the insertion resulted remarkably balanced.

One of the first requirements of this model would be the autonomy of foreign policy, without which the development strategy would escape from national control. Designed as a decision-making autonomy, as far back as the 1930 s, foreign policy was based, however, on cooperation with foreign countries and the non-confrontation. Obviously, liberals tended to the decisive subservience and the dependent insertion, as much as the nationalists were prone to confrontation and isolation. However, balance prevailed as a guideline over time. In short, the political calculation would have to include the reciprocity of benefits of the insertion when considering one's own interests and those of the others.

The Brazilian model of integration, based on this vision of international relations in which nations cooperate with one another, certainly does not rule out the inevitable clash of interests whose overcoming, by reconciliation or not, is a duty of diplomatic negotiation. If the management of the link between the distinct national and international interests, particularly the economic ones, has been historically difficult in the Brazilian experience, even harder the attempt to reconcile values among nations, based on Brazil's own vision of the world, should be. West, socialism, capitalism, clash of civilizations, among other elements, interfered their ideological and cultural dimensions in thinking and decision-making process as inputs and as national challenges. Sometimes such 


\section{Amado Luiz Cervo}

inputs deepened the rift between liberals and independists, as witnessed in the controversy between intellectuals and rulers in the $1960 \mathrm{~s}$, a debate that arose again at the turn of the millennium, at the time of the neo-liberal experience.

Ethnically heterogeneous and culturally plural, the national identity of Brazil, as a nation with enormous social inequalities and ambitious of development, served as the source of external conduct. The relationship between national identity and international insertion rendered the coexistence of differences and pacifism as values and goods in their own right. However, managing values in international politics has proved itself even more troublesome than managing material interests or security. The global scene is made up of the imposition of its own values, which are understood as systemic bargains by governments and societies in which distinct national identities are constituted.

The foreign policy of Brazil moves, as mentioned before, toward its international insertion maturity. Thus, the $21^{\text {st }}$ century is an advanced point of arrival of a new country, searching its own destiny. What are the traits of the Brazilian model of international insertion in the $21^{\text {st }}$ century?

Nothing of neo-developmentalism is observed in the Brazil of the $21^{\text {st }}$ century if we consider as paradigm the Argentinian experience, which is mainly composed of a return of the exacerbated deviations of developmentalism: renationalization, protectionism, monetary instability, and economic and financial isolation. The Latin America of the $21^{\text {st }}$ century does not realize the consensus of a paradigm, as it had done from the independence until 2000. The international rise of Brazil in the $21^{\text {st }}$ century detaches itself from its neighbors and that is precisely due to its progress to systemic maturity, which better incorporates the benefits of development, adds to it the convenient interdependence of liberalism, but extends the autonomy inherent to the strategic calculus of foreign policy, all surrounded by balance.

The key determinant of international insertion of Brazil in the $21^{\text {st }}$ century is the emergence of society. Over six decades, it was up the State to conceive and dictate to a society, which was almost inert to the nature and requirements of national interests, as well as the values of identity, and drag this society towards development. The neoliberal paradigm of the $1990 \mathrm{~s}$, weakening the State and using external subservience, induced beneficial result 
to nation building. The $21^{\text {st }}$ century matures this evolution, which draws strength from the past, given that various trends in designing and implementing the policy have always been present in the national tradition. Thus emerges the society, with organized segments, active leaders, specific interests to perform, and willing to move.

The functionality of Brazilian foreign policy in the $21^{\text {st }}$ century is changed in its essence. A new pattern of relationship is established between State and society, never before having been cultivated with such intensity. The connection involves the three components of international insertion: diplomacy, foreign policy and international relations. The State transfers power and responsibility to non-governmental actors to promote the development and concedes part of the strategic decision in foreign policy.

At the time of developmentalism, primarily the State had the command of diplomacy, foreign policy and international relations. At the time of neoliberalism, this command was delivered to market forces. In the $21^{\text {st }}$ century, the innovation is based on bringing society into the State, whose functionality is to administer, from the top, the interests of the segments that act externally, which are sometimes conflicting interests, and aggregate them into the greater national interest. This new pattern is called the Logistic State, since it is no longer the Business State, nor the Neglect State, but only the driver of the society in pursuit of external opportunities or even inventor of opportunities, besides being the responsible for the harmonization of its segments.

The diplomatic conduct during the Logistic State is guided by the principles of reciprocity of benefits among nations in the field of multilateral negotiations and by the strengthening of bilateral partnerships, since these partnerships also extend the interests and national power. Among the stable and appreciated, in economic, political and geopolitical terms, partnerships of Brazil, we can cite: England, the United States, Argentina, Germany, Italy, France, Japan, China, Portugal, Spain, among others, which include the entire neighboring area of Brazil.

The regional integration becomes, in the $21^{\text {st }}$ century, an instrument of support to Brazilian globalist call. This is accomplished through the influence on the international scene in order to transform the rules of order and through more robust links of global interdependence, particularly through the outward expansion of Brazilian companies. The integration preserves, however, as 


\section{Amado Luiz Cervo}

perennial, the function to maintain and cultivate the climate of political understanding in South America, perhaps in Latin America, since its neighbors constitute a strategic reserve needed for the global goal to be achieved.

In three areas of external action, the evolution to the systemic maturity produces the best effects. On the one hand, regional integration builds the environment of political understanding and cordial relations, although, given the diversity of national designs and models of integration in the region, it eventually sacrifices the Brazilian project of productive integration, which would come alongside the country's economic internationalization. Secondly, the strengthening of ties with emerging countries, among which Brazil finds itself. The calculation of benefits contaminates rulers and social leaders. Emerging countries are more likely, when compared with the countries of the old advanced capitalist core, to consider the reciprocity of benefits in the rules that compose the international order; they are more likely to overcome asymmetries among the nations; and, finally, they share the concept of international security that replaces the strategy of violence, implemented by NATO in the Second World War, with the strategy of conciliatory negotiation in face of conflicts.

The most tangible result of the evolution to maturity is, however, found in the internationalization of the Brazilian economy. A shy movement until around 2005, it is subsequently reinforces and geographically shifts: from South America to North America, to Africa and Europe, Brazilian capitals and companies move and establish economic interdependence in conditions of systemic operation.

The efficiency limits of the Brazilian model of international insertion are created, primarily, internally, in the form of obstacles to the achievement of results. In the security area, there are the abandonment of the military autonomy project conceived in the $1970 \mathrm{~s}$ and the neglect of the defense industry. In the field of utilization of internal and external investments, the greatest obstacles put on evolution to maturity abound: excessive tax burden, high interest rates, bloated bureaucracy and poor infrastructure. In the sphere of the relationship between State and society, the biggest obstacle is the low technological innovation derived from the lack of public incentives aimed at education for innovation and the traditional low propensity of Brazilian 
business community to innovate, except for the agribusiness. These constraints tend to weaken both the level of competitiveness of the production and the service systems in the domestic and the foreign trade and outward expansion of Brazilian enterprises.

*Translated by Gabriela Perin 


\section{THE LESSONS FROM THE EURO EXPERIENCE}

\section{Richard Griffiths ${ }^{1}$}

Twenty years ago, amid a great fanfare of enthusiasm, the Treaty of Maastricht created the European union and inaugurated the process for creating a single European currency for most of the then members (except the UK and Sweden, and later Denmark, that were given a temporary exemption) and all future members. Twenty years later, the anniversary of the treaty passed almost unnoticed (EUROPEAN POLICY CENTER, 2012). On that day, however, the impact of the treaty was never far from the headlines, as had also been the case for almost every day over the previous months. The Lehman brothers bankruptcy in September 2008 not only triggered a financial crisis that threatened to engulf the world, but it set in motion a series of shocks that have since reverberated through the Euro-area. It is fair to say that the crisismanagement has not been an example of stream-lined efficiency, and there are lessons to be learned from that experience.

However, the development of the Euro, and the crisis that has subsequently engulfed it, holds lessons in another direction. The European Union has long been held as a model, or an inspiration, for other experiments in regional cooperation and integration, including Mercosul, ASEAN and SADC. The model embodied a sequence of steps leading to 'ever closer union' that moved from a free trade area through a customs union and a single market and culminated in economic and monetary union. With the signing and implementation of the Treaty of Maastricht, the European Union had

\footnotetext{
${ }^{1}$ Professor of Social and Economic History, Leiden University. (r.t.griffiths@hum.leidenuniv.nl)
} 
embarked on the penultimate step in this progression. But only half of it - a monetary union without a fiscal union. The Euro-crisis has now called that achievement into question and, in the process, undermined the authority of those espousing a European route towards closer integration, both for themselves as well as for other nations. As a convinced federalist, myself, I would not recommend abandoning the European example altogether, but if there is a lesson to be learned from this sorry episode, it is this: "if you are going to do it, do not do it this way".

This article examines the European experience with economic and monetary union from three perspectives - the design, the implementation and the management of the euro - before exploring the implications of the current crisis.

\section{The Design}

The decision to embark on the path towards economic and monetary union was taken after a period of remarkable exchange-rate stability in Western Europe. Introduced in 1979, it built on the experience of the exchange-rate mechanism (ERM) which had tied members exchange rates to a band of 2.25 per cent either side of par (except for Italy which was given a band of 6 per cent) and which had enhanced central bank cooperation to maintain the parities. Its introduction, however, had coincided with the second oil crisis and the system lurched from one crisis to the other, each being resolved by a devaluation or revaluation within the system to maintain the illusion that it remained intact. It was similar to a 'crawling peg' arrangement, but to dignify it with this description would be totally to exaggerate the orderliness of its workings and to forget the whiff of fear surrounding its operation. Within the space of three and a half years, a gap on almost 30 per cent had opened up in the exchange rates of the strongest (German DM) and weakest (Italian Lire) currencies. But then French economic policy converged with the rest, and a calm descended on the markets. The pervious turmoil was conveniently forgotten (JORDANWAGNER, 1994). Little now seemed to disturb the serenity of European exchange rates and toward the end of the decade several non-members joined the system - Spain in June 1989, the UK in October 1990 and Portugal in April 1992. It was against this backdrop that in February 1992 that the Treaty of Maastricht was signed (ISSING, 2008). 


\section{Richard Griffiths}

The design for economic and monetary union was based on five requirements that had to be met before being accepted into the single currency. First, countries had to have maintained stable exchange rates within the ERM for two years preceding membership. There then followed two fiscal targets the stipulation that the annual government deficit should not exceed 3 per cent and that the level of sovereign debt should be no higher than 60 per cent. Presumably assuming that these requirements were met, there followed two further targets (or consequences) for the rates of inflation and for the cost of long-term borrowing. But these were given a further tweak in the direction of monetary prudence by expressing the targets not in terms of the average for the group, but in terms of the three lowest in the group, regardless of their relative size or importance. Thus inflation was not to exceed this target by more than 1.5 percentage points and long-term interest rates were not to be more than 2 percentage points higher. Generally, these requirements were perceived at the time to be deflationary and this was interpreted as a concession to German demands as the price for surrendering its own domestic currency, which had been exceptionally successful in this respect. And what was good for Germany was presumably good for the rest of us as well (GARRETT, 1993).

Although the design has the virtue of simplicity, there are several curious deficiencies. For a start, the target for the deficit is absolute and only in one direction. It offers no opportunity for offsetting better performances (lower deficits or even surpluses) against an overshoot. If a deficit comes as a result of a recession, there is still an obligation to impose a deflationary budget. There is no scope at all for the kind of deficit financing engaged upon by the US in the shadow of the recession following the Lehman crisis and staying within the rules. Secondly, there is an inconsistency between tolerating a government deficit, albeit 3 per cent, and the objective of holding down the level of external sovereign debt. The only way to avoid steadily accumulating a relatively greater debt is either to grow faster than 3 per cent that is added to the debt burden (BUITER; CORSETTI; ROUBINI, 1993). Growing consistently, or even sporadically, faster than 3 per cent per annum is something that the more advanced European economies have struggled to do since the first oil crisis of 1973. On the other hand, growth 'convergence' for the less advanced economies was almost a religion among European economists, as they utilized untapped 
productivity resources and invested the convergence or cohesion funds transferred to them from the EU budget. Unfortunately, the recipe for growth usually entailed a trade-off in terms of higher inflation (FINGLETON, 1999; LEONARDI, 1995). This, in its turn would create a further problem. Locked first into fixed exchange rates, which precluded any currency depreciation, and later locked into a single currency and, furthermore, deprived of domestic monetary instruments, there were few options for dealing with the cumulative inflationary results. Finally, the interest rate target is an implied derivative from achieving the prescribed budget discipline and seem to be left to the mercy of the markets. This is eminently sensible, if the market is assumed to operate rationally and predictably. If it does not, however, governments are left with pitifully few short-term policy measures to alleviate the situation, and so too were the officials of the European Union. The stance of the monetary authorities was to be that there would be no 'bail-out' of economies in difficulties and therefore there was no provision of funds to cover just such an eventuality.

\section{Implementation}

The Maastricht treaty envisaged three steps whereby the new European currency would be created. In the first phase, capital controls would be removed and inter-bank cooperation would pave the way for the creation of a more central monetary authority. The second stage began with the creation of a European Monetary Institute and the five criteria agreed in Maastricht were enshrined in a Stability and Growth Pact, which was to be monitored by the European Commission. At the end of this stage, exchange rates would be locked together and the European Central Bank would be established. At this stage the euro was introduced as a means of transactions, but the launch of the currency into circulation would wait for four years (ISSING, 2008). That moment took place on $1^{\text {st }}$ January 2002. I was in Rome that day and still remember how, at the end of the day, I examined the loose change in my pocket to discover also coins minted in Germany, Ireland and the Netherlands. I should add that the novelty soon wore off. By then, however, things were already going badly wrong.

In May 1998 eleven members of the EU were declared to have met the conditions for euro membership and became the first wave to adopt the new 


\section{Richard Griffiths}

currency. Two other members, namely Denmark and the UK, had acquired optout clauses. This left only Greece and Sweden as members deemed ineligible, and Greece was admitted into the new currency in January 2001. For the record, all subsequent members of the European Union assumed the obligation to join the euro area, when conditions had been met. Slovenia did so in 2007, Cyprus and Malta joined the following year, Slovakia acceded the year after that and, finally in 2011 Estonia became a member.

But let us return to those heady halcyon days of Europhoria as countries lined up to join the new currency area. One criteria was that they should have a government debt ratio of no more than 60 per cent of GDP, but should it be higher at the moment of entry, that it should be diminishing at a "satisfactory pace". If we look at the statistics that policy-makers had before them at the time, in the two years before joining, three countries - Belgium, Italy and Greece - had debt ratios already towering above 100 per cent of GDP. Although they showed some decline this was at a rate that would still leave them far outside the target range two decades later. Greece too, had a debt ratio hovering around 100 per cent. Five other members - Austria, Germany, the Netherlands and Portugal and Spain - had debt ratios between 60 and 70 per cent.

Table 1: Government Debt:GDP Ratio (\%)

\begin{tabular}{|c|c|c|c|c|c|c|c|c|c|c|c|}
\hline \multicolumn{2}{|c|}{ Austria } & \multicolumn{2}{c|}{ Belgium } & \multicolumn{2}{c|}{ Finland } & \multicolumn{2}{c|}{ France } & \multicolumn{2}{c|}{ Germany } & \multicolumn{2}{c|}{ Ireland } \\
\hline 1997 & 1998 & 1997 & 1998 & 1997 & 1998 & 1997 & 1998 & 1997 & 1998 & 1997 & 1998 \\
\hline 66.1 & 65.6 & 124.7 & 121.3 & 59.0 & 57.3 & 57.3 & 58.2 & 61.7 & 61.4 & 65.8 & 59.2 \\
\hline \multicolumn{2}{|c|}{ Italy } & \multicolumn{2}{|c|}{ Luxembourg } & \multicolumn{2}{|c|}{ Netherlands } & \multicolumn{2}{c|}{ Portugal } & \multicolumn{2}{c|}{ Spain } & \multicolumn{2}{c|}{ Greece } \\
\hline 1997 & 1998 & 1997 & 1998 & 1997 & 1998 & 1997 & 1998 & 1997 & 1998 & 2000 & 2001 \\
\hline 123.2 & $\mathbf{1 2 1 . 9}$ & 6.7 & 6.9 & 73.4 & 71.5 & $\mathbf{6 2 . 5}$ & $\mathbf{6 0 . 8}$ & $\mathbf{6 8 . 1}$ & $\mathbf{6 6 . 5}$ & $\mathbf{1 0 2 . 8}$ & $\mathbf{9 9 . 7}$ \\
\hline
\end{tabular}

Source: European Commission, European Economy. Statistical Annex 1998 and 2001

If the Maastricht treaty had been taken seriously, the introduction of the Euro in 1999 should have taken place with seven fewer members than it did, and Greece should not have been allowed to join two years later. This, of course, is where politics enters the frame. A major step forward on the road to integration without four of the six founding members of the European Union was plainly unthinkable. Equally a monetary union comprising only Finland, France, Ireland and Luxembourg would have made no economic sense 
whatsoever. So, for the first time, and not for the last, the details of an agreement were pushed aside to make way for political expediency. And, having admitted Belgium and Italy with excessive sovereign debt ratios, the EU was scarcely in a position to extend the courtesy to Greece whose debt ratio appeared less bad than either of these. Policy-makers work with figures that they have to hand, but these figures are often revised afterwards either because the data itself is updated or because definitions have shifted. For debt ratios these revisions over time have been favourable, and would have allowed Portugal to qualify for euro-membership on this criteria. For Greece, however, the situation was slightly worse(EUROPEAN COMISSION. European Economy, Statistical Annex, 2011).

Table 2: Net government borrowing (-) or lending (+) as \% gdp

\begin{tabular}{|l|l|l|l|l|l|l|l|l|l|l|l|}
\hline \multicolumn{2}{|c|}{ Austria } & \multicolumn{2}{c|}{ Belgium } & \multicolumn{2}{c|}{ Finland } & \multicolumn{2}{c|}{ France } & \multicolumn{2}{c|}{ Germany } & \multicolumn{2}{c|}{ Ireland } \\
\hline 1997 & 1998 & 1997 & 1998 & 1997 & 1998 & 1997 & 1998 & 1997 & 1998 & 1997 & 1998 \\
\hline-2.8 & -2.6 & -2.6 & -2.3 & -1.4 & -0.2 & -3.1 & -3.0 & -3.0 & -2.6 & +0.6 & +1.2 \\
\hline \multicolumn{3}{|c|}{ Italy } & Luxembourg & \multicolumn{2}{|c|}{ Netherlands } & \multicolumn{2}{c|}{ Portugal } & \multicolumn{3}{c|}{ Spain } & \multicolumn{3}{c|}{ Greece } \\
\hline 1997 & 1998 & 1997 & 1998 & 1997 & 1998 & 1997 & 1998 & 1997 & 1998 & 2000 & 2001 \\
\hline-3.0 & -3.7 & +1.6 & +1.0 & -2.1 & -2.9 & -2.7 & -2.4 & -2.9 & -2.4 & -2.7 & -3.1 \\
\hline
\end{tabular}

Source: European Commission, European Economy. Statistical Annex 1998 and 2001

A second Maastricht criteria was that current government deficits should not exceed 3 per cent of GDP. At first sight, the record on this score was remarkably good but the results conceal a great deal of statistical and definitional creativity. Pension funds were creamed and capital assets sold and included under current revenue; parts of government debt were conveniently parked out of sight and GDP figures were massaged upwards, by as much as 1020 per cent (BOS, 2008. FN 15). The impact of changes in methods and definitions in the Netherlands in 2001, for example, to raised its GDP by 4.5 per cent and reduced its debt ratio from 52.95 to 50.7per cent (CBS, Press Release, 1.6.2005). There was plenty of room for further revisions, if efforts were taken to include the 'black economy' in official estimates as Italy did in 1987, thereby, in one leap, overtaking the UK as the world's fifth largest economy (SIESTO, 1987). Even so, Italy and Greece still failed to meet the Maastricht criteria on this point, but were still admitted. The reason was simple. If one was going to ignore a mountain of debt, who was going to quibble over a couple of decimal 


\section{Richard Griffiths}

points? In this particular case, historical revision had not been too kind to Portugal, Spain and Greece, all of which now have fallen above the three percent range and therefore the official qualification threshold.

\section{Management}

Once the Euro had been introduced, it was for the European Central Bank and the ministers of finance of the Eurozone to manage the new currency. The backbone for monetary discipline was the so-called Stability and Growth Pact, that took over in their entirety all the Maastricht criteria. One of these was that budget deficits should be no higher than 3 per cent of GDP. This was first seriously challenged in 2001-2 when a temporary recession led to a surge in budget deficits and threatened to push France, Germany, Italy and Portugal over the threshold. It was ironic that this crisis should embroil Germany since it had been largely responsible for insisting on a strict and restrictive rule in the first place. Had the rule contained some counter-cyclical provisions such a development would never have caused a problem but that was not the case. Indeed breaching the rules could invoke sanctions in the form of fines equivalent to $0.5 \%$ of GDP. But these sanctions were not automatic.

Instead of accepting the discipline of their own rules, France and Germany together began a campaign for 'easing' them. As a result of their combined pressure, a recommendation by the Commission that the two countries take immediate measures to rectify the position was overruled by the finance ministers at their meeting in November 2003 (COLLINGON, 2004). In 2005 the ministers, against the misgivings of the ECB, relaxed the rules themselves in a way that allowed the ministers to take a longer-term view of budget perspectives and which permitted countries with a debt ration below 60 per cent a budget deficit of 1 per cent of gdp, but which held countries with a deficit of over 100 per cent to achieving a balanced budget or even generating a surplus (FISCHER; JONGUN; LARCH, 2006). Significantly, nothing was done to strengthen enforcement mechanisms and the new regime was repeatedly flouted by countries as Austria, Greece, Italy and Portugal. The reason was simple. Once the rules had been bent in favour of the strong, they lost the moral authority to reimpose them on the weak even if they had the inclination to do so. 
Table 3: Government Debt:GDP Ratio (\%)

\begin{tabular}{|l|l|l|l|l|l|l|l|l|l|l|}
\hline & 99 & 00 & 01 & 02 & 03 & 04 & 05 & 06 & 07 & 08 \\
\hline Austria & -2.7 & -2.9 & -4.3 & -2.9 & -3.0 & $\mathbf{- 3 . 4}$ & $\mathbf{- 5 . 9}$ & -4.1 & $\mathbf{- 3 . 1}$ & $\mathbf{- 3 . 5}$ \\
\hline Belgium & -0.6 & 0.0 & +0.4 & -0.1 & -0.1 & -0.3 & -2.7 & -0.1 & -0.3 & -1.3 \\
\hline Finland & +1.6 & +6.8 & +5.0 & +4.0 & +2.4 & +2.3 & +2.7 & +4.0 & +5.2 & +4.2 \\
\hline France & -1.8 & -1.5 & -1.5 & $\mathbf{- 3 . 1}$ & -4.1 & $\mathbf{- 3 . 6}$ & -2.9 & -2.4 & -2.7 & $\mathbf{- 3 . 3}$ \\
\hline Germany & -1.5 & 1.3 & -2.8 & $\mathbf{- 3 . 7}$ & $\mathbf{- 4 . 0}$ & $\mathbf{- 3 . 8}$ & $\mathbf{- 3 . 3}$ & -1.6 & +0.3 & +0.1 \\
\hline Greece & $\mathbf{- 3 . 1}$ & $\mathbf{- 3 . 7}$ & $\mathbf{- 4 . 5}$ & $\mathbf{- 4 . 8}$ & $\mathbf{- 5 . 6}$ & $\mathbf{- 7 . 5}$ & $\mathbf{- 5 . 2}$ & $\mathbf{- 5 . 7}$ & -6.4 & -9.8 \\
\hline Ireland & +2.7 & +4.7 & +0.9 & -0.4 & +0.4 & +1.4 & +1.6 & +2.9 & +0.1 & -7.3 \\
\hline Italy & -1.7 & -0.8 & $\mathbf{- 3 . 1}$ & -2.9 & $\mathbf{- 3 . 5}$ & $\mathbf{- 3 . 5}$ & -4.3 & $\mathbf{- 3 . 4}$ & -1.5 & -2.7 \\
\hline Luxembourg & +3.4 & +6.0 & +6.1 & +2.1 & +0.5 & -1.1 & 0.0 & +1.4 & +3.7 & +3.0 \\
\hline Netherlands & +0.4 & +2.0 & -0.2 & -2.1 & $\mathbf{- 3 . 1}$ & -1.7 & -0.3 & +0.5 & +0.2 & +0.6 \\
\hline Portugal & -2.7 & -2.9 & -4.3 & -2.9 & -3.0 & $\mathbf{- 3 . 4}$ & $\mathbf{- 5 . 9}$ & -4.1 & $\mathbf{- 3 . 1}$ & $\mathbf{- 3 . 5}$ \\
\hline Spain & -1.4 & -1.0 & -0.6 & -0.5 & -0.2 & -0.3 & +1.0 & +2.0 & +1.9 & -4.2 \\
\hline
\end{tabular}

Source: European Commission, European Economy. Statistical Annex 2011

The 'result' of fiscal prudence should have revealed itself in two 'market' mechanisms -relatively low government borrowing costs and relatively low inflation rates. Indeed both 'effects' were apparent. One almost immediate impact was a sharp reduction in the range of interest rates governments had to pay for long-term borrowing, which was in sharp contrast to the period leading up to the adoption of the Euro (EHRMANN et al, 2011). What is slightly more disturbing is why this should have been so. In economic theory markets function properly when there is transparency, shared knowledge, low transaction costs and economically rational actors. Government debt should be one of the more predictable markets. Nonetheless the rate of interest paid on the debt of a poor, debt-burdened economy renowned for its fiscal laxity (like Greece) and on that of a rich, relatively debt-light economy known for its fiscal rectitude (like Germany) was virtually identical. Few, however, remarked on the irrationality and unpredictably of capital markets. One effect was to allow countries to refinance their debts relatively cheaply, and thus removing the market penalty on persistent deficits at a time when the political sanction had also been abandoned. For the poorer economies, high government debt levels were refinanced far below those prevailing in previous decades. There was little incentive to trim excessive deficits back to the 60 percent threshold and both Germany and France (not to mention Austria, Belgium, Greece, Italy and later Portugal) allowed themselves the luxury of higher levels of sovereign debt that than stipulated in the Stability and Growth Pact. 


\section{Richard Griffiths}

Table 4: Government Debt: GDP Ratio (\%)

\begin{tabular}{|l|l|l|l|l|l|l|l|l|l|l|}
\hline & 99 & 00 & 01 & 02 & 03 & 04 & 05 & 06 & 07 & 08 \\
\hline Austria & 67.2 & 66.5 & 67.1 & 66.5 & 65.5 & 64.8 & 63.9 & 62.1 & 60.7 & 63.8 \\
\hline Belgium & 113.7 & 107.9 & 106.6 & 103.5 & 98.5 & 94.2 & 92.1 & 88.1 & 84.2 & 89.6 \\
\hline Finland & 45.7 & 43.8 & 42.5 & 41.5 & 44.5 & 44.4 & 41.7 & 39.7 & 35.2 & 34.1 \\
\hline France & 58.8 & 57.3 & 56.9 & 58.8 & 62.9 & 64.9 & 66.6 & 63.7 & 63.9 & 67.7 \\
\hline Germany & 60.9 & 59.7 & 58.8 & 60.4 & 63.9 & 65.8 & 68.0 & 67.6 & 64.9 & 66.3 \\
\hline Greece & 94.0 & 103.4 & 103.7 & 101.7 & 97.4 & 98.9 & 100.3 & 106.1 & 105.4 & 110.7 \\
\hline Ireland & 48.5 & 37.8 & 35.5 & 32.1 & 30.9 & 29.6 & 27.4 & 24.8 & 25.0 & 44.0 \\
\hline Italy & 113.7 & 109.2 & 108.8 & 105.7 & 104.4 & 103.9 & 105.9 & 106.6 & 103.6 & 106.3 \\
\hline Luxembourg & 6.4 & 6.2 & 6.3 & 6.3 & 6.1 & 6.3 & 6.1 & 6.7 & 6.7 & 13.6 \\
\hline Netherlands & 61.1 & 53.8 & 50.7 & 50.5 & 52.0 & 52.4 & 51.8 & 47.4 & 45.3 & 58.2 \\
\hline Portugal & 49.6 & 48.5 & 51.2 & 53.8 & 55.9 & 57.6 & 62.8 & 63.9 & 68.3 & 71.6 \\
\hline Spain & 62.3 & 59.3 & 55.6 & 52.5 & 48.7 & 46.2 & 43.0 & 39.6 & 36.1 & 39.8 \\
\hline
\end{tabular}

Source: European Commission, European Economy. Statistical Annex 2011

Another result of the low prevailing interest rates was to fuel asset bubbles and the growth of speculative banking practices. But surprisingly, the impact on prices was relatively mute. No country actually breached the target, when averaged over the decade. Nonetheless, some countries were persistently higher than the three lowest and that difference, although no more than 1-1.5 per cent a year led to a cumulative gap in price levels of almost twenty per cent, and that inflationary gap was measured against some of the most competitive countries in Europe. As the competitiveness of Greece, Spain and Portugal was gradually eroded, so their economic growth slowed and the capacity for workcreation was much reduced. The promise of convergence - high growth paid for by higher inflation - was turning into an ash of just higher inflation. If European demand were to slow, these weaknesses would be cruelly exposed.

Table 3: Average HICP Inflation Rate over the first decade of the Euro

\begin{tabular}{|l|l|l|l|l|l|l|}
\hline Lowest 3 & Áustria & Bélgica & Finlândia & França & Alemanha & Irlanda \\
\hline 1.77 & 1.98 & 2.18 & 1.76 & 1.91 & 1.68 & 1.96 \\
\hline Itália & Grécia & Luxemburgo & Holanda & Portugal & Espanha & \\
\hline 2.29 & 3.36 & 2.78 & 1.88 & 2.37 & 2.85 & \\
\hline
\end{tabular}

Source: CBS Webmagazine 10.1.2012 


\section{The Crisis}

Few economists had anticipated the financial crisis that swept through the world economy in 2008. The signs of asset bubbles had been apparent much earlier. The ratio of real estate prices to earnings in parts of the USA, in some Mediterranean countries (as well as in Ireland and the Netherlands) had already reached levels that would prove difficult to sustain, but an adjustment need not necessarily precipitate a collapse. Ironically, it was the fact that such adjustment was underway that precipitated the crisis as people in the USA defaulted on their housing loans. This would impact directly on those financial agencies directly involved in the housing market, and it did. The Lehman Brothers, Freddie Mac and Freddie May were soon all in financial difficulties and Lehman Brothers filed for bankruptcy on $15^{\text {th }}$ September 2008. What tilted a sectoral crisis into a truly global one was the at that Lehman Brothers had sold on the ownership of some of its mortgage assets to other banks, but in forms that made it difficult to assess the risk involved. Other banks held these poisoned assets and noone knew which banks they were and what was the degree of the exposure. Inter-bank lending, which served to lubricate the world economy, contracted virtually overnight and the impact of the resulting 'credit crunch' reverberated through the developed economies of North America and Western Europe (EICHENGREEN et al, 2009). As far as the Eurozone was concerned, attention rapidly focused on four countries, rather ungraciously known as the PIIGS - Portugal, Ireland, Italy, Greece and Spain.

Table 4. Government Debt and Deficit Data for "PIIGS" countries

\begin{tabular}{|l|l|l|l|l|l|}
\hline \multicolumn{7}{|l|}{} & Portugal & Ireland & Italy & Greece & Spain \\
\hline Government deficit & -3.5 & -7.3 & -2.7 & -9.8 & -4.2 \\
\hline 2008 & -10.1 & -14.3 & -5.4 & -15.4 & -11.1 \\
\hline 2009 & -9.1 & -32.4 & -4.6 & -10.5 & -9.2 \\
\hline 2010 & -5.9 & -10.5 & -4.0 & -9.5 & -6.3 \\
\hline 2011 & 71.6 & 44.4 & 106.3 & 110.7 & 39.8 \\
\hline Government debt & 83.0 & 65.6 & 116.1 & 127.1 & 53.3 \\
\hline 2008 & 93.0 & 96.2 & 119.0 & 142.8 & 60.1 \\
\hline 2009 & 101.7 & 112.0 & 120.3 & 157.7 & 68.1 \\
\hline 2010 &
\end{tabular}

Source: European Commission, European Economy. Statistical Annex 2012 


\section{Richard Griffiths}

Let us start with Ireland. Ireland had been almost a show-case country for the European Union. It was the "Celtic Tiger" that, with financial support from the European Union, had transformed itself from a lesser developed part of the Continent into one that had overtaken the UK in terms of per capita national income. All of its financial indicators conformed to the targets of the Stability and Growth Pact. But none of this reflected the growing instability of the private sector. Banks had overextended themselves by borrowing cheaply on international markets and fuelling a "property bubble' of impressive dimensions. Property prices had already begun to slide in 2007 , but collapsed as the credit crisis struck the country. To stem a possible run on overextended banks the government first guaranteed all bank deposits and, a year later, effectively nationalized the banks' bad debts. This was against the backdrop of a gathering recession that eroding government income and a programme of fiscal restraint. As the government's borrowing requirement ballooned and the level of sovereign debt soared, the credit lines began understandably to tighten (LANE, 2011). In November 2010, the country accepted a 'bail-out' package of $€ 67.5$ billion supplied by the IMF and the European Union (with three non-euro countries - UK, Denmark and Sweden - contributing individually) on condition that the government enact further measures to bring government spending under control.

For the purpose of this article, Italy, Portugal and Spain fall almost into the same category, though there are marked differences between them. They are all countries whose competitive positions were eroded during the years of the build-up to, and adoption of, the euro when the impact of price and inflation differentials could not be rectified by currency depreciation. Nailed to a $21^{\text {st }}$ century version of the gold-standard, economic equilibrium depended increasingly on domestic deflation, to reduce prices, or on economic reform, to increase competitiveness. When a country does neither, the foundations of economic growth become eroded and they become increasing vulnerable to the impact of cyclical downturns. In the case of Spain and Portugal, the situation was aggravated by a speculative property boom, similar to that which had characterized developments in Ireland. In these countries, too, when the bubble burst, the subsequent contraction of the construction sector led the slide into recession with rising unemployment and a burgeoning fiscal deficit. In Spain 
the impact was cushioned by the relatively low level of government debt but for Portugal the twin demands of rolling over debt and funding the current deficit stretched the confidence in the government's ability to pay (BLUNDELLWIGNALL; SLOVIK, 2011). In May 2011 the European Union the ECB and the IMF (jointly known as the Troika) contributed to a Portuguese 'bail-out' of $€ 78$ billion, conditional on new austerity and privatization measures. Italy has been caught in the back-wash of these developments. Although it has a relatively high level of debt, its repayment schedule is not tight and much of the debt is held domestically. Moreover, its current deficit levels are not out of line with those elsewhere in Western Europe. With markets jittery, there were doubts over the ability of Italy's ability to sustain these debt levels given the erosion of its competitiveness and growth potential and concern over the inability of the government to cut expenditure and introduce reforms. As the cost of borrowing edged ever higher, the Berlusconi government stepped down and was replaced by an emergency technocratic government deemed capable of enacting the necessary reforms.

We can now turn to Greece. The country entered the Euro two years after the start because the European Commission and member states were uncertain whether it could maintain the necessary discipline. They should have stayed skeptical, but as the Greek government managed to manipulate its budget deficit to a record low of 2.7 per cent in 2000 , the doubts were laid aside and Euro membership was granted. The latest revised data for the year 2000 shows a deficit a full one percentage point higher. Whatever the true figure, it was the best result Greece managed to achieve since thereafter the deficits annually crept ever upwards but initially, because the economy was still growing strongly on the back of cheap credit, not so the level of debt. Although successive Greek budgets became more profligate, from 2005 the debt levels did begin to respond. In that year, the Commission revealed systematic underreporting of deficits by the Greek government and it started proceedings against it. These persisted until 2007, but stopped short of applying sanctions (EUROPEAN COMISSION, 2005). Meanwhile, in 2006 the Greek government attempted a new approach which had to succeeded would have slashed the size of the deficit and weight of debt by a quarter. In September 2006 it suggested that the national income be raised by 25 per cent to include the (unreported) 


\section{Richard Griffiths}

'black economy'. This was rejected by Eurostat officials but they did allow an upward revision of 9.7 per cent.

The recession hit Greece hard. Competitiveness had been deteriorating and its shipping and tourism industries were particularly vulnerable to a cyclical downturn. The Greek budget forecast for 2009 was originally for a deficit of 3.7 per cent, down from the 5 per cent reported for 2008. By October of that year the two figures were revised upwards to 12.5 per cent and 7.7 per cent respectively. The European Commission's (2010) judgement was damning. While accepting that Greek statistical recording and reporting was a mess, it also suggested that figures had been deliberately manipulated for political ends. The implications were that Greek financial reporting was uncontrolled and uncontrollable. Several months later Der Spiegel (2010) revealed that Goldman Sachs had connived in the underreporting of government debt by arranging currency swaps at fictitious rates that concealed the true level of government indebtedness.

The spiraling levels of Greek indebtedness undermined any remaining confidence of markets in the ability of the government ever to redeem them. Interest rates on new Greek borrowing shot skywards and in April 2010 the government applied for a loan of $€ 45$ billion to cover its borrowing commitments for the rest of the year. A month later, after imposing savage budget cuts, and provoking a bitter public reaction, it received a bailout of $€ 110$ billion from the IMF, the ECB and the EU. By now, the impact of the recession, reinforced by the government's deflationary policy, were further undermining tax receipts. The Troika responded in October 2011 by offering a second bail-out worth $€ 130$ billion, on condition that Greece produce a convincing and effective austerity and reform programme. At the same time, it pressured private holders of Greek debt voluntarily accept a debt restructuring package involving losses of up to 70 per cent on the face value of their loans, and at the same time converting them to new longer-term loans at favourable interest. It was an all-or-nothing offer, and succeeded in reducing the level of Greek debt by $€ 105$ billion. A new technocratic government, meanwhile, committed itself to bringing the level of sovereign debt back down to 120 per cent by 2020 (most recently revised to 117 per cent) - the level at which it had stood when the crisis began. 


\section{Lessons from the Eurocrisis}

The above description of the crisis is a tidy version of events. Reality was rather different. The first problem was that Article 125 of the Maastricht treaty specifically ruled out the option of a "bail-out" for countries with public debt problems. This position designed to eliminate the danger of what economist call "moral hazard" whereby relief measures apparently condone and reinforce the tendency towards the deviant behaviour that had caused the problem in the first place. Thus as the banking crisis was undermining the stability of the financial sector in various Eurozone countries, and when markets needed reassurance, the ministers of the 27 member states had to agree the basis for any intervention. Neither the framework nor the means for intervention were in place before hand. When the means were in place, they were scarcely of the magnitude to reassure the markets. It did not take a Nobel-prize economist to figure out that the size of the 'bail-out' funds would be insufficient to resolve multiple concurrent crises. Moreover, as the disbursement of the funds was made conditional upon remedial measures being taken by the recipient, the entire operation doubled the causes of uncertainty, without ever resolving the essential question - would it ever be enough?

At present, in March 2012, the European Union has agreed to strengthen its financial governance. It increased the possibility of implementing an "excessive deficit procedure" and introduced a "reverse qualified majority voting procedure" (whereby a judgement could only be overturned by a majority against) to enable the imposition of sanctions that could amount to 0.5 per cent of GDP. A separate intergovernmental treaty would require governments to limit deficits to 0.5 per cent of GDP (one per cent if countries had a debt level of less than 60 per cent), but with escape clauses for special circumstances. These limits should be introduced into national law. Surveillance and cooperation measures were also strengthened. At the same time, the financial instruments were strengthened. In May 2010, the EU finance ministers had created a temporary funding arrangement - the European Financial Stability Facility (EFSF) with a capital commitment of $€ 780$ billion and a lending capacity of $€ 440$ billion. In December 2010, they agreed to the creation of a permanent European Stability Mechanism (ESM) with a lending capacity of $€ 500$ billion to take over from the EFSF when it elapses in July 2013. Since the EFSF has already lent $€ 192$ billion, the open question at time of writing is 


\section{Richard Griffiths}

whether to treat the ESM additional funding, raising the total to $€ 692$ billion, or not. Whatever, they decide, it will never be enough if a cataclysm does occur.

For now, the crisis has apparently subsided. Let us now briefly examine the cost and then, speculate about the future. When the crisis broke, I was in favour of the European Union maintaining its 'no bail out' stance, partly because of the moral hazard argument and partly because there was a readymade alternative in the form of the IMF. All the EU member states are individually members of the IMF and the IMF has both the mandate and the means to intervene. One argument is that the IMF might not have had the funds, but that could have been resolved by raising its capital. This need not have been difficult since the BRIC countries had wanted to do this for some time (increasing their voting power in the process) and the EU states could have contributed as well. With this resolved, the IMF could have gone into countries, bullied their governments, making itself thoroughly resented, and then left. Instead, the EU put itself into the middle of this process, despite the fact that it was not equipped for the task and that it was not a unitary actor. As a result the EU has complicated the rescue plans and heaped disapproval and resentment upon itself. This would also have been true of the IMF, but the IMF is not trying to build "an ever closer union" as the EU is pledged to do. As distrust of Brussels institutions is rising, the EU's active involvement in various austerity programmes will damage its chances of securing referenda for any future treaty changes it requires, and moving the reform agenda outside the usual democratic circuits will only increase public disenchantment. The EU may still weather the crisis, but it could be paying the political price long after the monetary costs have been absorbed and forgotten.

But has it solved the crisis? At the moment, the markets are calm, but markets are hardly a trustworthy barometer. Despite their elevation in globalisation literature to almost omnipotent and omniscient status, markets have not performed well. In currency markets, they have presided over wild swings (both overshooting and undershooting) in exchange rates and they have long ignored blatant signs of difficulties in the capacity of debt service by certain states. They are now supposed to have been reassured by the new firmness of the EU approach, a firmness which at its first test was to give a waiver from its solemn obligations to Spain. Spain had overshot its deficit in 
2011 (8.5 per cent instead of 6.0 per cent) and was given a revised target for 2012 (5.8 per cent instead of 4.4 per cent). It is good to build exceptions into legislation, but it is not good politics to begin with them. The Dutch, hitherto one of the 'best boys' in the class, has a minority government coalition in trouble over meeting the EU's criterion, and an opposition and the influential Central Planning Bureau, opposed. It may become a second country missing its obligations. And if it is not the Netherlands, there are several candidates to be next in line for special treatment.

A further problem lies in the effectiveness of the various austerity programmes. Piling deflation on economies that are already contracting usually serves to exacerbate the downward trend and could even increase the level of deficit or debt, expressed in relation to a lower GDP. The apparent immunity of deficits to the medicine prescribed may well again lead investors to question the creditworthiness of nation states, but not only them. Several countries that had experiences a credit boom in the years before the crisis also experienced inflated asset prices, which have not yet fully adjusted to the new realities. In the absence of a reappearance of sustained growth, these assets are often still lurking at inflated values on bank balance sheets. The next market attack may not be one of confidence in governments, but of confidence in banks. If, for example, housing prices do not recover in Spain, a run on Spanish banks could still occur, confronting the government with the alternatives of financial meltdown or nationalization of bank assets. This could precipitate another 'bailout', but this time on a much larger scale than any than have gone before (MCRAE, 2012). But even if we ride out these problems, we still have Greece. It surely stretches credulity to believe that a country where the tax system is inefficient and the population resentful, where the tax evader is a hero and the honest man a fool, is going to reduce its sovereign debt level to 120 per cent by 2020 and run a balanced budget every year, for the next ten-twenty years thereafter, until its level of debt reaches 60 per cent.

A final consideration lies in the fact that even if the $E U$ resolves the debt/deficit issues, we have done nothing to deal with the gap in competitiveness that has emerged. It is very difficult to press a 20 percent price differential out of the system, especially without the option of devaluation. The 'gold bloc' countries attempted this in the 1930s and failed (EICHENGREEN; IRWIN, 2010). My guess is that the Mediterranean countries, trapped within 


\section{Richard Griffiths}

the Euro and without the option of domestic protection, may find themselves left with a sound fiscal base but with a stagnant economy. The alternative of leaving the euro and adopting a new (depreciating) currency is also not an attractive option. Even should the Euro survive, for them there is no happy ending inside or outside the bloc.

\section{Conclusion}

In May 2008 The European Commission celebrated the tenth anniversary of the start of the Eurozone (not the issue of the currency) with the publication of a commemorative volume. Writing its forward, the Commissioner for Economic and Monetary Affairs trumpeted:

"A full decade after Europe's leaders took the decision to launch the euro, we have good reason to be proud of our single currency. The economic and monetary union and the euro are a major success. For its member countries, EMU has anchored macro-economic stability, increased cross border trade, financial integration and investment. For the EU as a whole, the euro is a keystone for further economic integration and a potent symbol of our growing political unity. And for the world, the euro is a major new pillar in the international monetary system and a pole of stability for the global economy."(EUROPEAN COMISSION, 2008, iii)

It is sad to reflect, now, that the design was faulty, the implementation flawed, the management lax, the crisis mishandled and that the future still remains uncertain. To push forward towards even more 'European' solutions, to see the crisis as an opportunity, would at this moment be a mistake. The public is not ready for such a move, and are unlikely to forgive (yet another) attempt to do things above their heads, if not behind their backs. For the moment, it would be a considerable achievement to hold the stability of the currency area. The Euro is easily salvageable, if not necessarily with its current membership. Once matters have settled, there will be the time to find structural solutions and to continue on the road of what, for all its shortcomings, has been one of the greatest achievements of post-war European history. And when we offer lessons to others, it may be with a little more modesty and humility that has often been the case in the past. 


\section{REFERENCES}

BOS, F. (2008) Use of National Accounts. History, Standardisation and Application in the Netherland, MPRA Paper 9387, http://mpra.ub.unimuenchen.de/9387/1/MPRA_paper_9387.pdf

BLUNDELL-WIGNALL , A. and P Slovik (2011) "A market perspective on the european sovereign debt and banking crisis". OECD Journal: Financial Market Trends, 2, 1-28

BUITER, W., G. Corsetti and N. Roubini (1993) "Excessive deficits. Sense and nonsense in the Treaty of Maastricht" Economic Policy, 8, 16, 57-100.

COLLINGON, S. (2004) "The End of the Stability and Growth Pact?" International Economics and Economic Policy, 1, 1, 15-19.

$\begin{array}{llll}\text { DER SPIEGEL, Online International } & \text { 2.8.2010 }\end{array}$ http://www.spiegel.de/international/europe/0,1518,676634,00.html

EICHEngreEN, B.; A. Mody, M. Nedeljkovic, and Lucio Sarno (2009) How the Subprime Crisis Went Global: Evidence from Bank Credit Default Swap Spreads, NBER Working Paper No. 14904.

EICHENGREEN, B and D. A. Irwin (2010) "The Slide to Protectionism in the Great Depression: Who Succumbed and Why?" Journal of Economic History, 70, 04, 871-897.

EHRMANN, M; M. FRATZSCHER, R. S. GÜRKAYNAK and E. T. SWANSON (2011) "Convergence and Anchoring of Yield Curves in the Euro Area", Review of Economics and Statistics, 93, 1, 350-364.

EUROPEAN POLICY CENTRE (2012) The Maastricht Treaty - 20 years later, Event Report dd 16.02.2102

EUROSTAT (2004) Report by Eurostat on the Revision of the Greek Government Deficits and Debt Figures, 4.11.2004

EUROPEAN COMMISSION (various), European Economy, Brussels

EUROPEAN COMMISSION (2008)TheEMU@10. Successes and Challenges after ten years of Economic and Monetary Union, Brussels.

EUROPEAN COMMISSION (2010), Report on Greek government deficit and debt statistics, 8.1.2010

FINGLETON, B (1999) "Estimates of time to economic convergence: an analysis of regions of the European Union" International Regional Science Review, 22, $1,5-34$.

FISCHER, J.; L JONGUN and M. LARCH (2006) 101 Proposals to reform the stability and Growth pact. Why so many? European economy. Economic papers. No 267, Brussels

GARRETT, G. (1993)“The Politics of Maastricht" Economy and Politics, 5, 2, 105-123

ISSING, O. (2008) The Birth of the Euro, Cambridge.

JORDAN-WAGNER, J. (1994) "A Historical Analysis of ERM realignments" Essays in Economic and Business History, 12, 31-47.

LANE, P. (2011) The Irish Crisis, CEPR Discussion Paper No. DP8287 


\section{Richard Griffiths}

LEONARDI, R. (1995) Convergence, cohesion and integration in the European Union, New York.

MCRAE, H. "Why Spain is odds-on for a bailout by the end of the year" The Independent, 29.2.2012

SIESTO, V (1987) "Concepts and Methods involved in the Last Revision of Italy's GDP" Labour, 1, 3, 181-200. 


\begin{abstract}
This article examines the European experience with economic and monetary union from three perspectives - the design, the implementation and the management of the euro - before exploring the implications of the current crisis.
\end{abstract}

\title{
KEYWORDS
}

Euro; Crisis; European Union; 


\title{
BRAZIL IN THE CURRENT WORLD ORDER
}

\author{
Amado Luiz Cervo ${ }^{1}$
}

\section{Introduction}

The Brazilian model of international insertion deepens, in the $21^{\text {st }}$ century, the alliance between State and society and raises the level of maturity. Diplomatic action, foreign policy and movement of non-state actors that pursue specific interests through their external initiatives compose the tripod of our concept of international integration. It is therefore necessary to deepen the three components of international integration, which no longer can be reduced, as imagined in the past, to diplomatic or foreign policy conduct, even if the latter adds perceptions of national interest to the former.

What has the change been to the State's functionality? After being a developmental and centralized State, after the neoliberal State that delivered the forces of economy and society to their own course without supporting them, has the state assimilated the most striking phenomenon of the last two decades, that is, the emergence of society, which manifests itself through actors and powers? How to conceptualize this new functionality?

The power instruments driven by the three components of international integration in the $21^{\text {st }}$ century constitute another intellectual challenge when it comes to understanding the subject. What is the role of integration, emerging coalitions, and old and new partnerships, not only as power instruments, but as effective ways of achieving goals?

\footnotetext{
${ }^{1}$ Professor of International Relations at the University of Brasilia. Emeritus. CNPq Senior Researcher (alcervo@unb.br).
} 
Diplomacy moves in the $21^{\text {st }}$ century based on the principle of reciprocity of benefits. In the areas of trade negotiations and international security, environmental issues and human rights, the principle of reciprocity intends to penetrate the old order, whose rules or systems were determined by the decision prevalence of advanced nations for their own benefit. The old order built up and prolonged the world of asymmetries. The principle of reciprocity of benefits postulates, in these terms, conditions to promote more equality among nations.

It is understood, therefore, why three power goals are sought by BRICS, the group which represents the interests of the developing world: establishing a new strategy of international security, promoting rules of trade and finance that aim at overcoming the gap between nations and, finally, requesting more power in global financial bodies in order to give effect to both strategies.

There is nothing more surprising for Brazil's international insertion in the $21^{\text {st }}$ century than the process of internationalization of its economy. How is it unleashed, which geographical directions does it take, and which benefits does it bring? It is observed, indeed, that the global expansion of Brazilian enterprises occurs in accelerated pace in the $21^{\text {st }}$ century and establishes a level of interdependence that allows any historian to ask: has the country finally reached its maturity in the market economy system that guides international economic relations?

The framework of analysis of the international insertion of Brazil in the $21^{\text {st }}$ century would not be objective without unraveling the limits of diplomatic action and foreign policy, which certainly affect the movement of economic agents - the most relevant to the welfare of society. Therefore, in addition to conceptualizing the Logistic State, we insist on identifying its still serious limits of efficiency.

This scheme, determined by key issues which are connected to the base of the conceptual framework that we have developed in recent decades about the international relations of Brazil, allows us to build the cognitive and explanatory argument and to promote the evaluation of results about the current Brazilian model of international insertion. 


\section{Amado Luiz Cervo}

\section{The Logistic State: a new functionality of the State}

The leaders of $21^{\text {st }}$ century become aware of the State's role when requiring political action in order to make the nation enter the global processes as an agent of the system.

The shift in the State's paradigm, that is, the change in functionality, occurs in Brazil in the medium term and for two reasons.

The old developmental State responsible for the degree of development achieved from 1930 to 1980 , especially by adding continuity and rationality to the industrialization process of the country, reaches the 1980s showing severe addictions, due to heightened introspection: high degree of protectionism in the consumer market, low productivity of industrial production systems and services, monetary instability, external indebtedness and economic stagnation. The depletion of developmentalism was noticeable.

The break that occurs with the advent of neoliberal regimes of the 1990s in Brazil and all Latin America is the result of the crisis from the previous model. Characterized by the demolition of the robust core of national economies, by the unconditional opening of the market and production systems and services, by the privatization of state-owned enterprises with the sale of its assets in favor of foreign companies, neoliberalism further deteriorated, according to ECLAC-CEPAL data, the conditions of income, employment, health and welfare of the people. Brazil was the only Latin American country showing serious hesitations over the results of neoliberal reforms. Fernando Henrique Cardoso, who led this argument, elaborated the concept of asymmetrical globalization to mean his reluctance, and opened the way for the new logistic paradigm, consolidated by the leaders of the $21^{\text {st }}$ century.

Logistic is the State that does not reduce itself to serving, as it did at the developmental time, or attend passively to market forces and hegemonic power, as it did at the time of neoliberalism. Logistic because it recovers the developmental strategic planning and serves as support and legitimization of the initiatives from other economic and social actors, to which it transfers responsibility and power.

Relations between Brazil and the United States exemplify how the logistic conduct of the State penetrates foreign policies: to create facilitation, establishing opportunities for economic and social agents to operate confidently, 
in order to achieve specific goals. Two recent meetings between the head of State of Brazil and her U.S. counterpart have shown the maturity of the Logistic State.

In March 2011, the president of Brazil, Dilma Rousseff, received in Brasilia the U.S. President, Barack Obama, in his first trip to the country. The two leaders promoted business opportunities, signing agreements to facilitate the movement of traders and investors. To this end, the Brazil-U.S. Commission on Economic and Trade Relations was created with the purpose of promoting cooperation in energy, especially oil and ethanol, since Brazil needs investments and the U.S. is interested in Brazilian pre-salt oil and the production of biofuel. The Commission will also take care of trade barriers, such as surcharges, and projects in the area of infrastructure, space cooperation, and education, among others.

During Rousseff's visit to the United States in April 2012, one was able to perceive how the independent societies function, after the emergence of Brazilian society since the 1990s. The negotiations were based on the assumption according to which States must support consistent relationships between its dynamic segments. Thus, the autonomy of foreign policy was admitted on both sides, disagreements about the NATO interventions, human rights and Cuba were not discussed, but new agreements were signed, facilitating contacts and actions in education, including the scientific and technological cooperation and exchange of professors and students of Brazilian universities with advanced centers such as MIT and Harvard, cooperation between Embraer and Boeing in business, recognition of cachaça (export grows $100 \%$ in 2012) and bourbon as genuine drinks from each country and taking the respective producers into consideration, cooperation in food security and debureaucratization of the bilateral flow of people. The functions of the States gain access to the condition of convergent pattern of conduct: removing obstacles and promoting opportunities for action by the agents of both societies in pursuit of their sectoral interests.

\section{Emergence of Society: the internal input}

The most important factor in the origin of the Logistic State is the emergence of society. It allows the functionality of the State to transit from almighty State, which trailed social actors or agents with low margin of power, autonomy, and 


\section{Amado Luiz Cervo}

initiative, to another condition in which the State transfers power and responsibility to those non-governmental actors and agents in order to promote development. The modification from one to the other functionality of the two components, society and State, passes through the neoliberal crisis of the $1990 \mathrm{~s}$, the strengthening crisis of society and reorganization of the State.

Three causalities collaborate to the consolidation of the Logistic State in the $21^{\text {st }}$ century Brazil: a) the society finds itself in advanced level of organization, with its class federations articulating, in sectors, industrialists, farmers, bankers, workers, traders, and consumers, a condition that facilitates the high level coordination function of the State guided by national interests, understood as the sum of sectoral interests; b) the political and economic stability, which suggests the association of the logic of the internal governability with the logic of international governance at the time of global interdependence; c) the comparatively advanced level of economic and social agents in terms of business organization and systemic competitiveness.

The emergence of society in Brazil is made possible in the direction that it has taken place in $21^{\text {st }}$ century due to historical legacy, on the one hand, and circumstantial changes, on the other hand.

Since the 1930s, the Getúlio Vargas incorporated to the governability, with characteristic of keeping rationality, the standard of conduct according to which the dynamic segments of society - industrialists, farmers, shop owners, bankers, workers, consumers and others - are not mutually exclusive or conflicting for the leaders and their corporate interests must be protected and promoted with balance, without discrimination. The standard of governability will discard, consequently, sectoral policies that punish a sector for the benefit of another, as occurs, for example, with the agricultural and urban sectors in other countries. The government has the responsibility to incorporate the sense of national interest, understood as equalization of interests which may conflict with each other, that is, harmonization of sectoral interests made by the promotion and control of all of them to avoid the imposition of one segment over another. Thus, the internal and external policies make effective the notion of a higher national interest, something that, in Brazil, explains the harmony between State and society, which has established itself and stood over governments, political parties, and regimes. 
The circumstantial element which also explains the strengthening of society in the $21^{\text {st }}$ century is the neoliberal experience of the last decade of the previous century, characterized by hesitation, self-criticism and correction of directions while in course. That is, leveling of the degree of openness and reforms to the degree of adaptability of economic forces and social organization. This measurement allows the association of the historical legacy mentioned before to the contribution of positive factors of neoliberalism.

\section{Instrumentation of integration, power coalitions and partnerships: the external input}

Certain systemic conditions of international order in the $21^{\text {st }}$ century favor the emergence of Brazil on the international scene: strengthening of economic interdependence among nations, weakening of multilateralism and integration processes, strengthening of bilateralism and autonomy of the national States, and finally the crisis in the United States, Europe and Japan. On the other hand, certain difficulties arising from this crisis, such as the valuation of traditional currencies, the devaluation of the Chinese currency, the distortion of competition caused by such manipulations on the currency, surplus in industrial production in developed countries due to the drop in consumption, among others, are factors which affect interests and the rise of Brazil.

A readaptation of foreign strategies is required by those circumstances. We will now examine some aspects regarding integration, the formation of emerging coalitions and bilateral partnerships.

The formation of blocs remains a trend in international relations in the $21^{\text {st }}$ century, without, however, expressing the dynamism of the 1990s. Two examples illustrate this inflection in the integration process.

Firstly, a slower pace in the European Union is observed. The bloc gives up the Constitution, rejected by plebiscites in 2005, and eventually replaces it by the Treaty of Lisbon, which also does not see the unanimity of its 27 members. Secondly, in South America, if the governments achieve remarkable results that improve the economic and social conditions exacerbated by neoliberalism, the so-called social inclusion, they do so through introspective solutions, focusing on national projects that ignore integration. These governments design, in addition, different models of international integration. Again, some governments do not understand integration as an efficient strategy 


\section{Amado Luiz Cervo}

to overcome their own difficulties. Under these conditions, Brazilian foreign policy, of strong integrationist character, goes through a concrete adaptation: utilizes integration processes, seen before as a kind of end in itself, as means to establish or consolidate the cooperation and power network in the South, starting from South America and progressing to alliances with other regions in order to perform as a globalist country.

A dilemma arises in the midst of the international insertion of Brazil: balancing its integration and regional development project, the most consistent of South America, with its claim of an emerging power with global reach, the most feasible in South America. It is true that this dilemma was administered with balance both by President Fernando Henrique Cardoso, in the 1990s, and by his successor, Luiz Inácio Lula da Silva in the following decade. Both pushed very hard, with support from national sectoral leadership, to lead the nation in these two lines of external action, while Dilma Rousseff, who replaced President Lula in 2011, leans toward the construction of global power.

The end point of this dilemma suggests, finally, that government and society are more likely to act on the global stage with the Brazilian mark rather than with Mercosur or UNASUR marks, even though hesitation prevailed in this field earlier. This inflection certainly does not mean the renunciation of regional integration, but the recognition that the globalist strategy acquires increasing relevance to the Brazilian model of international insertion. We would dare to advance two explanations to this inflection in favor of global: the problems caused by neighboring countries, on the one hand, and the perception that global instances contribute in a more concrete and objective way to the emergence of Brazil on the international scene than regional bodies.

The financial and economic crisis triggered in 2007 in central countries served as a circumstantial reason to strengthen the South American integration. In August 2011, at the meeting of 12 UNASUR finance ministers in Buenos Aires, Guido Mantega, the Brazilian minister, made a strong appeal to the convergence of UNASUR members in favor of regional growth. He proposed the creation of South American defense mechanisms and regional trade promotion, as well as the extension of credit, taking the fiscal strength of countries as formulas to mitigate the negative effects of the crisis. 
The regional South American integration evolves, however, from high priority to low priority in Brazil's international action strategy during the first decade of this century. Indeed, since Mercosur and UNASUR, the making of a global network rises as national purpose. Two powerful action tools are in the service of the globalist purpose. On the one hand, the reciprocal multilateralism, driven by diplomacy, intended to exercise the alleged leadership through global negotiations to strengthen, or at least allow to show, the national power. On the other hand, the internationalization of Brazilian enterprises, the outward expansion of investment and domestic business, stimulated by Lula's personal interest, which triggers the Logistic State, and driven by favorable reaction from the business, reaches all corners of the planet. The global network sits under the political and economic aspects in South America, where it takes root and grows stronger and then extends to the world. The change in perspective, though subtle, is clear: the natural place in Brazil is no longer South America, as the reality seemed to suggest earlier, but the world.

The institutionalization of BRICS happened in 2007, largely through efforts by the Brazilian government, interested in forming a bloc of developing countries. It was composed of Brazil, Russia, India and China, and later admitting South Africa. For the founders, two goals moved the bloc: facilitate and strengthen relationships between members and coordinate positions on international relations in the global sphere. The first line of action was intended to promote national interests of the economic sectors involved in transactions with the outside, but the second was intended to influence on the parameters of international order. Designed as an informal bloc, the BRICS group has, as its larger decisive instance, the summits convened regularly. We examined the latest two held in China and India.

The summit held in Sanya, China, in April 2011, the third of the series, incorporated South Africa as a new member of the group. On the agenda of the meeting, three issues occupied the leaders: measures to promote the use of local currencies in trade between the countries of the group were discussed; other measures to control prices of agricultural commodities; finally, the possibility of reaching a common position on the NATO intervention in Libya. That is, their own interests and global security.

The summit on China accounted for a large discussion forum of questions about the present international order. The demands of the emerging 


\section{Amado Luiz Cervo}

powers put on alert the powers that traditionally exercised control over the global order in their favor. Indeed, the final declaration proposed the reform of the United Nations and its Security Council, especially because the Council approved of the use of force by NATO in Libya. The international strategy of security conducted by the United States since the Second World War, with European support and backing of the UN, strategy driven by the use of violence of the sanction or intervention, is confronted for the first time, clearly, by a group of countries on the international scene. The BRICS propose to replace the strategy of violence that has subjected itself to international security by the strategy of peaceful negotiated settlement of conflicts, whether internal, regional or global.

Two other aspects of the international order show the penetration of the emerging countries in tracing their parameters to be considered by the powers which exercised almost absolute control over the order: the demand for greater participation in the management of multilateral economic bodies and better regulation of the international financial system, delivered in recent decades to the excess of freedom, cause of speculation, imbalances and the international crisis itself coming from the center.

The fourth summit of the BRICS held in New Delhi in late March 2012, reinforced the themes of the previous summit in direction to the transformation of international order, but the two perspectives of action of the group remained, considering also the realization of direct interests of its members in relations inside the bloc. Under this last aspect, it was discussed the creation of a development bank of the group, measures to promote trade and finance in local currency, as well as to combat protectionism. At a global level, there was a push for the formulation of clearer and more specific positions about the challenges of international security as a strategy of negotiated solutions, as well as a greater share of the emerging institutions of economic and financial governance.

A great victory had already been reached in the field of global security: in the Security Council, Russia and China had vetoed the use of force on Syria, after what happened in Libya. But the BRICS become relevant to the management of all international action in the Near East, not only by blocking the escalation of violence under the auspices of the Western NATO, especially 
in the case of Syria, but also warning its leaders to turn down the rhetoric of violence against the Iranian nuclear program.

What is the importance of BRICS to the international insertion of Brazil? Two observations may help to understand the issue.

One line of argumentation tends to diminish the importance of BRICS in the international insertion of Brazil. It is, according to this reasoning, a bloc with great heterogeneity regarding distribution of income, the military capabilities, the size of national wealth, the domestic demand, the degree of development as well as the ambition to play an important role on the international scene. The heterogeneity, however, is a characteristic of all blocs resulting from integration processes in recent decades. Additionally, the club of nations constituted in decision-making forums hold innocuous and of little practical effect meetings, especially when the agenda involves varied and oversized issues - that was the case in the last two summits of the BRICS. If so, however, the old G8, for example, would not have influenced the delineation of the international order, as it effectively did during the long period of its operation.

Another line of argumentation tends, however, to emphasize the role of BRICS in the international insertion of Brazil as a nation capable of influencing the transformation of the international order and promoting the interests of developing countries. The coordination of the group has produced, in fact, positive results to meet the demands of individual members. In 2011, for example, China surpassed the United States and reached the condition of Brazil's first trade partner, while the trade inside the bloc is also growing and economic relations are strengthened through various mechanisms of cooperation and direct investment enterprise. Because this is a recent group, its emergence on the international stage is delineated with the natural learning processes of integration. The willingness to continue and to build political understanding is common. Two results are already apparent: the change in the course of international security strategy and the redistribution of power in international financial governance bodies. In short, Brazil has found a seat among the great powers, engages in the transformation of the order gradually submitting it to paths correction, that is, the transition from the asymmetry to equality among nations. All of this has happened under the auspices of the traditional national interest, now of a globalist country, to be defended and promoted. 


\section{Amado Luiz Cervo}

Beside the instrumentalization of the integration process and the formation of coalitions of power, the partnerships between Brazil and other nations or other regions constitute the third factor, with more prominent historical character, strengthening, from abroad, the country's emergence on the international scene.

It was assumed that globalization and the weakening of the State would lead to the decline of bilateralism in current international relations. It was, however, just a frustrated expectation of interpreters of international order imbued with neoliberal convictions. Bilateralism presents itself as a trend that grows stronger in today's world. The University of Brasilia, the dynamic center of studies and publications about various aspects of international integration of the country in recent years, promoted the publication of two collections of books, with over twenty titles released by 2012, mainly focusing on the study of strategic partnerships, understood as the contribution of one to the national formation of the other. The studies published by Editora Juruá from Curitiba and Editora Fino Traço from Belo Horizonte focus on the historical and current partnerships considered relevant to national development and international rise.

Among the interpenetration factors of such partnerships, there is in first place the economic one, especially the flow of capital, technologies, and projects, because of their impact on the welfare of the population. Other factors act alongside: the influence on the ethnic composition, the cultural profile, the political philosophy, as well as on the establishment of institutional framework and on the same standards of international conduct. As a new country, Brazil tends to be more of a receiver than a provider of partnership factors. Historically, it maintained the continuity of strategy creation and consolidation of useful partnerships to security and economic development. People in power followed, since the dawn of the $20^{\text {th }}$ century, the advice of the patron of its diplomacy, the Baron of Rio Branco: peaceful nation is the nation that can have numerous and good partners, primarily the hegemonic powers, global or regional.

Among the oldest partnerships, some faded with time, as the nexus between Brazil and England in the 19th century. The partnership between Brazil and the United States came to replace it in the $20^{\text {th }}$ century, 
consolidating that axis of relations as the most relevant to the national formation, never depreciated by governments or political regimes_to this day. The duration of this partnership can be only compared with the one between Brazil and Argentina.

Right after the partnership between Brazil and the United States, there is a descending list of the countries which traditionally linked the most Brazil and the rest of the world: Germany, Japan, Italy, Great Britain, the Netherlands, Switzerland and Sweden, among others. However, other partnerships emerge, like the ones established with Portugal and Spain, for example, but nothing affects the international insertion of Brazil so much as the recent partnership with China, which, although limited mainly to the commercial dimension, has reinforced in recent years with bilateral investments and political understanding.

The different regions also feed Brazilian strategy of making partnerships. In this sense, there are partnerships on their way between Brazil and the European Union, Africa and Asia, the latter one being more diffuse.

The limit imposed on the interdependence gestated within partnerships is created by the decision-making autonomy. It is a dilemma, especially when it comes to partnerships with hegemonic powers. Without decision-making autonomy, it was understood in Brazil, the expected benefits of the partnership do not happen; development and safety first.

It is concluded, therefore, that Brazil's international partnerships contribute not only to its national formation, that is, its economic, social and human development, but also to the realization of interests through foreign action, or even to its international projection. Instrumentalization of integration, power coalitions and partnerships add up effects that are presented, finally, as external inputs that explain the intensity of the country's international emergency.

\section{Multilateralism: the principle of reciprocity of benefits}

Since the creation of the first G20, the developing nations trade negotiations bloc, during the WTO Conference in Cancun in 2003, multilateralism of reciprocity has become an operational concept in Brazilian foreign policy. From trade negotiations, the most relevant for multilateral negotiations apart from security, are all dimensions of international order framed in the concept of 


\section{Amado Luiz Cervo}

multilateralism of reciprocity: the economy, trade, security, environmental issues, health and human rights. Reciprocity is established when the rules of the multilateral order benefit all nations. Consequently, it happens when an order that benefits the most advanced nations - thus keeping or extending asymmetries - is kept away.

The assumptions of multilateralism of reciprocity are two: the need for rules for the international order that without which the power disparity in favor of the great powers will prevail, and the joint development of these rules to ensure reciprocal effects in order not to realize interests of some in detriment of others.

Multilateralism of reciprocity eliminates two theoretical utopias to understand the foreign policy of Brazil: the hegemonic stability and the necessary link between foreign policy and political regime. As proclaimed by international relations theory formulated in Anglo-Saxon societies, the hegemonic stability displays as much fundament, according to Bertrand Badie, AS the hegemonic instability does. The financial and economic crisis has convinced the reader of that since 2007 . The nexus between political regime and foreign policy is such that, depending on the teaching of the history of international relations, regardless of the nature of the regime, a State may contribute to either international reciprocity or international asymmetry.

Advanced by the operational concept of multilateralism of reciprocity, the Brazilian foreign policy unfolds in five different lines of action: a) for the rules of international economy, it posits the end of the old G8 and its replacement by the financial G20, the first multilateral decision-making forum that brings together advanced and emerging countries; b) in the international trade sphere, in face of a subtle distortion promoted by developed countries, Brazilian diplomacy is defeated when the global agreement to be negotiated within the WTO is replaced by the Free Trade Agreement, which perpetuates the old order; c) in the field of international security, it looks for the replacement of the strategy of violence maintained by the NATO by the strategy of negotiated settlement of conflicts conceived within the BRICS; d) in terms of the environment, Brazil's position evolves from victim to coresponsible; e) finally, about human rights, the Brazilian diplomatic action 
unmasks the praxis of clash of civilizations or ideologies and requires universal respect by all governments.

Some results were achieved by the multilateral negotiation by the multilateralism of reciprocity in these action fronts, results that have changed the international order. A good investigation exercise would be to measure them. The most meager effect, however, seems to be in the field of international trade, whose rules remain outdated and inefficient. For Brazil, a challenge that the new administration of Dilma Rousseff should deal with is: in face of failure, which is the best trade policy for the country? To keep pursuing the world agreement in accordance with reciprocity, which seems unattainable, or to tame THE nature of the bilateral free trade? The temptation to put the second option in action applies, of course, especially when the Secretary of State Hilary Clinton, visiting Brasilia in April 2012, proposed to President Rousseff the bilateral trade agreement between Brazil and the United States.

\section{The three power strategies drawn by the BRICS}

The transformation of the international order, whose orders were drawn by the advanced nations from the Second World War to the beginning of the $21^{\text {st }}$ century, is the essential goal of the BRICS, the reason for its existence as a coalition of power. This desired transformation animates the summits of the group and is noticeable in three spheres. Such analysis, regarding the performance of the BRICS and Brazil's position within the core of the coalition, must be then organized and condensed.

As the group is supposed to represent the interests of developing countries in their attempt to internally promote social inclusion, the order should serve to internationally promote the equality among nations. This is not about ideology, rhetoric or utopia, but the specific mechanisms that differ from the image of those who kicked the ladder after having reached the top of the welfare system in domestic and international market economy.

The international security also requires a strategic shift in its management to move from mechanisms that use force, such as sanction and intervention, to negotiated solutions of conflicts. All nations, for example, have the right of access to nuclear technology for economic and peaceful use, not permitting that to be a privilege of few. The negotiation, once again, should be included as a guarantee of security. Interventions based on privilege, such as 


\section{Amado Luiz Cervo}

the ones that possibly would come from Western threats to Iran, infringe the vision of international security of the BRICS.

As the financial G20 constitutes another informal forum, the BRICS claim, for the emerging countries, more representation in multilateral agencies which exercise the effective decision-making power on international finance, such as the World Bank and IMF. They use their huge currency reserves, the Sovereign Wealth Funds, which are passed on to others or not, as they obtain greater representation and decision-making power with the aforementioned bodies, through reform of quota and voting and elimination of traditional guidance that may limit the autonomy of national policies in fiscal and financial areas. International inclusion and international security depend, in the BRICS view, on economic power, and that is why the three action strategies are programmed simultaneously.

\section{Internationalization: systemic maturity of the Brazilian economy}

In the $21^{\text {st }}$ century, the most important condition for the rise of Brazil as a globalist country is enabled, that is, there is a definite step toward systemic maturity. The internationalization of the Brazilian economy only becomes viable, however, with the contribution of society rather than that of the State, which, in turn, adapts and takes the functionality of the Logistic State. We link the elements of our reasoning: the Logistic State, the emergency of society, instrumentalization and strengthening of national power, and systemic maturity.

The outward expansion of the Brazilian companies becomes a goal of the State and the society. It consists of forming strong companies with the ability to establish and compete on a global scale. The conditions to unlock the internationalization process were encouraged by Presidents Cardoso, who privatized in the 1990s, and Lula, who conglomerated shortly after. The two phases, internal business strengthening and external expansion, had the support and enthusiastic involvement of the business people and strong financial institutions of the State, as the Brazilian Development Bank (BNDES) and Bank of Brazil.

After a timid start in previous years, the internationalization of the Brazilian economy accelerates the pace after 2005. The Brazilian direct 
investment abroad has shown ever since an average growth of $14 \%$ per year. In some years, it has exceeded the foreign direct investment in Brazil. The movement of Brazilian enterprises follows the emerging countries: they held about $5 \%$ of direct investments abroad in 1990 and over $20 \%$ in 2007 . In this particular year, consolidating US\$ 108 billion, Brazil became the second foreign investor among emerging nations and the in following year, 2008, this amount reached US $\$ 149$ billion, year in which the foreign investments in Brazil totaled US\$ 34.6 billion, a growth of $100 \%$ over the previous year. The upward trend is also observed in the amount of international reserves in Brazil, which increased from US\$ 200 billion in late 2008 to US\$ 370 billion in April 2012. After having given the country an investment grade by credit rating agencies, reserves and external flows of investment keep a steady growth trend, which also is explained in the expected profitability of investment from rich countries in emerging markets during the economic crisis that has gripped the former first world.

The geographical allocation of Brazilian direct investments abroad in 2006 moves, roughly, from the neighboring area to the world: USA, Canada, Africa and Europe. Large groups, such as Vale do Rio Doce and Petrobras, lead the trend, followed by Gerdau, Embraer, Odebrecht, Itaú, Braskem, Votorantim, Camargo Correia, AmBev, and WEG, among others. The expertise of the groups indicates that Brazilian companies

operate abroad in various fields such as mining, prospecting, metallurgy, industry and technology. The starting point in March 2006 can be explained because of barriers in Bolivia and later in other neighboring countries which curtailed investors' expectations. These are difficulties created by legal and political attitudes in the region. Between 2001 and 2008, Argentina went from $15 \%$ to $9 \%$; between 2001 and 2010 , the United States, which has become the main destination, went from $13 \%$ to $37 \%$ of the total Brazilian FDI worldwide. Moreover, in late 2011, Brazil became the sixth largest foreign investor in Europe, spending US\$ 80 billion, although the superiority of European investments in Brazil, US\$ 180 billion, still remains. This year, Brazilian investments in Europe and European investments in Brazil rose above the sum of identical flows pertaining to China, Russia and India, indicating the high comparative degree of internationalization of the Brazilian economy among emerging economies. 


\section{Amado Luiz Cervo}

Analysts from the Getulio Vargas Foundation observed another geographic reorientation of the internationalization of the Brazilian economy by 2010: the Chinese nexus. Driven by trade in previous years, this nexus has incorporated, finally, the expected flow of Chinese investment in Brazil.

In fact, Brazil and China move from the United States toward autonomy of movement, both bilaterally and globally. The new round of bilateral trade and investment had its momentum in 2010 and was guided by self-interest. The Brazil-China Business Council noted, in 2011, a change in quality and quantity in the ongoing bilateral economic exchanges. The trade balance went from US\$ 9 billion in 2004 to US\$56 billion, seven years later. It expanded $52 \%$ in 2009-2010, when China became a major trading partner of Brazil. In 2010, Chinese investments erupted. That is, the bilateral economic relationship entered a new phase and showed a rapid pace.

The motivations of entrepreneurs who invest abroad are varied: the valued currency advises to buy share of multinationals; the opening of branches, the association or acquisition of other companies favor raising funds abroad; technological development and the increase of the productivity to the global systemic level are also expected effects; finally with overseas operations, the companies intend to boost exports of higher quality. The best of all reasons, however, is to increase business productivity, which the penetration in the productive chains of the global networks offers.

Two examples, chosen at random, illustrate these positive results of the globalization of the Brazilian economy: Embraer and WEG. Privatized in 1994, with technological knowledge accumulated by the previous two centers (the Brazilian Aeronautical Center and the Institute of Aeronautical Technology) the Brazilian Aeronautics Company (Embraer) turned to the global market, added new innovation processes, established the interdependence with its business partnerships, provided its cash and specialized in order to compete. Years later, it became the third manufacturer of regional jets in the world and its products have come to occupy first place on the list of Brazilian exports. In 2012 , it has won the bid to provide the Super Tucano combat aircraft to the U.S. Air Force, a real seal of approval to move into other markets if the deal is concluded. 
An industrial company specializing in the manufacture of motors and other electrical equipment, WEG, from Jaraguá do Sul in Santa Catarina, is present in a hundred countries for technical assistance and in key countries with its factories: in Mexico, seeking the NAFTA market, and in Portugal, aiming at the European Union.

\section{Limitations of the Logistic State}

The new functionality of the Logistic State is certainly evident in driving the national economy to the level of global interdependence that moves toward maturity. The Brazilian Logistic State does not reach, however, the full effects which are presumably expected.

Three factors limit the efficiency of the Logistic State in Brazil. Firstly, the low innovation. It results from the deficient education, the lack of technological research centers such as those that explain the creation of Embraer, and the lack of technical preparation for the labor force. How to understand, in these circumstances, the current program of thousands of scholarships to be awarded to graduate students abroad and the lack of investment in research centers, whose embryos are located in universities or institutes of the country? Secondly, the low competitiveness of production and service systems, due to the low innovation, of course, but also the ineffective infrastructure, expensive energy, bureaucratic discretion, taxes, bank interest and high exchange rates. The third major factor limiting the efficiency of the Logistic State in Brazil is the operation of the coalition government. This political model, which subjects the distribution of public office to the support of the government party's coalition, compromises the nature of the State by shifting the governance, from efficiency to the partisan or personal advantage, and by opening the channel of corruption.

The heavy burden of State's inefficiency reduces the systemic competitiveness. Associated with some degree of aversion from entrepreneurs to competitiveness risk, inefficiency explains, besides the limitations of the Logistic State described above, the decline of industry, from 30\% of the GDP in the $20^{\text {th }}$ century to $15 \%$ in 2011 , according to calculations by the Brazilian Institute of Geography and Statistics.

The own functions and limitations of the Logistic State put itself in opposition to the neo-developmentalism State, whose concept orient Brazilian 


\section{Amado Luiz Cervo}

strategies in the $21^{\text {st }}$ century - or so some economists, like Bresser Pereira, mistakenly assume.

The components of the Logistic State are: multilateralism, reciprocity, economic internationalization, opening of the consumption market as well as of production and services systems, monetary stability and strong currency, development agencies, internal and external financial balance, the rise of society and the reduction of State, advanced social organization, high global systemic competitiveness. In short, interdependent insertion into the mature capitalism, as Brazil being the prototype of this model in South America.

The components of neo-developmentalism are: re-nationalization, protectionism of the consumer market, monetary instability and a weak currency, external financial imbalance, economic introspection without internationalization, asymmetry or structural dependence on the developed nations, oscillations of internal and external strategies, being Argentina the prototype of such model.

In common, both paradigms of the State run programs of social inclusion and achieve results in this area, which may confuse some economists in the use of concepts.

\section{Conclusion}

The international relations of Brazil in the $21^{\text {st }}$ century are guided by two general objectives: the realization of national interests and the contribution to the reform of the international order.

The assumptions that support the external action comprise, firstly, ideas and values. The ones in power reveal the conviction that the country should play a relevant role internationally and such conviction results in the national plan, to be assimilated by social leaders. The ideas that generate such plan are based on internal cultural base. The multilateralism of reciprocity, whereby the benefits of international order should spread over all nations, promote equality and mitigate asymmetries between them. The multilateral diplomatic negotiations are intended, according to this concept, to produce rules related to trade, finance and environmental issues which benefit all, especially the victim nations of asymmetric globalization. The universalism of international politics affects, on the other hand, human rights: to be respected 
by all, big, small and medium powers, and never to be put in the service of particular ideologies and cultures, as it has been occurring. The coexistence of differences, in other words, induces the dismantling of the clash of civilizations and of hegemonic stability, which are theories and practices put at the service of great powers.

The means of action aggregated to the foreign relations of the country in the last two decades were both the new functionality of the State, which we call the Logistic State, and the emergence of society, to whose non-state actors the State transfers this new power and responsibility regarding the external goals and the realization of national interest.

As nothing is achieved without power in international relations, along with the invention of a new nexus between State and society, the national power was also strengthened through external inputs. Regional integration in the $21^{\text {st }}$ century acquires instrumental character in this sense, no longer being an end in itself and going from high priority to low priority, without sacrificing the convenient political understanding with the neighboring region. The emerging coalitions, UNASUR, BRICS, and IBSA, among the most relevant, are responsible for important contribution of power. No less important, however, are the traditional partnerships, such as the United States, Germany, Argentina, Italy, Japan, France, Britain, and the new ones, such as Portugal, Spain, and China, among others. The partnerships extend the country's international relations network to the entire planet and reinforce its ability to expand beneficial ties.

The most relevant result to the national interest of this coupled strategy between the Logistic State and society takes shape in the internationalization of the Brazilian economy. Responding positively to the challenge of globalization, the country has achieved in the $21^{\text {st }}$ century the level of economic interdependence maturity typically experienced by advanced nations, seeking the benefits of operating in the global systemic productivity conditions.

Efficiency limits, however, keep conditioning the State and nongovernmental actors and shortening results. Business people not committed enough to technological innovation and a state full of managerial mishaps; adding up the inefficiency of both, the country is faced with low relative competitiveness due to poor infrastructure, shortage of investment in 


\section{Amado Luiz Cervo}

technology centers, appreciated interest and exchange rates, exorbitant taxes, among other factors. It lacks, moreover, an industrial strategy adapted to the new situation and even foreign trade policy, after the failure of multilateralism in this field. There is a long road ahead.

\section{REFERENCES}

ALMEIDA, Paulo Roberto de. Relações internacionais e política externa do Brasil. Rio de Janeiro: LTC, 2012.

BADIE, Bertrand. L'Impuissane de la puissance: essai sur les nouvelles relations internationales. Paris: Fayard, 2004.

BARROS, Octavio de \& Giambiagi, Fábio (orgs.). Brasil globalizado: o Brasil em um mundo surpreendente. Rio de Janeiro: Elsevier, 2008.

BERNAL-MEZZA, Raúl. América Latina en el mundo: el pensamiento latinoamericano y la teoría de relaciones internacionales. Buenos Aires: Nuevohacer, 2005.

BRASIL, Ministério das Relações Exteriores. Política Externa Brasileira, II. Brasília: Funag, 2007. Idem, Resenha de Política Exterior do Brasil, n. 96 e 97, 2005.

BRASIL, Ministério das Relações Exteriores O G-20 e a OMC: textos, comunicados e documentos. Brasília: Funag, 2007.

BRESSER PEREIRA, L. C. From old to new developmentalism in Latin America. In: Ocampo, J. A. \& Ross, J. (Eds.). Handbook os Latin America Economics. Oxford: Oxford University Press, 2011, p. 108-129.

CERVO, Amado Luiz. Inserção internacional: formação dos conceitos brasileiros. São Paulo: Saraiva, 2008.

CERVO, Amado Luiz e Bueno, Clodoaldo. História da política exterior do Brasil. Brasília: EdUnB, 2011 (4ª Edição).

CERVO, Amado Luiz. Relações internacionais da América Latina: velhos e novos paradigmas. São Paulo: Saraiva, 2007.

DUPAS, Gilberto. Atores e poderes na nova ordem global: assimetrias, instabilidades e imperativos de legitimação. São Paulo: UNRSP, 2005.

FLEMES, Daniel. O Brasil na iniciativa BRIC: soft balancing numa ordem global em mudança? Revista Brasileira de Política Internacional, n. 53 (1), p. 141-156, 2010.

GARCIA, Eugênio Vargas (org.). Diplomacia brasileira e política exterior: documentos históricos (1492-2008). Rio de Janeiro: Contraponto, 2008.

LIMA, Maria Regina Soares de \& Hirst, Monica (orgs.). Brasil, Índia e África do Sul: desafios e oportunidades para novas parcerias. São Paulo: Paz e Terra, 2009

MARTINEZ, Maria Regina Estevez. A globalização da indústria aeronáutica - o caso da Embraer. Brasília: Universidade de Brasília, Tese de doutorado, 2007. 
RAPOPORT, Mario. Historia Económica, Política y Social de la Argentina. Buenos Aires: Ariel, 2006.

ROLLAND, Denis \& Lessa, Antônio Carlos (Eds.). Relations internationales du Brésil: les chemins de la puissance. Paris: L'Harmattan , 2010, 2 vol.

SILVA, André Luiz Reis da. Do otimismo liberal à globalização assimétrica. Curitiba: Juruá, 2009.

SANTOS, Sergio Caballero. Brasil y la región: una potencia emergente y la integración regional sudamericana. Revista Brasileira de Política Internacional, 54 (2), p. 158-172, 2011.

VISENTINI, Paulo Fagundes. As relações diplomáticas da Ásia. Belo Horizonte: Fino Traço, 2011.

The main websites used in this article belong to the following institutions and offer statistic data and analysis: Ministry of External Relations; University of Brasília (Mundorama, Cena Internacional, Meridiano 47); University of São Paulo (Carta Internacional, Contato); Rio de Janeiro Research Institute (Observatório Político SulAmericano); Brazil-China Business Council; International Defense and Security Study Group (GEDES); Brazilian Institute of Geography and Statistics (IBGE); Central Bank of Brazil; Pontifical Catholic University of Rio de Janeiro (BRICS Policy Center); Getúlio Vargas Foundation (The Brazilian Economy); Juruá Publisher; Fino Traço Publisher. The newspapers Valor Econômico and $\mathrm{O}$ Estado de S. Paulo were also consulted. 


\title{
Amado Luiz Cervo
}

\begin{abstract}
International insertion of Brazil in the $21^{\text {st }}$ century is driven by new functionality of the State, which we call the Logistic State, in close cooperation with non-state actors that have been strengthened since the 1990s due to the emergence of society. Concepts, values and purposes are internal assumptions that are associated with reinforcement of power derived from the integration of emerging coalitions and bilateral partnerships. The most relevant result leading to maturity of international integration comes from the internationalization of the Brazilian economy. There are, however, barriers in State and in society which limit the effectiveness of external action.
\end{abstract}

\section{PALAVRAS-CHAVE}

Logistic State; World Order; Multilateralism; 


\section{NEO-DEVELOPMENTALISM AND THE SEARCH OF A NEW INTERNATIONAL INSERTION ${ }^{1}$}

\section{Giorgio Romano Schutte ${ }^{2}$}

\section{Introduction}

One of recent years' great innovations was the strength with which the Brazilian government articulated for the country to attain a leading role in the international arena. The government and many social sectors had a clear perception that the project on sustainability should also be implemented, with equity and social inclusion, in Brazil's foreign policy. The reasons are, firstly, because world's imbalances favor neither Brazil's nor the other developing nations' progress. Nations, in fact, which Brazil has begun to discuss with. Secondly, there has grown the perception that Brazil, according to President Luiz Inácio Lula da Silva, plays a role inferior to its true potential in the international arena. It is, after all, the fifth largest country in population and territory, and on the way to becoming the fifth largest gross domestic product (GDP) in the world; so, it is expected the country should take an appropriate, leading role in actively and creatively changing the world power's configuration. Such realization led him, under a deeply diplomatic presidency, to spend more than an eighth of his two presidential mandates (2003-2010) abroad $^{3}$.

${ }^{1}$ Article published as Discussion Paper 1732 of the Institute of Applied Economic Research (IPEA).

${ }^{2}$ Dr. Giorgio Romano Schutte, Coordinator of International Relations at the Federal University of ABC (UFABC).

3 According to the compilation of the NGO Open Accounts, the president was 470 days on official travel outside the country. 
This paper shows the capacity to react and articulate around the financial global crisis of 2008 as a turning point. From that moment on, the world began to see Brazil in a different way, and to recognize its strategic resources, such as the new oil reserves, its environment's richness, and its singular capacity to expand its food production. This new relationship level and international participation sought since 2003 have gained, then, new meaning.

My work is divided into eight sections, including introduction and final considerations. In the following sections, I will analyze the strategy behind a foreign policy that is more constructive and that is more linked to efforts on readjusting development with growth and equity in the national sphere. In the sixth section, my approach focuses on the impact that the financial crisis of 2008 caused on Brazil's international participation. The seventh section presents the basis for projecting future scenarios and strategies.

\section{Reaffirmation of autonomy}

The search to improve Brazil's position within the hierarchy of international relations is linked to developmental strategies in the national sphere. Along with the formulation of a socio-economic neo-developmental policy, discussions on the complex relation between dependency and development also resurfaced ${ }^{4}$. In his analysis of developmental conventions of today's Brazil, Erber (2010: 28) argues that the search for a new "national project on development," announced during President Luiz Inácio Lula da Silva's inaugural speech at Congress, resulted in the articulation of a "neo-developmentalist convention." Among the five pillars that justify, according to the author, this term, is an independent foreign policy that

... favors relationships with other developing countries whether they're in Latin America, or are part of the BrazilRussia-India-China group (BRIC) - and seeks to reinforce Brazil's role as a leading player in changing the world's institutional structure (ibidem: 29).

${ }^{4}$ See this debate about the classic by Fernando Henrique Cardoso and Enzo Faletto (2004). 


\section{Giorgio Romano Schutte}

The same premise that has placed the government in a leading role in bringing progress - mobilizing and re-articulating state-owned enterprises and public banks - also guided a new search for the country's inclusion in the international arena, which should work in tune with national development; while, in turn, national development ensures more resources and credibility to expand Brazil's international presence. As President Luiz Inácio Lula da Silva said on his inaugural address in 2003: "In my presidency, a more humanistic perspective will guide Brazil's diplomatic action, and it will be, above all, a tool for national development."

We are then able to draw a parallel with the independent foreign policy associated with San Tiago Dantes in João Goulart's government, when there was an attempt at international networking with other developing countries to change the institutions' multilateral framework in favor of expanding developmental conditions, which culminated in the creation of the United Nations Conference on Trade and Development (UNCTAD), the introduction of the Generalized System of Preferences (GSP), and the acceptance of the differential treatment's principle during the General Agreement on Tariffs and Trade's (GATT) Tokyo Round (ALMEIDA, 2007; MAIOR, 2004).

Guimarães (2006: 259), who for seven years held the Foreign Ministry's General Secretariat position, establishes a clear relation between Brazil's sovereign international integration and Brazilian society's three main challenges: "... the decrease of extreme social disparities, the elimination of chronic social vulnerabilities, and the fast achievement of its potential."

We identify, therefore, that throughout President Luiz Inácio Lula da Silva's two mandates, there is a clear coherence between the pursuit of a greater sovereign insertion into globalization, the return of a national, developmental project's strategy, and the new State activism's agenda. It is still within this context that I will analyze in the following section Brazil's policy regarding the United States.

\section{Brazil- USA}

The central part of the search of a more active integration in the international arena is the renegotiation of the relationship with the great power, the United States. The new relationship with the U.S. was marked by the pursuit of a 
constructive level, but with clear recognition of the interests of each. Thus, one of the first acts of Lula's administration was to paralyze the procedure at the National Congress of the agreement to use the satellite launching base in Alcantara, which would give a near monopoly for the USA, while Brazil was seeking to establish a varied range of relations for the development of this technology.

Three months after the inauguration of President Lula, the Bush administration started the military invasion in Iraq. There was no hesitation from the Brazilian government in strongly condemning the U.S. and its allies for the war, which turned Brazil into a center of criticism of the conflict. But perhaps nothing better characterizes the spirit in which the Lula administration wanted to reestablish the basis of its relationship with the U.S. than one episode occurred during the first meeting of the G8 +5, in Evian, France, of which the President participated still in the first year of his mandate and which he insisted in recalling in details at several public events, including the Diplomat's Day in 2010:

I remember, in Evian, I had six months in office, with great pride, because I knew who I was representing there, and I knew where I had come from, and we arrived at a meeting, almost all presidents were there, except for the U.S. president. And we were sitting at some tables at the hotel where the meeting would take place, so, when Bush entered, everyone stood up. I told Celso: Celso, I'll remain on my chair, nobody stood up when I arrived. What is the subservience of people standing up because the U.S. president arrived? And it wasn't arrogance, it was just about respect ... And, humbly, Bush went at our table, greeted us and sat with us. There was nothing unusual. What would have been unusual was standing up as people usually did. This is one thing that really struck me.

It was this attitude of identifying an own agenda, in line with similar movements in other countries of South America, which led to the end of the proposed Free Trade Area of the Americas (FTAA).

And, as far back as the beginning of the first term, in 2003, Lula's administration led an articulation in the negotiations of the World Trade Organization (WTO) in Cancun, along with other developing countries, through 
the creation of the commercial G20. There was, at the same time, an articulated dialogue with great mobilization of civil society organizations from various countries to reduce the asymmetrical character of the negotiations, opposing a minimum agenda and its classic monopoly and the initiative of the central countries. Brazil also innovated by including, in the official negotiation, representatives of nonprofit civil society and the business sector.

It is important to consider that this did not mean the expression of an "anti-Americanism", as some analysts say (LAMPREIA, 2011), or a confrontation by the sake of it, but simply a re-articulation of the relation between both countries based on mutual respect. The other side of this policy was, for example, the insistence of Brazil in including the U.S. in the Group of Friends of Venezuela, which had the task of creating the conditions for a pacification of the political and social relations, after the failed coup attempt against President-elect Hugo Chavez. There was, at first, a resistance from Venezuela's president to include that who was considered an ally of the coup forces. But the whole logic of the Brazilian government was directed to changing the level of respect and attraction of U.S. to negotiations. Thus we can also analyze the firmness with which the government demanded respect of the WTO rules, which had condemned the U.S. as early as 2005, considering illegal the subsidies to local producers of cotton.

There was, however, at the same time, a heavy use of presidential diplomacy to seek convergence, which resulted, in fact, in a comprehensive bilateral policy dialogue. One example was the common agenda around the ethanol, formalized in 2007 through a Memorandum of Understanding, which provided for cooperation in research, product standardization and development of production in third parties, to expand production and markets ${ }^{5}$. More generally there was the formalization, in March 2010, of the Global Partnership Dialogue between the foreign ministries of both countries.

In his study of relations between Brazil and the U.S., Langevin (2010) concludes that:

${ }^{5}$ In mid-2011 this cooperation was incorporated into the Strategic Energy Dialogue, which, in addition to biofuels, comes from other renewable energy, oil, natural gas, energy efficiency and nuclear energy. 
These turbulent issues are representative of the increasing complexity of bilateral relations, largely driven by Brasilia's non-conformist but multilateral diplomacy aimed at changing the rules of global governance to lessen coercion and induce greater consent among "the rest." This global diplomacy necessarily challenges U.S. power and influence as currently exercised by the Obama administration. However, the dense bilateral fabric of social, organizational, and economic relations anchor both governments so that existing lines of communication and mechanisms for consultations can minimize political friction and maximize cooperation.

One of the author's arguments is the solid basis of economic relations between the two countries, evidenced by the evolution of the current trade and foreign direct investment from U.S. to Brazil. Both have grown consistently in absolute numbers from 2003 to the 2008 crisis (LANGEVIN, 2010: 7-8) ${ }^{6}$, despite the diversification strategy of Brazil, which resulted in a significant decrease of U.S. participation in the Brazilian trade current, as observed on Table 1.

Table 1: Brazil-US Exports/ Imports Trajectory

\begin{tabular}{|lllll|}
\hline & $\begin{array}{c}\text { Exports in US\$ } \\
\text { FOB }\end{array}$ & \% total exports & $\begin{array}{r}\text { Imports in US } \$ \\
\text { FOB }\end{array}$ & \multicolumn{1}{c|}{$\begin{array}{c}\text { \% total } \\
\text { imports }\end{array}$} \\
\hline \hline 2000 & 13,2 billion & $24 \%$ & 12,9 billion & $23,1 \%$ \\
2002 & 15,4 billion & $25,4 \%$ & 10,3 billion & $22 \%$ \\
2008 & 27,4 billion & $13,9 \%$ & 25,6 billion & $14,8 \%$ \\
2010 & 19,3 billion & $\mathbf{9 , 6 \%}$ & 27 billion & $\mathbf{1 4 , 9 \%}$ \\
\hline
\end{tabular}

Source: MDIC/Secex

Undoubtedly, in security issues, the U.S. still does not recognize Brazil as a partner to their standard, and a series of episodes had no constructive outcomes. We can cite as examples the case of U.S. ambiguous reaction to the coup in Honduras in June 2009; the unilateral U.S. action in Haiti shortly after the earthquake, without any coordination with the Brazilian-led United

6 The author used official U.S. government data available at <http://www.census.gov/foreigntrade/balance/c3510.html>. 
Nations (UN) troops; the military agreement signed with Colombia, with no dialogue in advance with Brazil; and, last but certainly the most contentious case, the articulation of Brazil with Turkey to unblock the impasse in the dialogue with Iran about the enrichment of uranium. The U.S. did not hesitate to isolate this initiative, mobilizing all its influence over allies and other permanent members of the UN Security Council. The fact that this is a regime marked by acts of gross violations of human rights weakened, both internationally and nationally, the legitimate and coherent position of Brazilian government in defense of the right to peaceful use of uranium, in accordance with the Treaty on Non-Proliferation of Nuclear Weapons (NPT).

\section{For a propositional multilateralism}

The repactuation of the relationship with the United States can be analyzed in the context of a policy in defense of a propositional multilateralism. This defense of multilateralism based on the legal equality of States is a historical milestone of Brazilian foreign policy and it was with this purpose that the country joined, over time, all relevant multilateral organizations. At various times, it obtained a clear connotation of opposition or neutralization of the logic of the management of the world order by the great powers (VIZENTINI, 2003). But, as stated by Almeida (2007: 79) “... Brazil made a defensive insertion in globalization ..."

The active insertion that Lula's administration sought implied, at the same time, claiming more space in the structures of international governance, a stance that had as its drive a reaffirmation of the old bid for a seat as permanent member of UN Security Council and a change of these same structures in defense of a less asymmetric and multipolar world. Some authors identify a classic dilemma between Brazil's claim for recognition equivalent to that of the great powers and, at the same time, the projection of the country as a mediator between great powers and the other members of the system in defense of the reform of international governance structures and less unequal international order (IPEA, 2010: 161). Other highlighted as one of the characteristics of Brazilian foreign policy its "double insertion", as the other Western country while part of the "Third World", which could be considered a 
reflection of Brazil as a nation of contrasts, but also its stage of development as middle power (LAFER, 2001).

The characteristic of an active policy of insertion, however, is to consider the relationship of international forces not as objective fact, but something subject to change. A potential for transformation that must be based on domestic economic, social and political constraints, but which, in turn, is sought to ensure the best conditions to sustain a neo-developmentalism policy. The difference is, therefore, guidelines and actions of foreign policy that guided the search of a series of alliances in the various fields in which one identified a potential to affirm the most active international insertion. Part of this guideline was clearly a renewed attention to the South-South relations, but in many other moments, it involved other actors, as was the case of the G4 (Brazil, India, Germany and Japan) to better articulate the bid to reform the UN Council Security.

Regarding the choice of South America, there was a gradual process of political integration among the countries of the two main existing blocs, the Southern Common Market (Mercosur) and the Andean Community of Nations (CAN). The member countries have become, symbolically, part of the other bloc as associate members. The next step was taken in 2004 with the formation of the South American Community of Nations (CASA), and later renamed and formalized as the Union of South American Nations (Unasur), as of the Establishing Treaty in Brasilia, in May 2008, which entered into force in February 2011.

Unasur can be understood as an attempt to create a political coordination that may represent a hub, in a world that, according to the vision of the Brazilian government and its partners, would be heading towards a multipolar structure. Unasur represents more than an innovative project of regional integration, a strategic vision which aims to consolidate its own identity. The priority areas of Unasur are the physical integration, and the integration in energy and in the field of defense. But there are also strong articulations in health and drug war. At the same time, the Unasur showed its prominence as a consultation way to contribute to overcoming the political crisis that occurred in Bolivia in 2008, and as of the debate about the installation of U.S. military bases in Colombia. In terms of Mercosur, it is worth emphasizing the broadening of the agenda, involving practically all spheres of 
public policy and focusing firmly on the construction of a Mercosur identity and citizenship, which should gain strength with the direct election to the Mercosur Parliament, starting in 2014. The recognition of asymmetries led the member countries of Mercosur to establish, in 2004, the Structural Convergence Fund of Mercosur (FOCEM), whose contributions have had an exponential increase in 2010 to meet, among others, the advance the electrification of Paraguay. The Brazilian private sector, the large contractors in particular, took advantage of new opportunities, starting to act more strongly in South America, gaining scale and competence, to move on to other markets after that. In this context, Brazil launched a mighty instrument for achieving integration policy and stimulating the performance of Brazilian companies in the subcontinent: the Brazilian Economic and Social Development Bank (BNDES). As far back as 2005, the president of BNDES, Guido Mantega, announced, during the first round of consultations for the construction of the South American Strategic Vision in Brazil, that BNDES "incorporated into its mission this strategic objective, acting as a funding body for the integration in South America". ${ }^{7}$ The BNDES is strategically positioned to finance exports of Brazilian goods and services and enterprises with the participation of Brazilian companies in South American countries. Thus, the BNDES arises and is seen as an instrument of Brazilian foreign policy to gain power and influence in the region. The direct operations of the Foreign Trade area are carried out especially through foreign funding to public entities, in order to facilitate the export of Brazilian goods and services. Between 2003 and 2009, the Brazilian government approved credit guarantees for about 100 BNDES financing projects already approved or pending approval in several countries of Latin America and the Caribbean, totaling about US\$ 15.6 billion ${ }^{8}$. In 2009 BNDES opened, as matter of fact, its first office outside Brazil - Montevideo, Uruguay.

This movement has the potential to establish a productive integration considered fundamental to the advancement of the integration process in

\footnotetext{
${ }^{7}<$ http://www.bndes.gov.br/SiteBNDES/export/sites/default/bndes_pt/Galerias/Arquivos/empresa/downl oad/apresentacoes/mantega_IIRSA.pdf>. Accessed on December 12, 2011.

${ }^{8}$ Interview with the president of BNDES, Luciano Coutinho, August 27, 2009, Valor Econômico. In the same interview, Coutinho claims that disbursements to the region doubled in 2007 and 2008, compared with the previous two years and should continue growing despite the crisis.
} 
Mercosur and the South America as a whole, as long as it is properly articulated with the regional public policies.

But this process is subject to several contradictions. On the one hand, the productive activities in neighboring countries can alleviate the fact that Brazil has a surplus with all countries of South America, except Bolivia, because in theory these investments generate jobs and income in recipient countries. It is noteworthy that Brazil's trade surplus with South America grew from US\$ 2.5 billion to US\$ 7.9 billion between 2003 and 2009 (MRE, 2011: 21 , which tends to aggravate the asymmetry between Brazil and its neighbors. At the same time, this active support to the actions of large Brazilian companies in South America can generate mistrust for representing powerful Brazilian interests that do not dialogue with national and local development strategies, resulting in social conflicts about enterprises, as it happened in Ecuador, Peru and Bolivia.

To ensure a permanent dialogue with the other Latin American countries, Brazil is actively engaged in the creation of the Community of Latin American and Caribbean States (CELAC). The first step was the meeting in December 2008 in Salvador, along with the Mercosur Summit, which ended up meeting, for the first time in the history of Latin America, heads of State and government of these countries without the patronage of the United States. At this time, the meeting was called Summit of Latin America and the Caribbean (CALC). It was in the second meeting of CALC in Cancun, Mexico, in February 2010, that it was decided by the creation of CELAC, which actually happened in Caracas, Venezuela, in December 2011. This process can somehow be characterized as the return of Mexico to the process of Latin American integration, which had turned away with the formation of the North American Free Trade Agreement (NAFTA) which entered into force in 1994 and led Brazil to rely more strongly on the integration restricted to South America. At the same time, CELAC can result in greater coordination with the sub-blocs existing in Central America (System of Central American Integration, SICA) and in the Caribbean (the Caribbean Community, CARICOM).

Another guideline, which took up some old abandoned experiments, was the opening for the African continent, with which Brazil has historical relations, being the country with the highest number of black people outside Africa, a number even greater than almost all the African countries themselves, 
except for Nigeria. The presidential diplomacy, through an intense schedule of visits $^{9}$, was essential to place the continent on a different level in the Brazilian external relations and public perception. This choice had as internal counterpart the decision to recognize the existence of profound inequalities of opportunity based on race and the need for a range of public policies coordinated by a new ministry called the Special Secretariat for Policies to Promote Racial Equality (SEPPIR). At the national level, emphasis was given to the educational policy which opened the doors of universities to a historically contingent that never had that opportunity. A detail of great symbolic significance that characterizes the new importance given to the historical relationship with Africa was the law 10.639, the first signed by President Lula in January 2003, which introduced the teaching of African-Brazilian History in compulsory curriculum in schools. In this context it is also worth remembering the affirmative action program of the Rio Branco Institute (Vocational Scholarship Award for Diplomacy) which granted between 2002, year of its creation, and 2010 nearly 400 scholarships ${ }^{10}$.

At the same time, the Ministry of External Relations (MRE ) started in 2010, through its Alexandre Gusmão Foundation (FUNAG), an annual effort to organize courses to African diplomats in Brazil sponsored by the Brazilian government. In the second course, held in 2011, diplomats from 12 countries participated: South Africa, Botswana, Ghana, Namibia, Nigeria, Kenya, Sudan, South Sudan, Tanzania, Zambia, Zimbabwe and Angola.

\footnotetext{
9 Between 2003 and 2010 the President Lula made 33 trips to Africa, visiting 23 countries in total. Source: Foreign Policy Balance 2003-2010, p. 35.

${ }_{10}$ Through the program, the government invests in the training of African descent to prepare candidates for the Entrance Examination for Diplomatic Career (CACD), conducted annually by the Rio Branco Institute. By 201117 alumni were able to integrate into the diplomatic corps.
} 
Table 2: Trajectory Export/Import Brazil - Africa

\begin{tabular}{|lllllll|}
\hline & $\begin{array}{l}\text { Exports in } \\
\text { FOB }\end{array}$ & $\begin{array}{l}\text { US } \$ \text { total } \\
\text { exports }\end{array}$ & Imports in US\$ FOB & $\begin{array}{l}\text { \% } \\
\text { imports }\end{array}$ \\
\hline \hline 1990 & 1 billion & $3,22 \%$ & 580.000 million & $2,8 \%$ \\
2000 & 1,35 billion & $2,44 \%$ & 2,9 billion & $5,21 \%$ \\
2003 & 2,9 billion & $3,91 \%$ & 3,3 billion & $6,81 \%$ \\
2008 & 10,2 billion & $5,14 \%$ & 15,8 billion & $9,11 \%$ \\
2010 & 9,3 billion & $4,59 \%$ & 11,3 billion & $6,22 \%$ \\
$\mathbf{2 0 1 1}$ & $\mathbf{1 1}$ billion & $\mathbf{4 , 7 2 \%}$ & $\mathbf{1 4 , 4}$ billion & $\mathbf{6 , 9 1 \%}$ \\
\hline
\end{tabular}

Source: MDIC/Secex

The relationship with Africa is, therefore, an example of a direct relationship between public policy and national strategy of international insertion and was expressed in a significant growth in trade (see table 2) and Brazilian investment, on the one hand, and on the other one, in numerous initiatives to contribute to develop cooperation; in fact, Brazil, who until recently saw itself as host country for international cooperation, understood that its new position would also demand taking responsibility in this field, although this change was not, necessarily, immediately understood by internal public opinion. Thus, the Brazilian Cooperation Agency (ABC), linked directly to the Ministry of External Relations, has moved, over the past year, from the agency organized to receive cooperation to an agency designed to contribute to the development in other Southern countries, particularly in Africa (IPEA, 2010). The emphasis is on cooperation, which expresses the know-how acquired by Brazil, such as support to combat AIDS, based on the success of its own policy of prevention and universal access to medicines for patients with HIV, partially made possible by the production of generic drugs. Thus, Brazil has been, via Oswaldo Cruz Foundation (Fiocruz) of the Ministry of Health, helping with the installation, in Mozambique, of a factory for the production of antiretroviral drugs.

At the multilateral level, Brazil actively participates with other countries of Unitaid, a purchasing hub of drugs against malaria, tuberculosis and HIV/AIDS, designed to meet the needs of the African continent. Other examples concern the mobilization of agricultural expertise by opening a regional office of the Brazilian Agricultural Research Enterprise (Embrapa), in Ghana, and the partnership to spread the technology of ethanol production. 


\section{Giorgio Romano Schutte}

This relationship with Africa was, as a matter of fact, shared with the South American partners by creating a forum for discussion of South America - Africa (ASA).

Similarly, there was a new reconciliation with the Arabic world. In the first year of administration, President Lula made a historic visit to Lebanon and Syria, which had only been visited before by a Head of State or Government of Brazil in the $19^{\text {th }}$ century, D. Pedro II. Brazil has the largest colony in the world of Lebanese origin, which justified prioritizing this visit. Also in the case of this relation with the Arab world, there was a South American articulation by organizing, in 2005 in Brasilia, the First Summit of South American - Arab Countries (ASPA), followed by a second summit in 2009 in Doha. The growth of the international profile of Brazil led the government to engage more actively in the peace process in the Middle East, firmly defending the option of two States. In the perception of the Brazilian government, there was room for the entrance of other speakers that could bring new perspectives to negotiation. In this context, besides the political support for direct negotiations between Israel and the Palestinian National Authority (PA), Brazil has provided technical and financial assistance for the reconstruction of Palestinian territories and the political and institutional strengthening of the $\mathrm{PA}$, considered fundamental to the construction of an independent Palestinian State.

Last but not least, there is the option of Brazil to politically organize with other middle and regional powers in defense of a change in global governance, for a less asymmetric world, with more opportunities for everyone. In this perspective, there was already in 2003, the mentioned articulation at the WTO and the called IBSA Forum (India, Brazil, South Africa), which provided a more permanent connection with democratic countries and middle powers with strong positions in their respective continents. The Forum has worked as political, sectoral (through working groups involving ministries) and development cooperation through the IBSA Fund. The political organization has highlighted Brazil and other members on the international scene regarding some issues on the global agenda. The latest example is the articulation to promote advances in environmental negotiations within the Conference of the Parties (COP) of the Framework Convention on Climate Change, the BASIC, 
created in early 2010 and that brings together Brazil, South Africa, India and China. With India, Germany and Japan, Brazil has articulated the G-4 for the reform of the Security Council of the United Nations (UNSC), defending the permanent seat for each of the four countries, in addition to an African country (South Africa or Nigeria) and an Arab country ${ }^{11}$.

The commitment to the UN gave a new quantitative and qualitative leap when Brazil took over, in 2004, the command of the troops of the UN Stabilization Mission in Haiti (MINUSTAH), in a clear perspective to Latin Americanize the peace process in Haiti, which had its counterpart by several other South American countries that sent troops, particularly Uruguay and Chile (HIRST, 2011). This responsibility assumed by Brazil provoked criticism at home that reflect in part the rapid change of its international operations, which requires broadening the debate and public participation and the organized sectors of civil society.

Contrary to the UN orientation, the Brazilian government has chosen not to create a specific quota dedicated to this operation, rather working with a rotation system that allowed thousands of troops to seize the opportunity to gain practical experience. In the case of operations in urban areas, a positive development action for the Brazilian society was the participation of military personnel, with special training and experience in Haiti, in the peacekeeping operations in favelas dominated by drug trafficking in Rio de Janeiro. At the same time the Brazilian government has mobilized several other ministries for cooperation with Haiti, working on food security, job training, health and infrastructure, to put into practice its conviction on the close link between conflict prevention and socioeconomic development, called by the Minister Celso Amorim as "Brazilian doctrine." 12

\section{The defense of a reform at the multilateral system}

The balance of foreign policy in the period of 2003 to 2010 begins with the statement that it was guided "by the idea that Brazil should take an increasing

\footnotetext{
${ }^{11}$ In this matter the resistance was very large and, after the departure of Chancellor Gerhard Schroeder, Germany reduced its interest. On the other hand, India has had, since the visit of President Barack Obama in late 2010, U.S. support, within the Sino-American political game.

${ }^{12}$ Interview published in the Journal of Development Challenges IPEA, Issue 61, May/June 2010.
} 
role on the international stage, projecting an image outside proud and sovereign", among others, contributing to "the design of a new framework of multilateral relations" (MRE, 2011). This vision marked in a systematic way the speech of President Luiz Inácio Lula da Silva, as can be seen on the table below, referring to excerpts of the speeches made in the traditional annual opening of the UN General Assembly.

\section{Table 1: Brazil's voice by the reform of the multilateral system}

\begin{tabular}{|c|c|}
\hline $\begin{array}{ll}\text { UN } & \text { General } \\
\text { Assembly } & \end{array}$ & $\begin{array}{l}\text { Excerpts from the speech of the President of Brazil in the } \\
\text { opening act }\end{array}$ \\
\hline September 23, 2003 & $\begin{array}{l}\text { "The improvement of the multilateral system is the necessary } \\
\text { counterpart on the democratic coexistence inside Nations." }\end{array}$ \\
\hline September 19, 2006 & $\begin{array}{l}\text { "The fight against hunger and poverty is also the establishment } \\
\text { of a world order that put the economic and social development in } \\
\text { the foreground. The subsidies in rich countries, particularly in } \\
\text { agriculture, are oppressive shackles that hold back progress and } \\
\text { doom poor countries to backwardness." }\end{array}$ \\
\hline September 25, 2007 & $\begin{array}{l}\text { "The construction of a new international order isn't a figure of } \\
\text { speech, but a requirement of reasonableness." }\end{array}$ \\
\hline September 23, 2008 & $\begin{array}{l}\text { "Given the global character of the crisis, solutions that may be } \\
\text { taken should also be global, decided in legitimate and trusted } \\
\text { multilateral fields, without impositions. From the United Nations } \\
\text { largest multilateral arena, must issue a call for a vigorous } \\
\text { response to the threats facing us. Simply by direct dialogue, } \\
\text { without the intermediation of the great powers, developing } \\
\text { countries have been accredited to perform a new role in the design } \\
\text { of a multipolar world." }\end{array}$ \\
\hline September 23, 2009 & $\begin{array}{l}\text { "It would be a huge mistake, an unforgivable historical omission, } \\
\text { to just take care of the consequences of the crisis without facing } \\
\text { their causes (...) More than the crisis of big banks, this is the crisis } \\
\text { of the great dogmas. What fell to the ground was all an } \\
\text { economical design, social policy and taken for granted. What } \\
\text { failed was an unreasonable model of thought and action that has } \\
\text { engulfed the world in recent decades. It was the absurd doctrine } \\
\text { that markets could self-regulate themselves, dispensing with any } \\
\text { State intervention, considered by many a mere nuisance. It was } \\
\text { the thesis of absolute freedom for financial capital, without rules } \\
\text { or transparency, above the people and institutions (..) The poor } \\
\text { and developing countries must increase their participation in the } \\
\text { IMF and the Bank. Multilateral world. It may be a factor in the } \\
\text { revitalization of the UN." }\end{array}$ \\
\hline
\end{tabular}


As discussed, the common denominator to the various joint efforts with other countries, both within the formal structures and the creation of new informal groupings, the strategy was to project the interests linked to the internal neo-developmentalism efforts with proposals for changes in global governance. There is a tendency to confuse the emphasis on South-South articulation with an out-of-time Third Worldism, usually associated with a critical view of this policy. No doubt there are elements that refer to the spirit of Bandung, but the theme of non-alignment is no longer on the agenda. There remains the challenge of asymmetry which increases the concentration of wealth and political power. The 1955 Bandung Conference, in Indonesia, guided the recognition of the right to development by countries that have recently gotten rid of colonization of Latin Americans who sought their own nationaldevelopmentalism project. Now the staff is in recognition of increasing interdependence and real changes in growth prospects, especially by the socalled emerging economies, whose weight is not reflected in the growing international governance structures. That is, there was no longer only guided the problem, but to show that countries until recently considered peripheral are also part of the solution.

\subsection{The fight against hunger and extreme poverty}

In the first year of his first term, in January 2003, President Luiz Inácio Lula da Silva was projected as a new global leadership by being the only head of government or state to attend the World Social Forum in Porto Alegre and the World Economic Forum in Davos, with a single speech, focused on fighting hunger and extreme poverty; a new version of the capacity, as mentioned above, of Brazil to dialogue with the various audiences and interests. This flag was also chosen to highlight the need to rethink the logic of the global economic order. Given the U.S. war in Iraq, Brazil was articulated, in 2004, with the governments of France and Chile around what was called the Global Action Against Hunger and Poverty. In the initiative has joined Spain, just after the election victory of Jose Luis Zapatero, who had among his flags, the immediate withdrawal of Spanish troops from Iraq. There was also support from the General Secretariat of the UN, since Kofi Annan identified the possibility of a mobilization around a positive agenda in opposition to the agenda of the war, which had started even in defiance of the UN. The result of this joint was 
presented on the eve of the opening of the General Assembly in New York in September 2004, focusing on innovative financial mechanisms. The Foreign Ministry's note about this event states: "We share the view that tackling poverty and social injustice in the world is vital to the security and stability of all countries, both developed and developing." 13 The event was attended by 55 heads of State and government, and the resolution of the General Assembly to continue the efforts at the multilateral level was approved by 115 countries. This demonstration of the ability to mobilize apparently emptied due to the difficulty of Brazil to give substance to the appeal and make the proposals forward ${ }^{14}$. The initiative has become the Leading Group on Innovative Financing for Development, which teamed up, in July 2011, 63 countries and dozens of international and nongovernmental organizations. Apparently there was an excess of voluntarism and projection and the reference to the campaign gradually lost space. But on the other hand, it was used to mark the position and guided around a subject to which Brazil would protrude in other ways. One can identify, among others, the internationalization of Embrapa by opening a regional office in Ghana, the cooperation programs for ethanol production in Central American countries and African countries with the joint African cotton producers - Benin, Burkina Faso, Chad and Mali - the Cotton-4 and the very inclusion of the issue of food safety in cooperation with Haiti. It is no accident that, after several failed attempts to transform the international projection of Brazil in actual occupation of positions of leadership, success occurred precisely at the United Nations Food and Agriculture (Food and Agricultural Organization, FAO), with the election in 2011, José Graziano da Silvapara the post of secretary-general.

It is possible to make a clear parallel with the internal government action that justified the international projection, the Zero Hunger campaign. Also in this case, it was released with much political projection, but without a

\footnotetext{
$13<$ http://www.itamaraty.gov.br/sala-de-imprensa/notas-a-imprensa/2004/09/21/declaracao-de-novayork-sobre-a-acao-contra-a-fome $>$.

14 A Technical Group on Innovative Financing Mechanisms comprises officials from the four governments and consultants related to the UN Secretary-General prepared a document with eight proposals, including tax on foreign exchange flows, new issue of Special Drawing Rights, fighting tax havens, among other.
} 
clear organization and structure. And it also vanished somewhere on the agenda but the agenda was and resulted in a series of actions and measures, the Family Grant Program funding for the expansion of family farming and school feeding programs, among others. The mandate of combating hunger and poverty that marked the national priority represented at the international level, however, a central element to point to the need to rethink the international order. Appeared, including the question of subsidies by the EU and U.S. to their farmers, the main obstacle to the Doha Round.

The question that arises is whether Brazil could actually be seen by the international community as one of the leaders, and South America as one of the poles, of the multipolar world under construction. That is, to what extent the new emphases and new assertiveness of Brazilian foreign policy were based on advances and consolidated internally and in a real evaluation of the potential for a larger space for Brazil in the changing world? The next two sections discuss this issue, respectively, from the 2008 crisis, and the real resources available to look scenarios and future strategies.

\section{The 2008 crisis: the virtú finds l'occasione}

In June 2011, the foreign correspondent Assis Moreira commented on their practice: "A lot has changed. Before, it was complicated even to get credentials to cover major international events. Today, with the country in the G20, access is facilitated." 15 This is a small illustration of how the constitution of the G20 not only consolidated the new role of Brazil, but has also expanded its horizon. It is true that the group has lost the charm with which it was received at birth in November 2008. Nevertheless, it remains the principal forum for intergovernmental debate on economic and financial issues.

For Brazil, the 2008 crisis, which led to the G20, arrived at a time allowed to combine virtú with fortune. The government had found a path of sustained growth with popular support and accumulated reserves. And the president had already gained experience and recognition after nearly six years of projection as a charismatic leader and head of an emerging country. In fact, when the crisis exploded in September 2008 with the collapse of Lehman

15 Valor Econômico, EU \& Fim de semana, June 10, 2011. 
Brothers, Brazil was growing at a rate exceeding $7 \%$ and had just won investment $\operatorname{grade}^{16}$. Not only the population but also the world came to recognize that Brazil had taken a leap forward in both the strategy development, generating millions of formal jobs and consolidating a trend of decreasing socioeconomic inequalities, and in respect of the its insertion in the international arena. As an exercise, one can imagine what would have been the fate of Brazil and the government had the financial crisis exploded in mid-2005 when the president's popularity was slightly above $30 \%$, the country plunged into political crisis, no defined development strategy and without international reserves, growing at a rate slightly above $2 \%$. That is, when the crisis erupted, Brazil was more than prepared to defend itself, daring to take countercyclical measures and to occupy a prominent international coordination in order to avoid aggravation of the crisis itself and also to increase the country's presence in international forums permanently. If nothing else, chance had placed the country, precisely in 2008, the presidency of the G20 finance ministers.

Brazil is presented and it was now seen as part of the solution. The developmental orientation of economic policy implemented since 2005 had borne fruit, and muscle to defend the country, with an internal market, social policy and income redistribution strongly countercyclical and international reserves (BARBOSA, 2010). Brazil reacted to the crisis so purposeful, even financially, generating in 2009 about one million jobs. The very success of the reaction to external threat, avoiding the traditional currency collapse and its devastating effects on the real economy, served to legitimize such policies, such as the renewed importance given to public sector banks (JAYME; CROCCO, $2010)$.

Externally the Brazilian government knew articulate immediately with new partners to bring about an expansion of the forum for coordination with the intention to give a response to the crisis. In the rotating presidency of the G20 Ministerial in 2008, Brazil had since the beginning of management, based the need to transform the G20 into a forum for leaders and increased frequency

\footnotetext{
${ }_{16}$ We disagree on, however, the assessment made by Alston and Mueller (2011) that the investment grade rating by the rating agencies themselves have been central to Brazil began to attract a significant volume of foreign capital and consistent. Much more than cause, the investment grade reflects a real change and perception of international investors about the prospects of the Brazilian economy.
} 
of technical meetings to expand their operations. When the globalized crisis became global, after the bankruptcy of investment bank Lehman Brothers, the G20 organized an extraordinary meeting on October 8, 2008. At the last minute there was a surprise participation of President George W. Bush, less than one month of the presidential election in November 4. With the French presidency of the European Union there was a heightened pressure to conduct a meeting of leaders and President George W. Bush agreed to host the first meeting in Washington. There was still no clarity on the scale of the crisis and its possible systemic character. But there was a clear reminder of mistakes made before the 1929 crash, when the lack of international coordination was one of the determining factors for the worsening of the crisis and its dramatic consequences. To facilitate the choice, we opted to use the format of the G20 ministerial, thus avoiding a debate about its membership, despite the clear over-representation of under-representation of Europe and Africa (South Africa only).

In less than a year were made three meetings of the G20 Leaders (Washington on November 2008, London on April 2009, Pittsburgh on September 2009), an intensive consultation of high-level unprecedented since the end of World War II. With the Pittsburgh Summit, concluded the first phase, in which the leaders had issued a firm signal to economic agents and guaranteed liquidity to avert the nightmare of a total collapse of the international financial system, although we haven't managed to avoid contamination of the real sector of the economy, with serious consequences for employment, particularly in the U.S. and some European countries (Ireland, Spain).

The dual transformation of the G-7 and G20 Ministerial Summit of the G-20 allowed Brazil, alongside Argentina, South Africa and other BRIC countries (Brazil, Russia, India and China), defend their positions, for example, in relation to governance reform of the International Monetary Fund (IMF), which resulted in increasing its voting power, which jumped from $18^{\text {th }}$ to $10^{\text {th }}$ position. Or, in general, include in the agenda of the G-20 issues related to the challenges to sustainable development, besides the financial crisis, such as decent work, involving the International Labour Organization (ILO).

Although, the expectations of a possible Bretton Woods II haven't been realized, it can be argued that the G20 represented a new milestone in 
multilateralism. It created a platform on which the powers of the situation defend the maintenance of their privileges on the side of countries that claim to enlarge your space in support of national development strategies. It is not just a cyclical response to the crisis, but a necessary adaptation of the institutional superstructure to the new reality of international economic relations. By the same token, countries with emerging economies, including Brazil, formally became part of the Basel Committee with voice and vote in both the Committee on the Global Financial System (responsible for monitoring financial markets in order to identify and assess potential sources of instability), and the Committee on Capital Markets (responsible for keeping abreast of trends in the financial market). Besides Brazil, entered on the Basel Committee, Australia, China, South Korea, India, Mexico and Russia.

In this sense, the G20 was a consistent commitment with the thrust of Lula's foreign policy, but also articulation with the other BRIC countries, to get more bargaining power, which actually worked, as suggested, in particular respect to changes in power structures of the International Financial Institutions (IFI's) and their own replacement of G8 by the G20 as the main forum for coordinating economic and financial crisis. No doubt the G20 stimulated the consolidation of the BRIC (and then BRICS) as a consultation group, balancing the continuity of the G7.

It's worth emphasizing the active role of the Brazilian government to articulate the emergence of BRIC and include South Africa. It was Russia, consistent with its vision of a multipolar world, who assumed the responsibility to convene the first meeting of heads of state and government. The vision of President Vladimir Putin was clearly expressed in his speech at the Conference of the Organization for Security and Cooperation in Europe (OSCE) in 2007 in Munich, when he said:

I consider that the unipolar model is not only unacceptable but also impossible in today's world. And this is not only because if there was individual leadership in today's - and precisely in today's - world, then the military, political and economic resources would not suffice. What is even more important is that the model itself is flawed because at its basis there is and can be no moral foundations for modern civilisation. 
In that spirit, Russia organized in June 2009 - between the $2^{\text {nd }}$ (London, April 2009) and the $3^{\text {rd }}$ Summit (Pittsburg, September 2009) G20 - in the city of Yekaterinburg, the first BRIC Summit.

Brazil was still somewhat of an outsider on the other three giants that share borders and centuries of coexistence, war and peace. But since the countries were considered key parts to overcoming the global crisis. It was the $2^{\text {nd }}$ meeting in Brasilia in April 2010, that Brazil also invited South Africa to make the event coincide with the Summit of the IBSA (India, Brazil, South Africa). The extension of this joint was of interest to Brazil. On the eve of the third Summit in China, the government of South Africa published in major newspapers and parcel of the economic grouping of countries, a statement under the heading "Accessing Africa with BRICS" stating:

December 23, 2010 was an auspicious day, marking the date on which South Africa was formally invited into the economic coalition between Brazil, Russia, India and China (BRIC) to expand the acronym to BRICS(...)IBSA would be strengthened and more balanced with South Africa as a BRICS member, particularly as the mandates of both organisations were highly complementary.

The statement identifies the BRICS as "the widely-accepted symbol for global economic power shifting from the developed to the developing nations ${ }^{17}$."

\section{A new reality}

This transformation of the BRIC from a category of analysis in a group involving Brazil, Russia, India, China and South Africa, reflects the desire to seek changes in the structures of international governance that reflect the gradual changes in the relations of economic power, a process that was evident and accelerated with the 2008 crisis.

It's observed that particularly in relation to Brazil there was a shift in perception. By 2008 there were doubts whether if the B from the BRIC really would fit this category of analysis, since the country didn't have high rates of

\footnotetext{
${ }^{17}$ In Brazil, the statement was published by the newspaper Economic Value on 13 April 2011. See also $<$ http://www.southafrica.info/global/brics/brics-080411.htm>.
} 
economic growth and the other didn't share with them the military, particularly the possession of nuclear weapons. But with the emergence of the BRIC group, this question has been overcome.

What interests us here is to present an assessment of the prospects, apart from possible points above the curve due to cyclical issues or the fact that it was able to take a ride on the need for part of the G7 agreeing a new relationship with China. Even considering that the Brazilian active inclusion strategy now lacks one who had become a powerful resource, the very figure of the leader, President Luiz Inácio Lula da Silva, ahead of presidential diplomacy ${ }^{18}$.

In this aspect, we highlight five points that seem relevant to the projection continuity scenarios discussed of new insertion of Brazil: their growing economic weight, the pre-salt, the environmental issue, the issue of food production and single exposure of the country before the world public opinion with the realization, in a very short time, the two major televised events in the world.

\subsection{The participation of Brazil in world economy}

The advances made in developmentalism economic policy through the stake in the domestic market and decreased slow, gradual, but constant inequality, considered a historic setback for the modernization of the country, created an opportunity that drew the attention of international capital. At the same time, Brazil has significantly expanded its export base, but increasingly specialized in commodities. On the other hand, there has been a coveted market, mostly referring to manufactured goods. The result is a constant and significant increase of bilateral trade, interrupted by the impact of global crisis, but quickly resumed, as shown in Chart 1. Data on flows of foreign direct investment (IED) targeted to Brazil go in the same direction. The World Investment Report 2011, (UNCTAD) shows that the country reached the $5^{\text {th }}$ place in terms of attraction of these flows, despite all the supposed difficulties of doing business in Brazil, appointed annually by the Doing Business Report of

18 We agree with the observation Hirst, Lima and Pinheiro that presidential diplomacy of Lula's government is not sufficiently evaluated as substantive promoter of Brazilian foreign policy (2010, p.28). 
the World Bank ${ }^{19}$. Chart 2 shows the recent trajectory and market expectations concerning IED in billions of US\$. With this, the country's participation in global IED flows jumped from $1.3 \%$ in 2006 and $2.2 \%$ in 2009 to $3.9 \%$ in 2010 . The forecast of the Central Bank of Brazil for 2011, US\$ 55 billion, is even bigger than market expectations and points to $4.3 \%$ of the overall flow. This reality must allow the Brazilian government to recognize their bargaining power to agree with multinational companies a greater effort to attract innovation and research and development centers.

\section{Chart 1: Current Brazil-U.S. trade $\$$ billion}

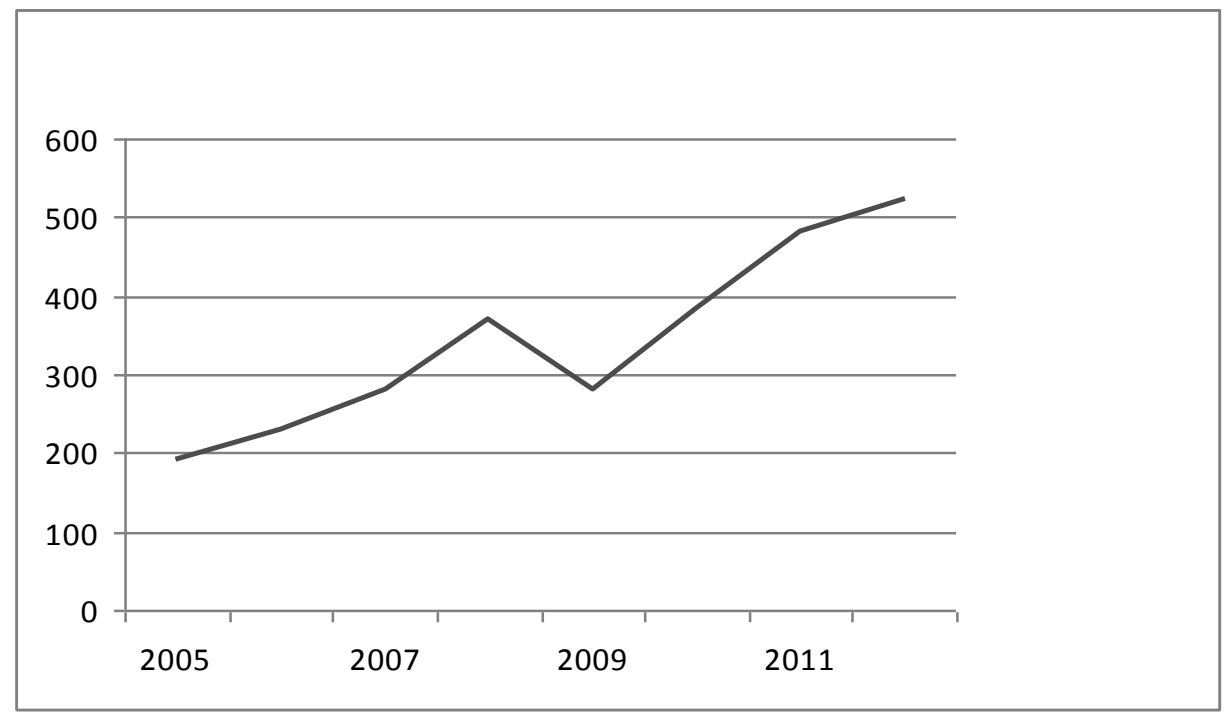

Source: Central Bank for the years 2005-2010, Focus / Bradesco-Depec "Expectations of the market in August 2011" for the years 2011 and 2012.

\footnotetext{
$19<$ http://portugues.doingbusiness.org/data/exploreeconomies/brazil/>.
} 
Chart 2: Flow of Brazil-U.S. Foreign Direct Investment $\$$ billion

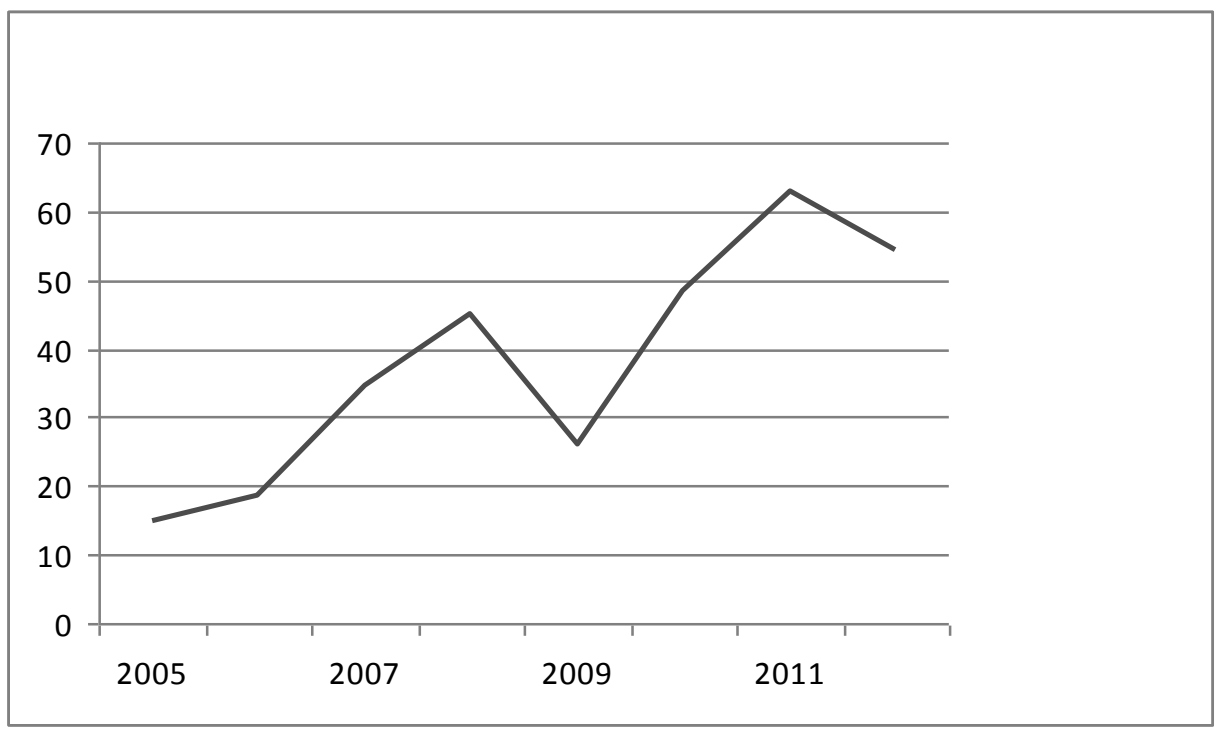

Source: Central Bank for the years 2005-2010, Focus/Bradesco-Depec "Expectations of the market, December 2011" for the years 2011 and 2012

It won't be, in this work, discussed the new challenges that this situation poses for Brazil, for example, to manage the capital account, dealing with the trend of appreciation of the real or the need to move quickly on the qualification of local workforce to seize the opportunities created.

\subsection{The Pre-Salt}

It is difficult to say how much the new attraction of Brazil already is due to the pre-salt, but there is no doubt that this mega-discovery, by itself, projecting the country in a different way in the coming decades. There is also a survey about the amount of oil and gas that pre-salt really represents, but estimates range between 50 billion to 100 billion barrels ${ }^{20}$. The Ten Year Plan for Expansion of Energy 2020 (PDE) from mid-2011 prepared by the Energy Research Company (EPE), projected an increase in oil production, including gas and international

\footnotetext{
${ }^{20}$ A barrel equivalent to 159 liters of oil.
} 
production, the current 2 million barrels per day for 6,1 million barrels per day, which would give a capacity to export 3,2 million barrels per day in $2020^{21}$.

Table 3 considers only the production of oil in Brazil, without regard to the production of gas equivalent and production abroad by Brazilian companies, but estimated in addition to production in fields in operation and that of the contingent resources (discovered, already granted and in evaluation), the undiscovered resources in exploration blocks under concession and also the start of production in the Union area hasn't granted.

Table 3 - Production of oil in barrels per day and future forecast 2017-2020

\begin{tabular}{l|l|l|l|l|l}
\hline \multicolumn{1}{c|}{ Country } & $\mathbf{1 9 9 9}$ & $\mathbf{2 0 0 9}$ & $\mathbf{2 0 1 0}$ & $\mathbf{2 0 1 7}$ & $\mathbf{2 0 2 0}$ \\
\hline Rusia & 6,2 & 10,0 & 10,27 & & \\
\hline South Arabia & 8,9 & 9,7 & 10 & & \\
\hline United States & 7,7 & 7,2 & 7,5 & & \\
\hline Iran & 3,6 & 4,2 & 4,25 & & \\
\hline China & 3,2 & 3,8 & 4 & & \\
\hline Brazil & 1,1 & 2,0 & 2,14 & 3,824 & 6,09 \\
\hline
\end{tabular}

Source: BP Statistics for numbers of other countries; EPE / Ministry of Mining and Energy (MME) for figures and forecasts in Brazil.

Table 3 illustrates that Brazil was a small player in 2009 and returned to the small domestic market, which occupy fourth place in 2020 , in the event none of the producing countries to increase their production there.

Also with regard to reserves, depending on the size of the pre-salt, Brazil occupy between the $5^{\text {th }}$ and $8^{\text {th }}$ place, behind only the great and historical players in the Middle East, Russia and Venezuela, and the reserves of the latter country are composed the so-called large-scale non-conventional oil (ultraheavy oil).

The estimate of Petrobras is that the break-even point of the pre-salt is around US\$ 35 per barrel. There are strong arguments to suggest that its feasibility is guaranteed for two reasons. First, although we are entering the phase transition towards a low carbon energy sources, this process should take

$21<$ http://www.epe.gov.br/PDEE/Forms/EPEEstudo.aspx>. 
even a few decades and during this period, the need for emerging economies, particularly China, India and Brazil, will pull the up demand. Only the Chinese demand for oil has increased from 4.48 million b/d in 1999 to 7.7 million b/d in 2007 and 8.6 million in 2009, much higher than the expansion of its domestic production $^{22}$. At the same time there is a breakdown of production in various regions of the world, as is the case of Mexico, the North Sea and the U.S. itself, which still holds in 2010, a production of around 7 million b/d, but presents a demand that exceeds 20 million b/d. The pre-salt, as the main area of frontier expansion of oil production in the world, is therefore in the crosshairs of the U.S. and China.

A sovereign insertion strategy involves establishing a national control over strategic decisions and ensure that this discovery will become a major lever for national development and, therefore, the country's geopolitical projection. The changes in the regulatory framework adopted into law in 2010 had this goal, but they represent only the beginning and still require a broad debate to the detailing and consolidation. One of the key points is to ensure that the rate of exploitation is compatible with the absorption capacity of the country with regard to managing the inflow of foreign currency on the foreign accounts, in particular the exchange rate, and management of resources such as extrabudget, not so much because it's a finite resource, but mainly because they are highly volatile revenues. To meet these two challenges, it were approved the creation of bases for, respectively, a Sovereign Wealth Fund and Social Fund. Through the Sovereign Fund, funds in U.S. dollars may be used for international operations without going through the internalization in the country, for example, to finance Brazilian foreign direct investment, credit for export or investment credit, returning to the domestic economy in particularly in the area of infrastructural projects in South America. The Social Fund should ensure the channeling of funds obtained through uptake of oil revenues by the State for high priority areas for development in medium and long term ${ }^{23}$.

\footnotetext{
${ }^{22}$ British Petroleum (BP) statistical <www.bp.com>.

23 Law 12351 enacted on December 22, 2010, specifically mentions as allocation of resources on education, culture, sports, public health, science and technology, environment and mitigation and adaptation to climate change.
} 
At the same time, the criterion of absorption also refers to the ability to extend and enhance the industrial park to ensure that the growth in upstream chain demand (on exploration and, especially in production) and downstream opportunities (in productive activities that use oil and gas as inputs, such as petrochemical-plastic chain) can be met by domestic production, generating employment and income in the country and the region. It's observed that the size of demand and its consistency over time allows you to plan investments in medium-long term, creating critical mass to meet, then external demands. Remember that offshore production is the most technologically advanced oil production, and pre-salt, in particular, requires the development of high technology in the areas of nanotechnology and new materials. Not surprisingly, there has been a rapid movement on the part of global business leaders in high technology services to the oil industry to install capacity of Research and Development in Rio de Janeiro, as is the case of General Electrics (GE), Schlumberger, IBM, FMC Technologies, Baker Hughes, Halliburton, Tenaris Confab and others. The pre-salt put Brazil among the priorities of these companies. Certainly the actions of Petrobras Research Center (Cenpes), on the Fundão Island, and the expansion of its facilities, completed in 2010, is a crucial factor of attraction. With the expansion, Cenpes occupy over 300 square meters, making it one of the largest applied research centers in the world.

Last but not the point of little relevance, the pre-salt feeds also the discussion on the defense strategy and, in particular the modernization of the Navy and Air Force. The Treaty of Montego Bay, 1982, which stipulates the exclusive right to operate up to 200 nautical miles from shore (the Exclusive Economic Zone, ZEE) and the recognition of Brazilian claim in respect of an additional 150 nautical miles for the design of the Brazilian Platform Continental (Blue Amazonia) was, until mid-2011, ratified by 161 countries except the U.S. From the formal point of view of public international law, this implies that, for now, the U.S. doesn't recognize Brazil's sovereignty over the area of pre-salt. In this context, should be considered strategic partnership with France to buy Scorpène submarines and cooperation to build the first nuclear submarine. The same goes for the air force modernization, particularly the procurement of fighter aircraft. It's important to recognize that the pre-salt changes any future scenario on the insertion of Brazil, putting the country on 


\section{Giorgio Romano Schutte}

another level in world geopolitics, which involves, as noted, challenges, and great opportunities.

\subsection{The Brazil as environmental power}

In the five areas that we can identify when discussing environmental governance, climate change, biodiversity, genetic resources, biosafety and forests, Brazil, by its natural resources, it would be already a relevant player. But the result of strategies adopted in the pursuit of self-sufficiency energy gave the country a comparative advantage and an authority and influence in the debate that tends to occupy an increasing space on the international agenda (IPEA, 2010b).

The first point to be emphasized is the cleanest energy matrix. Data Research Company (EPE) shows that the use of renewable sources in Brazil is close to $45 \%$, against a world average of around 14\% (TOLMASQUIM, 2007). This is explained by the use of hydroelectric power (energy) and ethanol (fuel and energy co-generation), most recently adding a significant increase in wind power, although as an additional source.

Brazil began to take its place in 1992, hosting the United Nations Conference on Environment and Development in Rio de Janeiro, at which time the Convention was signed United Nations Framework Convention on Climate Change. Since the beginning, consistent with its traditional positions and interests as a developing country, defended the principle of "common responsibilities, but differentiated", based on historical of developed countries on the one hand, and the right to development, other. At the same time, there was a defense mechanism for transferring resources to enable developing countries to contribute to mitigation efforts and adaptation. Last but not least, a very great care in defense of sovereignty, particularly in the debate that surrounds the Amazon rainforest. What was an innovative approach, a reflection of active participation in building the climate change regime, has now become an obstacle to Brazil assume more leadership. Considering the peculiarities mentioned, the country can contribute more to the provision of global public good (climate stability) without sacrificing their national interests. The reference to the historical responsibility remains valid, but more interesting is the fact that Brazil can point the structure of supply of clean energy. It was 
precisely this debate that marked the position of Brazil on the eve of the COP 15 in Copenhagen in December 2009. The country had provided voluntarily adopt reduction targets bold, because they would be focused primarily on reducing deforestation, which has a low cost. Here we must emphasize one fact relatively little assimilated by opinion makers, and consequently, the Brazilian public opinion: the extraordinary success of Brazil in significant reductions in Amazon deforestation during the period 2005-2008 compared with 2001-2004, which kept the high pace of the previous decade. It took an average annual deforestation of $20 \mathrm{mil} \mathrm{km} \mathrm{km}^{2}$ for an annual average of $13 \mathrm{mil} \mathrm{km}^{2}$ (VIOLA, 2010). This enabled a reduction in emissions of greenhouse gases (GEE) of Brazil in this period of about $20 \%$, which was unprecedented in the world. Brazil had therefore everything to project itself as a global actor, and actively contribute to the advancement of the negotiations, leaving behind a defensive posture, attached to the supposedly sovereign interests that wouldn't succumb to outside interests. There was a surprising change. On the eve of the COP 15 in Copenhagen, was announced the new government's position by the Minister of Environment, Carlos Minc, and the Minister of Staff, Dilma Rousseff. For Viola (2010: 107), the new positioning of the Brazilian government:

...implies a change in the history of foreign climate policy in Brazil and a strategic defeat of the two ministries that defined the position of the country between 1996 and 2009 (the MRE and MCT). It's, however, a victory for the Environment Ministry, which is challenging the traditional position since 2006 and has assumed a very incisive questioning position since 2008 .

The new positioning, assuming concrete targets for reducing greenhouse gas emissions, was codified in Law $\mathrm{N}^{\circ} 12.187$ of December 29, 2009, and meant, in view of the government, a reduction of $36.1 \%$ to $38.9 \%$ in relative to its projection for 2020. This position should encourage other developing countries to announce similar goals. The challenge posed is to prevent the pre-salt interrupt this Brazilian trajectory and, instead, the revenue generated by oil production are in fact channeled to the country with advanced technologies is leading the transition to a low carbon. 
In December 2011, the Ministry of the Environment released the figures of Prodes, system of the National Institute for Space Research (INPE), which monitors deforestation annually, showing that deforestation in the Amazon reached the lowest levels since 1988. The deforested area from August 2010 to July 2011 was 6.2 thousand square kilometers. If these figures are consolidated, Brazil will have fulfilled the goals of reducing deforestation assumed at the Climate Conference in Copenhagen in $2009^{24}$.

The realization of the UN Conference on Sustainable Development Rio+20, in June 2012, should increase the internal debate on the consolidation and continuity of policies to combat deforestation. The conference will also be the time to reaffirm the important role of Brazil on this issue.

\subsection{Brazil and food production}

The country has significant growth in international trade of agribusiness, consolidating its position as one of the largest producers and exporters of food to over 200 countries. Population growth and urbanization processes in Africa and Asia, should press the demand for food in the coming decades. Data from the United Nations Population Fund (UNFPA, 2011) indicate an increasing world population of 6.9 billion in 2010 to 9.15 billion in 2050. This growth, almost entirely concentrated in developing countries. The FAO estimates the need to double food production between 2010 and 2050. Food production will remain so in the coming decades, one of the most important challenges facing humanity.

In 2010, Brazil was the second largest supplier in the international food market, behind only of the U.S., but growth projections indicate a potential for the country to become the largest supplier of animal protein and vegetable world. A study from OCDE together with the FAO (2010: 20) points Brazil as the country with higher growth potential of production, estimated at $40 \%$ by 2019, using as basis the average annual production in the period 2007 to 2009. In the U.S. case, the estimate is an increase of $10 \%$ over the same period.

The combination of sustainable growth potential, with the prospect to take the place of the largest producer and exporter in the world puts Brazil in a

${ }^{24}$ Source: Bulletin In Question, number 1425, 7 December 2011. 
leadership position around one of the key issues for human survival. The concentration of joint efforts to ensure the aforementioned election of José Graziano da Silva, in June 2011, for the post of Director-General of FAO, was right, and his victory express recognition of the country's strength in agriculture and food.

\section{Final considerations}

In this work we have tried to analyze the consistency of activism in the field of international relations, with the search of a new national developmental project. What determines the inclusion of a country, however, is not only determined by the guidelines of foreign policy, but also depends on internal economic, social and political conditions, and, above all, the actual correlation of international forces. The financial crisis of 2008 showed clearly the progress made by Brazil that allowed it to react, continuing the government's priority in the area of job creation and income distribution.

At the same time, the crisis showed a gradual change in the international power in economic structures, opening thereby a real possibility of seeking more space for Brazil, along with other middle income countries, in the structures of international governance. This has created a series of new challenges for Brazil with regard to the need to adapting the institutional framework and the necessary qualifications to seize new opportunities and occupy, with the priority, the newly conquered areas.

Finally, as argued, there was a significant change in the perception of Brazil in the world, far beyond the aforementioned investment grade rating obtained in 2008. There is now a unique opportunity for Brazil to dialogue with the world public opinion to make, in short time, the Soccer World Cup (2014) and the Olympic Games (2016), the two events with greater global audience via television and internet.

Any assessment of the medium-long term scenarios and possible strategies for international insertion should, however, take into account a range of strategic resources which the country began to have, the pre-salt, food production capacity and environment al assets. These features might not be recognized as hard power, but surely, considering its relevance to the world economy, it is not simply soft power, moving away from the classification of Nye (2004). 
The geopolitical implications of using these resources will depend again on external conditions, but also the guidelines for its management and, in particular, the way that they will be subject or not to a development strategy discussed and shared by several sectors of society. The several options and their geopolitical implications should be the subject of future research.

\section{REFERENCES}

ALMEIDA, Paulo Roberto. As relações econômicas internacionais do Brasil dos anos 1950 aos 80. Revista Brasileira de Política Internacional, no 50 (2), 2007.

ALSTON, Lee; Mueller, Bernardo. Brazilian Development: This Time for Real? CESifo Forum, 01/2011.

BARboSA, Nelson; Souza, José Antônio Pereira. A inflexão do Governo Lula: Política Econômica, Crescimento e Distribuição de Renda. In: Garcia, Marco Aurélio e Sader, Emir (Org) Brasil entre o Passado e o Futuro. São Paulo: Editora Fundação Perseu Abramo/Boitempo, 2010.

CARDoso, Fernando Henrique; Faletto, Enzo. Dependência e Desenvolvimento na América Latina. Rio de Janeiro: Civilização Brasileira, 2004.

ERBER, Fabio S. Convenções de desenvolvimento no Brasil contemporâneo: um ensaio de economia política. Textos para discussão Cepal/IPEA. Brasília, 2010.

GARCIA, Marco Aurélio. Respostas da Política Externa Brasileira às Incertezas do Mundo Atual. Interesse Nacional, Ano 4, Edição 13, Abril a Junho de 2011.

GUIMARÃES, Samuel Pinheiros. Desafios brasileiros na era dos gigantes. Rio de Janeiro: Contraponto, 2006.

HIRST, Mônica. Las relaciones triangulares Estados Unidos, Unión Europea y América Latina. Pensamiento Iberoamericano, número 8, 2011.

HIRST, Mônica; Lima, Regina Soares; Pinheiro, Leticia. A Política Externa brasileira em tempos de novos horizontes e desafios. Nueva Sociedad, Especial 2010.

IPEA. Cooperação Brasileiro para o Desenvolvimento Internacional. Brasília: IPEA, 2010.

IPEA. Inserção Internacional Brasileira: temas de política externa. Livro 3, Volume 1. Brasília: IPEA, 2010b.

JAYME, Frederico; Crocco, Marco (Org). Bancos Públicos e Desenvolvimento. Rio de Janeiro: IPEA, 2010.

LAFER, Celso. A identidade internacional do Brasil e a política externa brasileira. Passado, presente e futuro. São Paulo : Perspectiva, 2001.

LAMPREIA, Luiz Felipe. Agenda para a Política Externa no Governo Dilma. Interesse Nacional, Ano 4, Edição 13, Abril a Junho de 2011. 
LANGEVIN, Mark. Gravity and Turbulence: United States-Brazil Relations under Obama and Lula. American Diplomacy. June, 2010.

MAIOR, Luiz A. P. Souto. A crise do multilateralismo econômico e o Brasil. Revista Brasileira de Política Internacional, n ${ }^{\circ} 47$ (2), 2004.

MINISTÉRIO DE MINAS E ENERGIA/ EMPRESA DE PESQUISA ENERGÉTICA. Plano Decenal de Expansão de Energia 2020. Brasília: MME/EPE, 2011.

MINISTÉRIO DE RELAÇÕES EXTERIORES. Balanço da Política Externa 20032010. Brasília, 2011. Disponível em: http://www.itamaraty.gov.br/temas/balanco-de-politica-externa-2003-2010

NYE, Jospeh S. Jr. Soft Power: The means to Success in the World Politics. New York: Pubic Affairs, 2004.

OCDE/FAO. Agricultural Outlook 2010-2019. OCDE, 2010.

PUTIN, Vladimir. Prepared Remarks at 43rd Munich Conference on Security Policy. Munchen, 10 de fevereiro 2007.

SILVA, Luiz Inácio Lula da Silva. Discurso durante cerimônia em comemoração ao Dia do Diplomata, Palácio Itamaraty, 20 de abril de 2010. Disponível em: http://www.info.planalto.gov.br/download/discursos/pr1793-2@.doc

SILVA, Luiz Inácio Lula da Silva. Discurso de posse no Congresso Nacional, 02/01/2003 disponível

http://prod.midiaindependente.org/pt/blue/2003/01/44633.shtml

TOLMASQUIM, Mauricio Tiomno, Guerreiro Amilcar, Gorini, Ricardo. Visão Prospectiva da Matriz Energética Brasileira: Energizando o desenvolvimento sustentável do país. Revista Brasileira de Energia, Vol. 13, N o 1, 2007.

UNCTAD. World Investment Report 2011. Non-Equity Modes of International Production and Development. UN, New York/Geneva, 2011.

VIOLA, Eduardo. A Política Climática Global e o Brasil: 2005-2010. Revista Tempo do Mundo, Vol. 2, N 2, Agosto 2010.

VIZENTINI, Paulo G.F. Relações Internacionais do Brasil: de Vargas a Lula. Editora Fundação Perseu Abramo, 2003. 


\title{
Giorgio Romano Schutte
}

\begin{abstract}
Brazil has the fifth largest population and territory, and is on its way to also becoming the fifth largest GDP in the world. It then should - in an active, creative way - be a leading country in the reorganization of the world's power system. It was under this prism that a strongly diplomatic presidency led President Luiz Inácio Lula da Silva to spend more than an eighth of his two mandates (2003-2010) abroad. This search to improve Brazil's position within international relations' hierarchy is linked to the strategies that occur in the national sphere. A discussion on the complex relationship between dependency and development resurfaced as an effort to formulate a neodevelopmentalist socio-economic policy. This paper highlights countries' capacity to react and organize around the 2008 global financial crisis, which was a significant time. From that time on, the world began to see Brazil differently, and to recognize the country's strategic resources, such as the new oil reserves, its environmental richness, and a unique potential to expand food production.
\end{abstract}

\section{KEYWORDS}

Brazil's foreign policy, developmental strategies, international relations 


\section{TEACHING AND RESEARCH ON FOREIGN POLICY IN THE FIELD OF INTERNATIONAL RELATIONS OF BRAZIL $^{1}$}

\section{Carlos Aurélio Pimenta de Faria ${ }^{2}$}

The status enjoyed by the Foreign Policy Analysis (FPA) as a sub-area of International Relations (IR), thought of as academic field, seems today, in the United States, no longer to be the object of so much controversy, as occurred in previous decades, when many expectations voiced by the original researchers of the sub-area (SMITH, 1986, reviewed these criticisms rightly) were frustrated. Today enthusiasm seems to prevail, among its supporters in academia, and it is visibly present in the work of Hudson (2005 and 2007). The revaluation of Foreign Policy Analysis was sanctioned in 2005 by launching a new journal devoted exclusively to the promotion of research in the sub-area, namely the Foreign Policy Analysis, published with the support of the ISA (International Studies Association). One will not find here an appraisal, albeit concise, of the sub-area evolution in the USA. To this end, the reader should refer to the work

\footnotetext{
1 The research that led to this work had the financial support of CNPq and FAPEMIG, whom the author wishes to acknowledge. The author also wishes to thank Luísa Gonçalves de Medeiros and Wilson Mendonça Júnior, by competent and dedicated research assistance. An earlier version of this paper was presented at the Third Meeting of the Association of International Relations (ABRI), São Paulo, USP, July $20^{\text {th }}$ to $22^{\text {th }}, 2011$. The author appreciates the comments and suggestions by Dawisson Belém Lopes and Haroldo Ramanzini Júnior.

${ }^{2}$ Professor at the Postgraduate program in Social Sciences and International Relations of the Pontifícia Universidade Católica de Minas Gerais (PUCMG, Brazil). (carlosf@pucminas.br)
} 
listed in the footnote ${ }^{3}$. The purpose of this article is solely to analyze teaching and research on foreign policy in Brazil in the last two decades.

To this end, the paper is organized as follows. The first section discusses how the main narratives about the evolution of International Relations in Brazil, considered as an area of knowledge, depict the place that has been designed, in the same area, to the study of foreign policy. The second section is devoted to an assessment of the status of foreign policy in IR teaching in the country, both at undergraduate and scricto sensu graduate programs. There is also a mapping and characterization of theses and dissertations which had foreign policy as object. The third section assesses the space given to studies on foreign policy in three academic forums nationwide, namely: the meetings of ABRI (Brazilian Association of International Relations), the ABCP (Brazilian Association of Political Science) and ANPOCS (National Association of Graduate Programs and Research in Social Sciences). In the fourth section there is a mapping and characterization of the published articles on foreign policy between 1990 and 2010, in the following IR Brazilian journals: Cena Internacional, Contexto Internacional, Política Externa and Revista Brasileira de Política Internacional. At last, the fifth and final section seeks to assess briefly the importance that comparative studies have in the sub-area of foreign policy in the country. The final considerations make a general assessment of the empirical research presented in the previous sections.

But first, we must define "foreign policy", distinguishing it from "international politics". It is also necessary to characterize, albeit briefly, the sub-area of Foreign Policy Analysis (FPA), with its specific characteristics in relation to the mainstream of $I R$, while recognizing the profound pluralization of the field in recent decades, in theoretic, methodological and thematic terms.

There are almost innumerable definitions of "foreign policy" found in the literature. That proposed by Arenal (1994) seems to us sufficiently precise in its brevity and will be adopted in this work:

${ }^{3}$ GERNER (1995); GROOM (2007); HILL \& LIGHT (1986); HUDSON (2005 and 2007); HUDSON \& VORE (1995); KAARBO (2003); KUBÁLKOVÁ (2001); LIGHT (1994); NEACK; HEY \& HANEY (1995); RIPLEY (1993); ROSATI (2004); and SMITH (1986). 


\section{Carlos Aurélio Pimenta de Faria}

"As foreign policy we must understand the study of how a State conducts its relations with other States, how it is projected to the outside, that is, the formulation, implementation and evaluation of foreign options from inside a State, under the perspective of the State" (p.22).

The author proposes that the definition of "international politics" also seems relevant, namely:

"The term international politics covers a wider reality than the foreign policy, since it refers not only to the action of a foreign State, but the set of interstate relations that constitute the system of States. Here the perspective is not a State, but this system as a whole". (Ibid.).

The IR field was split in the 1950s, according Kubálková (2001), into two sub-areas, namely: Foreign Policy Analysis (FPA) and the study of International Politics (IP). The question that promoted such divorce was the treatment given to the State, previously conceived as a "black box" whose contents would be of interest only to political science. The foreign policy analysts started to dedicate themselves to the opening of this "box" in order to understand the international behavior of States, which were taken as units of analysis. For its part, IP focused on the interaction among States in the formation of a system, in order to decipher their attributes. As it is clear from the two definitions given above, the first sub-area (FPA) favors the parts for a possible understanding of the whole, while the second (IP) departs from the whole to reach, sometimes, the parts. "Since the FPA 'has moved into the box", scholars from each side saw little need of each other and the two subfields began to grow separately" (KUBÁLKOVÁ, 2001: 15).

Even today such a dichotomous view of the area seems to prevail. As suggested by several authors, the "comparative studies of foreign policy (FP)", the "middle range theories" and "FP domestic sources" were for a long period the main approaches of the sub-area of Foreign Policy Analysis. For our interest in this work, the evolution of the subfield, which interspersed moments of optimism and euphoria with periods of low status, is less interesting than a characterization of FPA. This sub-area is characterized today by seeking to link the domestic and international arenas and the attempt to mobilize both levels 
of individual analysis, the State and the international system, trying to integrate them into a coherent whole (GERNER, 1995). So Roseneau defined it as a "bridging discipline", with "limitless boundaries" (GERNER, 1995). As it becomes evident, parsimony is not part of the vocabulary of the supporters of the FPA, which often contributed to the inferiority of the subfield within the academic context.

According to Hudson (2005), the FPA is characterized by its emphasis on "actor-specific focus", since the sub-area is backed on the argument that "everything that happens between nations and across them is grounded in human decision makers, acting individually or in groups" (p.1). Also according to Hudson, in another study (2007), FPA's approach would have six major hallmarks, which are: (1) it views the explanation of the decision making process as multifactorial, with the aim to examine variables over a level of analysis, being, therefore, (2) multilevel. (3) The multi- or interdisciplinarity, since insights and theories from various fields such as psychology, sociology, organizational theory, anthropology and economics, among others, are useful in the task of the FP analyst to explain the decision process. The FPA would then be, among all IR subfields, the more radically (4) "integrative" theoretical enterprise in that it seeks to integrate a variety of information across levels of analysis and spanning numerous disciplines of human knowledge (2007: 6). (5) Emphasis on "agent-oriented" theories. The States would not be agents, for they are "abstractions and therefore have no agency". (6) The theory of the FPA would also be "profoundly actor-specific" in its orientation, for the reasons given above.

The Post-Cold War FPA would have, still according to Hudson (2007), preserved their specific theoretical commitments that characterize the sub-area since its inception, the main ones being:

- "a commitment to look below the nation-state level of analysis to actor-specific information.

- a commitment to build middle-range theory as the interface between actor-general theory and the complexity of the real world.

- a commitment to pursue multicausal explanations spanning multiple levels of analysis.

- a commitment to utilize theory and findings from across the spectrum of social science. 


\section{Carlos Aurélio Pimenta de Faria}

- a commitment to viewing the process of foreign policy decisionmaking as important as the output thereof". (Hudson, 2007: 31)

Having done this very brief characterization of the sub-area of Foreign Policy Analysis, let us turn now to our appreciation of teaching and research on foreign policy in IR field in Brazil, following the structure presented above. Before, however, we anticipate, as we shall see in more detail at the end of the next section, that only part of the Brazilian academic production on foreign policy seems to fit this definition of the sub-area, its purposes, objects and methods.

\section{1 - Brazil's foreign policy seen through the large syntheses of the International Relations field in the country}

Remember, initially, that there are numerous works devoted to the study of evolution and characterization of IR field in Brazil ${ }^{4}$, which may reflect a need for (self) claim the area as a specific field of knowledge or, for many of the Brazilian internationalists, preferably an independent field. According to a more "benevolent" perspective, and certainly more accurate, it is possible to think the existence of this multiplicity of studies, perhaps unparalleled in Brazilian Social Sciences, as an expression of the very process of constitution of the field in the country, involving necessary activities like self-observation, selfreflection and self-description (CROSS;MENDONÇA, 2010). The present work is, too, part of this still ongoing process.

The IR area has, as it is known, a quite new constitution in the country, as evidenced by the expansion of undergraduate and graduate courses, which started in the mid-1990s and concentrated in the $2000 \mathrm{~s}$, and the creation of ABRI (Brazilian Association of International Relations) only in 2005, which held its first meeting in 2007.

The constitution of the area is, thus, late in Brazil, where the IR appeared in the academic, in close relationship with Political Science, as

\footnotetext{
${ }^{4}$ See, among others: ALMEIDA (1993 and 1999a and b); CRUZ \& MENDONÇA (2010); FONSECA JR (1989); HERZ (2002); HIRST (1992); LESSA (2005 and 2006); MIYAMOTO (1999 and 2003); SANTOS \& FONSECA (2009); SANTOS (2005); and SARAIVA \& CERVO (2005).
} 
occurred in the U.S., as highlighted by several authors, although the roots of the field are "planted in diplomatic history, the Public International Law and the corresponding branch of Economy." The IR gradually acquired its own identity and "its practitioners do not always recognize themselves as political scientists" (CROSS; MENDONÇA, 2010: 298).

It is not intended, in this section, to offer one more narrative, albeit synthetic, of the evolution of the field in Brazil. The goal, much simpler, is trying to determine how these great syntheses of the area in the country portray the meaning, relevance and development, in the field itself, of the study of foreign policy.

In its following sections, this work will be show the minority space occupied in recent years, in the academic realm of the IR of the country, by studies on foreign policy. However, a very different picture emerges from reading those works that sought to make an assessment of constitution of the field in Brazil, according to which, in past times, there was a predominance of studies on Brazilian foreign policy. Let us have a look at these works, following a chronological order:

"What marks, then, more generally, the 'Brazilian way' of thinking about international relations is the search of a specific understanding of the progress of foreign policy." (FONSECA JR., 1989:276)

“(..) the interest generated by new routes introduced in Brazilian foreign policy from the mid-70s in the academic world (...) was the main impetus for the development of IR area in the 70s. Nevertheless, the fact that this area focuses attention on the issue of State action itself leads to create a strong association between the development of the IR discipline and the study of Brazilian foreign policy." (HIRST, 1992: 66)

"From an examination of national production on the topics covered by the area of international relations (...) it is possible to reveal the dual character of the literature produced until the end of the 80s: the historical recovery and the prescription regarding the country's foreign policy. The main theoretical and epistemological debates that marked the development of the area studies in Europe, the 


\section{Carlos Aurélio Pimenta de Faria}

United States and other centers hadn't reached the Brazilian researchers until recently. This picture begins to change in the 90s." (HERZ, 2002:8).

"Still in the 90s, most of the academic production deals with international insertion of Brazil, the formulation of its foreign policy and the relevant bilateral ties, particularly with the United States and Argentina. The thematic distribution of master's and doctoral theses in the $80 \mathrm{~s}$ and 90s clearly demonstrates this fact (...) as well as publishing articles in journals. If we look at books publication, this reality is even more evident, since most of the national production refers to historical works on Brazilian foreign policy and international integration of the country" (HERZ, 2002:.23).

In this sense, Paulo Roberto de Almeida highlighted, in the late 1990s, though recognizing the interdisciplinary character of the area also in Brazil, that, in the field of IR in the country, it would be possible to see "a certain benign dictatorship of the history of international relations over other social science disciplines (sociology or political science), and over the applied social sciences (law, business administration or economics)" (1999a: 119, emphasis in original). In another study from the same time, the author says:

"(...) more reflective elaborations about the international
relations of Brazil derived mainly from Brazilianist
academic papers, without relevant theoretical contributions
by the Brazilian academy itself, despite the existence of
some great thinkers in the areas of political science and law
and 'Renouvinian' influenced researchers in the area of
history (especially at the University of Brasilia). From the
specific point of view of intellectual production in this area,
we can say that it evolved from the purely historiographic
school of the traditional era to the historical and
sociological essayism of the transitional period and even to
the more political markedly tone analysis of the recent
phase." (ALMEIDA, 1999b:194)

In a study of the mid-1990s, Amado Luiz Cervo, affirming that the study of IR in the country was a "thought without theory" and based on the international debate, was careful to distinguish the analytical work of historians 
from that of the political scientists by placing "spicing up" a debate that, in Brazil, remains strong until today. Another long quotation is in order here:

"The way historians do theory of international relations is quite distinct from the procedure of political scientists. The difference is the starting point: for the former, certain principles accepted as postulates which govern the deduction of knowledge: for the latter, the mass of accumulated knowledge by empirical research allowed the foundation of a reasoning process that is rather inductive. The theory of historians proved to be flexible and open to contributions from other social sciences and eventually freed the history from the nationalisms that pervaded the old diplomatic history. The theory of historians has another point of distinction with regard to that of their fellow scientists: it does not run after that secret, the key to the explanation of international relations". (CERVO, 1994: 13, emphasis in original).

We are not interested in reviving certain disputes, nor review them. The subsequent development of the historiography of Brazilian IR was synthesized by Lessa (2005), who ends his appraisal questioning the relevance of the judgment of Cervo (a "thought without theory") for the characterization of more recent periods. Santos (2005), in turn, in an article of the same year, argues, in the opposite direction, the subfield of the history of IR in Brazil, in the two previous decades, had little repercussion of the theoretical and methodological debates. When referring to the great synthesis made in História da Política Exterior do Brasil by Cervo \& Bueno, originally released in 1992 and reissued several times, perhaps still the most widely used textbook in undergraduate courses in the country, Santos states that (and also here there is no escape from a long quotation):

“(..) The authors, while making use of a methodology that favors multiple causes and the different analytical levels to understand the international insertion of Brazil and Brazilian foreign policy, identify State and nation and confuse the diplomatic discourse of Itamaraty with Brazil's own foreign policy. Thus, the history of international relations of authors is not, in fact, situated in a framework of general history, as Renouvin would say, economic and 


\title{
Carlos Aurélio Pimenta de Faria
}

social history, history of ideas and institutions; on the other hand, the State is identified as a unitary nation, neither multi-faceted nor problematized. In several parts of the work the authors make reference to the Brazilian State conforming to the interests of the "nation" (SANTOS, 2005: 26).

Listing, in the early 1990 s, the issues and problems that were previously overlooked or neglected by scholars of foreign policy of Brazil, Hirst (1992) mentioned, among others:

\begin{abstract}
"With regard to the domestic universe, there are various dimensions to be deciphered and subsequently incorporated into the study of Brazilian foreign policy. The analysis of decision making based on its societal base (pressure groups, values of the ruling elite, historical traditions, etc.), the institutional origins of foreign policy, the construction of its speech, are little explored perspectives in this direction. An important explanation for this lack is the addiction to globalizing perspectives that rarely focus on the analysis of specific aspects such as those just mentioned. They work with the notion of the State as a unified actor, which exerts a very simplistic effect, both to grasp the bureaucratic relationships and to realize the perception of dynamics that are established between the State bureaucracy and the living interests of society."(HIRST, 1992: 68-69).
\end{abstract}

It is clear that, if this situation started to change from the $1990 \mathrm{~s}$ onward, as noted by Herz (2002: 23), the 2000s witnessed a multiplication and diversification of the work of the sub-area, byproduct and at the same time feedback cause of the boom not only the IR area has lived in the country, but also the studies on foreign policy, as discussed in the subsequent sections of this work.

In our analysis of teaching and research on foreign policy developed in the last two decades, which follows, we have a double purpose: quantification and classification. The methods employed are presented below. It should, however, be said that the debate among historians and political scientists, which is obviously not regulated by the past $x$ present dichotomy, will be faced in a very peculiar way. The works of the sub-area are classified into two 
categories (Foreign Policy - FP and Foreign Policy Analysis - FPA), which, in turn, are subdivided as follows: (a) Brazilian foreign policy (BFP); (b) foreign policy of other countries (FPOC); (c) analysis of Brazilian foreign policy (ABFP); and (d) analysis of foreign policy of other countries (AFPOC).

If the FPA category was presented in greater detail in the introduction of this article, we will classify as FP studies those who embrace "globalizing perspectives", according to Hirst (1992), dedicated to the study of the major guidelines of the country's international insertion, on its more general aspects, with little concern for the domestic determinants of foreign policy and its decision-making process and that, and this point is central, face the State as a unitary actor. Note as well that this classification seems to innovate, for example, by giving a clearer sense of a category used by Herz (2002) in her survey and thematic classification of dissertations and theses in IR and papers in the area presented at ANPOCS during the 1980s and 1990s. This is because one of the categories adopted by the author is the "Brazilian Foreign Policy and International Relations of Brazil", which was, incidentally, the majority among the other themes distinguished by the author, both in case of completion of work and in studies shown at ANPOCS. It should be noted, however, that our FP category should not be understood as synonymous of "IR of Brazil", this last category that, in our judgment, would cover issues, problems and other actors beyond those involved in foreign policy, as defined in the introduction to this study.

It should be clear here that it is not intended, with this distinction between FP and FPA, to endorse any type dichotomy of traditional/modern or descriptive/analytical, although the present author considers it desirable to strengthen the Foreign Policy Analysis in the country, implying highlighting those "globalizing" trends aforementioned, which really seems to be already occurring, as discussed later. And also because it is recognized that, alongside the growing consolidation of Brazil's international relations and the increasing politicization of its foreign policy, it seems reasonable to expect that the analytical tools typical of the FPA, as it focuses on the domestic determinants of foreign policy, become increasingly important for understanding the country's international insertion. Note, however, that it is not unusual that the works that are more closely aligned with FPA, for focusing, sometimes excessively, on the domestic domain in its quest for understanding the 


\section{Carlos Aurélio Pimenta de Faria}

positioning of States at the international level, underestimate the systemic constraints that limit the autonomy of national decision makers, as indicated, for example, by Light (1994).

We also note that we recognize as problematic the inability of our classification of bringing to the fore, explicitly, the fundamental question of theory and method. However, we hope that what is lost in this sense is somehow compensated by the possibility, which such simplified option offer to us, of enlarging the scope of empirical research. Besides, of course, the possibility that it gives us to see to what extent the new generation of scholars of foreign policy is whether or not concentrated exclusively in the Brazilian experience, which is also a way to measure the maturity of not only the subarea, but also IR in Brazil themselves.

\section{2 - The foreign policy in the teaching of International Relations in Brazil}

This section of the paper is divided into two parts. At first, we analyze the space of foreign policy in the teaching of undergraduate and sricto sensu graduate programs in International Relations in Brazil. In the second part, we make a mapping and classification of research on foreign policy in the theses and dissertations of IR graduate programs in the country and also in the works available at Capes Database of Thesis and Dissertations ${ }^{5}$, covering all areas of knowledge.

\section{1-Foreign policy in undergraduate and graduate studies in International Relations}

The place now occupied by foreign policy in the field of Brazilian International Relations can be glimpsed, initially, through the way the sub-area has been addressed in the teaching of IR in the country, in the areas of undergraduate and graduate.

Usually one takes the expansion of IR graduate programs in the country, a phenomenon that has accelerated in the $2000 \mathrm{~s}$, as an indicator of the

\footnotetext{
5 Capes (Coordination for the Improvement of Higher Education) is an agency of the Brazilian federal government, under the Ministry of Education, responsible for promoting, regulating and evaluating graduation programs in Brazil.
} 
consolidation of the field in Brazil. In 2011 there were in the country 102 IR undergraduate courses registered on the Ministry of Education, the vast majority of which at private educational institutions (only 11 of these courses were offered by public universities). Out of these 102 degrees, we had access to the curriculum of 87 courses, in which are offered in 172 disciplines devoted to foreign policy, including mandatory, the overwhelming majority, and optional (only 10 of them are optional, but we had no information on this issue on 15 of these subjects) ${ }^{6}$. Among these 172 subjects are included those with a more historical approach, as well as those who favor diplomacy. It should be noted that only one of these courses does not offer any discipline focused on foreign policy.

To get an idea of the diversity of approaches and views, it is enough to say that these 172 subjects engaged in foreign policy are offered under 50 different denominations, being "Brazilian Foreign Policy" (BFP) the most common (38 subjects have such denomination). Other names frequently are, in descending order: "BFP I" (14 subjects); "BFP II" (14); "History of BFP" (13) and "History of IR in Brazil" (9). Thirty-three (33) subjects have unique names that are not repeated in other IR courses, such as: "Issues of BFP"; "Economic Diplomacy in IR"; "BFP's Military Regime" and "Diplomatic Contemporary Issues."

It is important to us here, however, to point out that seems correct to state that the sub-area of Foreign Policy Analysis still suffers, in Brazil, from an unsatisfactory a degree of institutionalization, at least when it comes to teaching. This is because, at undergraduate level, it is relatively rare to offer specific courses, distinct from the traditional discipline "Brazilian Foreign Policy" or "History of Brazilian Foreign Policy", both of which typically have more of a historical approach, dividing the subject according to presidential mandates and with an emphasis on diplomacy, owing as well to the traditional isolation of the country's foreign policy and Itamaraty. These are subjects in which the view of the State as a unitary actor is predominant.

${ }^{6}$ Sources: website of the Ministry of Education (MEC), www.e-mec.gov.br, accessed on May 18, 2011, websites of the institutions and mail exchange with the coordination of the courses. 


\section{Carlos Aurélio Pimenta de Faria}

Out of these 172 disciplines devoted to foreign policy at the undergraduate level, only 15 (or 24 if we include the 9 "Introduction to Foreign Policy" disciplines) seem more clearly connected to the sub-area of Foreign Policy Analysis, admittedly interdisciplinary, whose main goal is, as seen, to appraise the way the international position of States is produced from complex interactions between actors and institutions in domestic, state and non-state alike, taking into account their perception of the constraints and opportunities arising from the system internationally.

With regard to the graduate level, the outlook does not seem to be very different, even if, also in this context, the space devoted to foreign policy is significant. Out of the eleven IR graduate programs recognized by Capes $^{7}$ (as of mid 2011), only 3 were offered by private institutions, with only 3 that offer Doctoral Degree. Seven of the eleven programs had research fields devoted to foreign policy. In these eleven programs were offered a total of 26 subjects in the area of foreign policy, being only 6 of them mandatory (only one of eleven programs does not offer any discipline in the area). Among these 26 subjects, however, only three were called "Foreign Policy Analysis". When the syllabi of these 26 disciplines devoted to foreign policy are analyzed, what one finds is that, beyond 3 courses entitled Foreign Policy Analysis (all 3 electives), only 3 had other content that could be thought of as equivalent ${ }^{8}$. Put in another way, only 6 of these 26 subjects $(23 \%)$ emphasized the actors, the concerns and methods favored by the sub-area of Foreign Policy Analysis.

Moreover, as highlighted by Lessa (2005: 176), the latest IR Graduate Programs have "more multidisciplinary features", which may perhaps be

\footnotetext{
7 We chose not to include in the discussion that follows the master's course in "Strategic Studies of Defense and Security," offered by the Fluminense Federal University (UFF), and the major, master's and doctorate in "International Strategic Studies," offered by the Federal University of Rio Grande do Sul (UFRGS). The following are the 11 programs of graduate studies analyzed: CEBELA - Centro Brasileiro de Estudos Latino-Americanos (Rio de Janeiro, Master's, IR for South America); Rio Branco Institute (Brasilia, Professional Master in Diplomacy); PUC Rio (Master's and Doctoral Degree in RI); PUC Minas (Master's in IR); State University of Paraiba (Master's in IR); State University of Rio de Janeiro (MD in RI); Federal University of Rio Grande do Sul (Master's in IR); University of Brasilia (Master's and Doctoral Degree in IR); State University of São Paulo (Marilia, Master's in IR); University of São Paulo (Master's and Doctoral Degree in IR) and Federal University of Santa Catarina (Master's in IR) .

${ }^{8}$ Sources: website of Capes (<http://capes.gov.br/>), accessed on May 19, 2011, and websites of graduate programs on the Internet.
} 
thought of as potentially able to induce the development of investigations seeking to open the "black box" of the State, as intended by the FPA, which, as we have seen, demand, require and come from interdisciplinarity.

What seems clear is that, even today, the sub-area of foreign policy analysis tends to be slightly underprivileged even in the curriculum of graduate courses in International Relations in Brazil.

\section{2-Foreign policy in theses and dissertations}

A review of dissertations and theses produced in International Relations Graduate Programs (IRGP) of the country shows itself as revealing. We will discuss below the result of a research on this type of production in the eleven Graduate $P$ in IR we listed earlier. We consulted the websites of the programs and the Capes Database of Thesis. Note, however, that we count the papers that are available and not necessarily those actually defended within these 11 IRGP. Table 1 below presents a mapping and classification of theses and dissertations on foreign policy advocated in these programs (and available) between 1990 and 2010. It should be noted also that, for the reasons explained in the note to table, only the papers of 7 out of these 11 programs were counted.

The type of analytical treatment given to foreign policy in the theses and dissertations, ascertained through the title and abstract, method that we recognize as problematic, was classified according to our four categories: (a) Brazilian foreign policy (BFP); (b) foreign policy of other countries (FPOC); (c) analysis of Brazilian foreign policy (ABFP); and (d) analysis of foreign policy of other countries (AFPOC). The meaning and relevance of this distinction were discussed earlier. 


\section{Carlos Aurélio Pimenta de Faria}

\begin{tabular}{|c|c|c|}
\hline \multirow{4}{*}{ 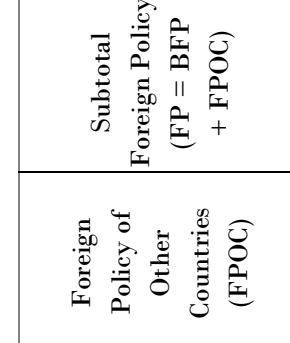 } & $a^{\circ}$ & $\begin{array}{l}\vec{b} \\
\text { oj } \\
\text { f }\end{array}$ \\
\hline & $z$ & $\approx$ \\
\hline & $\partial^{\circ}$ & \begin{tabular}{l}
$\infty$ \\
$\cong$ \\
\hdashline
\end{tabular} \\
\hline & z & $\stackrel{\infty}{=}$ \\
\hline 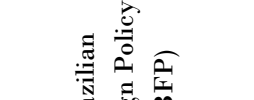 & $a^{\circ}$ & $\frac{\vec{n}}{\vec{n}}$ \\
\hline 9 & $z$ & $i s$ \\
\hline 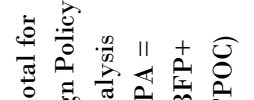 & $\partial^{\circ}$ & $\begin{array}{l}\text { Oे } \\
\text { is } \\
\text { in }\end{array}$ \\
\hline 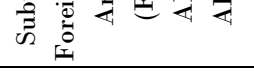 & $z$ & 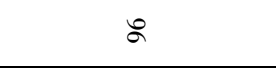 \\
\hline 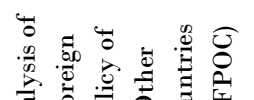 & $\partial^{\circ}$ & ஃั่ \\
\hline 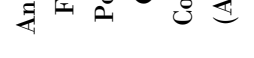 & z & $\stackrel{\circ}{\circ}$ \\
\hline 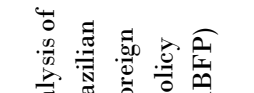 & $a^{\circ}$ & 苚 \\
\hline 邹 & z & 6 \\
\hline 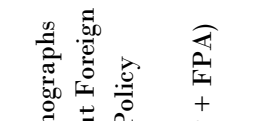 & $a^{\circ}$ & $\stackrel{8}{\circ}$ \\
\hline 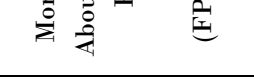 & z & $\underline{\sigma}$ \\
\hline 吾莺 & & 今े \\
\hline 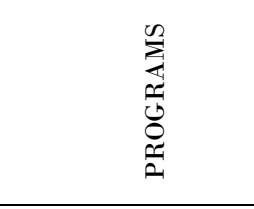 & & 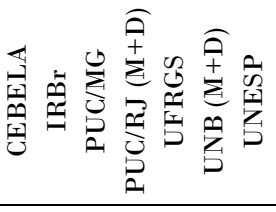 \\
\hline
\end{tabular}


First, to emphasize that, out of 809 theses and dissertations available, only 167 (or 20.64\%) were devoted to foreign policy. As we were unable to measure any differences between final papers that were effectively defended from those that were simply available, we will not make comparisons between programs. As shown in Table 1, the papers that we consider within the sub-area of Foreign Policy Analysis (FPA) prevailed, which represent 96 (or 57.48\%) of 167 theses and dissertations available on foreign policy. It is not surprising, of course, the fact that most of these 167 final papers on foreign policy were dedicated to the foreign policy of Brazil (BFP + ABFP) (comparative studies included here. See the fifth section of this article for an assessment of comparative foreign policy in the Brazilian academy). However, the fact that $53(35+18)$ of them $(31.74 \%)$ have as their object the foreign policy of other countries indicates that IR field in Brazil has formed internationalists who can hardly be regarded as self-centered ${ }^{9}$.

As the graduate programs in International Relations do not monopolize the studies on foreign policy, which should be thought of as positive, as we believe, we decided to check what Capes Database of Thesis could tell us. Table 2 below shows the results of research in this Database, which covers the period 1987-2009 and covers all areas of knowledge. From the search for the keywords "foreign policy" and "external policy" were reached, after the elimination of redundancies, the results of 588 theses and dissertations ${ }^{10}$. Remember that "167" is the number on the research did with IR Graduate Programs. It can be seen, therefore, that the vast majority of theses and dissertations on foreign policy were presented in programs other than the IR, which, in most cases, are quite recent. These final papers were not classified according to their approach

\footnotetext{
${ }^{9}$ Note, however, the warning made by Amorim Neto, who, however, does not seem fully appropriate for the type of study that we are mapping: “(...) which leads one analyst to the subfield of comparative politics [that author considers also incorporating analysis of only one other foreign country, like the way comparative politics in the U.S. is defined] is to see how generalizable are the relationships that are established from the observation of the politics of his country. In this sense, comparative politics is not overcoming the parochialism, but a validation method of what is observed in the parish. Parochialism and multinational comparisons have, therefore, a relationship of mutual dependence, as one does not exist without the other" (p.330).

${ }^{10}$ It should be noted that the fact that these terms have been selected by the author of the work as one of the keywords does not necessarily mean that the main focus of the study is foreign policy, which weakens the comparison we make afterwards, since the same note of caution does not apply to the selection of the work we did for final papers of IR Graduate Programs.
} 


\section{Carlos Aurélio Pimenta de Faria}

as we did in relation to theses and dissertations of IRGP. However, the subdivision of the accounted period (1987-2009) reveals that interest in foreign policy has been increasing, in a context, as we know, of great expansion of graduate programs in Brazil. It should be noted that the five year period from 2005-2009 concentrates more than 50\% of the work on foreign policy defended in 23 years under analysis. It is therefore a fairly recent phenomenon.

\section{Table 2}

Theses and Dissertations on Foreign Policy

(All areas - Capes Database - 1987 to 2009)

\begin{tabular}{|c|c|c|c|c|c|c|c|c|}
\hline \multirow{2}{*}{ Period } & \multicolumn{2}{|c|}{ Theses } & \multicolumn{2}{|c|}{ Dissertations } & $\begin{array}{c}\text { Professional } \\
\text { Master's }\end{array}$ & \multicolumn{2}{c|}{ Total } \\
\cline { 2 - 9 } & $N^{\circ}$ & $\%$ & $N^{\circ}$ & $\%$ & $N^{\circ}$ & $\%$ & $N^{\circ}$ & $\%$ \\
\hline 1987 to 1989 & 1 & $1,11 \%$ & 10 & $2,30 \%$ & 0 & $0,00 \%$ & 11 & $1,87 \%$ \\
\hline 1990 to 1994 & 7 & $7,78 \%$ & 34 & $7,83 \%$ & 0 & $0,00 \%$ & 41 & $6,97 \%$ \\
\hline 1995 to 1999 & 11 & $12,22 \%$ & 49 & $11,29 \%$ & 0 & $0,00 \%$ & 60 & $10,20 \%$ \\
\hline 2000 to 2004 & 29 & $32,22 \%$ & 113 & $26,04 \%$ & 26 & $40,63 \%$ & 168 & $28,57 \%$ \\
\hline 2005 to 2009 & 42 & $46,67 \%$ & 228 & $52,53 \%$ & 38 & $59,38 \%$ & 308 & $52,38 \%$ \\
\hline Total & 90 & $100 \%$ & 434 & $100 \%$ & 64 & $100 \%$ & 588 & $100 \%$ \\
\hline
\end{tabular}

Source: Own elaboration from Capes Database of Thesis, accessed on June 14, 2011.

$<$ http:/www.capes.gov.br/avaliacao/cadastro-de-discentes/teses-e-dissertacoes>.

\section{3 - The research on foreign policy in the Brazilian academic forums}

To evaluate the space given to the study of foreign policy, and also to International Relations in Brazilian academic forums about Social Sciences, we chose to analyze the scheduling of meetings of ABRI (Brazilian Association of International Relations), the ABCP (Brazilian Association of Political Science) and ANPOCS (National Association of Postgraduate Studies and Research in Social Sciences). It will be analyzed the schedule of 3 meetings already held by ABRI, which are biennial, all seven meetings of the ABCP happened until 2011, which are also biennial, and annual meetings of the ANPOCS happened

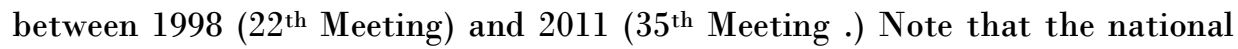
meetings of the ABCP occur in even years, while those of ABRI happen in odd 
years, which means that events do not "compete" directly with each other and it allows scholars and students to more easily attend both. This rotation is of the utmost importance when considering the need for cross-fertilization between the areas, which is particularly important in the case of research on foreign policy, at least for that sub-area affiliated to the Foreign Policy Analysis. We will analyze only the contents of the working groups, seminars and thematic areas and round tables, which are probably the most important events of such academic forums. Information was obtained from the websites of associations and printed programs of the meetings.

ABRI is the smallest and newest of the 3 associations. It was created in 2005 and held its first national meeting in 2007. In June 2011, ABRI had 484 members, divided as follows: full (183), professionals (82) and students (219) (data provided to author by ABRI). Note, however, that these data relate to the period immediately preceding the completion of its $3^{\text {rd }}$ meeting in July 2011. The number of members, as occurs in general, tends to increase significantly during the national meetings.

ABRI, naturally, gives the foreign policy since its inception, the same status granted to other subfields of the discipline since, in the Association, the field was divided, when its first meeting in 2007 in 6 thematic sections, namely: International Political Economy, International Institutions, Regional Integration, Foreign Policy, International Security, and Theory of IR. At the meeting in 2011, a new thematic area added to the previous (History of IR) and the International Institutions area became International Institutions and Organizations.

Any more systematic assessment of the evolution of the Association that focuses its national meetings is compromised by the fact that the second event was held in 2009 as a joint meeting between ABRI and ISA (International Studies Association). The achievement of this meeting together is, on the one hand, essential for the consolidation of the field in Brazil, and, on the other hand, it is also a complicating factor for a thematic and quantitative assessment of the evolution of ABRI. This is because in the first meeting were presented 190 papers in 47 panels. At the joint meeting of 2009, 1212 papers were presented in 233 panels. As to 2011, 507 papers were presented in 127 panels. Anyway, it is understood that the area, in general, has shown an 


\section{Carlos Aurélio Pimenta de Faria}

exponential growth, as reflected also by the expansion of graduate and postgraduate courses.

Because the 2009 meeting was so unusual, we will make only a comparison between the $1^{\text {st }}$ and $3^{\text {rd }}$ meetings. So what can be said is at the 2007 meeting, there were 8 round tables, but none of them focused on specific foreign policy. At the meeting in 2011, 5 roundtables held, one focused on foreign policy. It should be pointed out, too, that at the 2011 meeting, the Foreign Policy Thematic Area was the one that had the largest number of papers among the 507 presented - there were 107. The second area in terms of papers was Institutions and International Organizations, 85. The smallest of them, according to this criterion, was the International Political Economy, with 47 studies (data provided by the Association to the author).

ABCP, in turn, held its first biennial meeting in 1998. By 2011, 7 meetings were held, and, since its inception, the thematic areas covered expanded from 4 to 10. The Association had, in June 2011, 799 members ${ }^{11}$. Table 3 below presents a snapshot of space given to International Relations and foreign policy at all meetings of ABCP.

\section{Table 3}

International Relations and Foreign Policy in the meetings of ABCP

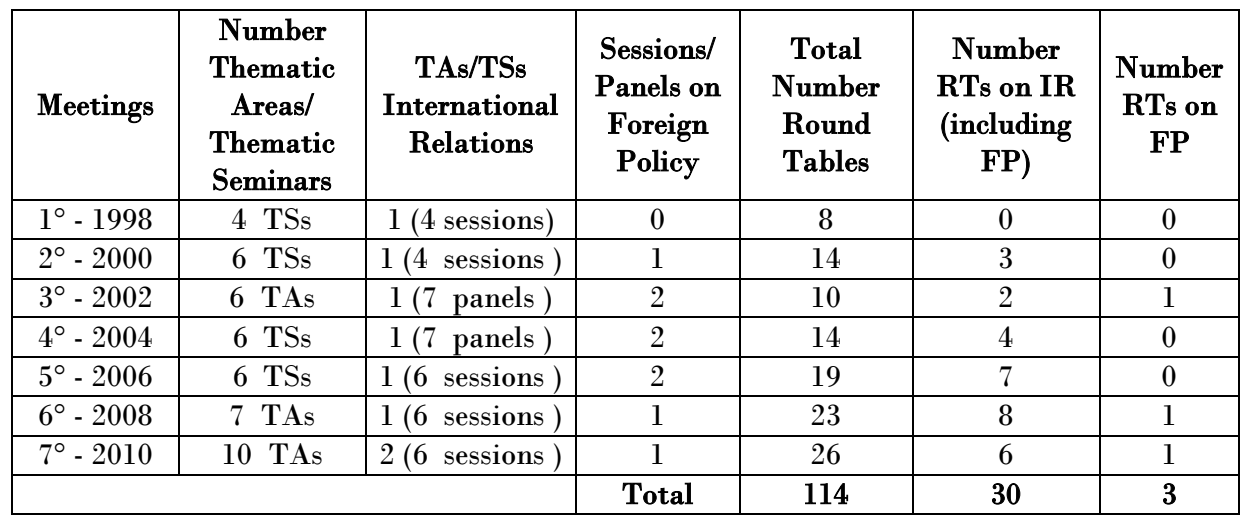

Source: Own elaboration based on printed programs of the biennial meetings and the Association website.

11 The ABCP provides on its website, a list of members. <http://www.cienciapolitica.org.br/abcp/socios_associados.html>. Accessed on June 27, 2011. 
Since the first meeting of ABCP, it had already established a Thematic Area (TA) of International Relations, which, in all meetings, has aggregated the research field. In the last meeting occurred in 2010, a new TA was created, one that also houses work in the area entitled Teaching and Research in Political Science and International Relations. Regarding the TA/TSs, thus, the space given to IR was constant until 2010, when it expanded. This is actually equivalent to a space dedicated to the major subfields of political science, for example, "Elections and Political Representation" and "Government and Public Policy." The same can be said in regard to the number of round tables dedicated to the IR (30 out of 114 , or $26.3 \%$ ), a significant number and also seems proportional to the key sub-areas and certainly greater than the space occupied by others. However, with respect to the space given to foreign policy, taken as a sub-area of $I R$, the result seems more ambiguous. If in the case of sessions/panels the space given to foreign policy seems proportionate to that enjoyed by other sub-areas of the IR, except for the first meeting, when there was a session dedicated to foreign policy, the number of round tables of the subarea FP is really low. Only 3 roundtables on foreign policy were conducted in seven meetings ( 3 out of 30 tables of IR, or 10\%).

Consider now the space given to IR and foreign policy at meetings of the ANPOCS (National Association of Postgraduate Studies and Research in Social Sciences). ANPOCS was established in 1977 and, according to its website, "acts in the representation and aggregation of research centers and postgraduate programs that operate in the field of social sciences in Brazil. ANPOCS has a membership of centers and programs that have postgraduate in anthropology, political science and sociology in their field"12. It was within ANPOCS that was created at the beginning of the $1980 \mathrm{~s}$, the pioneering group of International Relations and Foreign Policy (GRIPE), which "allowed the articulation of a network of experts originally dispersed throughout the country" (Hirst, 1992, p.71). This group acted under that Association until 1994 (MIYAMOTO, 1999).

\footnotetext{
12 Source: http://www.anpocs.org.br/portal/content/view/1/41/, accessed on June 21, 2011.
} 


\section{Carlos Aurélio Pimenta de Faria}

\section{Table 4}

International Relations and Foreign Policy at ANPOCS Meetings(1998-2011)

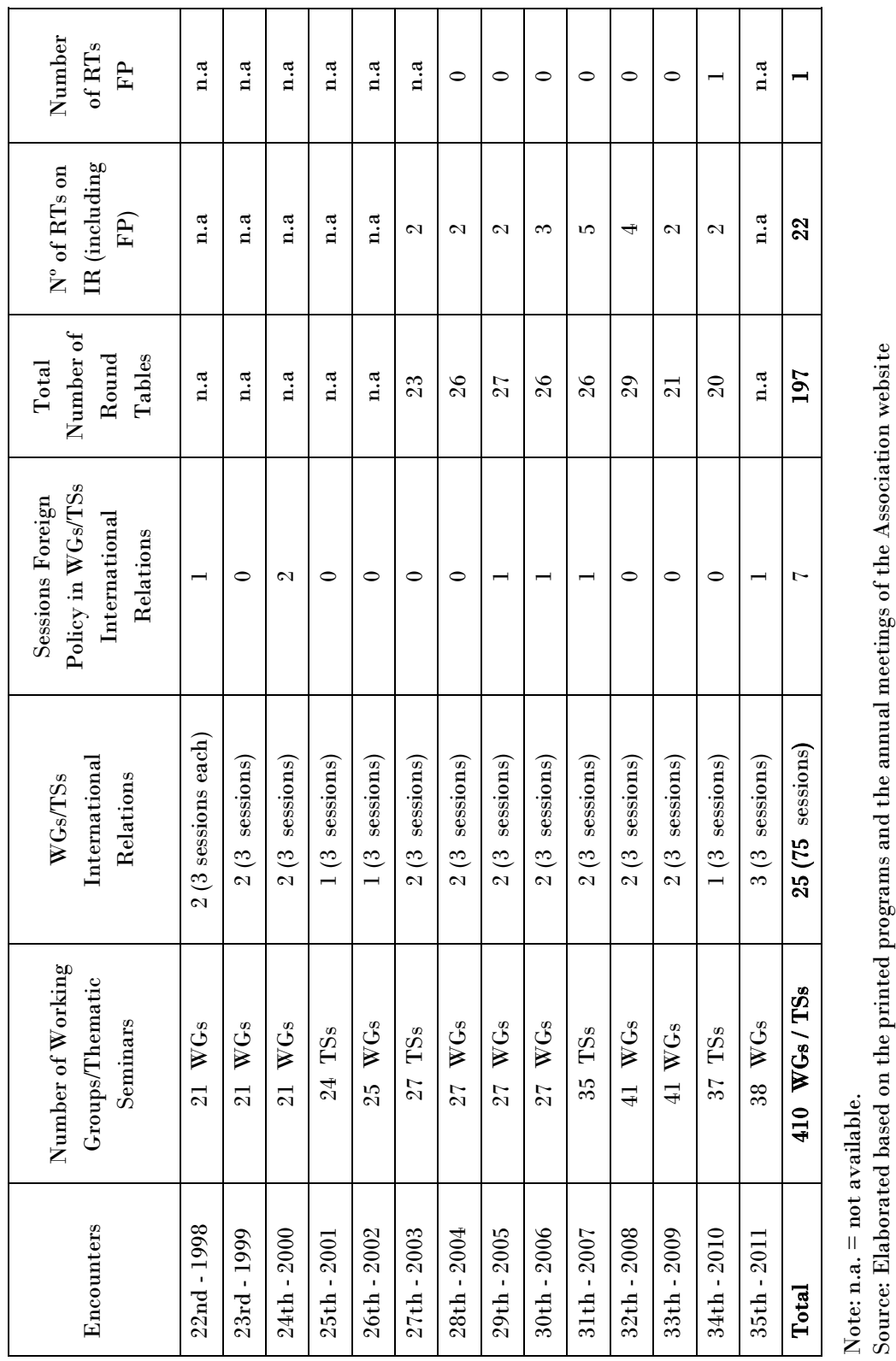


ANPOCS had, in June 2011, 99 research centers and postgraduate programs as members, 19 states of federation plus the Federal District. Table 4 below presents a snapshot of space given to IR and foreign policy in the 14 annual meetings that occurred between 1998 and $2011^{13}$. Being a much larger meeting than those made by ABRI and ABCP, because it is an association of a more clearly multidisciplinary vocation, several other types of activities take place, not only the Working Groups/Thematic Seminars and Round Tables, which are certainly among the main activities.

Initially, we note that, if the number of WGs/TSs has nearly doubled over this period, from 21 in 1998 to 38 in 2011, reflecting the expansion of postgraduate studies in Social Sciences in the country, the number of WGs/TSs dedicated to International Relations remained relatively constant over the period, which occurred in the boom of the IR in Brazil. As the area expanded so strongly in the period, one might think that the field has lost ground in ANPOCS or chose not to claim an extension of the place dedicated to IR. When one recalls that ABRI was established in 2005 and held its meetings in 2007, 2009 and 2011, it seems possible that we suggest that the constitution of the association of internationalists, certainly relevant and timely, if not responsible for the decline of "traditional" IR in the space of ANPOCS, did not contribute either to its expansion. From the standpoint of those interested in strengthening the Foreign Policy Analysis in Brazil, like this author, this development does not cease to be problematic in that the sub-area of the FPA, being openly multidisciplinary, requires the kind of cross-fertilization events provided by academic interdisciplinary as ANPOCS.

Continuing the analysis of Table 4, we should note that the space given to foreign policy remained scarce, despite the growing visibility and importance that this policy has taken in recent years, in Brazilian political agenda. In the 14 years analyzed there were only $7 \mathrm{FP}$ sessions out of the total 75 sessions that happened in the $25 \mathrm{WGs}$ /TSs of International Relations. Analyzing the Round Tables that took place in meetings about which information is available, we can highlight the following: out of the total of 197 RTs performed between 2003 and

\footnotetext{
13 The website of ANPOCS on Internet provides only the programs of the meetings that occurred between 1998 and 2011.
} 
2010,22 were dedicated to IR $(11.17 \%)$. However, in that same period there was only one conducted Round Table focused on foreign policy, which definitely does not reflect the increased visibility of the Brazilian foreign policy during Lula's administration, both at the political and societal plan and the academic one.

\section{4 - The foreign policy in the Brazilian academic journals in the field of International Relations}

In this section, we evaluate the frequency and type of treatment given to foreign policy in articles published between the years 1990 and 2010, for those who consider the main journals of Brazilian International Relations, which are, in alphabetical order: Cena Internacional, Contexto Internacional, Política Externa and Revista Brasileira de Política Internacional ${ }^{4}$. It should be stressed that important works devoted to the study of Brazilian and other countries' foreign policy have also been published by other journals of Social Sciences and Humanities of Brazil, which, however, were not covered by the mapping we present below.

The journal Cena Internacional has been published by the Department of International Relations at the University of Brasilia (REL-UnB) and by the Alexandre de Gusmão Foundation (FUNAG) since 1998. The biannual magazine is evaluated on CAPES Qualis ${ }^{15}$, in the area of Political Science and International Relations in 2011, as B2. The journal Contexto Internacional has been published by the Institute of International Relations at the Catholic University of Rio de Janeiro (IRI-PUC/RJ) since 1985. The journal is also biannual, classified as A2 in Qualis. The journal Política Externa is published by Paz e Terra Publisher, with the support of the International Conjuncture Group of the University of São Paulo (USP) and the Institute of Economic and

\footnotetext{
14 Lessa (2005) considered "unreasonably restrict" the number of specialized journals, "especially in scientific journals that support and promote debate in the area." Note also that the author doesn't consider the journal Política Externa as "scientific", but dedicated to "serving articles written by diplomats and businessmen in the form of high disclosure" (2005, p.177). Cross \& Mendonça, in turn, believe that the periodical is "one of the most important vehicles in the area," which is distinguished from other "by the extent of their movement and the diverse audience that reaches" (2010, p.309).

15 Qualis is the instrument developed by Capes, which evaluates and makes rankings of scientific journals.
} 
International Studies (IEEI) of the State University of São Paulo (UNESP). The publication has been published quarterly since 1992 and has the concept B2 in Qualis. The Revista Brasileira de Política Internacional (RBPI) has been published by the Brazilian Institute of International Relations (IBRI) since 1957. The journal is biannual its release, being rated as A2 in the CAPES Qualis.

The articles devoted to foreign policy published by these four academic journals have been mapped and classified according to their titles and/or reading their summaries, which is a method that we take as problematic, though it becomes legitimate when it is recognized that in this period (19902010) these journals published a total of 1347 articles. Book reviews, interviews, notes, documents, "expedient" and "passages" (biographical comments about personalities from academia and recently deceased politician, published in the journal Política Externa) were excluded from the analysis. There were 224 selected articles devoted to the study of foreign policy (or $16.63 \%$ out of the 1347 total articles published ${ }^{16}$ ), and these were classified according to the same four categories presented earlier, namely: (a) Brazilian foreign policy (BFP); (b) foreign policy of other countries (FPOC); (c) analysis of Brazilian foreign policy (ABFP); and (d) analysis of foreign policy of other countries (AFPOC).

The table 5 below presents the overview found.

${ }^{16}$ Journal Política Externa published, alone, nearly half of these 1347 articles (639 ou $\left.47.44 \%\right) . R B P I$ is the second, with $23.46 \%$ of them. 


\section{Carlos Aurélio Pimenta de Faria}

Table 5 - Foreign Policy in Major Brazilian Journals in the Area of International Relations (1990-2010)

\begin{tabular}{|c|c|c|c|c|c|c|c|c|c|}
\hline \multirow{2}{*}{ E } & de & œ̊ & $\begin{array}{l}\infty \\
\stackrel{\leftrightarrow}{\dot{*}}\end{array}$ & 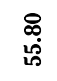 & 号 & $\begin{array}{l}\text { ज̆ } \\
\stackrel{0}{0}\end{array}$ & 赵 & 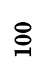 & \\
\hline & z & $\stackrel{2}{2}$ & के & 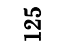 & ㄴํํ & F & 2 & స్ & \\
\hline \multirow{2}{*}{$\overline{\underline{2}}$} & de & 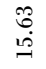 & $\vec{\sigma}$ & 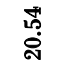 & $\stackrel{\text { ị }}{r}$ & $\begin{array}{l}\stackrel{0}{:} \\
\stackrel{\circ}{0}\end{array}$ & ثั & $\begin{array}{l}\stackrel{0}{0} \\
\stackrel{\oplus}{0}\end{array}$ & \\
\hline & z & $\stackrel{0}{\circ}$ & $=$ & $\mathscr{q}$ & $\cong$ & 0 & $\mathscr{N}$ & 8 & 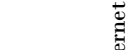 \\
\hline \multirow{2}{*}{ 牙在 } & $\partial^{\circ}$ & $\stackrel{ }{\stackrel{9}{9}}$ & 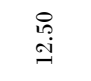 & $\begin{array}{l}\text { สุ } \\
\text { ஸึ }\end{array}$ & $\begin{array}{l}\vec{b} \\
D_{0}\end{array}$ & 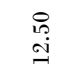 & $\begin{array}{l}\text { ปี่ } \\
\text { ஸे }\end{array}$ & 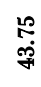 & \\
\hline & z & $\vec{N}$ & $\stackrel{\text { ๙ }}{ }$ & กี & $\stackrel{\infty}{=}$ & 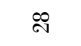 & to & $\approx$ & \\
\hline \multirow{2}{*}{ 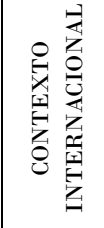 } & de & $\underset{\sim}{\stackrel{⿰}{N}}$ & $\begin{array}{l}\text { กึ } \\
\text { ลึ }\end{array}$ & 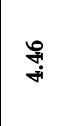 & $\stackrel{R}{6}$ & $\begin{array}{l}\tilde{L} \\
\stackrel{n}{L}\end{array}$ & సั & $\stackrel{\mathscr{T}}{ \pm}$ & \\
\hline & z & 10 & 10 & 오 & $\stackrel{20}{-}$ & $\infty$ & $\mathscr{N}$ & ๓ & \\
\hline \multirow{2}{*}{ : } & a & & $\stackrel{\mathscr{N}}{\stackrel{\sim}{N}}$ & :̊ํํ & $\stackrel{\Re}{\stackrel{\leftrightarrow}{i}}$ & - & $\stackrel{m}{\infty}$ & F & 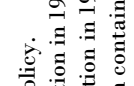 \\
\hline & z & $\mathcal{I}$ & 10 & 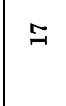 & 10 & $\sim$ & $r$ & ন & 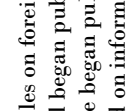 \\
\hline & & 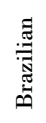 & 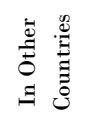 & 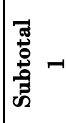 & صี & 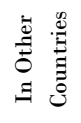 & 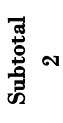 & \multirow{2}{*}{ 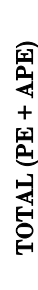 } & 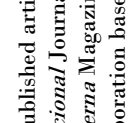 \\
\hline & & \multicolumn{3}{|c|}{ 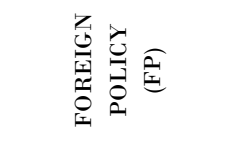 } & \multicolumn{3}{|c|}{ 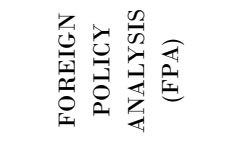 } & & 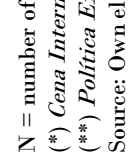 \\
\hline
\end{tabular}

The fact that the articles devoted to foreign policy totaling only 224 (16.63\%) of 1347 articles published by 4 journals between 1990 and 2010 is another indicator of the minority character of today's foreign policy in the IR field in Brazil. The analysis that follows is concentrated on these 224 articles. 
Most of them (125) were classified under "foreign policy" (FP) category. Articles in related with FPA sub-area are fewer (99). Those dedicated to Brazil (BFP + ABFP) totaled 131, while those focused on foreign policy of other countries (FPOC + AFPOC) totaled 93. Intuitively, we could imagine a greater difference. The fact of this difference not being so large suggests that the Brazilian internationalist community is not so self-centered (there are articles written by foreigners, of course, but their number is reduced ${ }^{17}$ ). Regarding the distribution of these 224 articles devoted to foreign policy under the 4 categories proposed here, the result is the following, in descending order: BFP (76 or $33.93 \%$ ); $\operatorname{ABFP}(55$ or $24.55 \%$ ); FPOC (49 or $21.88 \%$ ) and AFPOC (44 or $19.64 \%)$.

In total numbers, the journal Política Externa is the one that published the highest number of articles on foreign policy (FP + FPA) (98) and Cena Internacional the lowest (24). However, given the differences in frequency of the journals, the date of its publication and the number of articles published in each volume, the question is interesting to observe also taking into account the percentages of the total number of articles from all IR sub-areas, published by each journal. After doing the math, it is RBPI the one which published the highest percentage of articles on foreign policy (FP + FPA) (21.84\%). The others published, in descending order: Cena (16\%), PE (15.34\%) and Contexto $(13.64 \%)$.

The journal, in the period in question, that published the most about ABFP in absolute numbers was Política Externa (18), followed by RBPI (17). However, as a percentage of the total overall of published articles by each of the journals, the one that published the most about ABFP was Context $(6.2 \%)$, followed by $R B P I(5.38 \%)$.

Regarding the FPA (ABFP + AFPOC), the one that published the most, in absolute numbers, was Política Externa (46), followed by $R B P I$ and Contexto (tied with 23). As a percentage of total articles of each journal,

\footnotetext{
${ }^{17}$ It should be noted, however, that in survey of comparative politics in Brazil, Santos \& Coutinho (2002) analyzing 5 national journals of Social Sciences, among them only one of IR (Contexto Internacional), noted that "roughly $20 \%$ of publications on the analyzed journals are of foreign authors" (p.11). We did not do similar calculation in our work.
} 


\section{Carlos Aurélio Pimenta de Faria}

however, the one that published the most on FPA was Contexto $(9.5 \%)$, followed by $\operatorname{RBPI}(7.28 \%)$.

$R B P I$ is the journal that published the most BFP both in absolute numbers (35) and as a percentage of everything published in the period $(11.08 \%)$. When it comes to FP (BFP + FPOC), the most published in the period, in absolute numbers, was on Política Externa (52), followed by RBPI (46); whereas, as a percentage of all articles published in the journal, the one that published the most of FP was RBPI (14.56\%), followed by Cena $(11,33 \%)$.

So far, the situation was discussed for the period 1990-2010. So that we could get an idea of process, or evolution over time, the past decade has been divided into two periods of 5 years, which are: 2001-2005 (p1) and 2006-2010 (p2). When one considers the total number of articles on foreign policy (FP + FPA) published by the 4 journals that we are analyzing, there seemed to be an increase from 64 to 83 papers from $\mathrm{p} 1$ to $\mathrm{p} 2(+19$ articles). The largest growth was FP (BFP + FPOC), from 32 to 44 articles $(+12)$. The field of FPA (ABFP + AFPOC) increased in 7 studies (32 in p1 and 39 in p2). In 2006-2010 (p2), all four categories were improved, when compared with p1 (2001-2005): BFP from 21 to 25 articles $(+4)$; FPOC from 11 to $19(+8)$; ABFP from 15 to $20(+5)$ and AFPOC from 17 to 19 (+2 articles).

To end the section, it is appropriate to repeat the findings that $I$ consider most relevant. First, the fact that the space devoted to foreign policy in the 4 major IR journals in the country is almost peripheral (only 224 articles, out of 1347 published between 1990 and 2010, or 16.63\% of them). It is also significant that the articles that belong to the sub-area of Foreign Policy Analysis are fewer $(\mathrm{FPA}=99<\mathrm{FP}=125)$. When contrasting the periods 20012005 and 2006-2010, yet all our 4 categories have been expanded (BFP; FPOC; ABFP and AFPOC) the FPA sub-area grew less (FPA + 7 e FP +12). Also these indicators point to a weaker development of the sub-area of Foreign Policy Analysis.

Another interesting finding is the fact that, in the period 1990-2010, the number of articles devoted to Brazil's foreign policy (BFP + ABFP) wasn't much larger than those devoted to FP in other countries (131 x 93), which, as we suggest, may denote little self-centered or parochial character of Brazilian internationalists. 
A comparison of 4 journals between themselves reveals the following of most important: if the journal Foreign Policy published between 1990 and 2010 , the largest number of articles on foreign policy (FP + FPA) (98), was RBPI, which among the 4, published the highest percentage of works in the area $(21.84 \%$ of all articles that it published in the period). Both cases of FPA and ABFP, the journal that published more in the period, in absolute numbers, was Política Externa, which is quarterly, not biannual, as the other. However, in both cases, who published more FPA nad ABFP as a percentage of everything that was published was Contexto Internacional. Regarding the BFP, the journal that published more in absolute and relative terms was RBPI. As for FP (BFP + FPOC), who published more in absolute terms was the journal Política Externa, but as percentage this place was to $R B P I$.

\section{5 - The compared foreign policy on the Brazilian International Relations}

Depending on the relevance that the comparative study of foreign policy had, historically, on the conformation of the sub-area of Foreign Policy Analysis in the United States, originally formed as one of its pillars, we decided to also enjoy the use of comparisons on the works about foreign policy produced outside Brazil. Will be analyzed, then the theses and dissertations of IRGP and Capes Database, discussed in subsection 2.2 of this study, and articles on foreign policy published in 4 journals analyzed in Section 4, namely, Cena Internacional, Contexto Internacional, Política Externa and Revista Brasileira de Política Internacional (1990-2010).

By "comparative politics" we mean: (a) the study of similarities and differences between the courses of action adopted by two or more countries; and (b) the search for comparison within the same country, between governments or different periods, as well as among the treatment given by a single country or government to two or more foreign policy issues. This involves understanding the comparative politics as a field and not as a method. We recall here an important limitation of the survey presented below, made only by explicit mention in the title, the purpose of comparison. This method, known to be problematic, not capture, for example, those jobs, so common in the study of Brazilian foreign policy, seeking to analyze the famous "continuities and ruptures" promoted in this harvest, by different presidents. The method is sensitive to either "implicit comparisons" (AMORIM NETO, 2010). 


\section{Carlos Aurélio Pimenta de Faria}

Two previous studies have sought to map and characterize the comparative politics in the Brazilian Political Science, namely, Santos \& Coutinho (2002) and Amorim Neto (2010). The first one also addressed, albeit not systematic, the area of international relations, while the second chose not to incorporate. This second study, following the American tradition, defines comparative politics as "the politics of others", or the policy of "other people", whether made or not effective or explicit comparisons. If we adopt this definition, we would also incorporate the work which we classify as FPOC (foreign policy of other countries) and AFPOC (analysis of foreign policy of other countries), which won't be done here.

As seen in subsection 2.2 of this work, 809 theses and dissertations defended in International Relations postgraduate programs are available online. Of these, 167 (or 20.64\%) are devoted to the study of foreign policy. Among these 167, only 11 (or 6.59\% of the work on foreign policy) comparative studies can be considered according to the criteria presented above. A minority of them (5) compares the policies of two or more countries.

In the same subsection, we present the results of a survey, by keyword, made with Capes Digital Database of Theses and Dissertations. We recorded 588 works on foreign policy. Out of these, only 29 (or $4.93 \%$ ) were comparative studies, and the minority of them (10) sought to compare two or more countries.

Regarding the articles published by 4 major journals in the IR area of the country, we show in section 4 that during the period 1990-2010 were published totally 1347 works, out of which $224(16.63 \%)$ devoted to foreign policy. Out of these 224 , only 19 articles $(8.48 \%$ of the studies on FP) are comparative studies, being the minority (9) devoted to the comparison between countries.

What can be verified is the marginal character of compared foreign policy in Brazil, as opposed to what occurred as of the constitution of the subarea in the United States. Bear in mind, however, the limitations and inaccuracies of the method used here. These figures would be much higher if we had understood as comparative politics also monographic studies on other countries, such as the definition prevailing in the U.S. Having adopted different criteria from ours and incorporating in a less systematic way the IR area, besides being a work of the early 2000 s, Santos \& Coutinho said: 
"The field of comparative politics is poorly structured in the Brazilian academy. Although there is a significant number of papers, articles, theses and research projects that adopt a comparative perspective, there is not, in most major centers of research and postgraduate studies in Political Science and International Relations of the country, scientific coherently structured activities under this approach and not an institutional concern in developing the area. If we adopt the narrow conception of comparative politics, which requires reference to two or more countries, Brazilian scientific production reduces drastically. In fact, rarely Brazil compares with other countries. The comparisons are temporal. Brazil compares with Brazil." (2002: 5).

Amorim Neto, in turn, using different definitions and criteria, besides deleting International Relations from his analysis, concluded:

\begin{abstract}
"The intense dialogue with comparative theories is, indeed, a characteristic of Brazilian Political Science (...). So, if, regarding the explicit practice of comparative politics, the Brazilian situation gives no reasons for great optimism, with regard to the practice of implicit sub-discipline, the picture is more encouraging. Thus, Brazil applies perfectly well what Sartori said (...) in Italy: 'In Italy, multinationals comparativists, so to speak, aren't legion, but almost all of our political scientists are implicitly comparativists in the sense that its parameters are compared." (2010: 334).
\end{abstract}

\title{
6- Final considerations
}

Several recent studies have shown how the consolidation of Brazil's international relations has led to an increase in the redistributive impact, domestically, about the country's foreign policy, leading to an increased politicization of the policy, traditionally insulated and, sometimes, almost monopolized not too distant in the past by the Ministry of External Relations. The country's foreign policy mobilizes today, also because of the new international status of Brazil, a wide range of actors - societal and state alike in a process that has been defined as an increasing pluralization (see, for example, CASON; POWER, 2009 and FARIA, 2012). In this context, of 


\section{Carlos Aurélio Pimenta de Faria}

difficult reversion, which also reflects the profound changes that have passed the international system, foreign policy becomes the object of partisan and electoral dispute, priority for different interest groups and sub-national governments and the target of increasing intervention by part of the legislature, gaining increasing attention in the media.

If the study of foreign policy, as that of international relations themselves, has traditionally been guided by the situation in Brazil and elsewhere, it does not seem surprising the growing interest, in the Brazilian academic field of IR, in foreign policy. The fact that this sub-area is today minority in the IR of the country, unlike what occurred in previous decades, as shown by this work, should be seen as further evidence of the expansion and maturation of the field among ourselves.

If the studies of foreign policy, as sub-area of IR, have become minority in the country, as evidenced here, we believe that we have also demonstrated a significant change in this subfield, to the extent that, in several instances of which we reviewed, the typical investigations of Foreign Policy Analysis came to prevail. Such investigations, to refute the view of the state as unitary actor, by emphasizing the domestic determinants of foreign policy, by focusing on decision-making processes and institutional component of this policy, have mobilized an analytical instrument that seems more appropriate to understand Brazil's current international insertion. The pluralization of actors, who are involved and interested in foreign policy, has been followed by a similar pluralization not only in the centers of education and research in the country, but also in their objects, approaches and methods of analysis.

\section{REFERENCES}

ALMEIDA, Paulo Roberto de. (1993), "Estudo de relações internacionais do Brasil: etapas da produção historiográfica brasileira, 1927-1992". Revista Brasileira de Política Internacional, 36, 1: 11-36.

. (1999a), O estudo das relações internacionais do Brasil. São Paulo, Unimarco Editora. 
. (1999b), "Relações Internacionais". In: MICELI, S. (Org.). O que ler na Ciência Social Brasileira (1970-1995): Ciência Política (Volume III). São Paulo, Ed. Sumaré/ANPOCS.

AMORIM NETO, Octavio. (2010), “A política comparada no Brasil: a política dos outros". In: MARTINS, C.B. (Coord.), Horizontes das Ciências Sociais no Brasil: Ciência Política, São Paulo, ANPOCS/Ed. Barcarolla.

ARENAL, Celestino del.(1994), Introduccion a las Relaciones Internacionales. 3a edição, Madrid, Tecnos.

CASON, Jeffrey; POWER, Timothy. Presidentialization, pluralization, and the rollback of Itamaraty: explaining change in Brazilian Foreign Policy making from Cardoso to Lula. International Political Science Review. Vol. 30, No.2, p.117140. 2009.

CERVO, Amado Luiz. (1994), “As relações internacionais do Brasil”. In: CERVO, A.L. (org.). O desfio internacional. A política exterior do Brasil de 1930 a nossos dias. Brasília, Ed. UNB.

CERVO, A.L. \& BUENO, Clodoaldo. (2002), História da política exterior do Brasil.2a edição.São Paulo, Ed. Ática,

CRUZ, Sebastião C. Velasco e \& MENDONÇA, Filipe. (2010), “O campo das Relações Internacionais no Brasil". In: MARTINS, C.B. (Coord.). Horizontes das Ciências Sociais no Brasil: Ciência Política. São Paulo, ANPOCS/Ed. Barcarolla.

FARIA, Carlos Aurélio Pimenta de (2012). “O Itamaraty e a política externa brasileira: do insulamento à busca de coordenação dos atores governamentais e de cooperação com os agentes societários". Revista Contexto Internacional (no prelo).

FONSECA JR, Gelson. (1989), “Estudos sobre política externa no Brasil; os tempos recentes (1950-1980)". In: FONSECA JR, Gelson \& Leão, Valdemar C. (Orgs). Temas de política externa brasileira. Brasília, Ed Ática/IPRI.

GERNER, Deborah J. (1995), "The evolution of the study of foreign policy". In: NEACK, L.; HEY, J.A.K. \& HANEY, P.J. Foreign policy analysis. Continuity and change in its second generation. Englewood Cliffs, NJ, Prentice Hall.

GROOM, A.J.R. (2007), "Foreign policy analysis: from little acorn to giant oak?". International Studies, Vol.44, No.3, pp.195-215.

HERZ, Mônica. (2002), “O crescimento da área de relações internacionais no Brasil”. Contexto Internacional, 24, 1: 7-40.

HILL, Christopher \& LIGHT, Margot. (1986), "Foreign policy analysis". In: LIGHT, M. \& GROOM, A.J.R. (Eds.). International relations: a handbook of current theory, London, Pinter Publishers.

HIRST, Mônica. (1992), “Relações Internacionais no Brasil como área de pesquisa”. In: MICELI, S. (Org). Temas e problemas de Pesquisa em Ciências Sociais, São Paulo, IDESP.

HUDSON, Valerie M. (2005), "Foreign Policy Analysis: Actor-Specific Theory and the Ground of International Relations". Foreign Policy Analysis, 1, 1:1-30. 


\section{Carlos Aurélio Pimenta de Faria}

(2007), Foreign policy analysis: classic and contemporary theory. Lanham, Maryland, Rowman \& Littlefield Publishers.

HUDSON, Valerie \& VORE, C.S. (1995). "Foreign policy analysis yesterday, today, and tomorrow". Mershon International Studies Review, 39:209-238.

KAARBO, Juliet. (2003), "Foreign policy analysis in the Twenty-First Century: back to comparison, forward to identity and ideas". International Studies Review, 5, 2:156-163.

KUBÁLKOVÁ, Vendulka. (2001), "Foreign policy, International Politics, and Constructivism". In: KUBÁLKOVÁ, V. (org.). Foreign policy in a constructed world. New York, M.E. Sharpe.

LESSA, Antônio Carlos. (2005), "Instituições, atores e dinâmicas do ensino e da pesquisa em Relações Internacionais no Brasil: o diálogo entre a história, a ciência política e os novos paradigmas de interpretação (dos anos 90 aos nossos dias)". Revista Brasileira de Política Internacional, 48, 2: 169-184.

- (2006), "A intensificação do debate acadêmico e social sobre relações internacionais e política exterior no Brasil" In: LESSA, A.C. \& OLIVEIRA, H.A. (Orgs.). Relações internacionais do Brasil: temas e agendas. Vol.2. São Paulo, Ed. Saraiva.

LIGHT, Margot. (1994), "Foreign policy analysis". In: GROOM, A.J.R. \& LIGHT, M. (Eds.). Contemporary international relations: a guide to theory. London, Pinter Publishers.

MIYAMOTO, Shiguenoli. (2003), “O ensino das relações internacionais no Brasil: problemas e perspectivas". Revista de Sociologia e Política, 20:103-114.

. (1999), “O estudo das relações internacionais no Brasil: o estado da arte". Revista de Sociologia e Política, 12: 83-98.

NEACK, Laura; HEY, Jeanne A.K. \& HANEY, Patrick J. (1995), Foreing policy analysis. Continuity and change in its second generation. Englewood Cliffs, N.J., Prentice Hall.

RIPLEY, Brian. (1993), "Psychology, foreign policy, and international relations theory". Political Psychology, 14, 3: 403-416.

ROSATI, Jerel A. (2004), "The frustrating study of foreign policy analysis". International Studies Review, 6:109-111.

SANTOS, Norma Breda dos \& FONSECA, Fúlvio Eduardo. (2009), “A pós-graduação em relações internacionais no Brasil”. Contexto Internacional, 31, 2: 353-380.

SANTOS, Norma Breda. (2005), "História das Relações Internacionais no Brasil: esboço de uma avaliação sobre a área". Revista História (São Paulo), 24, 1: 11-89.

SANTOS, Maria Helena Castro \& COUTINHO, Marcelo J.V. (2002), "Política comparada: estado das artes e perspectivas no Brasil". BIB - Boletim Informativo e Bibliográfico em Ciências Sociais, 54: 5-44.

SARAIVA, José Flávio S. \& CERVO, Amado Luís (Orgs.).(2005), O crescimento das Relações Internacionais no Brasil. Brasília, IBRI.

SMITH, Steve. (1986), "Theories of foreign policy: an historical overview". Review of International Studies, 12,1:13-29. 


\begin{abstract}
The purpose of this article is to analyze teaching and research on foreign policy in Brazil in the last two decades. The first section discusses how the main narratives about the evolution of International Relations in Brazil, considered as an area of knowledge, depict the place that has been designed, in the same area, to the study of foreign policy. The second section is devoted to an assessment of the status of foreign policy in IR teaching in the country, both at undergraduate and scricto sensu graduate programs. There is also a mapping and characterization of theses and dissertations which had foreign policy as object. The third section assesses the space given to studies on foreign policy in three academic forums nationwide, namely: the meetings of ABRI (Brazilian Association of International Relations), the ABCP (Brazilian Association of Political Science) and ANPOCS (National Association of Graduate Programs and Research in Social Sciences). In the fourth section there is a mapping and characterization of the published articles on foreign policy between 1990 and 2010, in the following IR Brazilian journals: Cena Internacional, Contexto Internacional, Política Externa and Revista Brasileira de Política Internacional. At last, the fifth and final section seeks to assess briefly the importance that comparative studies have in the sub-area of foreign policy in the country. The final considerations make a general assessment of the empirical research presented in the previous sections.
\end{abstract}

\title{
KEY WORDS
}

International Relations; Foreign Policy; Brazil

*Translated by Gabriela Perin 


\title{
BRAZIL IN FACE OF THE CHINESE RISE: THE RISKS OF REGRESSIVE SPECIALIZATION ${ }^{1}$
}

\author{
André Cunha ${ }^{2}$, Marcos Lélis ${ }^{3}$, Julimar Bichara ${ }^{4}$, Manuela de \\ $\operatorname{Lima}^{5}$
}

\section{Introduction}

During the first decade of the $21^{\text {st }}$ century, China consolidated its position as the world's second largest economy in terms of its product, international trade and property of financial assets abroad ${ }^{6}$. Not even the global financial crisis, originated in the U.S. mortgage market in 2007 and whose consequences are felt until today, was able to stop its upward trend ${ }^{7}$. The most influential projections about the evolution of global economy suggest that China will, in a not too

\footnotetext{
${ }^{1}$ This paper was developed from researches funded by CNPq (Process Number 200238/2011-6) and Celso Furtado Center of Policies for Development (Announcement 02/2011). The opinions here expressed do not, necessarily, coincide with the vision of authors' institution of origin.

${ }^{2}$ Professor of the Economics Graduate Program/UFRGS and International Strategic Studies Graduate Program/UFRGS. Researcher of CNPq. Email: andre.cunha@ufrgs.br

${ }_{3}$ Professor of Unisinos and Coordinator of APEX-Brazil Unity of Commercial and Competitive Intelligence. Email: mcaputi@uol.com.br

${ }^{4}$ Professor of the Autonomous University of Madrid (Spain). Email: julimar.dasilva@uam.es.

5 Analyst of APEX-Brazil Unity of Commercial and Competitive Intelligence. Economics Graduate Program/Unisinos Masters student. E-mail: manuela.lima@gmail.com

${ }^{6}$ See Timmer et al. (2012), Morrison and Labote (2011).

${ }^{7}$ Breslin (2011) provides an updated review on the nature of the "Chinese model". See also Zheng Bijian (2006), Kang (2007), Naughton (2007), Kurlantzick (2007), Halper (2010), Kissinger (2011), Leão, Pinto and Acioly (2011).
} 
distant future, overcome the U.S., positioning itself as the largest economy in the world ${ }^{8}$.

Experts in political science and international relations tend to evaluate such dynamic in terms of its impacts on the power structure at global level (BRESLIN, 2011; VISENTINI, 2011). There are those who fear that the contemporary China reproduces historical situations in which rising powers such as Japan and Germany between the end of the $19^{\text {th }}$ century and the first decades of the $20^{\text {th }}$ century - sought to change the status quo, which resulted in destabilizing process and wars $^{9}$. There are, obviously, those who imagine that China will be a well-behaved actor of the liberal order created on the post-war ${ }^{10}$. Still in the framework of this debate has taken shape the duality between the supposed American decline and the strengthening of the Asian power.

Chinese experts and sinologists of the Western academy argue that China's rise will be peaceful and the country is far from replacing the U.S. as a hegemonic power. They glimpse a multipolar international order and with a greater sharing of responsibilities (KANG, 2007; ZHENG BIJIAN, 2005; WU JIGLIAN, 2005, 2006; HU ANGANG, 2010). They point out to weaknesses in the Chinese political-institutional structure and its economy, particularly the low capacity to generate technological innovations, the deterioration of the environment and the pattern of income distribution, sub-products of the model of accelerated growth. They even question the capacity to legitimate the

\footnotetext{
${ }^{8}$ See, among others, Goldman Sachs (2007), National Intelligence Council (2008), Cepal (2011a) and Timmer et al. (2012).

${ }^{9}$ Subramanian (2011) and Halper (2010) show that the risks of China overtaking the U.S. are high, either by virtue of their own, or by increasing economic and political fragility of the current superpower. And this could happen in an environment of increasing conflict as suggested by Mearsheimer (2010). To Halper (2010) the main risk comes from the international projection of the Chinese model, where they combine the strong centralization of political decisions in an authoritarian State with an aggressive adherence of market mechanisms in the world of production, marketing and finance. In turn, Subramanian (2011) emphasizes the weaknesses of the Americans, potentiated after the crisis: excessive debt, growing concentration of income, depletion of the middle class and the inability of the political system to provide solutions to economic problems. Still, others consider that the Chinese power and its prospects in the coming decades have been over-estimated (Babones, 2011; Clark, 2011).

${ }^{10}$ U.S. analysts envision the possibility of China working alongside the U.S. to face global problems. The maintenance of a democratic and open order would pass, on one side, by the U.S. ability to recover the ability to influence the emerging powers by non-aggressive mechanisms and, secondly, by their provision to act to strengthen institutions and global public assets. See: Nye Jr (2011), Kissinger (2011) and Ikenberry (2011).
} 
current power structure and, consequently, its possibility to ensure a path of social stability in the context of an economy increasingly governed by market mechanisms. The "fragile superpower" (SHRINK, 2007) would be surrounded by internal and external problems that would derail its capacity to project power internationally in the same way that the United States do.

This more general debate serves as a background to what is the focus of this article, namely, to explore some implications of China's rise on the recent development trajectory of Brazil. More specifically, we seek to map some of the risks associated with the pattern of economic interaction that has been consolidating in the Sino-Brazilian relations, in which, on the one hand, Brazil has emerged as a producer and exporter of natural resources and, on the other hand, China intensifies its presence as an exporter of manufactured goods and capital. Our main hypothesis is that the consolidation of this pattern tends to impose non-negligible risks of crystallization of a regressive specialization framework (COUTINHO, 1997; JAYME JR; REZENDE, 2009) to Brazil, in which it is possible to see the loss of density, diversity and vitality of the productive structure and the pattern of commercial insertion. To counter this trend, the country will need to recover the capacity to adopt coherent and powerful development policies, whose general characteristics will be explored at the end of this work.

Our arguments are structured as follows. After this short introduction, section 2 recovers the recent debate about the development, in which it is emphasized the success of Asian economies. It is highlighted that this success is rooted on the diversification of the structure of production and international trade, whereas other peripheral regions showed loss of dynamism. Section 3 provides a set of empirical evidence that suggests that Brazilian economy, as well as other peripheral economies, is increasingly linked to the Chinese economy in a typical pattern of North-South relation. Section 4 gathers the key conclusions and explores their implications in terms of policymaking.

\section{Development in Perspective: the international experience compared}

The perception that government activism is directly associated to economic progress of nations goes back, at least, to the period of mercantilism (REINERT, 1999; 2007). The argument of protection of the infant industry of 
Alexander Hamilton and Friedrich List became popular in emerging nations seeking to reproduce the British trajectory of industrial revolution (CHANG, 2002). Likewise, the notion that economic development entails a qualitative change in production structures, where technological innovations find a central role, is strongly grounded in the work of Schumpeter and resonates in Marx's analysis.

Writers such as Joan Robinson, Kaldor, Pasinetti, Thirlwall, among others, based on the insights of Keynes, Kalecki and, to a lesser extent, Marx, showed that the growth process is centered on the accumulation of capital without being, necessarily linear, tending to balance or able to, through market mechanisms, produce a socially fair pattern of expansion. Moreover, in opposition to the neoclassical models, it is emphasized the centrality of the manufacturing industry, considered as the bearer of the growth-enhancing properties (TREGENNA, 2009; PALMA, 2007; 2011). The so-called Kaldor's laws of growth clearly express this. Thus, for this author: (i) there would be a direct relationship between the growth of industry and growth of the economy as a whole - the "first law"; (ii) productivity growth in industry would be an endogenous phenomenon to the expansion of this sector, given the static and dynamic economies - "second law" or "Verdoorn law"; and (iii) the higher productivity in the industry is, the greater productivity of non-industrial sectors is. Moreover, Kaldor and Thirlwall realized that there would be a limiting long-term expansion associated with differences in income elasticities of imported and exported products, in line with the arguments of Furtado (2003) and Prebisch (1984).

Furthermore, historical experience of the interwar represented a decline of liberal strategies, with the subsequent rise of State activism, necessary to enable the restructuring of economies after the 1929 crisis, the war effort and the later reconstruction. The independence movements in Africa and Asia from the second half of the 1940s and the insights of the theorists of development ${ }^{11}$ stimulated the modernization effort, in which nation-building

\footnotetext{
11 To this period authors as Rosentein-Rodan, Nurkse, Hirschman, Prebisch, as well as economists of the "Cambridge school" (Tregenna, 2009, Palma, 2007 and 2011), as Kaldor, Robinson, Pasinetti, among others, are essential references. Krugman (1993) called this period of "high development theory", whose
} 
was mixed up with the idea of industrialization. In this context, the debate on economic development has polarized positions between those who favor and those who criticize the idea that market mechanisms are sufficient to ensure a sustainable and balanced growth. Among the critics there is a perception that the State has a crucial role in the induction and, in certain circumstances, in the command of the development process. They argue that State action is directly proportional to: (i) the markets' weaknesses and shortcomings, and (ii) the relative delay of each country in face of the techno-productive frontier. This would explain the greater economic presence of State in late development countries. Moreover, this tradition suggests that industry is vital for growth and nations can build competitive advantage through industrial policies.

The pro-market view has been supported by mainstream of professional economists and the most influential multilateral organizations like the IMF and World Bank (WB). It is emphasized that the market is the institution that ensures more efficiency on allocation of scarce resources. The freely determined prices in the markets would signal the relative scarcity of factors of production and, thus, would indicate the patterns of productive specialization. It is suggested that productive and trade specialization, in line with comparative advantages derived from the relative factor allocation, would maximize the allocative efficiency and, therefore, the growth potential. Countries that are rich in natural resources should specialize in these sectors. The supply of other goods would come through exports. To counter such a standard, through industrial policies, would lead, ultimately, to a waste of resources, corruption, and fiscal and monetary imbalances.

Since the postwar period, the industrialization experience of peripheral economies has been the backdrop for the clarification of these positions. In particular, the successful case of sustained growth of Asian countries $^{12}$ became the center of major controversy, as they began to detach

pioneering had insights later incorporated into the "new economic geography", in endogenous growth models and the new trade theory.

12 The recent study commissioned by the World Bank (World Bank, 2008) and led by two Nobel Prize winners in Economics, Robert Solow and Michael Spence, sought to identify success stories (and its explanations) of high and sustained growth in the period that followed World War II. There were 13 countries to grow more than $7 \%$ a year for over 30 years, out of which 9 were nations of Southeast and 
from the other peripheral regions in terms of growth, and income and world exports share, as well as structuring of the more diverse and complex production bases than those observed in other regions. And this process took place with those countries departing from a base of economic and social development lower than that observed in Latin America in general and, even, in many African countries (CHANG, 2006).

In 2010, the Asian-Pacific countries represented $55 \%$ of world population, $34 \%$ of income and $30 \%$ of exports. The dynamism of Asia in the period of globalization opened in the last quarter of the $20^{\text {th }}$ century can be expressed as follows: if, in 1980, Latin America accounted for 11\% of global GDP measured in dollars adjusted through purchasing power parity, Asia (excluding Japan) reached 9\%. Three decades later, Latin America had 8.5\% of global GDP, while Asia reached 28\%. While Asian countries grew at average rates of $7 \%$ per year, the Latin American and African countries experienced much lower rhythms, between $2 \%$ and $3 \%^{13}$. From the point of view of foreign direct investment absorption, the Asian (excluding Hong Kong) more than double its space between the years 1980 and $2010^{14}$. On the other hand, economies that have developed their national innovation systems and constituted internationally competitive companies generally have lower levels of participation of foreign capital, cases of Japan, South Korea and Taiwan ${ }^{15}$.

The era of globalization resulted in the incorporation into the international market circuits of economies, which until then, had kept limited

East Asia (Japan, Hong Kong, Taiwan, South Korea, Singapore, Malaysia, Indonesia, Thailand and China). Brazil, in the 1950-1980 period, is also in this group.

13 See IMF World Economic Outlook, September, 2011. <http:/www.imf.org/external/pubs/ft/weo/2011/02/index.htm>. Accessed on March 21, 2012.

${ }^{14}$ Between 1980 and 2010 the world stock of FDI (inward) went from $\$ 700$ billion to $\$ 19.141$ billion. In 1980, developed countries held $57 \%$ of that stock, against $43 \%$ of developing countries. In 2010 these contributions were respectively $65 \%$ and $35 \%$. On the other hand, the Asian economies, excluding Hong Kong, rose from $5.2 \%$ to $13.4 \%$ of world total. <http://www.unctad.org/en/Pages/Publications/WorldInvestmentReports(1991-2009).aspx. Accessed on March 21, 2012.

15 In 2010, the FDI/GDP coefficient was: $30 \%$ in developed economies, $29 \%$ in developing economies, $26 \%$ in Asia, 33\% Africa, and 34\% in Latin America. However, in the most dynamic Asian economies this indicator was much smaller than that observed in other economies with similar per capita income: $4 \%$ in Japan, $13 \%$ Korea and $14 \%$ in Taiwan. In China it was $10 \%$.<http:/www.unctad.org/en/Pages/Publications/WorldInvestmentReports(1991-2009).aspx>. Accessed on March 21, 2012. 
interaction ties with the rest of the world. Countries of the former socialist bloc and several nations in the periphery become, simultaneously, spaces of production and markets for goods, services and factors of production, particularly capital. Clearly, Asian economies can be identified as those that emphasized an insertion based on the production and export of industrial goods, which, in a Keynesian-Kaldorian perspective, tends to contribute to its superior performance in terms of GDP growth and productivity. Figure 1 reports the participation of major economies in the region, excluding Japan, which is the G7 cluster, in the world production of manufactures. In 1980, Asia accounted for $4.4 \%$ of the world total, below the participation of major Latin American economies, 6.7\%. In 2010, the Asian participation rose to $27.2 \%$ and the Latin American shrank to 5\%. The most advanced economies (G7) and the rest of the world also experienced the relative loss of importance of its industrial production.

Chart 1. Distribution of world industrial production, 1980-2010 (value added in processing industry in \%).

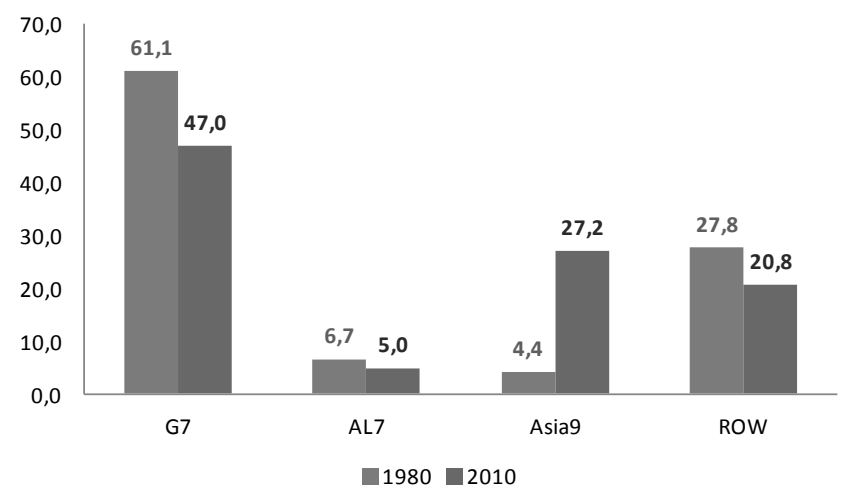

Source of raw data: United Nations National Accounts Main Aggregates Database $<$ http://unstats.un.org/unsd/snaama/introduction.asp>. Accessed on March 3, 2012.). G7 - U.S., GB, Japan, Germany, France, Italy and Canada; AL7 - Argentina, Brazil, Chile, Colombia, Mexico, Peru and Venezuela; Asia9 - China, Hong Kong, South Korea, Malaysia, Indonesia, India, Thailand, Philippines and Singapore; ROW - rest of the world.

Chart 2 suggests that, until the mid-1970s, the major developing economies of Asia and Latin America held similar shares of world exports. However, while the Asian economies quadrupled its market-share, the Latin American economies remained roughly in the same situation. 
Chart 2. Participation of Selected Economies in World Exports of Goods, 1948$2010(\%)$

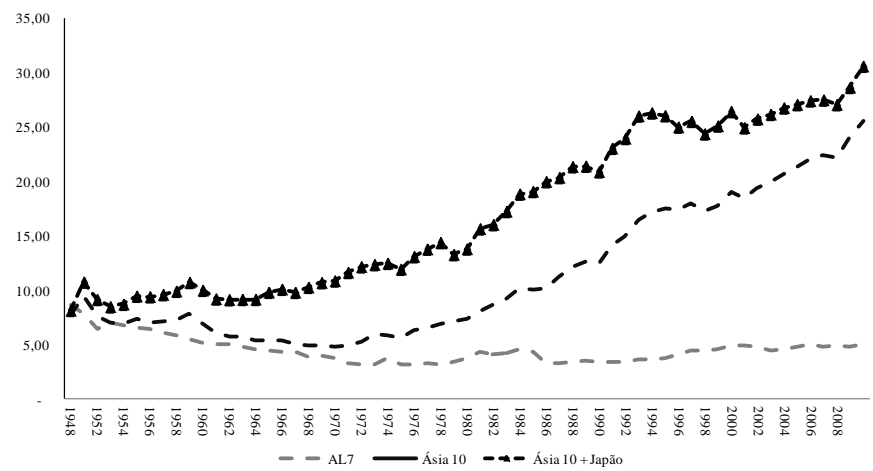

Source of charts: own elaboration based on WTO data <http://stat.wto.org/Home/WSDBHome.aspx?Language=E $>$. Accessed on February 5, 2012. AL7 = Argentina, Brazil, Chile, Colombia, Peru, Venezuela and Mexico. Asia10 = China, Hong Kong, India, Indonesia, South Korea, Malaysia, Philippines, Singapore, Taiwan and Thailand.

Asian growth has been accompanied by deep structural changes (Tables 1 and 2). There was intense urbanization, relative loss of agriculture importance in income generation, and strong increase in the share of foreign trade in GDP. In no other region in the world, the exports of goods and services expanded so fast. The gross capital formation and increase on industry participation in income led the process of productive modernization. While in Latin America the period that followed the debt crisis in the early 1980s was characterized by the loss of dynamism in the industry and decline of investment, the Asian economies managed to maintain and, in some cases, increase the pace of accumulation of capital, under the leadership of the industrial sector. As highlighted by the literature on growth inspired in the tradition from Keynes and Kaldor, these two factors are essential to explain the long-term performance of an economy. In view of Palma $(2007,2011)$ the success of Asia and the framework of semi-stagnation in other peripheral regions, especially in Latin America, show the ability of the former of sustaining a dynamic of expansion based on the accumulation of capital led by the urban-industrial activities. In turn, Rodrik (2006) suggests that there is robust empirical evidence of strong correlation between growth acceleration and the existence of diverse productive structures with a high participation of the manufacturing industry. 
André Cunha, Marcos Lélis, Julimar Bichara, Manuela de Lima

Table 1 - Sector Distribution of GDP in Selected Economies, 1960-2010 * (\%)

\begin{tabular}{|c|c|c|c|c|c|c|c|c|c|}
\hline & \multicolumn{3}{|c|}{ Agriculture } & \multicolumn{3}{|c|}{ Industry } & \multicolumn{3}{|c|}{ Services } \\
\hline & $1960 \mathrm{~s}$ & $1980 \mathrm{~s}$ & 2000 s & $1960 \mathrm{~s}$ & $1980 \mathrm{~s}$ & 2000 s & $1960 \mathrm{~s}$ & $1980 \mathrm{~s}$ & $2000 \mathrm{~s}$ \\
\hline & \multicolumn{9}{|c|}{ I. Latin America } \\
\hline Argentina & 10,3 & 8,3 & 9,1 & 47,0 & 39,4 & 32,9 & 42,7 & 52,3 & 58,0 \\
\hline Brazil & 16,0 & 10,2 & 6,1 & 36,3 & 44,0 & 27,8 & 47,7 & 45,8 & 66,1 \\
\hline Chile & 8,4 & 7,7 & 4,4 & 40,1 & 39,1 & 43,0 & 51,5 & 53,2 & 52,6 \\
\hline Colombia & 27,9 & 18,1 & 8,1 & 27,0 & 35,2 & 32,8 & 45,1 & 46,7 & 59,1 \\
\hline Mexico & 12,3 & 8,9 & 3,8 & 28,7 & 33,5 & 33,0 & 59,0 & 57,7 & 63,1 \\
\hline Peru & 18,8 & 9,7 & 7,5 & 30,3 & 31,6 & 33,8 & 50,8 & 58,8 & 58,6 \\
\hline Venezuela & 5,5 & 5,9 & 4,2 & 39,6 & 49,6 & 53,1 & 54,2 & 44,4 & 42,7 \\
\hline \multicolumn{10}{|c|}{ II. Asia } \\
\hline China & 38,4 & 29,1 & 11,9 & 34,7 & 43,6 & 46,5 & 26,8 & 27,3 & 41,5 \\
\hline Singapore & nd & 0,9 & 0,1 & nd & 36,9 & 30,3 & nd & 62,2 & 69,7 \\
\hline South Korea & 31,0 & 12,7 & 3,3 & 22,3 & 39,7 & 37,2 & 46,8 & 47,6 & 59,5 \\
\hline Philippines & 278 & 23,5 & 12,9 & 31,2 & 36,4 & 33,5 & 41,0 & 40,1 & 53,7 \\
\hline Hong Kong & nd & 0,5 & 0,1 & nd & 28,6 & 9,2 & nd & 71,0 & 90,7 \\
\hline India & 42,5 & 31,3 & 19,4 & 20,3 & 26,2 & 27,3 & 37,2 & 42,5 & 53,3 \\
\hline Indonesia & 50,9 & 22,7 & 14,5 & 14,8 & 37,9 & 46,2 & 34,3 & 39,4 & 39,2 \\
\hline Malaysia & 30,7 & 19,6 & 9,3 & 25,8 & 39,1 & 46,9 & 43,4 & 41,3 & 43,7 \\
\hline Thailand & 31,1 & 16,8 & 10,6 & 22,8 & 32,8 & 43,7 & 46,0 & 50,3 & 45,7 \\
\hline \multicolumn{10}{|c|}{ III. Advanced economies } \\
\hline Germany & 6,4 & 3,2 & 1,0 & 46,0 & 39,9 & 29,2 & 47,6 & 57,0 & 69,8 \\
\hline U.S. & 3,7 & 2,0 & 1,2 & 48,1 & 38,7 & 21,6 & 48,2 & 59,3 & 77,3 \\
\hline Japan & 3,5 & 2,4 & 1,6 & 35,2 & 30,6 & 29,7 & 61,2 & 67,0 & 68,8 \\
\hline
\end{tabular}

Source: World Development Indicators on Line, World Bank < http://data.worldbank.org>. Accessed on February 5 , 2012.

$\left({ }^{*}\right)$ We calculated the averages in each decade. In the 1960 s there were, in some cases, gaps of information. 


\section{Table 2 - International Trade, Investment and Rural Population in Selected Economies, 1960-2010 *}

\begin{tabular}{|c|c|c|c|c|c|c|c|c|c|c|c|c|}
\hline & \multicolumn{3}{|c|}{$\begin{array}{l}\text { Rural Population (\% } \\
\text { of total) }\end{array}$} & \multicolumn{6}{|c|}{$\begin{array}{l}\text { International Trade in Goods and Services (\% of } \\
\text { GDP) }\end{array}$} & \multicolumn{3}{|c|}{$\begin{array}{c}\text { Gross Capital } \\
\text { Formation (\% of GDP) }\end{array}$} \\
\hline & & & & \multicolumn{3}{|c|}{ Imports } & \multicolumn{3}{|c|}{ Exports } & & & \\
\hline & 1960 & 1980 & 2010 & $1960 \mathrm{~s}$ & $1980 \mathrm{~s}$ & $2000 \mathrm{~s}$ & $1960 \mathrm{~s}$ & $1980 \mathrm{~s}$ & $2000 \mathrm{~s}$ & $1960 \mathrm{~s}$ & $1980 \mathrm{~s}$ & $2000 \mathrm{~s}$ \\
\hline \multicolumn{13}{|c|}{ I. Latin America } \\
\hline Argentina & 26,4 & 17,1 & 7,6 & 6,0 & 6,2 & 16,9 & 6,3 & 9,3 & 23,1 & 22,4 & 18,8 & 19,6 \\
\hline Brazil & 55,1 & 32,6 & 13,5 & 6,5 & 7,3 & 12,2 & 6,7 & 10,1 & 13,6 & 19,7 & 20,7 & 17,5 \\
\hline Chile & 32,2 & 18,8 & 11,0 & 13,8 & 26,2 & 32,8 & 13,7 & 27,5 & 40,1 & 18,1 & 18,9 & 21,3 \\
\hline Colombia & 55,0 & 37,9 & 24,9 & 13,2 & 13,6 & 19,2 & 12,5 & 15,0 & 16,7 & 19,3 & 19,4 & 20,5 \\
\hline Mexico & 49,2 & 33,7 & 22,2 & 9,6 & 13,7 & 31,8 & 7,7 & 17,2 & 27,5 & 19,3 & 21,9 & 24,0 \\
\hline Peru & 53,2 & 35,4 & 28,4 & 19,9 & 16,7 & 20,2 & 18,2 & 16,7 & 23,0 & 32,6 & 24,5 & 20,7 \\
\hline Venezuela & 38,4 & 20,8 & 6,0 & 15,9 & 20,7 & 20,0 & 26,3 & 25,5 & 30,8 & 25,3 & 19,8 & 20,8 \\
\hline \multicolumn{13}{|c|}{ II. Asia } \\
\hline China & 84,0 & 80,4 & 55,1 & 2,7 & 14,0 & 27,0 & 2,6 & 13,7 & 31,7 & 20,3 & 36,1 & 42,5 \\
\hline Singapore & 0,0 & 0,0 & 0,0 & nd & nd & 188,1 & nd & nd & 213,2 & 22,7 & 41,6 & 23,1 \\
\hline $\begin{array}{l}\text { South } \\
\text { Korea }\end{array}$ & 72,3 & 43,3 & 18,1 & 19,3 & 32,3 & 40,0 & 8,9 & 33,5 & 42,1 & 20,3 & 31,0 & 29,4 \\
\hline Philippines & 69,7 & 62,5 & 33,6 & 18,5 & 26,7 & 47,0 & 17,9 & 25,1 & 42,8 & 22,2 & 21,7 & 20,5 \\
\hline Hong Kong & 14,8 & 8,5 & 0,0 & 80,5 & 104,0 & 180,3 & 78,5 & 110,8 & 189,2 & 25,4 & 27,0 & 22,1 \\
\hline India & 82,1 & 76,9 & 69,9 & 5,5 & 7,9 & 21,4 & 4,0 & 6,1 & 18,6 & 15,4 & 22,4 & 32,3 \\
\hline Indonesia & 85,4 & 77,9 & 46,3 & 12,5 & 22,8 & 26,2 & 10,3 & 24,5 & 30,8 & 10,4 & 29,2 & 26,0 \\
\hline Malaysia & 73,4 & 58,0 & 27,8 & 37,9 & 56,6 & 87,9 & 41,7 & 59,0 & 108,2 & 17,9 & 28,3 & 21,2 \\
\hline Thailand & 80,3 & 73,2 & 66,0 & 18,4 & 30,0 & 64,7 & 16,2 & 26,9 & 70,3 & 21,5 & 30,7 & 26,2 \\
\hline \multicolumn{13}{|c|}{ III. Advanced economies } \\
\hline Germany & 28,6 & 27,2 & 26,2 & 9,5 & 10,4 & 36,6 & 16,4 & 23,3 & 41,6 & 30,5 & 22,1 & 18,2 \\
\hline U.S. & 30,0 & 26,3 & 17,7 & 17,9 & 24,9 & 15,4 & 5,3 & 8,4 & 10,9 & 19,2 & 19,4 & 15,1 \\
\hline Japan & 56,9 & 40,4 & 33,2 & 4,7 & 10,3 & 12,9 & 9,9 & 12,5 & 14,1 & 35,8 & 30,2 & 23,1 \\
\hline
\end{tabular}

Source: World Development Indicators on Line, World Bank <http://data.worldbank.org>. Accessed on February 5, 2012.

$\left.{ }^{*}\right)$ We calculated the averages in each decade. In the 1960 s there were, in some cases, gaps of information.

The structure of exports, reflecting the deep transformation in the productive base of those economies, passed to be characterized by the 
predominance of manufacturing with greater technological content ${ }^{16}$. The comparison between Asia and Latin America highlights the difficulties of the economies of the latter to maintain denser and more sophisticated productive and trade structures. Starting in the 1980s, Asian countries expanded their internationalization, maintaining high levels of involvement of industry in GDP, while Latin Americans watch an intense deindustrialization. This occurs in a context of reduced levels of gross capital formation in Latin America, for average values under $20 \%$ of GDP, while in Asia the most dynamic economies kept investments close to $30 \%$ of GDP ${ }^{17}$ (Table 2, PALMA, 2007 and 2011).

The most dynamic Asian countries also stand out in an attempt to maintain a pattern of development increasingly rooted in sectors which carry technological innovations that have transformed the production basis and consumption patterns in the last three decades. South Korea, Singapore and Japan are among those who invest the most in research and development $(\mathrm{R} \& D)^{18}$. South Korea deserves special mention, inasmuch as its effort to reach the nations who determine the techno-productive boundaries is translated into R\&D expenditure close to the leading economies in innovative efforts, such as Sweden, Finland, Israel and Japan. And this happened in spite of its per capita income being equivalent to something between $50 \%$ and $60 \%$ of per capita income of the richest nations. China also has been making a breakthrough in this area. Between 1996 and 1998 spending on R\&D were on average $0.6 \%$ of GDP. Between 2006 and 2008, these investments reached 1.4\% of GDP. To

\footnotetext{
16 For the 2005-2009 period, the Asian average of share in ICT products ("Information and Communication Technology", which are goods of information and communications technology, namely, telecommunications, audio, video, computers and related equipment, electronic components, among others, excludes software) is $27 \%$ of total exports, against $11 \%$ for the OECD countries and Latin America, or the $2.4 \%$ recorded in Brazil. See: World Development Indicators on Line, World Bank $<$ http://data.worldbank.org >. Accessed on February 5, 2012.

17 After the financial crisis of 1997 and 1998, there was a decline in investment, especially in ASEAN countries.

${ }_{18}$ Taking the average for the 2006-2008 period, the OECD economies of high income spent, on average, $2.37 \%$ of GDP annually in R\&D, compared to an average of $2.29 \%$ between 1996 and 1998 . Finland, Israel, Japan and Sweden spent about $4 \%$ of their GDP, compared to $3 \%$ of the previous decade. In Latin America such expenditure represented, between 2006 and 2008, only 0.65\% of GDP, Brazil having $1 \%$ of GDP. A decade earlier, these indicators were respectively $0.5 \%$ and $0.7 \%$. Finally, the recent Asian average was $1.37 \%$ of GDP, with highlights to Singapore (2.4\%) and Korea (3.1\%). China spent $1.4 \%$ in 2006-2008 against $0.6 \%$ for 1996-1998. Source: own elaboration based on World Development Indicators on Line, World Bank < http://data.worldbank.org>. Accessed on February 5, 2012.
} 
understand in perspective, the costs from Brazil were, in these two moments, $0.7 \%$ and $1 \%$ of GDP. Despite emerging as a regional leader in $R \& D$, Brazil is still far behind the more dynamic Asian economies. The Asian lead investments in information technology, equipment and software ${ }^{19}$, in physical and human infrastructure to give support to these sectors and in terms of maintaining a favorable business environment for enterprises (Table 3).

It is also important to remember that, in the Asian case, growth was associated with a significant increase in the quality of life in general, expressed in indicators such as increased per capita consumption, access to clean water, schooling, reducing infant mortality, etc. ${ }^{20}$, as well as lower macroeconomic instability ${ }^{21}$.

\footnotetext{
19 The indicator of spending on information technology and communication computes costs for the purchase of computer equipment and software, computing and communication services and other expenses associated with these technologies as a proportion of GDP of each country. For the 2003-2008 period are: Malaysia $(11.9 \%)$, Korea $(9.2 \%)$, Singapore $(8.8 \%)$, Hong Kong $(8 \%)$, China $(7.3 \%)$ and Japan $(6.8 \%)$. The world average is $5.5 \%$ and spending in the U.S. $7.4 \%$, Germany $5.8 \%$ and Brazil $5.7 \%$. The other Latin American economies, as well as other Asian economies have indicators below or near the world average. See: World Development Indicators on Line, World Bank $<$ http://data.worldbank.org $>$. Accessed on February 5, 2012.

${ }^{20}$ We chose to avoid here exhaustive data. The Annual Reports of the World Bank (World Development Indicators, World Development Reports) and UN (UNDP Human Development Reports) show that Asian countries have been presenting, over the last decades, significant improvements in virtually all human development indicators in a higher rate than all the developing countries. Details on World Bank (1993, 2008) and Chang (2006).

${ }^{21}$ The main macroeconomic indicators signal the fact that the more advanced economies of the region, such as Japan, South Korea, Taiwan, Hong Kong and Singapore, have tended to perform more favorably than the relatively less developed countries, such as those that comprise the ASEAN. These, in turn, maintained a behavior closer to that of the Latin American countries (Palma, 2007 and 2010).
} 
Table 3 - Indicators of Technological Infrastructure and Business Environment in Selected Economies, 1985-2011

\begin{tabular}{|c|c|c|c|c|c|c|c|}
\hline & \multicolumn{2}{|c|}{$\begin{array}{l}\text { Articles published in } \\
\text { scientific and } \\
\text { technical journals* }\end{array}$} & $\begin{array}{c}\text { Conventional } \\
\text { telephone } \\
\text { lines (per } 100 \\
\text { inhab.) }\end{array}$ & $\begin{array}{c}\text { Mobile } \\
\text { telephone } \\
\text { lines (per } \\
100 \text { inhab.) }\end{array}$ & $\begin{array}{c}\text { Internet } \\
\text { users } \\
\text { (per } 100 \\
\text { inhab.) }\end{array}$ & $\begin{array}{c}\text { Doing } \\
\text { Bussiness } \\
\text { Index** }\end{array}$ & $\begin{array}{c}\text { Logistics } \\
\text { index } \\
* * * \\
(1=\text { low, } \\
5=\text { high })\end{array}$ \\
\hline & $\begin{array}{l}1985- \\
1989\end{array}$ & $\begin{array}{l}2003- \\
2007\end{array}$ & 2010 & 2010 & 2010 & 2011 & 2009 \\
\hline $\begin{array}{l}\text { I. Latin } \\
\text { America }\end{array}$ & 5.808 & 20683 & 181 & 982 & 34 & $\mathrm{~N} / \mathrm{a}$ & 27 \\
\hline Argentina & 1.413 & 3.117 & 24,7 & 141,8 & 36 & 113 & 3,1 \\
\hline Brazil & 1.778 & 10.097 & 21,6 & 104,1 & 41 & 126 & 3,2 \\
\hline Chile & 659 & 1.560 & 20,2 & 116,0 & 45 & 39 & 3,1 \\
\hline Colombia & 94 & 409 & 14,7 & 93,8 & 37 & 42 & 2,8 \\
\hline Mexico & 894 & 3.936 & 17,5 & 80,6 & 31 & 53 & 3,1 \\
\hline Peru & 59 & 132 & 10,9 & 100,1 & 34 & 41 & 2,8 \\
\hline Venezuela & 53 & 220 & 24,6 & 96,7 & 36 & 177 & 2,7 \\
\hline $\begin{array}{l}\text { Asia } \\
\text { (developing } \\
\text { country) }\end{array}$ & 4.278 & 45.015 & 18,9 & 73,3 & 36 & N/a & 2,7 \\
\hline China & 3.606 & 42.320 & 22,0 & 64,2 & 34 & 91 & 3,5 \\
\hline Singapore & 395 & 3.513 & 39,1 & 143,9 & 70 & 1 & 4,1 \\
\hline $\begin{array}{l}\text { South } \\
\text { Korea }\end{array}$ & 684 & 16.286 & 58,4 & 103,9 & 83 & 8 & 3,6 \\
\hline Philippines & 139 & 180 & 7,3 & 85,7 & 9 & 136 & 3,1 \\
\hline Hong Kong & 423 & N/a & 61,5 & 189,8 & 69 & 2 & 3,9 \\
\hline India & 9.438 & 15.080 & 3,0 & 64,2 & 8 & 132 & 3,1 \\
\hline Indonesia & 71 & 191 & 15,8 & 91,7 & 9 & 129 & 2,8 \\
\hline Malaysia & 207 & 642 & 16,1 & 121,3 & 55 & 18 & 3,4 \\
\hline $\begin{array}{l}\text { Thailand } \\
\text { Advanced } \\
\text { economies }\end{array}$ & 255 & 1.339 & 10,1 & 100,8 & 21 & 17 & 3,3 \\
\hline $\begin{array}{l}\text { (OCDE - } \\
\text { high } \\
\text { income) }\end{array}$ & 386.765 & 573.694 & 45,1 & 105,8 & 77 & $\mathbf{N} / \mathbf{a}$ & 3,7 \\
\hline Germany & 27.875 & 43.674 & 55,8 & 128,0 & 82 & 19 & 4,1 \\
\hline USA & 170.702 & 204.593 & 48,9 & 90,2 & 79 & 4 & 3,9 \\
\hline Japan & 32.700 & 55.323 & 31,7 & 94,7 & 79 & 20 & 4,0 \\
\hline
\end{tabular}

Source: Own elaboration based on World Development Indicators on Line, World Bank <http://data.worldbank.org>. Aaccessed on February 5, 2012.

(*) Papers published in the areas of biology, chemistry, physics, mathematics and related areas.

$\left({ }^{* *}\right)$ In a total of 183 countries, ranked first (1) presents the best business environment, and the final (183), the worst.

$\left({ }^{* *}\right)$ The rate of the perceptual logistic efficiency regards to the administration procedures, infrastructure, and costs. 
The evaluation of the Asian experience leads us to the realization that there is no single model for successful industrialization. If the export orientation, investments in training human capital and state intervention are points in common, historical context and industrial purposes - and, therefore, the utilized instruments - were different. The different objectives of each country, especially in regard to the deepening of industrialization, would have resulted in different positions in face of foreign direct investment (FDI). Singapore, for example, would be more liberal in this respect, having mounted its exporter drive based on transnational corporations. This would have implied a lower local technological effort. On the other hand, Korea and Taiwan would have had the opposite behavior. They encouraged the local technological development, via national companies - large conglomerates in Korea, small and medium enterprises and state-owned enterprises in Taiwan. This restricted the participation of transnational corporations. The experience of Hong Kong would be closer to the behavior envisioned by neoclassical paradigm, with a lower selectivity in policy, given that the deepening of industrialization was not central in its dynamics of modernization. Countries such as Malaysia and Thailand, with greater emphasis, and the Philippines and Indonesia (JOMO, 2001 and 2005) used strategies closer to those found in other laggard economies, particularly in Latin America and Eastern Europe, structuring its production industrial basis with a strong presence of FDI. China, in turn, sought to provide foreign capital and technology through the strategy of establishing partnerships with local companies in order to strengthen their capacities. After three decades of rapid growth, the country is trying to advance in the effort to generate endogenous innovation effort in the midst of an intense process of internationalization of their companies.

It seems reasonable to assume that the Chinese recent success reflects the Asian regional dynamics of expansion. Since the late 1970s, the country has experienced an intense process of modernization of its economy, integration into international flows of trade and investment, which is generating a deep transformation of their own socioeconomic reality as well as the international economic and political order. In recent years, despite the international financial crisis, the resolutions of the Chinese government to reform and opening remain unchanged and in progress. 
With an average growth of income of $10 \%$ per year, between 1979 and 2010 , the Chinese economy has become the second largest in the world ${ }^{22}$. The latest data from the $\mathrm{IMF}^{23}$, which refers to the year 2010, show that with a population of 1,341 million, the per capita income of China is still relatively modest: US\$ 4,382 in current dollars, occupying the $93^{\text {th }}$ position in the IMF ranking of 179 countries with available data, or 7.519 per capita in international dollars (purchasing power parity), which meant the $94^{\text {th }}$ position. To put that in perspective, in terms of current values the GDP per capita of China amounted to $9.3 \%$ of U.S. GDP per capita, while at purchasing power parity this proportion was $15.9 \%$. In terms of HDI (human development index) ${ }^{24}$, China has an average level of development, appearing in the $89^{\text {th }}$ position among 169 countries.

In 2010, China consolidated its position as global leader in exports of goods, being the second largest importer in the world. Between 1980 and 2010 exports grew, on average, $16 \%$ per year, while world exports advanced by $7 \%$ a year. Because of this, Chinese participation in the world total rose from just over $1 \%$ in the early $1980 \mathrm{~s}$ - a level equivalent to the Brazilian - to more than $10 \%$ in 2010 . International comparisons of the conditions of competitiveness of economies suggest that China still does not occupy a prominent position, despite important recent advances ${ }^{25,26}$.

The last five-year plans, especially the $12^{\text {th }}$ Five-Year Plan for Economic and Social Development (CASEY; KOLESKI, 2011), which covers the period from 2011 to 2015, highlight the concern of Chinese leaders and strategists to renew its development model. Increased emphasis on the domestic

\footnotetext{
${ }^{22}$ China exported US $\$ 1,578$ billion or $10.4 \%$ of the world, the U.S. exported US\$1,278 (8.4\%), Germany exported US\$ 1,269 (8.3\%) and Japan exported $\$ 770$ billion (5.1\%). From the perpective of imports these countries imported, respectively: US\$ 1,395 billion (9.1\% of world total), US\$ 1,968 billion $(10.4 \%)$, US\$ 1,067 billion $(6.9 \%)$, US\$ 693 billion (4.5\%). Source: WTO.

${ }_{23}^{23}$ World Economic Outlook Database, 2011. $<$ http://www.imf.org/external/pubs/ft/weo/2011/01/weodata/index.aspx>.

${ }^{24}$ See: <http://hdrstats.undp.org/en/countries/profiles/CHN.html>. Accessed on May, 2011. In 2010 its HDI was 0,663 . In 1980 it was 0,368 .

25 See "The Global Competitiveness 2010-2011": $<$ http://www3.weforum.org/docs/WEF_GlobalCompetitivenessReport_2010-11.pdf >. Accessed in May, 2011 and <http://www.doingbusiness.org/rankings >. Accessed in May, 2011.

26 See "Doing $2011 ", \quad$ Business of World <http://www.doingbusiness.org/data/exploreeconomies/china $>$. Accessed in May, 2011.
} 
market and, therefore, the necessary redistribution of income and reduction of propensity to save of households through increases in public investment on social safety net, and environmental and energy sustainability are essential vectors for the managing future. Furthermore, in addition to "world factory", China aspires to be a source of technological innovation and generation of new patterns of production in consumption. Thus, the challenge is to move from the "Made in China" step to the "Designed and Made in China" stage (CASEY; KOLESKI, 2011; NOLAN, 2011; WONG, 2011). In both cases, the internationalization of its economy seems to be essential.

However, as in the previous plans, there is a potential contradiction between the desired pace of change and the need for job creation and income expansion. The latter acts as social stabilizers and legitimations of the political status quo. So, even if China migrates to a less unbalanced development path, it does not seem credible that this takes place in the near future. More of the same is what you can expect in the short term, that is, utilization of the export drive - in a world where advanced economies are in crisis and the peripheral economies try to keep their dynamism - and heavy doses of gross capital formation $^{27}$.

Therefore, despite the effort to "grow based on the internal market", China will follow in seeking to advance in international markets, especially in regions with greater potential for absorption of its products, as in Latin America and Africa. As highlighted by ECLAC-CEPAL (2011a. 2011b), China is the regional hub for exports. Because of this, the Asian giant has a trade deficit

\footnotetext{
${ }_{27}$ About Chinese imbalances and the need to create jobs "at any cost", Zhang and Liu (2010) comment that: "The lack of domestic consumption as well as heavy dependence on investments and net exports is a consequence of previous or existing economic and social policies. For example, the increase income disparity and lack of social security networks have depressed aggregate consumption propensity, thus impairing overall domestic demand. At the same time, the inefficient banking system, lower environmental standards and an immature capital market have made the cost of using capital unnaturally low, thus providing distorted investment incentives." (p. 9). "Heavy investment and lack of consumption caused overcapacity in China's production, particularly manufacturing production. In order to find markets for the overcapacity of Chinese industries, the Chinese government had to support enterprises to sell their products in international markets by keeping Chinese currency lower than its market value" (p.9). "The considerations of labor absorption are an important reason why China's police makers have hesitated to reduce the dependence on investments and exports, as well as to tackle environmental degradation." (p. 11)
} 
with its more developed neighbors, especially Japan, South Korea and Taiwan, suppliers of technology-intensive manufacturing, and developing neighbors, such as the ASEAN countries, recently benefited from the free trade agreement and that supply China with natural resources - and therefore are competing, in different segments, with the economies of Latin America and Africa that are in the same range of supply, without benefiting from the terms of that agreement.

\section{Industry and International Trade in a Sino-centric World: regressive specialization of Brazil?}

The previous section provided evidence that the more successful peripheral economies in terms of growth and economic modernization sustained their trajectories based on high volumes of investment and maintenance of diversified production structures, reflected in the growing technological sophistication of its production and exports. Starting in the $1930 \mathrm{~s}$, and with more intensity between 1950s and 1980s, Brazil also experienced an intense process of structural change centered on the binomial urbanization and industrialization. During that period, the goal was to overcome the primary-exports model, whose intrinsic vulnerabilities became all too evident in the interwar years. The specialization in the production and export of products with low elasticities, price and income, and import of manufactured goods with high income elasticity, led to structural problems of balance of payments. Such economies were characterized by the duality of the modern sectors, linked to exporter complexes, but dependent on international demand, and traditional sectors, with low productivity levels and linked to domestic demand.

In Brazil, as in other peripheral nations, particularly those characterized by large populations and areas, this stage was characterized by, among other things, the low absorption of labor surplus, fragile tax bases and dependent on international trade, and poor physical (roads, ports, energy production and distribution, communications, etc.) and social (education, health etc.) infrastructure. The concentration of income, wealth and political power in social classes possessing the ownership of natural resources (mines, farms, etc.) tended to be reflected in political and social institutions, unable to produce spontaneously robust growth trajectories. 
At the height of its modernization process in 1980, Brazil had the largest manufacturing sector of developing countries and ranked in the eighth place overall, with $2.6 \%$ of internationally added value. In that year China was in twelfth place with $1.7 \%$ and South Korea in the twenty-seventh, with $0.6 \%$ of world production of manufactures. In 2010, Brazil appeared in eleventh place, behind China, South Korea, India and Mexico ${ }^{28}$. However, despite its relative decline, Brazil still accounts for $1.7 \%$ of global production. In this context, authors such as Palma (2007 and 2011) and Bresser-Pereira (2010) suggest that Latin American economies suffer from a dynamic of early deindustrialization, visible when controlling this trend for the levels of per capita income. Excessive dependence of intensive sectors on natural resource and the lack of development policies, in stark contrast to the Asian experience, are pointed out as plausible explanations for the poor performance of countries in the region.

This perception is reinforced by the literature that studies the impacts of specialization in production and export of natural resources over the longterm performance of economies ${ }^{29}$. Sachs and Warner $(1995 ; 1997)$ find there is a negative relationship between long-term growth and participation in natural resource intensive exports as a proportion of income. These influential works reinforced the debate on the existence of a "natural resource curse" ${ }^{30}$. The pessimism associated with this type of approach is explicit in the so-called "Dutch disease", which is a manifestation of the pernicious effect of the appreciation of national currency in face of the foreign exchange inflow boom originated in commodity exports ${ }^{31}$. In this context, the change in relative prices

${ }^{28}$ See: United Nations Statistics Division - National Accounts; Palma (2007, 2011).

${ }^{29}$ For an exhaustive review see, among others, Sinnott, Nash and De La Torre (2010), Prebisch (1984), Reinert (2007), Rodrik (2006 and 2010), Palma (2007 and 2011).

${ }^{30}$ The subsequent empirical literature has pointed to methodological shortcomings and possible problems of endogeneity in the econometric exercises. That is, there are difficulties of needing to what extent countries cannot grow because they rely heavily on natural resources or otherwise, if this dependence is originally from low growth. The existence of developed countries with this type of specialization would indicate the possibility that the abundance of natural resources would not be necessarily a determinant of low growth. Thus, for much of the literature, it is the institutions, not nature, that determine the trajectories of development (World Bank, 2008, Sinnott, Nash and De La Torre, 2010, Ledernan and Maloney, 2010).

${ }^{31}$ The General Secretary of UNCTAD, Supachai Panitchpakdi, believes that the strong capital inflows may cause effects similar to the Dutch disease: "Today's experience of capital flows and currency 
between tradable and non-tradable goods tends to discourage the diversification of the productive structure and foreign trade ${ }^{32}$.

Furthermore, the old developmental literature and its contemporary heirs (FURTADO, 2003; PREBISCH, 1984; KRUGMAN, 1993; RODRIK, 2006;2010; REINERT, 2007) pointed to the limits of intensive sectors in natural resource to multiply income, employment and taxes through the nucleating of more complex and intensive in technology productive chains. Assuming as valid the Prebisch-Singer hypothesis of the secular trend to falling terms of trade, the countries exporting natural resources would suffer, with repeatedly negative shocks in terms of trade (the ratio between prices of exports and imports) and, therefore, structural difficulties in balance of payments. Moreover, lower income elasticity of primary products vis-à-vis the manufacturers limit the relative expansion of commodity markets. The low elasticity in supply and demand of these goods is to be transmitted to prices, potentially more volatile, undermining the macroeconomic management of countries whose income, in general, and the revenues of the public sector, in particular, are strongly dependent on some sectors. Rent-seeking, corruption and serious concentration of income, non-democratic political regimes, wars, political instability and low-quality institutions would be recurrences in countries that are highly dependent on the production and export of commodities (DE LA TORRE, 2010).

The non-renewable character of certain commodities, especially oil and minerals, can generate processes of over-exploitation of resources and negative externalities such as pollution, depletion of other associated resources (water, air, soil, etc.). In addition to the disincentives created by the "Dutch disease", the character of physical enclave of the production, as well as the fact that the

misalignment has much in common with the 'Dutch disease' experience of some commodity exporting countries in the past." (Statements by Supachai Panitchpakdi, Secretary-General of UNCTAD, International Monetary and Financial Committee of the IMF, Washington DC, 16 April 2011 $<$ http://www.unctad.org/Templates/webflyer.asp?docid=14856\&intItemID=3549\&lang=1 $>$. Accessed on May, 2011.

${ }^{32}$ This would be a serious problem inasmuch as, both for old developmentalists, and for the growth of modern literature there would be a strong correlation between growth acceleration and the existence of diverse and productive structures with a high share of manufacturing industry. See Rodrik (2006 and 2010 ). 
initial investment to obtain them are very high and long maturation return, may lead to conflicts of ownership, reduced investment in other sectors of the economy, concentration of physical and legal infrastructure to sustain exclusively such activities, etc. The excessive concentration of investments in commodity-producing sectors could result, also, in reduction of investment in human resources and capital-intensive sectors reducing, in the long term, the overall capital stock savings.

It is from these findings and the literature and evidence outlined in section 2 that we analyze the recent performance of the Brazilian economy. The recent recovery of dynamism occurred in the context where China's rise fueled demand for natural resources and thereby contributed to a beneficial cycle in terms of trade. Economies with abundant natural resources have experienced faster growth and improved macroeconomic - particularly in relation to external and fiscal solvency - and social conditions. Brazil fits this case. However, this relatively better performance did not reverse the negative picture inherited by a quarter-century of slow growth. In particular, echoing the literature previously discussed, the processing industry continues to grow little and aggregate investment and productivity in the Brazilian economy remain comparatively low. And, more importantly, in this moment of shy resumption, the global financial crisis broke out that, among other challenges, has produced an environment of greater competition in manufacturing. Apparently China leads the process of occupation of all possible spaces, given the need to maintain its active exporting complex responsible for generating over 120 million jobs (ZAHNG; LIU, 2010:11).

In this context, we should observe the behavior of trade and production in the Brazilian economy. In a first approximation, the third chart provides the balance of international trade in goods from Brazil in the 1996-2011 period. It was surprising to overcome the deficits inherited from the period of monetary stability, particularly since 2002, when world demand was strong and exporters benefited from favorable exchange rates. Since then, the country has been producing trade surpluses averaging US $\$ 30$ billion per year. However, as can be seen in panel $A$, the manufacturing industry has lost the ability to generate surpluses. On the contrary, since 2008 the deficits pile up. The external environment after the crisis, with lower growth and more competition, especially from Chinese and Asian production, associated with the expansion of 
domestic demand and the appreciation of national currency, have induced the increase in import coefficients and the fall in industry export coefficients (CUNHA; LÉLIS; FLIGENSPAN, 2011).

\section{Chart 3 - Trade Balance of Brazil, 1996-2011 (US\$ million)}

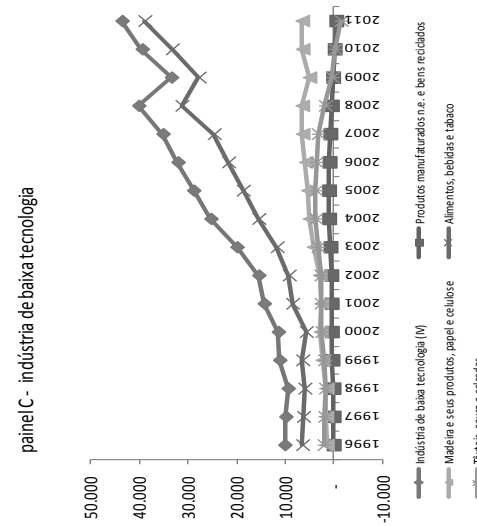

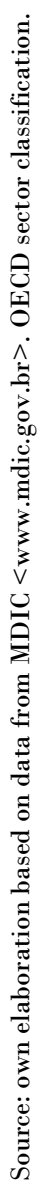


Looking at the sectors according to technological intensity, it appears that, except for the low-tech industry, all others were strongly deficient in the recent period (Figure 2, panel C). And, among the sectors classified as low-tech, only the export of food, beverages and tobacco, especially, and wood, wood products, paper and cellulose, in the background, produce surplus. Segments of intensive labor and that traditionally had trade surpluses, such as textiles, leather and footwear, have become unprofitable.

Chart 4 reinforces the perception that there is a process of specialization and concentration of an export basket. The $\mathrm{HH}^{33}$ indicator shows high and increasing concentration of the agenda for Africa, Asia and China, moderate concentration for exports to Europe and Latin America, and low concentration only with the U.S.

\section{Chart 4 - Concentration of Brazilian Exports, 1995-2010 (Herfindhal-Hirschman)}

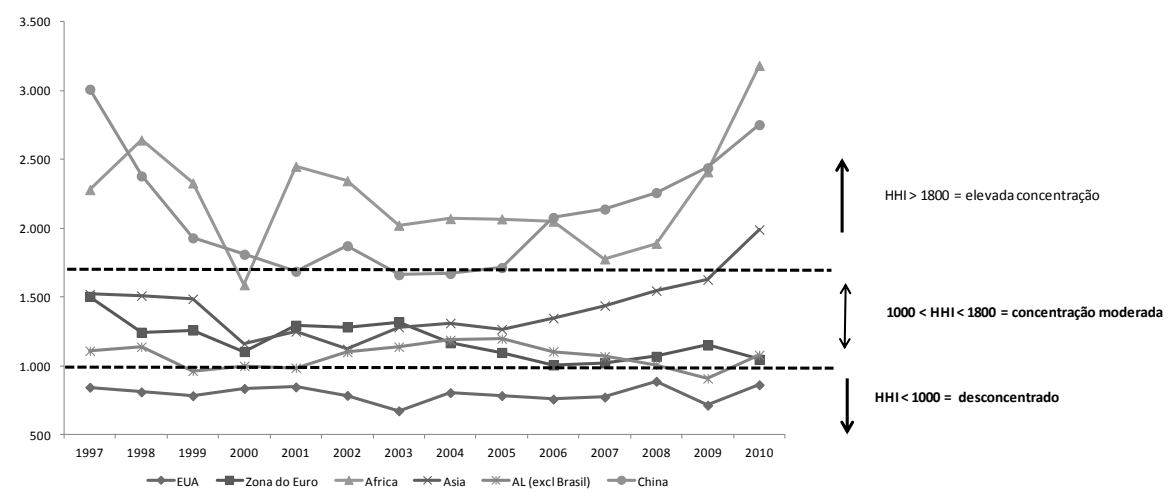

Primary source of data: Global Trade Information Services (GTIS).

${ }^{33}$ The concentration index of exports sector (Herfindahl-Hirschman Index, HHI), obeys the following definition: $H H I_{j}=\sum_{k=1}^{n}\left(\frac{x_{j, k}}{X_{j, w}} \times 100\right)^{2}$ Where: $x_{j, k}=$ Exports from the "k" sector performed by the " $\mathrm{j} "$ country; $X_{j, w}=$ Total exports originating in the " $\mathrm{j}$ " country. This indicator has a range where a result less than 1,000 indicates a low concentration, a HHI between 1,000 and 1,800 characterized moderate concentration and, finally, a value of greater than 1,800 HHI indicates a situation where the export basket is concentrated in few sectors. 
It should be noted that China experiences, reproducing to some extent the successful pattern of its more developed neighbors, a dynamic of deepening and diversifying their production and international trade structures. Between 1995 and 2010, the rising power has succeeded in diversifying its export markets $^{34}$ and products ${ }^{35}$ which, moreover, reveal growing technological sophistication. The sectors that produce and export more sophisticated products, intensive in scale and technology, advanced from $29 \%$ to $62 \%$ of total exports $^{36}$. Remember that during this period Chinese exports grew tenfold in value from US $\$ 151$ billion to US\$1,578 billion.

Considering the relevance of intra-regional trade to Brazil and evidences of the international literature (GREENWAY; MAHABIR; MILNER, 2008; GIOVANNETTI; SANFILIPPO, 2009; WOOD; MAYER, 2010) is important to consider whether China is replacing Brazil in Latin American market of manufactured products. According to Lélis, Cunha and Santos (2012) the answer is probably yes. They found that between 1994 and 2008, particularly in the post-2003, both Chinese and Brazilian manufacturing exports in the region had great growth. Latin America economic recovery after 2002 opened up space for such expansion. However, Chinese exports grew 40 times more than the Brazilian ones did. Naturally, Chinese exports were much lower than the Brazilian ones a few years ago; now, this is no longer true. Since 2007, the export of Chinese manufactured products has been growing faster than exports of Brazilian manufactured goods. Lélis, Cunha and Santos (2012) showed that Chinese exports to Latin America are less concentrated than the Brazilian exports to the region ${ }^{37}$, while Chinese exports corresponded to imports from Latin America more than the Brazilian exports. In 1996, the rate of additional

\footnotetext{
${ }^{34}$ Take as reference the index of concentration ratio (CR), characterizing which portion of the " $n$ " regions has in total exported by the Chinese economy. In 1995, the 15 major trading partners of China, excluding Hong Kong absorbed $60.6 \%$ of its exports. In 2010, they accounted for $56.7 \%$. (Own calculations based on raw data from the Global Trade Information Services).

35 The Chinese HH concentration index shows low concentration (or high deconcentration) of the Chinese staff in all target markets. However, the post-2008 marks a slight movement of concentration in mature markets and devolution in other regions. Still, it appears that the $\mathrm{HH}$ is less than 1000 , in 2010 , to all regions (own calculations based on raw data from Global Trade Information Services).

${ }^{36}$ Own calculations based on raw data from the Global Trade Information Services.

37 Concentration index of exports (Herfindhal-Hirschman) of Brazilian exports fluctuated around 1000 , between 1996 and 2008, and reached 1007 in 2008, while the same index for Chinese exports rose from 895 in 1996 to 685 in 2008 (Lélis, Cunha and Santos, 2012).
} 
trade $^{38}$ of Chinese exports to Latin America (excluding Brazil) was 47.6, while in 2008 it grew to 58.9. In the same period, the rate of additional trade of Brazilian exports was, respectively, 56.9 and 50.8. To the authors Chinese exports have replaced the Brazilians in the region due to its volume-effect and diversification.

Despite its uniqueness, the Brazilian experience echoes the already voluminous literature that seeks to assess the impacts of China's rise in Latin America. Lederman, Olarreaga, and Perry (2008), Jenkins (2010), ECLACCEPAL (2011a, 2011b), Phillips (2011), Leão, Pinto and Acioly (2011), Jenkins and Barbosa (2012), among others, provide an updated review of arguments, where there is a clear divide between optimists and pessimists. In the first field, in the Chinese demand for natural resources is identified a source of dynamism for the region's economies, and in the imports of finished products and equipment is found the potential for increased well-being and competitiveness of local producers. Moreover, the establishment of partnerships with Chinese companies and foreign direct investment originated in the Asian giant would contribute, respectively, so that Latin American companies could expand their internationalization as constituent parts of global production networks, and to finance the balance of payments and infrastructure works. In another field, even if assuming the potential benefit from Chinese demand, the pessimists emphasize the risks associated with excessive specialization in production and exports of natural-resource-intensive products, amid a process of renewed deindustrialization impetus, particularly in the more diversified economies. Assuming that there are different effects between rich economies and exporters of natural resources, especially in South America, and economies linked to the U.S. market and exporter of labor-intensive manufactures, such as Mexico and Central America and the Caribbean, it appears that the displacement of manufactured exports, the diversion of FDI from the region to China and the return to a dependent and reflex situation would refer to a framework of

\footnotetext{
${ }^{38}$ ICTY = 100 - sum (| mik - xij | / 2), where: (i) xij is the participation of good " $\mathrm{i}$ " in total exports of the country "j"; and (ii) "mik" is the participation of good "i" in the total imports of country k. When the index is zero, no good is exported by the country or imported by another. When the index is 100 , the quantities imported and exported match (Hoekman, Mattoo and English, 2002, Appendix B). HOEKMAN, B. M.; MATTOO, A. and ENGLISH, P. Development, Trade, and the WTO: A Handbook Washington DC: The World Bank, 2002.
} 
regressive specialization, equivalent to that criticized by the political economy from ECLAC-CEPAL (PREBISCH, 1984; FURTADO, 2003) ${ }^{39}$.

In these frameworks, the Brazilian situation suggests the occurrence of the two effects, namely, the stimulus to sectors that benefit from Chinese demand for natural resources and competitive pressures in the industry, as illustrated earlier (see Chart 3). While the manufacturing industry had an increase in its external deficit between 2008 and 2011, the primary sector obtained significant surpluses. Even if the evidence presented in this session does not support that such behavior is due to commercial links between Brazil and China, one cannot ignore this possibility. The international literature has pointed to evidence in this direction, where the competition with Chinese exports displaces their rivals from the main markets and exacerbate the loss of dynamism in industrial production (GREENWAY; MAHABIR; MILNER, 2008; GIOVANNETTI; SANFILIPPO, 2009; WOOD; MAYER, 2010; JENKINS; BARBOSA, 2012; LÉLIS; CUNHA; SANTOS, 2012).

From the standpoint of international trade, while China has moved from a participation equivalent to the Brazilian in exports of goods in the early $1980 \mathrm{~s}$, about $1.5 \%$ of world total, to more than $10 \%$ after 2010 , Brazil dropped to less than $1 \%$ in 1990 , resuming that level only at the end of the first decade of the $21^{\text {st }}$ century. In a broader perspective, Latin America's share has fluctuated around $7 \%$ in the last four decades, a period of strong Asian ascension (see section 2). This situation worsens inasmuch as the export basket returned its focus on primary products for the whole region. In 2010, 54\% of regional exports were of primary products, as seen in Chart 5 .

\footnotetext{
${ }^{39}$ For an update of concepts and their application to the Brazilian case see, among others, Coutinho (1997) and Jayme Jr. and Rezende (2009).
} 
Chart 5 - Structure of Exports in Latin America, 1970-2010 (\%)

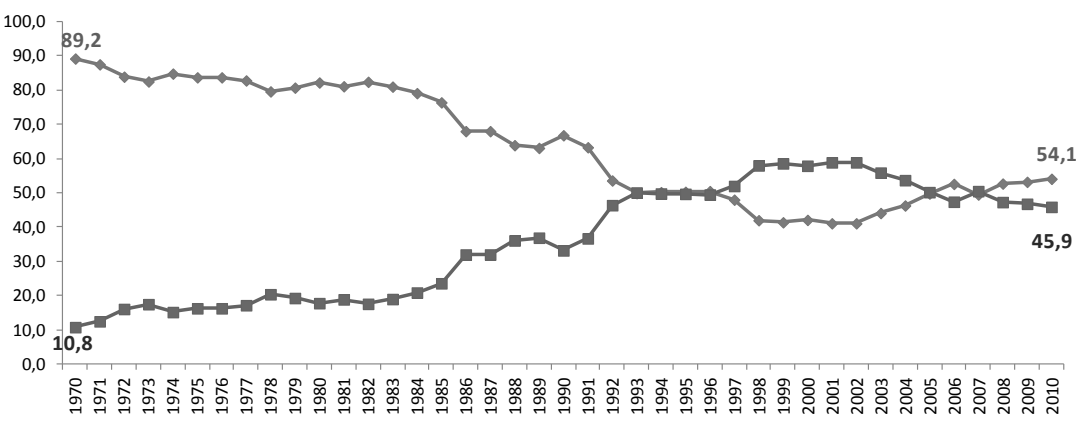

Source: ECLAC's Statistical Yearbook 2011.

The trade with East Asian countries is particularly intensive in natural resource exports (Chart 6). Countries like Brazil and Mexico have had in regional markets, in the U.S. and middle-income countries, the main destinations for exports of manufactures. It is precisely in these markets that Chinese competition has intensified, particularly in the post-global financial crisis (CUNHA ET AL., 2011; LÉLIS; CUNHA; SANTOS, 2012).

Chart 6 - Structure of Exports in Latin America by Major Destinations, 20082010 (average \%)

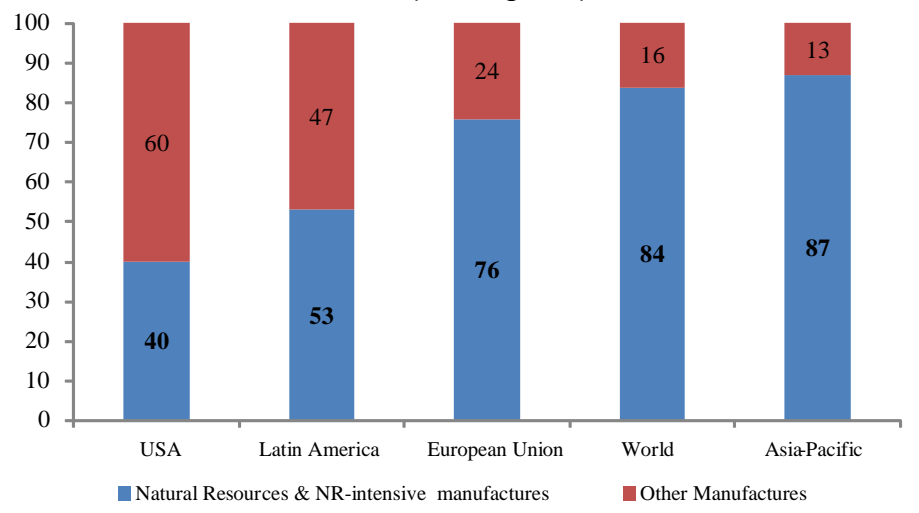

Source: ECLAC-CEPAL (2011b) 
It is true that this more general framework needs to be detailed, inasmuch as various regional economies are structurally dependent on the production and export of commodities, being the case of Argentina, Chile, Colombia and Venezuela, among others (Chart 7, panel A). In turn, Mexico and Brazil (Chart 7, panel B), which were able to, throughout their industrialization efforts, diversify their production and export structures, experienced in the recent cycle of high commodity prices, partly due to Chinese demand, an increasing trend in the relative share of natural resource-intensive products. According to ECLAC-CEPAL (2011a, 2011b), in both sets of economies, one can see, as a result of greater trade ties with China and the impacts of the Chinese rise on the global economy, a specialization in a few products, usually nonprocessed natural resources (table 4 ).

\section{Chart 7 - Exports of Primary Products in Selected Economies, 1970-2010 (\% of total exports)}
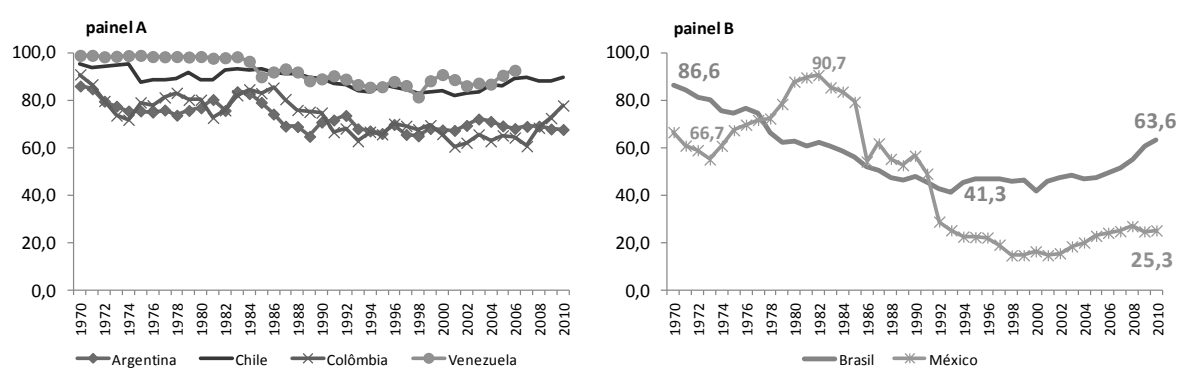

Souce: CEPAL - ECLAC's Statistical Yearbook 2011.

Thus, Table 4 reinforces the perception of deterioration in the quality of bilateral trade, in which China starts to buy products featuring the lowest possible degree of processing and to export increasingly sophisticated manufacturing, reproducing the classical picture of North-South trade criticized by Prebisch (1984) and Furtado (2003). 
Table 4 - Structure of Bilateral Trade between Latin America (excl. Mexico) and China, 1990-2008 (\%)

\begin{tabular}{|c|c|c|c|c|}
\hline & \multicolumn{2}{|c|}{ Exports } & \multicolumn{2}{|c|}{ Imports } \\
\hline & 1990 & 2008 & 1990 & 2008 \\
\hline Primary Products & 29,2 & 72,1 & 42,8 & 2,4 \\
\hline $\begin{array}{l}\text { Manufactures Products Intensive in } \\
\text { Natural Resources and Labor }\end{array}$ & 17,5 & 6,8 & 25,2 & 22,9 \\
\hline Other Manufactures & 53,3 & 21,0 & 31,9 & 74,7 \\
\hline Total & 100,0 & 100,0 & 100,0 & 100,0 \\
\hline
\end{tabular}

Source: ECLAC-CEPAL - Overview of the international insertion of Latin America and the Caribbean 2008-2009.

Finally, closer trade ties have produced a new phenomenon in Brazil and other Latin American economies: their business cycles are increasingly tied to the Chinese cycle. Cunha et al. (2011) show that the cycles in Brazil are increasingly correlated with China and Argentina, and less related to the United States. This synchronization can be explained by trade and is associated with a pattern of business that Brazil tends to specialize in the production and export of natural resources. Calderon (2008) ${ }^{40}$ found similar results when studying cyclical convergence between the countries of Latin America, India and China. In turn, Cesa-Bianchi et al. (2011) showed that due to the channels of commerce the long-term impact of a shock of China's GDP over the Latin American economies have tripled since the mid-1990s, while the long-term impacts of a shock of U.S. GDP decreased by half. The Inter-American Development Bank (IDB) also considers that the pace of adjustment of the Chinese economy will bring non-negligible impacts to Latin America. By transiting from an aggregate level of investment of $46 \%$ to $48 \%$ of GDP to a standard between $30 \%$ and $35 \%$ of GDP, the rebalancing of the Chinese standard of growth will affect commodity prices and, therefore, the performance of countries that are producers and exporters of natural resources (IADB, 2012). The IDB simulates

${ }^{40}$ Op. cit. 
several scenarios in which the pace of slowdown in Chinese growth produces contraction effects in the region, with different levels of depth ${ }^{41}$.

Finally, we must consider that Chinese growth has entered a new stage: after becoming a major destination for foreign direct investment in the 1990s and $2000 \mathrm{~s}$, China has become an important exporter of capital in the form of FDI, particularly after 2005. Energy and diverse natural resources industries have been prioritized, as well as countries that are characterized by the relative abundance of those products and that are located in Asia, Africa, Latin America and the Middle East.

Based on data from official sources and independent researchers (SALIDJANOVA, 2011; ECLACL-CEPAL, 2011a; 2011b), it is possible to assume that the accumulated volume of foreign investments originated in China exceed US\$ 200 billion between 2005 and 2010. While the overall volume of FDI lost dynamism after 2008, Chinese investment accelerated, signaling the fact that the global financial crisis has opened the prospect of acquiring strategic assets. To evaluate the type of geographic targeting of Chinese investments, chart 8 reports the regional intensity index (RII), ${ }^{42}$ calculated in analogy to the traditional indicators of trade intensity. An index greater than 1 indicates that the region receives more investments with higher relative intensity, that is, it is more important for the Chinese economy than for the combined economies of the world. Through this indicator, the Chinese investment is between two and three times more intense in Latin America, Africa and the Middle East than that verified in all the economies in the world. Indicators were calculated considering two clusters: China and China + Hong Kong.

\footnotetext{
${ }^{41}$ In summary: "A second risk to global economic prospects is growth in the Chinese economy. For many years, rapid credit growth has fueled China's high investment rate, which will surely decline over the medium term; the question is whether this will be with growth falling mildly or a swifter deceleration. Given China's increased importance in global trade, a faster deceleration in China would affect world growth, thereby impacting Latin America and the Caribbean. Moreover, given the high commodity intensity of the economy, Chinese growth is important for maintaining relatively high commodity prices." (IADB, 2012, p. 7).

${ }_{42}$ IIR = Rij/Riw. Where: Rij represents the participation on "I" region in total investments originated in the "country j"; RIW is the participation of the same region in global investments.
} 


\section{Chart 8 - Index of Regional Intensity of Chinese Investment, 2005-2011 *}

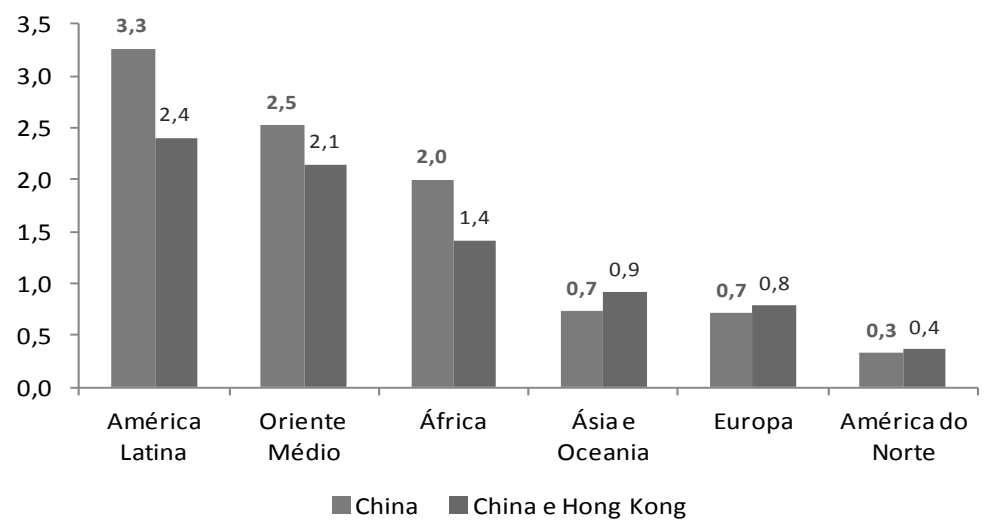

Source of raw data: FDI Markets. Note: $(*)$ until June.

For the case of Latin America, ECLAC-CEPAL (2011a, 2011b) indicates cumulative investments of US\$ 7.3 billion in the 1990-2000 period, US\$ 15.2 billion in 2010 and US\$ 22.7 billion for the post-2011 period. As important as the amount involved is realizing its expansive dynamic. After the 2008 crisis, China seeks to transform its financial state and corporate powers in terms of the acquisition of strategic assets, especially if providers of future access to the supply of natural resources or markets.

\section{Final remarks}

This paper began with a brief review of the discussion on the determinants of the different performances of the peripheral economies over the past decades, period during which the Asian countries, in successive waves, increased their participation in the most dynamic market circuits of the global economy. At the same time, the main Latin American countries, despite the recent improvement in performance, showed a loss of participation in product, industrial production and international trade. The external debt crisis in the 1980s questioned the development model led by State, which led to a reversal of paradigm towards the liberalizing adjustment of the $1990 \mathrm{~s}$ and $2000 \mathrm{~s}$. During this period, the advance of the techno-productive and the subsequent demand for more sophisticated technological, human and institutional inputs made more difficult 
the efforts of Latin American countries to reverse the low growth of investment, productivity and income.

The acceleration of growth and improvement in macroeconomic conditions only came after 2003, largely as a response to increased demand and, thus, prices of commodities, benefiting the countries that produce and export natural resources. This dynamic has been determined, among other things, by the strong growth in emerging economies, especially China. In one generation, about one third of humanity has been incorporated into global processes of production and trade. Hundreds of millions of Asian farmers migrated from the countryside to the cities in a massive, deep and fast process of urbanization and industrialization ${ }^{43}$. The impact on international prices of raw materials was felt in the post-2002 high cycle, while manufacturing and services from China, India and their neighbors helped to maintain stable or decreasing prices. Consequently, natural resource-exporting countries and importers of industrial products experienced a favorable shock in terms of trade, with positive effects on external accounts and, in some cases, on public accounts (IADB, 2012; ECLAC-CEPAL, 2011a, 2011b).

In this context, the literature about the impacts of China's rise has emphasized that the increase in demand for natural resources would ensure an export-led growth dynamic in peripheral regions in which those abound. Moreover, China has become an important source of capital, through investment of its companies, financing from official banks and other forms of resource transfer. The high competitiveness of its manufacturing would contribute to the increase in the welfare of the importing countries, both by consumers hungry for cheaper consumer goods and companies requiring capital goods, industrial inputs and, potentially, participation in global production networks focused on China.

In a less optimistic view, other studies point out that the specialization in production and export of natural resources is usually associated with low levels of long-term growth, concentration of income, wealth and power, weak and poorly democratic institutions, and corruption, among other problems.

${ }^{43}$ To put that in perspective, China is urbanizing at a rate of $1 \%$ of the population, which now amounts to 13 million people, to put it in perspective, two cities of Rio de Janeiro. 
Furthermore, they stress that the strengthening of the manufacturing industry is at the explanatory center of sustained processes of growth and inducers of virtuous changes in productive structures and in their respective societies. Thus, the industry would be the bearer of enhancing properties of expansion in income and production efficiency. In contrast, deindustrialization, especially when it occurs early, in countries that have not yet reached the highest levels of income per capita, would largely explain the loss in dynamism of the middle-income economies of the capitalist periphery, especially in Latin America.

The evidence presented here suggests that China's rise, for the case of Latin America, in general, and Brazil in particular, introduces a vector of risk and opportunity that tends to be biased for the first dimension. The opportunities opened up by the production and export of natural resources and attraction of investments associated with these production complexes has been important in the recovery. However, there is not, yet, strong evidence of a structural reversal in the trend of deterioration in the terms of trade, or lower volatility in commodity prices. Even smaller evidence that price and income elasticities of natural resources -intensive products have changed, to avoid the problems noted by Thirlwall and Prebisch (JAYME JR.; REZENDE, 2009), that is, the possibility of structural imbalances in balance of payment insofar as the the growth of domestic and international income produces a greater increase in imports (manufacturing) than exports (commodities). Likewise, exceptions are still countries that were able to avoid the problems associated with the socalled "natural resource curse".

With increasingly intense trade channels between China and Latin America, the countries in the region have become more sensitive to cyclical movements in the economy of the former. The global financial crisis, by causing a reduction in income growth in mature economies, led policy makers and Chinese companies to seek to further diversify their exports. The impressive growth of China in recent decades has been focused on investment and exports. Despite intentions to reorient the model, toward a greater importance of domestic demand, this adjustment will not occur in a stable way in a short period of time. The need to maintain jobs, growth at relatively high levels and, consequently, an environment of social and political stability is the central concern of the Chinese political leadership. These elements and the evidence presented here and in the related literature suggest that, after 2008, the Chinese 
presence in Latin American markets and other peripheral regions has intensified, displacing Brazilian exports, especially manufacturing, which may be contributing to the density loss in industrial production.

If, in the political and strategic field, experts point to the possibility that Brazil and China consolidate a South-South partnership that is able to, in the context of a reordering of the international system, strengthen the position of the peripheral nations (HART, 2010; ALTEMANI DE OLIVEIRA, 2010; HAIBIN, 2010; VISENTINI, 2011), in the economic field, which is not isolated from the others nor will cease to affect domestic and foreign policies of both countries, there seems to be a crystallizing relationship of the North-South type. In the Brazilian perspective, without a coherent and robust development strategy, it will be difficult to avoid a regressive process of specialization and over-exploitation of natural resources, with the potential compromise of the main assets of the country: its wide range of biodiversity and natural resources, the size of its domestic market as a basis for expansion of domestic production, and a relative political and institutional stability. More severely, the incipient economic and social recovery of the country may be aborted.

Following the reasoning of Castro (CASTRO;CASTRO, 2011), Brazil needs to reinvent its development strategy, advancing on the countercyclical policies adopted after 2008. Thus, the State has a decisive role, and its policies should enhance the positive dimension of stimuli originated in the new international order and, where possible, try to neutralize the risks of its negative side. In this sense, it is important (i) to reorient macroeconomic policies to maintain income and employment growth; (ii) to control the exchange rate and capital flows to reduce the impacts of external turbulence; (iii) to effectively manage resources from exports of natural resources, particularly with the country's new status as a producer of oil, to minimize the effects of "Dutch disease" and ensure the financing of public investments; (iv) to improve the distribution of income, invest in human capital and reduce social differences; (v) to implement robust and sustainable development policies to reduce infrastructure bottlenecks, increase the competitiveness of local industry, increase levels of investment and, especially, preserve the environment and biodiversity of the country. 
This article aims to contribute to the ongoing debate, insofar as it is far from clear that the net result of the greater Sino-Brazilian interaction will be positive for the country ${ }^{44}$, particularly when one realizes the lack of a development strategy that addresses the deep transformations derived from China's rise.

\section{REFERENCES}

ALTEMANI DE OLIVEIRA, H. Brasil e China: uma nova aliança não escrita? Revista Brasileira de Política Internacional, v. 53 (edição especial), p. 88-106, 2010.

ANGANG HU. China and the World: Assessment and Prospect of the "Post-Crisis" Era. TMD Working Paper Series, No. 040, Department of International Development. University of Oxford, 2010.

BABONES, S. The Middling Kingdom - The hype and the reality of China's rise. Foreign Affairs, September/October, Vol. 90, N. 5, p. 79-88, 2011.

BRESLIN, S. 'The China Model' and the Global Crisis. International Affairs, Volume 87, Number 6, November, p. 1323-1343, November, 2011.

BRESSER-PEREIRA, L. C. (Editor). Doença holandesa e indústria. Rio de Janeiro: Editora FGV, 2010.

CALDERÓN, C. Trade, specialization, and cycle synchronization: explaining output comovement between Latin America, China, and India. In. LEDERMAN, D., OLARREAGA, M. e PERRY, G. (Ed.), China 's and India`s challenge to Latin America. Washington, DC: The World Bank, 2008.

\footnotetext{
${ }^{44}$ For Rubens Barbosa: "Our dynamic relations with China are bringing opportunities and challenges that must be answered not with improvised but in a strategic medium and long term. Exports of agricultural products and minerals will continue to grow. And the gradual replacement of industrial products for Brazilian products imported from China may increase the decreasing participation of industry in our gross domestic product (GDP). The trend of concentration of exports in few commodities and deindustrialization - if, in the short term, are not faced with effective policies - may reduce Brazil to the category of simple commodity producer and our industry, the domestic market". See: <http://www.itamaraty.gov.br/sala-de-imprensa/selecao-diaria-de-noticias/midias-nacionais/brasil/oestado-de-sao-paulo/2011/11/22/os-desafios-da-asia-para-o-brasil-artigo-rubens/print-nota $>$, accessed on March 25, 2012. In the same line, Sergio Amaral argues that: "The challenge of China, so isn't only the peculiarity and the shape of its investments or increasing volume of imported products at a price substantially lower than the national equivalent. You are in coping, both the company and the government, a reality that is new, different and presents itself as two sides of the same coin: a promising, another unsettling. This reality can't be treated as business as usual". See: <http://www.itamaraty.gov.br/sala-de-imprensa/artigos-relevantes/o-desafio-da-china-o-estado-de-s.paulo-23-01-2011, accessed on March 25, 2012.
} 
CanUTO, O.; GIUGale, M. (Editors). The Day After Tomorrow: a handbook on the future of economic policy in the developing world. Washington, DC: The World Bank, 2010.

CASEY, J., KOLESKI, K. Backgrounder: China's 12th Five-Year Plan. U.S.-China Economic \& Security Review Commission, June 24, 2011 (http://www.uscc.gov/researchpapers/2011/12th-FiveYearPlan_062811.pdf, Access: October 01, 2011).

Castro, A. C., CASTro, L. B. (organizadoras). Antonio Barros de Castro: o inconformista - homenagem do Ipea ao Mestre. Brasília: Ipea, 2011.

CEPAL. La República Popular China y América Latina y el Caribe. Hacia una nueva fase en el vínculo económico y comercial, Junio. Santiago de Chile: Comisión Económica para América Latina, 2011a. Available at http://eclac.org.cl (accessed in October 2011)

CEPAL. Panorama de la inserción internacional de la América Latina y el Caribe 20102011. Septiembre. Santiago de Chile: Comisión Económica para América Latina, 2011b. Disponível em http://eclac.org.cl (accessed in October 2011)

CERVO, A. L. Brazil's Rise on the International Scene: Brazil and the World. Revista Brasileira Política Internacional, 53 (special edition), p. 7-32, 2010

CESA-BIANCHI, A.; PESARAN, M. H., REBUCCI, A. XU, T. China's Emergence in the World Economy and Business Cycles in Latin America. IDB WORKING PAPER SERIES No. IDB-WP-266, September. Inter-American Development Bank, 2011.

CLARK, I. China and the United States: a succession of hegemonies? International Affairs, Vol. 87, N. 1, January, p. 13-28, 2011.

COUTINHO, L. A especialização regressiva: um balanço do desempenho industrial pósestabilização. In VELLOSO, J.P.R. (org.) Brasil: desafios de um país em transformação. Editora José Olympio, 1997.

CRANDALL, R. The Post-American Hemisphere. Power and Politics in an Autonomous Latin America. Foreign Affairs, May/June, Volume 90, Number 3, p. 83-95, 2011.

CUNHA, A. M., BICHARA, J. S., MONSUETO, S. E., LÉLIS, M. T. C. . Impactos da Ascensão da China Sobre a Economia Brasileira: comércio e convergência cíclica. Revista de Economia Contemporânea, v. 15, p. 406-440, 2011.

CUNHA, A. M., LÉLIS, M. T. C. , FLIGENSPAN, F. B.. Comércio exterior e indústria manufatureira no Brasil: velhas questões e novas evidências para o período 2000 a 2010. In: FUNAG (Org.). III Seminário sobre Pesquisas em Relações Econômicas Internacionais. Brasília: FUNAG, 2011.

DEVLIN, R., ESTEVADEORDAL, A., RODRIGUEZ, A (Editors). The Emergence of China: opportunities and challenges for the Latin America and Caribbean. Washington, DC: Inter-American Development Bank and Harvard University, 2006.

FENBY, J. China's Domestic Economy. In: SHAMBAUGH. D. Charting China's Future: domestic and international challenges. Routledge, 2011. 
FUNAKUSHI, T.; LOSER, C. China's Rising Economic Presence in Latin America. Inter-American Dialogue, June 2005.

FURTADO, C. Raízes do subdesenvolvimento. Rio de Janeiro: Civilização Brasileira, 2003.

GIOVANNETTI, G., SANFILIPPO, M. Do Chinese Exports Crowd-out African Goods? An Econometric Analysis by Country and Sector. European Journal of Development Research, v. 21, N. 4, p. 506-530, 2009.

GIOVANNETTI, G., SANFILIPPO, M., VELUCCHI M. The “China effect" on EU Exports to OECD markets - A focus on Italy. Working Paper n. 17, December. Universita' degli Studi di Firenze, 2011 (http://www.dse.unifi.it/upload/sub/WP17 2011.pdf. Access on March 13, 2012.)

GOLDMAN SACHS. BRICs and Beyond. The Goldman Sachs Group/Global Economics Department, $2007 . \quad$ (http://www2.goldmansachs.com/ourthinking/brics/index.html, October 2011)

GREENAWAY, D., MAHABIR, A., MILNER, C. Has China displaced other Asian countries' exports? China Economic Review, Volume 19, Issue 2, June, Pages 152-169, 2008.

HAIBIN, N. Emerging Global Partnership: Brazil and China. Revista Brasileira de Política Internacional, v. 53 (edição especial), p. 183-192, 2010.

HALPER, S. The Beijing Consensus: how China's authoritarian model will dominate the twenty-first century. New York, Basic Books, 2010.

HOEKMAN, B. M.; MATTOO, A. e ENGLISH, P. Development, Trade, and the WTO: A Handbook (World Bank Trade and Development Series). Apêndices B e C. Washington DC: The World Bank, 2002.

IADB. The World of Forking Paths: Latin America and the Caribbean facing global economic risks. Washington, DC: Inter American Development Bank, 2012.

IEDI. A indústria de transformação por intensidade tecnológica: o desafio de crescer sem deteriorar ainda mais o saldo comercial. Carta IEDI, São Paulo, IEDI, n. 454, 11 de fevereiro de 2011.

IEDI. O Comércio Exterior Brasileiro em 2011. Análise IEDI, 20/01/2012.

IKENBERRY, G. J. The Future of the Liberal World Order: internationalism after America. Foreign Affairs, May/June, Vol. 90, N. 3, p. 56-68, 2011.

INTERNATIONAL MONETARY FUND - IMF. People's Republic of China - IMF Country Report No. 10/238, July. Washington, 2010.

INTERNATIONAL MONETARY FUND - IMF. World Economic Outlook, September. Washington, $\quad$ DC, 2011. (http:/www.imf.org/external/pubs/ft/weo/2011/02/index.htm, accessed in October 2011).

JAYME JR, F. G., REZENDE, M. F. C. Crescimento Econômico e Restrição Externa: Teoria e a Experiência Brasileira. In: Renault, Michel; Leonardo Mello. (Org.). Crescimento Econômico: Setor Externo e Inflação. 1 ed. Brasília: IPEA, 2009.

JENKINS, R. China's Global Expansion and Latin America. Journal of Latin American Studies, Vol. 42, Part 4, November, 809-837, 2010. 
JENKINS, R., BARBOSA, A. F. Fear for Manufacturing? China and the Future of Industry in Brazil and Latin America. The China Quarterly, 209 , pp 59-81, 2012.

KANG, D. C. China Rising: peace, power and order in East Asia. Columbia University Press, 2007.

KISSINGER, H. On China. Penguin Press HC, 2011.

KRUGMAN, P. The Rise and Fall of Development Economics, 1993 (http://web.mit.edu/krugman/www/dishpan.html, accessed in September 2010)

KURLANTZICK, J. Charm Offensive: how China's soft power is transforming the World. New Republic Book, 2007.

LEÃO, R. P. F.; PINTO, E. C.; ACIOLY, L. (Editors). A China na Nova Configuração Global - Impactos Políticos e Econômicos. Brasília: IPEA, 2011.

LEDERMAN, D., OLARREAGA, M., PERRY, G. (Ed.). China `s and India 's challenge to Latin American. Washington, DC: World Bank, 2008.

LÉLIS, M. T., CUNHA, A.M., SANTOS, C. El desempeño de las exportaciones de China y el Brasil hacia América Latina, 1994-2009. Revista de la Cepal, N. 106, Abril, p. $57-77,2012$.

MEARSHEImER, J. J. China's Unpeaceful Rise. Current History, Vol. 105, No. 690, April, pp. 160-162, 2006. (accessed in September 2011 http://mearsheimer.uchicago.edu/all-pubs.html)

MORRISON, W. M.; LABONTE, M. China's Holdings of U.S. Securities: Implications for the U.S. Economy. September 26, Congressional Research Service, 2011.

NATIONAL INTELLIGENCE COUNCIL. Global Trends 2025: a transformed world. Washington, DC: National Intelligence Council, 2008.

NAUGHTON, B. The Chinese Economy: transitions and growth. Cambridge, MA: The MIT Press, 2007.

NOLAN, P. China and the Global Economy. In: SHAMBAUGH. D. Charting China's Future: domestic and international challenges. Routledge, 2011.

NYE, Jr, J. S. N. The Future of American Power: dominance and decline in perspective. Foreign Affairs, November/December, Vol. 89, N. 6, p. 2-12, 2010.

PALMA, G. Four Sources of 'De-industrialisation and a New Concept of the 'Dutch Disease'. HSRC EGDI Roundtable, May, 2007.

PALMA, G. Why has productivity growth stagnated in most Latin American countries since the neo-liberal reforms? Cambridge Working Papers in Economics (CWPE) 1030, July, 2011. Available at http://www.econ.cam.ac.uk/dae/repec/cam/pdf/cwpel030.pdf. Accessed on 09/01/2011.

PHILlIPS, N. Re-Ordering the Region? China, Latin America and the Western Hemisphere. European Review of Latin American and European Studies, Number 90, April, p. 89-99, 2011.

PREBISCH, R. Five Stages in My Thinking on Development. In MEIER, Gerald M, SEERS, Dudley (Edit.). Pioneers in Development. Oxford: Oxford University Press, 1984. 
REINERT, E. How Rich Countries Got Rich and Why Poor Countries Stay Poor. Public Affairs, 2007.

RODRIK, D. Industrial Development: Stylized Facts and Policies, 2006 (In United Nations, Industrial Development for the 21st Century, U.N., New York, 2007).

RODRIK, D. The Return of Industrial Policy, April, 2010. (http://www.projectsyndicate.org/commentary/rodrik42/English, accessed in September 2010)

ROWTHORN, R. E.; WELLS, J. R. De-industrialization and foreign trade. Cambridge: Cambridge University Press, 1987

SACHS, J. D.M WARNER, A. Economic Reform and the Process of Global

Integration. Brookings Papers on Economic Activity, v.1, p. 1-95. Washington,

DC: Boorkings Institution, 1995.

SACHS, J.; WARNER, A. Natural Resource Abundance and Economic Growth. Center for International Development and Harvard Institute for International Development. Cambridge MA: Harvard University, 1997.

SALIDJANOVA, N. Going Out: an Overview of China's Outward Foreign Direct Investment, March. U.S.-China Economic and Security Review Commission Research Archive, 2011 . (http:/www.uscc.gov/researchpapers/research_archive.php, accessed in October 2011).

SHIRK, S. L. China: Fragile Superpower: How China's Internal Politics Could Derail Its Peaceful Rise. Oxford University Press, 2007.

SINNOT, E., NASH, J., DE LA TORRE, A. Natural Resources in Latin America and the Caribbean - Beyond Booms and Busts? Washington, DC: The World Bank, 2010.

SUBRAMANIAN, A. The Inevitable Superpower: Why China's Dominance is a Sure Thing. Foreign Affairs, September/October, Vol., N. 5, p. 66-78, 2011.

TIMMER, H., DAILAMI, M., IRVING, J., HAUSWALD, R., MASSON, P. Global Development Horizons 2011. Multipolarity: The New Global Economy. Washington, DC: The World Bank, 2012.

TREGENNA, F. Characterising Deindustrialisation: an analysis of changes in manufacturing employment and output internationally. Cambridge Journal of Economics, Vol. 33, Number 3, 433-466, 2009.

UNCTAD. World Investment Report 2011. Geneva: United Nations Conference on Trade and Development, 2011.

VISENTINI, P. G. F. A Novíssima China e o Sistema Internacional. Revista de Sociologia e Política, v. 19, n. suplementar, p. 131-141, nov. 2011.

WONG, R. B. Chinese Political Economy and the International Economy: linking global, regional and domestic possibilities. In: CALHOUN, C.; DERLUGUIAN, G. (Editors). Aftermath - A New Global Economic Order? New York University Press, 2011.

WONG, R. B. Chinese Political Economy and the International Economy: linking global, regional and domestic possibilities. In: CALHOUN, C.; DERLUGUiAn, G. (Editors). Aftermath - A New Global Economic Order? New York University Press, 2011. 
WOOD, A., MAYER, J. Has China De-industrialized other Developing Countries? QEH Working Papers Series Number 175, June, 2010.

WU JIGLIAN. Understanding and Interpreting Chinese Economic Reform. Mason: Thomson, 2005.

YUFAN HAO, C. X., WEI, G., DITTMER, L. (Editors). Challenges to Chinese Foreign Policy: Diplomacy, Globalization and the Next World Power. The University Press ff Kentucky, 2009.

ZHENG BIJIAN. China's Peaceful Rise: Speeches of Zheng Bijian 1997-2004. The Brookings Institution, 2005. (http://www.brookings.edu/events/2005/0616china.aspx, accessed in September 2011). 


\begin{abstract}
This paper assesses how China's rise as a global power has affected Latin America, in general, and Brazil, in particular. If the global economy will increasingly be Asian-centered and Sino-centered in the decades to come, we must ask which role will be reserved for Latin American countries. We argue that, despite the intentions of a reorientation in its growth model, the response of the Chinese policymakers to the international financial crisis has reinforced, at least in the short and medium terms, the dependence on exports and investments. Considering the sluggish recovery in advanced economies, that strategy is likely to amplify Chinese pressures to access dynamic domestic markets in emerging countries. In this context, Latin America represents not only a source of natural resources but an increasingly important market for absorbing the Chinese manufactured products. As a consequence, countries such as Brazil, with more diversified production and international trade structures, might experience a regressive pattern of specialization, which might trigger protectionist reactions and other tensions on bilateral relations with China.
\end{abstract}

\title{
Key Words
}

Brazil; China; Development Strategies.

*Translated by Gabriela Perin 


\title{
THE IMPACT OF THE INTERNATIONAL CRISIS ON BRAZIL'S TRADE WITH THE OTHER BRICS (RUSSIA, INDIA, CHINA AND SOUTH AFRICA)*
}

\author{
André Luiz Reis da Silva** \\ Luiza Peruffo***
}

\section{INTRODUCTION}

The global economy is going through significant change. An important part of this transformation involves the rise of dynamic emerging countries such as Brazil, China, India, Russia and South Africa. Indeed, one could argue that it was precisely the recognition of the economic relevance of these countries that resulted in the creation of the term BRIC - which with the entry of South Africa officially added an ' $\mathrm{S}$ ' to the group's name. ${ }^{1}$ Specifically, Jim O'Neill, in

\footnotetext{
*This article was produced under the Contract for the Provision of Services No. 05-04-2010, UFRGS Process 230780035951093 . We appreciate the assistance of student researchers: Germano Ribeiro Fernandes da Silva, Josuá Gihad Alves Soares, Raquel Tebaldi, Alexandre Piffero Spohr and Luiza Bulhões Olmedo for the data collection and bibliographic search. We also thank the researchers André Moreira Cunha and Ricardo Dathein for their comments and suggestions as well as the undergraduate student researcher Isadora Loreto da Silveira for the English translation and revision. The opinions are the sole responsibility of the authors.

** PhD in Political Science (UFRGS). Professor of International Relations, Department of Economics and International Relations, UFRGS. Researcher at the Brazilian Center of Strategy and International Relations (NERINT/UFRGS). Contact: reisdasilva@hotmail.com.

*** Master's candidate in Development Economics and Bachelor's degree in International Relations at the Universidade Federal do Rio Grande do Sul. Contact: luizaperuffo@yahoo.com.br.

'Source: Declaração de Sanya, available at: http://www.itamaraty.gov.br/temas-mais-informacoes/saibamais-bric/documentos-emitidos-pelos-chefes-de-estado-e-de/sanya-declaration-iii-brics-summit/ Last access: 27 December 2011.
} 
his article entitled Building Better Global Economic BRICs (2001), drew attention to four emerging economies that, according to scenario projections, would show accelerated growth in the following decade. In practice, more than a term to refer to 'developing countries', the BRICS have become a category of analysis, being considered candidates to play a role of growing importance in the international arena. (BAUMANN et al, 2010; O'NEILL, 2001).

Considering the most recent international scenario, it appears that the international crisis initiated in 2008 has been contributing to further accentuate the position of emerging economies, to the extent that, in general, these countries have experienced lighter real and financial impacts than the advanced economies, recovering their previous growth paths with relative brevity. As a result, the G-8 lost its reputation to the G-20, which led the coordination project for international policies, bringing countries like Brazil, Argentina and Mexico to the negotiation table at which decisions are made to define the future of the international system. Therefore, a new scenario is being consolidated in the international economy - the "new normal" -, in which less dynamic industrialized economies and more dynamic emerging ones suggest a new international division of economic and political power (EL-ERIAN, 2008; GROSS, 2009; SPENCE, 2009; CANUTO;GIUGALE, 2010).

Having these recent changes in the international arena as a backdrop, this paper aims to explore the interfaces between the political and economic process of emergence of the BRICS and the dynamics of trade in goods in the period following the global financial crisis. Our main hypothesis is that the prolongation of the crisis effects in the central economies tends to accelerate the previous trend of empowerment of emerging countries, which is expressed also in the international trade. The text is divided into four sections. Following this introduction, the second section presents an overview on the general characteristics of the economies of these four trade partners in analysis, especially in regard to the consequences of the international crisis in each of them. The subsequent section aims to summarize the peculiarities of bilateral trade relations and to analyze trade flows in the period 2000-2011 as well. Finally, some concluding remarks are made. 


\section{BRICS: CHARACTERIZATION AND DEVELOPMENT IN A RECENT INTERNATIONAL CRISIS SCENARIO}

Aside from the fact that they represent economies with potential and growing role in the international system, Brazil, Russia, India, China and South Africa have several individual peculiarities. The purpose of this section is to elucidate some important aspects in this regard, both in terms of size of these economies and of their dynamism, particularly in the context of the international crisis.

Firstly, it is worth noting the demographic weight of the BRICS, as Brazil, Russia, India and China are among the ten most populous countries in the world. Besides, each India's and China's populations are estimated at over one billion people. At the same time, the geographical dimension of the BRICS is also remarkable, since the same four countries are among the ten largest in the world (see Table 1).

Table 1. General Data

\begin{tabular}{|l|l|l|l|l|}
\hline \multirow{2}{*}{ Countries } & \multicolumn{2}{|c|}{ Population } & \multicolumn{2}{c|}{ Area } \\
\cline { 2 - 5 } & $\begin{array}{l}\text { People } \\
\text { (million) }\end{array}$ & $\begin{array}{l}\text { World } \\
\text { Ranking }\end{array}$ & $\mathbf{k m}^{\mathbf{2}}$ (million) & $\begin{array}{l}\text { World } \\
\text { Ranking }\end{array}$ \\
\hline Brazil & 203 & $5^{\text {th }}$ & 8.5 & $5^{\text {th }}$ \\
Russia & 138.7 & $9^{\text {th }}$ & 17.1 & $1^{\text {st }}$ \\
India & 1,189 & $2^{\text {nd }}$ & 3.3 & $7^{\text {th }}$ \\
China & 1,336 & $1^{\text {st }}$ & 9.6 & $4^{\text {th }}$ \\
South & 49 & $25^{\text {th }}$ & 1.2 & $25^{\text {th }}$ \\
Africa & & & & \\
\hline
\end{tabular}

Source: The CIA World Factbook. July 2011 population estimates

Considering the Human Development Index (HDI), from the five countries under analysis, two are classified as high development countries and three as medium development ones. According to the Human Development Report published in 2011 by the United Nations, Russia is, among the BRICS, the country in the highest position in the ranking: $66^{\text {th }}$ (HDI of 0.755). Coming in second, Brazil is in the $84^{\text {th }}$ position $(0.718)$, one position higher than the previous year. Classified as medium human development countries are China (101 st place, HDI of 0.687 ), South Africa (123rd place, HDI of 0.619 ) and India (134 $4^{\text {th }}$ place, HDI of 0.547 ). It is worth mentioning that, from 2006 to 2011 , China climbed six positions in the ranking, Brazil went up three, India, one, and, on the other hand, Russia and South Africa dropped one. 
Since 2001, when the term was created, the evolution of the role of the BRICS in both international economy and political arena is remarkable. Indeed, over the past decade, Brazil, Russia, India and China have contributed with more than a third of the world's GDP growth and today they account for almost one quarter of world's economy, compared to a sixth in 2001 (in terms of Purchasing Power Parity - PPP). In addition, according to projections by Goldman Sachs (2010), the BRIC group (without South Africa) will exceed the U.S. economy in $2018 .^{2}$

According to WTO and IMF data ${ }^{3}$, China's GDP at PPP in 2010 was estimated at over USD 10 trillion (5.9 trillion in current dollars), ranking as the world's third largest economy, only behind the European Union and the United States. China's real GDP grew $11 \%$ on average per year from 2005 to 2010 , growing by $9 \%$ in 2009. In turn, India emerged as the world's fifth largest economy in 2010, with its GDP at PPP estimated at USD 4.2 trillion (1.7 trillion in current dollars). The Indian economy also underwent exceptional growth, at a $9 \%$ rate, in the $2005-2010$ period, growing at such rate even in 2009. Russia ranks as the world's seventh largest economy, with its 2010 GDP at PPP estimated at USD 2.8 trillion (1.5 trillion in current dollars). Unlike Chinese and Indian performances, the average growth rate of Russian economy was only $3 \%$ between 2005 and 2010 , falling $8 \%$ in 2009 , but resuming its growth in 2010 (at 4\%). Brazil ranked in the ninth position, having its 2010 GDP at PPP estimated at USD 2.2 trillion (2 trillion in current dollars). Similarly to Russia, Brazil grew on average 4\% annually between 2005 and 2010, with a 1\% drop in 2009 and a 7\% growth in 2010. Finally, South Africa, which appears as the world's $26^{\text {th }}$ largest economy, has a GDP at PPP estimated at USD 524 billion (363 billion in current dollars). Between 2005 and 2010, South Africa has grown at a $3 \%$ average rate per year. Growth fell $2 \%$ in 2009 , but showed positive growth again in 2010 , of $3 \%$.

2 Available at: http://www2.goldmansachs.com/our-thinking/brics/brics-decade.html. Last access: January 2012.

${ }^{3}$ GDP data obtained at Trade Profiles $O M C$, updated in October 2011. Available at: http://stat.wto.org/CountryProfile/WSDBCountryPFHome.aspx?Language=E. GDP ranking is from CIA World Factbook, 2011, available at: https:/www.cia.gov/library/publications/the-worldfactbook/geos/ch.html. Last access: January 2012. 


\section{André Luiz Reis da Silva, Luiza Peruffo}

In international merchandise trade, in 2010, the BRICS accounted for $16.3 \%$ of the world's exports and $14.6 \%$ of the world's imports, according to the WTO. ${ }^{4}$ Namely, excluding intra-EU trade, China was the world's second largest exporter - accounting for $10.4 \%$ of exports - and the third largest importer accounting for $9.1 \%$ of world imports. ${ }^{5}$ Among the BRICS, Russia ranks in the second place, being the seventh exporting country $(2.6 \%$ of world exports) and the $12^{\text {th }}$ largest exporter $(1.6 \%)$. In the third position comes India, which in 2010 was the $14^{\text {th }}$ largest exporter $(1.4 \%$ of world exports) and the eighth largest importer $(2.1 \%)$. Brazil is in fourth place, as the $16^{\text {th }}$ largest exporter $(1.3 \%)$ and the $14^{\text {th }}$ importer $(1.2 \%)$ in 2010 . Finally, South Africa, whose participation in international trade is much lower than that of the other countries of the group, occupied the $25^{\text {th }}$ position in the ranking of exporting countries $(0.5 \%)$ and the $22^{\text {nd }}$ between the importing countries $(0.6 \%)$.

In 2009, China surpassed Germany as the world's biggest exporter and, in 2010 , overtook Japan as the second largest economy. ${ }^{6}$ In fact, since the late 1970s, China has been experiencing an intense process of modernization of its economy, as well as of integration to international flows of trade and investment, which has been generating a profound transformation of its socioeconomic reality with equally important reflections in the political and economic international order. In 1978, 82\% of the population lived in rural areas, $40 \%$ of production and $70 \%$ of employment were originated in the primary sector. However, in 2009, this scenario was reversed. In addition to a $39 \%$ population growth in this period, $44 \%$ were then living in the city. In this new scenario, typically urban economic activities began to account for most of

\footnotetext{
${ }^{4}$ Trade Profiles WTO, updated in October 2011. Available at: http://stat.wto.org/CountryProfile/WSDBCountryPFHome.aspx?Language=E. Last access: January 2012 .

5 Ranks in world trade of merchandise are defined referring to the EU (27) as one trader (i.e. excluding individual EU (27) members). If we consider European Union (EU (27)) members as individual traders, China was in the first place in the ranking of world exporters and in the second in the ranking of world importers in 2010.

${ }^{6}$ The first world's largest economies ranking aforementioned considers the EU as a bloc, placing China in third.
} 
the production - industry for $49 \%$ and services for $40 \%$ - and employment industry for $27 \%$ and services for $33 \% .^{7}$

Still, according to the World Bank, China is considered an upper middle-income country, with a per capita income estimated at USD 4,260, lower than world's average. It is worth noting that China has the second largest number of poor consumers in the world, only behind India, so that the reduction of poverty in the country remains a key challenge. ${ }^{8}$

Amidst the international financial crisis, China has reduced its growth rate, especially due to lower foreign demand for Chinese products. Notwithstanding, strong fiscal incentive and credit expansion contributed to counteract the effects of the crisis by ensuring a growth between $9 \%$ and $10 \%$ after 2008, below the average performance of $12 \%$ per year in the 2003-2007 period. For 2011, the International Monetary Fund (IMF) forecasts that China's real GDP will grow $9.6 \%$ and will remain at an average rate of $9.5 \%$ over the next five years. ${ }^{9}$

However, China has been facing inflationary pressures - in part as a reflection of its current account surplus - as well as problems with the local government debt, which increased due to stimulus policy. ${ }^{10}$ Thus, among the measures to combat inflation, the Chinese government continues to make policy changes, including the liberalization of Yuan exchange regulations, to encourage Chinese investors and companies to invest abroad. ${ }^{11}$

\footnotetext{
${ }^{7}$ Data presented here has been obtained at the National Bureau of Statistics of China, at its "China Statistical Yearbook 2007" (http://www.stats.gov.cn/tjsj/ndsj/2007/indexeh.htm, collected in February 2009), at the "The Key Indicators for Asia and the Pacific 2010" (http://www.adb.org/Documents/Books/Key_Indicators/2010/Country.asp, last access in November 2010), in Naughton (2007), Wu Jiglian (2005), and at the World Bank database (http://data.worldbank.org/country/china, last access in November 2010).

${ }^{8}$ WORLD BANK. China Overview, 2011, available at: http://www.worldbank.org/en/country/china/overview and World Development Indicators 2010, special China table, available at: http://data.worldbank.org/country/china. Last access: December 2011.

${ }^{9}$ MORRINSON, Wayne M. Congressional Research Service - China's Economic Conditions, 2011. Available at: http://www.fas.org/sgp/crs/row/RL33534.pdf. Last access: December 2011.

${ }^{10} \mathrm{CIA}$ World Factbook, 2011. Available at: https:/www.cia.gov/library/publications/the-worldfactbook/geos/ch.html Last access: December 2011.

${ }^{11}$ WHITE AND WILLIAMS, China's Economy in 2011, 2011. Available at: http://www.whiteandwilliams.com/resources-alerts-9.html. Last access: December 2011.
} 


\section{André Luiz Reis da Silva, Luiza Peruffo}

Similarly to China, India has also undergone significant transformations, being no longer a closed economy and integrating the international scenario since the economic reforms in the country in 1991. Currently, the Indian economy is characterized by liberal trade and foreign investment policies and by a prominent role in the private sector and by deregulation as well.

During the last decade, India has witnessed rapid economic growth, emerging as the fifth largest economy in terms of purchasing power parity. ${ }^{12}$ It is noteworthy that, despite high GDP growth rates in the period before the eruption of the crisis in 2008, the Indian economy had been slowing down since 2006, partly due to the Reserve Bank of India (RBI) priority of reducing inflation. Nonetheless, since September 2008, the RBI has radically changed its main concern in order to ensure the country's economic growth. In accordance with Nassif (2010), the fact that India responded with fiscal and monetary policies in a more rapid and intense manner than Brazil did, for example, was decisive for the economy to not only avoid a recession, but also reestablish a growth trajectory - estimated at over 9\% of real GDP in 2009. In this sense, unlike Brazil, which entered into recession in 2009 (real contraction of $0.2 \%$ of GDP), India was the second least affected country by the international crisis, second only to China. ${ }^{13}$

Indian growth has been led by the services sector, which accounted for almost $56 \%$ of GDP in 2008/2009, against $34 \%$ in 1970/71. ${ }^{14}$ During the same period, manufacturing also grew, changing its share in the GDP from $22 \%$ to $26 \%$. In contrast, agricultural growth remained slow and erratic and dependent on the weather, especially among small farmers, and its participation in the composition of GDP declined from $44 \%$ to $18 \%$ in this period. ${ }^{15}$

\footnotetext{
${ }^{12}$ Available

at:

https:/www.cia.gov/library/publications/the-worldfactbook/rankorder/2001rank.html?country Name $=$ China\&countryCode $=$ ch\&regionCode $=$ eas\&rank $=3 \# \mathbf{c}$ h Last access: January 2012.

${ }^{13}$ NASSIF, André. Brasil e Índia frente à crise econômica global. BNDES, 2009. Available at: http://www.bndes.gov.br/SiteBNDES/export/sites/default/bndes pt/Galerias/Arquivos/conhecimento/td/ TD-110.pdf Last access: April 2011.

${ }^{14}$ Indian fiscal year starts in April and ends in March.

${ }^{15}$ Ernest \& Young. Doing Business in India. Gurgaon, 2010, p. 19. Available at: http://www.ibef.org/download/Doing_business_in_India_240510.pdf. Last access: April 2011.
} 
Regarding foreign trade, it is worth mentioning that Indian trade flow grew substantially after 2002, reaching USD 539 billion in 2010. The biggest growth was due to increased imports, which resulted in a growing negative balance of trade. More specifically, between 2000 and 2009, exports of goods and services rose strongly, at an average rate of $16 \%$, despite the drop of $7 \%$ in 2009 . In the same period, imports grew at an average rate of $19 \%$, even with a reduction of $7 \%$ in $2009 .{ }^{16}$

According to the $\mathrm{WTO}^{17}$, this rapid economic growth has contributed to the improvement of social indicators, including the decline in child mortality, improvement in sanitation and access to clean water, reducing the percentage of the population living below the poverty line and increasing literacy rates. At the same time, India still faces some major problems such as unemployment, underemployment and deficiencies in the infrastructure sector, particularly in terms of transport and electricity. All these bottlenecks constitute major obstacles for the country to maintain its current growth rate, as well as to achieve the substantially higher growth rates that the government aims. ${ }^{18}$

Another economy that has emerged in the beginning of the $21^{\text {st }}$ century due to its economic dynamism is Russia. ${ }^{19}$ After a period of high instability in the years that followed the end of the Soviet Union, culminating in the external debt moratorium in 1998, the economic scenario has changed radically. Between 1999 and 2008, Russia's GDP grew, on average, 6.8\% per year, there was a moderate recovery in aggregate levels of investment, a significant expansion of the surplus generated by international trade, which has reflected positively on

${ }^{16}$ See World Trade Organization, Trade Profiles 2010. Available at: http://www.wto.org/english/res e/booksp e/anrep e/trade profiles10 e.pdf. Last access: April 2011.

${ }^{17} \mathrm{GDP}$ data obtained at Trade Profiles $O M C$, updated in October 2011. Available at: http://stat.wto.org/CountryProfile/WSDBCountryPFHome.aspx?Language=E. GDP ranking is from CIA World Factbook, 2011, available at: https:/www.cia.gov/library/publications/the-worldfactbook/geos/ch.html. Last access: January 2012.

18 World Trade Organization, "Trade Policy Review - India: Report by Secretariat". Geneva, 2007. Available at: http://www.wto.org/english/tratop_e/tpr_e/tp283_e.htm. Last access: January 2012.

${ }^{19}$ The presented data was collected at: (i) World Bank (http://data.worldbank.org/country/russianfederation, last access in October 2010); (ii) CIA World Factbook (https:/www.cia.gov/library/publications/the-world-factbook/geos/rs.html, last access in October 2010); Russian Federation at Glance - World Bank (http://www.worldbank.org/en/country/russia/overview)

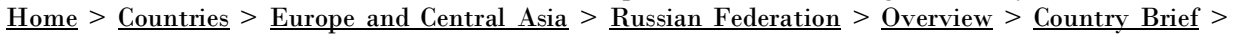
Russia Country Brief, last access in October 2010). 


\section{André Luiz Reis da Silva, Luiza Peruffo}

indicators of external vulnerability as well as on the public sector solvency. It is worth noting that Russian economy's boom can be linked directly to the cycle of rising international prices of energy commodities, among which we point out coal, oil, natural gas, wood. The oil sector, which represents approximately $15 \%$ of Russian GDP and accounts for a quarter of its exports, led the boom seen in the 2000 s and contributed to the fiscal recovery of Russian economy. Exports grew, on average, 16\% per year between 1995 and 2008, from USD 83 billion to USD 468 billion. Imports showed similar growth, expanding at a rate of $15 \%$ per year, reaching USD 293 billion in 2008, against USD 63 billion in 1995. The balances of trade ensured the generation of significant current account surpluses of around 10\% of GDP, considering the average for the 1999-2008 period. The strong accumulation of international reserves reversed the external vulnerability framework present in the period before the 1998 financial crisis.

Thus, before 2008, the Russian economy gave clear signs of overheating. In late 2007 and early 2008, GDP grew at a rate of $8 \%$ per year and domestic demand at $15 \%$ per year, led especially by the recovery in investment levels and the maintenance of robust expansion in consumption. However, this high growth began to change with the deepening of the international financial crisis.

In fact, in 2009, GDP showed a negative variation of $8 \%$ - the biggest drop among the G20 countries - with a sharp contraction in domestic and foreign demand, mainly reflecting the fall in international prices of oil and other commodities. The interruption of external capital flows put strong pressure on the domestic financial system. The fiscal situation also deteriorated, reversing the pre-crisis surplus position of about 5\% of GDP to average deficits between $5 \%$ and $6 \%$ of GDP in 2009-2010. In the following year, GDP grew by $4 \%$, and the current IMF projections point to expected variations of $4.8 \%$ and $4.5 \%$ in 2011 and 2012 , respectively. ${ }^{20}$

According to Guriev and Tsyvinski (2010) ${ }^{21}$, despite high growth rates between 1999 and 2008, Russia has failed to solve many important problems in

${ }^{20}$ See: IMF World Economic Outlook, April 2011, table 1.1. Available at: http://www.imf.org/external/pubs/ft/weo/2011/01/index.htm. Last access: April 2011.

${ }^{21}$ Available at: http://www.piie.com/publications/chapters preview/4976/01iie4976.pdf. Last access: January 2012 . 
the country, especially those relating to corruption and dependency on commodity exports. To these authors, the post-crisis period will be very difficult for Russia, for both external and internal reasons. Lower global growth will probably reflect in lower oil prices in relation to the pre-crisis period, but certainly in lower growth rates in oil prices, which will definitely influence the slower growth of the country. Still according to Guriev and Tsyvinski (2010), future growth will equally depend on the construction of political and economic institutions that ensure property rights, reduce corruption and guarantee the enforcement of contracts and competition.

The Republic of South Africa is one of the major economies in the African continent, having officially joined the group in April 2011, at the BRICS leaders meeting in Sanya, China. In 2009, per capita income in South Africa was USD 6,090 in current values, and USD 10,360 at PPP. ${ }^{22}$ Economic activities are relatively diversified, with services and manufacturing representing respectively $66 \%$ and $17 \%$ of the national income. ${ }^{23}$ Despite its modest contribution to the GDP - 3\% - agriculture remains an important activity, as it absorbs a large share of unskilled labor force. In addition, despite efforts to improve social welfare, about $43 \%$ of the South African population lives below the poverty line of USD 2 per day, according to 2006 data. $^{24}$

Despite high unemployment, low domestic savings, low investment and large current account deficit, South Africa was reaching good economic results. This trajectory, however, was interrupted by the global financial crisis, triggering the first recession in 17 years. Namely, the income of the country contracted $2 \%$ in 2009 , the activities of agriculture, mining and manufacturing declined, foreign trade tightened, the household debt widened, inflation accelerated and the crisis in the country's energy supply system resulted in

\footnotetext{
22 See: http://data.worldbank.org/country/south-africa. Last access: December 2011.

${ }^{23}$ See: http://data.worldbank.org/country/south-africa. Last access: December 2010. Average values for 2005-2009. Total industry accounted for $31 \%$ of income, $17 \%$ originated in the manufacturing industry and $14 \%$ in the extraction industry.

${ }^{24}$ World Trade Organization, "Trade Policy Review - SACU members (Botswana, Lesotho, Namibia, South Africa and Swaziland: Report by Secretariat". Geneva, 2009, p. 281 and 282. Available at: http://www.wto.org/english/tratop_e/tpr_e/tp322_e.htm. Last access: December 2011.
} 


\section{André Luiz Reis da Silva, Luiza Peruffo}

blackouts. Resulting political tension was so huge that Thabo Mbeki, then president of South Africa, resigned in late 2008. ${ }^{25}$

Nevertheless, real GDP growth recovered in $2010(3 \%)$, although this rate remains clearly below potential, estimated at around $4 \%$ per year for South Africa. ${ }^{26} \mathrm{~A}$ wide recovery was mainly driven by renewed global demand for commodities and by the costs related to the 2010 World Cup, as well as by the revival of the automotive industry and the increase of demand for chemicals. ${ }^{27}$ According to the WTO evaluation ${ }^{28}$, solid fiscal and monetary policies, a well regulated financial system and prudential limits of foreign investment helped to limit South Africa's exposure to the crisis. In addition, the country's low public debt facilitated the access to global financing, allowing the government to expand their own spending on areas such as infrastructure and social services.

However, unemployment and poverty remain latent problems in the country, in addition to the shortage of electricity supply, threatening growth prospects in the short term. For growth to be sustainable, South Africa needs to deal with structural issues, such as poor education, which contributes to endemic poverty, inequality and a gap in capabilities, which, in turn, contributes to high levels of unemployment among the poor and unskilled segments of society. The economic impacts of AIDS and crime also pose a major bottleneck to growth.

To sum up, the main results of the development of the BRICS countries in the last decade should be more evident in the coming years. As the Goldman Sachs (2010) report points out, income growth in these countries will create a new and massive middle class - defined as those with annual income between

${ }^{25}$ Africa Can...End Poverty, World Bank blog. Available at: http://blogs.worldbank.org/africacan/theimpact-of-the-financial-crisis-on-south-africa. Last access: December 2011.

${ }^{26}$ AEO - African Economic Outlook. South Africa Overview, 2011. Available at: http://www.africaneconomicoutlook.org/en/countries/southern-africa/south-africa/. Last access: December 2011.

${ }^{27}$ WORLD BANK. South Africa: Country Brief, 2010. Available at: http:/web.worldbank.org/WBSITE/EXTERNAL/COUNTRIES/AFRICAEXT/SOUTHAFRICAEXT

N/0, menuPK:368086 pagePK:141132 piPK:141107 theSitePK:368057,00.html. Last access: December 2011.

${ }^{28}$ World Trade Organization, "Trade Policy Review - SACU members (Botswana, Lesotho, Namibia, South Africa and Swaziland: Report by Secretariat". Geneva, 2009, p. 288. Available at: http://www.wto.org/english/tratop e/tpr e/tp322 e.htm. Last access: December 2011. 
USD 6,000 and USD 30,000. This middle class growth will be led by the two most populous countries in the world, China and India, changing the patterns of global demand. Consequently, it will probably impact the types of products imported by the BRICS, with a likely fall in imports of products with low added value and an increase of products with high added value such as cars, office equipment and technology. ${ }^{29}$

It is worth highlighting that for these remarkable rates of growth to be maintained in the coming years it will be necessary to accelerate investment in infrastructure. Indeed, this type of investment has direct impacts on growth, increasing productivity by allowing the economy to produce more with the same amount of capital and labor. Moreover, improvement in infrastructure also generates indirect positive effects, such as attraction of foreign investment, international trade stimulation, improvement in health and education indicators, and reduction of income disparities (GOLDMAN SACHS, 2011). ${ }^{30}$

For Goldman Sachs (2011), while the large public investment projects in the BRICS seem to be encouraging, they are still insufficient to also attract private capital. Namely, China and India exhibit higher infrastructure growth rates, although they still have a very low level as a standard. In addition, infrastructure in Brazil is relatively underdeveloped and does not have the same growth rates. Russian infrastructure is far more advanced than the others', due to high investments during the Soviet Era, although much of it is harmed due to lack of maintenance. Currently, despite notable improvements in most industries, investment in infrastructure is still insufficient to deal with rapid growth in demand. Thus, in order to the optimistic projections about the future performance of the BRICS to become true, substantial investment in infrastructure projects over the next years will be required (GOLDMAN SACHS, 2011).

29 Available at: http://www2.goldmansachs.com/our-thinking/brics/brics-decade.html. Last access: January 2012.

${ }^{30}$ Available at: $\underline{\text { http://www2.goldmansachs.com/our-thinking/brics/progress-report-on-building- }}$ brics.html. Last access: January 2012. 


\section{BRICS: TRADE POLICY AND RELATIONS WITH BRAZIL}

\subsection{Russia}

In the 1990s, Russia began its commercial liberalization process, as well as the WTO accession process in 1993. Russia established free trade agreements with members of the Commonwealth of Independent States (CIS), so that goods from these countries were exempt from import taxes, although subject to certain conditions, such as avoiding export subsidies. ${ }^{31}$

In 2010, the customs union between Russia, Belarus and Kazakhstan (RBK Customs Union) came into force. With the creation of this common customs area, tariff restrictions regarding movement of goods originating in member countries within the bloc were abolished. ${ }^{32}$ At the multilateral level, Russia's participation in the Asia-Pacific Economic Cooperation (APEC) can be highlighted. ${ }^{33}$ Russia also has several free trade agreements at the bilateral level with countries of the former Soviet zone of influence ${ }^{34}$, and agreements with the United States, Canada and Japan. Such agreements were concluded at the end of the Soviet regime - having been adapted to the Russian Federation, which is the case of the agreement with the U.S., for example - or soon after the collapse of the Soviet system. ${ }^{35}$

The Partnership and Cooperation Agreement, which came into force in 1997, established an institutional framework for regular consultations between the EU and Russia. At the summit in St. Petersburg in May 2003, both strengthened their cooperation by creating four "common spaces" under the Partnership and Cooperation Agreement: one economical; one of freedom, security and justice; one for cooperation in the field of external security; and one for research and education, including cultural aspects. A new partnership

\footnotetext{
${ }^{31}$ Free Trade Agreement between Commonwealth of Independent States - www.worldtradelaw.net. Last access: September 2010.

${ }^{32}$ US Commercial Service, Doing Business in Russia, 2010.

${ }^{33}$ Available

at:

http://www.apec.org/etc/medialib/apec_media_library/downloads/sec/docs/2007.Par.0014.File.v1.1. Last access: September 2010.

${ }^{34}$ Pricewaterhousecoopers. Doing Business and investing in the Russian Federation. 2010.

${ }^{35}$ Available at: http:/www.wto.ru/documents.asp? $\mathrm{f}=$ trade\&t=15. Last access: September 2010.
} 
agreement was discussed and postponed for political reasons ${ }^{36}$, but with the entry of Russia into the WTO, negotiations seem to be taking a more positive direction. ${ }^{37}$

Russian foreign trade structure is characterized by a high concentration of exports in natural resources - two thirds of total exports correspond to fuels and minerals, especially oil and gas, aluminum, coal and forest products. The most prominent imports are machinery and equipment, consumer goods, medicines, meat, sugar and semi-finished metal products. The main destination markets for Russian exports are located in Europe and Asia. Imports originate mainly in Germany, China, Ukraine and Japan.

In trade relations with Brazil, it is worth mentioning that in the recent period, there were temporary embargoes to the export of Brazilian beef to Russia, because of health problems found in some farms in Brazil. ${ }^{38}$ Accordingly, in 2008 a protocol was signed in order to regulate the supply of Brazilian meat to Russia. ${ }^{39}$ Moreover, official dialogue shall be intensified through mechanisms such as the Brazil - Russia Advisory Committee. ${ }^{40}$ Still, it is important to stress that the trade of fresh beef, no matter their species, suffers from several restrictions to enter Russian territory and is governed by the "veterinary regulations in force in the Russian Federation that do not

\footnotetext{
${ }^{36}$ Pricewaterhousecoopers. Doing Business and investing in the Russian Federation. 2010.

${ }^{37}$ European Council, "UE-Rússia: Parceria estratégica no bom caminho". Available at: http://www.european-council.europa.eu/home-page/highlights/eu-russia-strategic-partnership-ontrack.aspx?lang $=$ pt. Last access: September 2011.

${ }^{38}$ In 2004, Russian embargoed any meat from Brazil. Currently, an embargo on meat export to Russia, which has lasted for the past six months, is in effect, reaching producers from Mato Grosso, Paraná and Rio Grande do Sul. Sources: Folha de São Paulo. Exportação de carne bovina cresce, mesmo com aftosa. 27 June 2006. Available at: http://wwwl.folha.uol.com.br/folha/dinheiro/ult91ul08871.shtml, Portal Agronline. Rússia libera exportação de carne brasileira. 30 June 2004 . Available at: http://www.agronline.com.br/agronoticias/noticia.php?id=624 and Portal Rural Br Pecuária. Embargo russo a carnes brasileiras dura seis meses. 15 December 2001. Available at: http://pecuaria.ruralbr.com.br/noticia/2011/12/embargo-russo-a-carnes-brasileiras-completa-seis-meses3597525.html Last access: December 2011.

${ }^{39}$ BRASIL. Ministério da Agricultura, Pecuária e Abastecimento. Intercâmbio Comercial do Agronegócio. 2010. Available at: www.braziltradenet.gov.br/.../PUBIntercambioAgronegocioP.pdf. Last access: April 2011.

40 BRASIL. Ministério da Agricultura, Pecuária e Abastecimento. Intercâmbio Comercial do Agronegócio. 2010. Available at: www.braziltradenet.gov.br/...PUBIntercambioAgronegocioP.pdf. Last access: April 2011.
} 
contradict the Terrestrial Animal Health Code of the WHO". In Brazil, there are some farms authorized by the Russian Federal Service, which are located in the following regions: Pará, Amazonas, Mato Grosso do Sul, Mato Grosso, Minas Gerais, Paraná, Rio Grande do Sul, Goiás, Santa Catarina, São Paulo, Tocantins and Rondônia.

Considering commercial relations between Brazil and Russia since the beginning of the $21^{\text {st }}$ century, there is a clear upward trend in bilateral trade between the two countries. ${ }^{41}$ From 2000 to 2011, Brazilian exports to Russia increased from USD 422 million to over USD 4.2 billion, reaching USD 4.6 billion in 2008. In the same period, Brazilian imports from Russia increased from USD 570 million to USD 2.9 billion, and 2008 was also the year with the largest volume of imports, USD 3.3 billion. In sum, bilateral trade between the two countries, which reached its highest value in 2008 - nearly USD 8 billion increased from USD 993 million to USD 7.1 billion in this period. It is worth noting that there have been constant Brazilian surpluses in trade relations with Russia. Excepting 2000, when Brazil recorded a deficit of USD 147 million, between 2001 and 2011 Brazilian surplus rose from USD 638 million to USD 1.2 billion, reaching surpluses higher than USD 2 billion in 2005, 2006, 2007 and 2010. Figure 1 summarizes the evolution of Russian-Brazilian trade relations.

Figure 1. Bilateral Trade between Brazil and Russia, 2000-2011

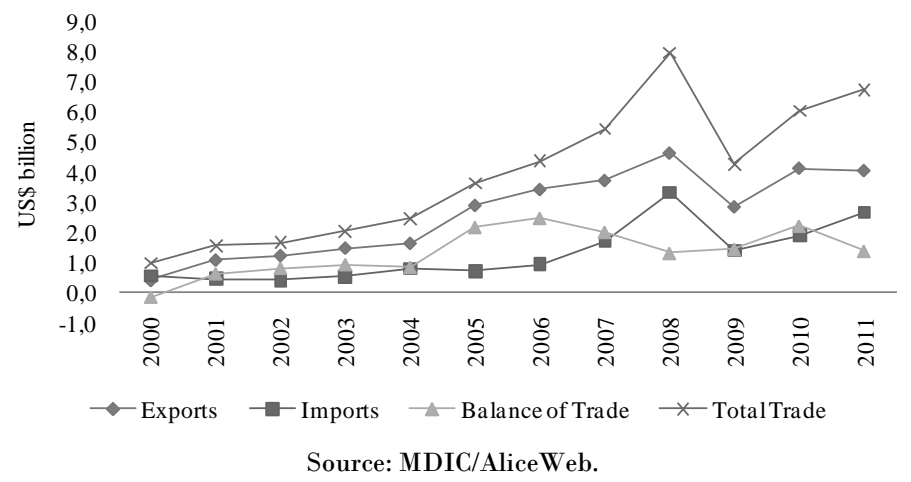

${ }^{41}$ Source of data for trade between Brazil and Russia (balance of trade, major exports and imports): Sistema AliceWeb. Available at: http://aliceweb.desenvolvimento.gov.br/. Last access: January 2012. 
The structure of trade between the two countries has been characterized by the predominance of primary products, mineral extraction or industrial products from industries that process natural resources, on the side of Brazilian exports, and the preponderance of chemicals, on the Russian side of exports. In 2011, Brazilian imports from Russia were led by ammonium nitrate, with a $15.7 \%$ share, equivalent to USD 461 million. In second place was urea nitrogen, representing $15.5 \%$ of exports, USD 455 million. Ammonium dihydrogen orthophosphate ranked third on the list of Russian exports to Brazil, with $14.7 \%$ of the total, USD 431 million.

The roll of Brazilian exports to Russia in 2011 was led by sugar cane, with more than USD 1.8 billion, or $44 \%$ of total exports, characterizing a very concentrated export basket. Brazil also stands out in exports of frozen beef, which responded for more than USD 1 billion in exports (24\% of exports). Other significant products in Brazilian exports to Russia are soy beans and unmanufactured tobacco.

\subsection{India}

India has signed various Regional Trade Agreements in recent years, in order to supplement gains from multilateral trade liberalization. Since the signing of the Bangkok Agreement in 1975, India has mainly joined agreements with other developing countries, with countries in the region (SAFTA) and with some of its neighbors as well. At the same time, India is also seeking to develop links with other regional groupings such as ASEAN and Mercosur. ${ }^{42}$

The South Asian Association for Regional Cooperation (SAARC), an agreement between Bangladesh, Bhutan, India, Maldives, Nepal, Pakistan and Sri Lanka, was established at the first Summit in Dhaka in December 1985. In 1993 members signed the SAARC Preferential Trade Arrangement (SAPTA), which provided preferential limited access to the markets. Afterwards, the Agreement on South Asian Free Trade Area (SAFTA) was signed in 2004.43 The

\footnotetext{
42 World Trade Organization, “Trade Policy Review - India: Report by Secretariat”. Geneva, 2008, p. 24. Available at: http://www.wto.org/english/tratop_e/tpr_e/tp283_e.htm. Last access: April 2011.

${ }^{43}$ Agreement of South Asian Free Trade Area. Available at: http://www.commerce.gov.pk/SAFTA.php. Last access: April 2011.
} 


\section{André Luiz Reis da Silva, Luiza Peruffo}

Asia-Pacific Trade Agreement (APTA) - originally Bangkok Agreement - was signed in 1975 by Bangladesh, India, Laos, Republic of Korea, the Philippines, Sri Lanka and Thailand. China acceded to the agreement in 2001. The APTA came into force in $2006 .{ }^{44}$

The Bay of Bengal Initiative for Multi-Sectoral Technical and Economic Cooperation (BIMSTEC), originally known as BIST-EC, was signed in 1997 by Bangladesh, India, Sri Lanka and Thailand. Later, Myanmar, Nepal and Bhutan also became members. In 2004, BIMSTEC members signed a Framework Agreement to form a free trade area by 2012.45 Under the Generalized System of Preferences (GSP), India gets preferential access to markets of Bulgaria, Canada, the European Union, Japan, New Zealand, Norway, Russia, Turkey, Switzerland and the United States. ${ }^{46}$ India has Bilateral Trade Agreements with several countries, mainly Asian. ${ }^{47}$

Since the beginning of the $2000 \mathrm{~s}$, India has also sought to get closer to ASEAN, having joint an agreement on goods trade, which envisages the gradual creation of a free trade area, which should come into force in 2013 and be complete in 201848; to the European Union, through the EU-India Strategic Partnership, signed in 2005; to the US, by the US-India Trade Policy Forum, whose first meeting was also in $2005^{49}$; to the Southern African Customs Union (2008 Memorandum of Understanding ${ }^{50}$ ); to the Southern African Customs Union (2008 Memorandum of Understanding); and to Mercosur, through the

\footnotetext{
${ }^{44}$ World Trade Organization, “Trade Policy Review - India: Report by Secretariat". Geneva, 2008, p. 26. Available at: http:/www.wto.org/english/tratop e/tpr e/tp283 e.htm. Last access: April 2011.

${ }^{45}$ The Financial Express. BIMSTEC free trade area from july next year. March 2011. Available at: http://www.thefinancialexpress-bd.com/more.php?news_id=128348\&date=2011-03-07. Last access: April 2011.

${ }^{46}$ World Trade Organization, “Trade Policy Review - India: Report by Secretariat". Geneva, 2008, p. 28. Available at: http:/www.wto.org/english/tratop_e/tpr_e/tp283_e.htm. Last access: April 2011.

${ }^{47}$ Information available on the website of the Ministry of Trade and Industry of India. Available at: http://commerce.nic.in/trade/international_ta_current_details.asp. Last access: April 2011.

${ }^{48}$ Agreement on Trade in Goods Under the Framework Agreement on Comprehensive Economic Cooperation Between the Republic of India and the ASEAN. Available at: http://commerce.gov.in/trade/ASEAN-India \%20Trade\%20in\%20Goods\%20Agreement.pdf. Last access: April 2011.

${ }^{49}$ World Trade Organization, “Trade Policy Review - India: Report by Secretariat". Geneva, 2008, p. 27 28. Available at: http://www.wto.org/english/tratop_e/tpr_e/tp283_e.htm. Last access: April 2011.

50 Information collected at the Indian Ministry of Commerce and Industry website. Available at: http://commerce.nic.in/trade/international_ta_current_details.asp. Last access: April 2011.
} 
2003 Framework Agreement to Promote Economic Cooperation and the Preferential Trade Agreement, which was signed in 2004 and came into force in 2009. India has offered commitments on 450 tariff lines at the eight-digit Harmonized System with preferences between $10 \%$ and $100 \%$ of the Most Favored Nation rate to Mercosur. ${ }^{51}$

Trade relations between India and Brazil are institutionalized by the agreement between India and Mercosur, since there are no bilateral trade agreements between the two countries. The decision of President Luiz Inácio Lula da Silva (2003-2010) to strengthen the ties with India has sometimes been criticized, since there were no significant trade relations between the two countries. However, this decision was made in order to start a political alliance from which commercial ties should be strengthened. In fact, Brazil's efforts to strengthen relations with India are part of a broader scope of the Brazilian diplomatic strategy to strengthen the relationship with developing countries, under the logic of South-South Cooperation, one of the hallmarks of the Lula government. ${ }^{2}$ For instance, there is the IBSA, which congregates India, Brazil and South Africa, countries that occupy a position of great multiethnic democracies in the international system and that share similar views on many multilateral issues.

The importance of the Indian market to Brazilian foreign trade has fluctuated over the past years ${ }^{53}$. Still, one can say that since 2006 there has been a steady increase in bilateral trade between them, which rose from USD 2.4 billion in that year to USD 9.2 billion in 2011. Excluding 2000 and 2001, when Brazilian exports totaled less than USD 300 million each year, one can divide them into three periods: 2002-2004, when it stood at around USD 620 million; from 2005 to 2008 , when the average was USD 1 billion; and the last three

\footnotetext{
${ }^{51}$ Information collected at the Indian Ministry of Commerce and Industry website. Available at: http://commerce.nic.in/trade/international_ta_current_details.asp. Last access: April 2011.

52STUENKEL, Oliver. The case for stronger Brazil-India Relations. Indian Foreign Affairs Journal Vol. 5, No 3, July-September 2010, p.290-304. Available at: http://www.gppi.net/fileadmin/media/pub/2011/Stuenkel_2011_India-Brazil-Relations_IFAJ.pdf. Last access: April 2011.

53 Source of Brazil-India trade data (balance of trade, major imports and exports): Sistema AliceWeb. Available at: http://aliceweb.desenvolvimento.gov.br/. Last access: January 2012.
} 
years, 2009-2011, which averaged USD 3.3 billion, with the highest value reached in 2010, USD 3.5 billion.

Regarding Brazilian imports from India, there has seemed to be a general trend of growth during the analyzed period, having evolved from USD 271 million in 2000 to USD 6 billion in 2011. Imports increased consistently since 2003 (USD 485 million), except in 2009 (USD 2.19 billion), when the level was similar to 2007 (2.16 billion). In 2010, Brazilian imports from India reached USD 4.2 billion, exceeding the value verified in 2008 (USD 3.5 billion). Indeed, 2009 was the only year in which Brazil achieved a significant surplus in trade with India (USD 1.2 billion), a result of both a significant increase in exports that year and of an atypical drop in imports. Since 2005, Brazil has growing deficits with India, which reached USD 2.88 billion in 2011.

Figure 2. Bilateral Trade between Brazil and India

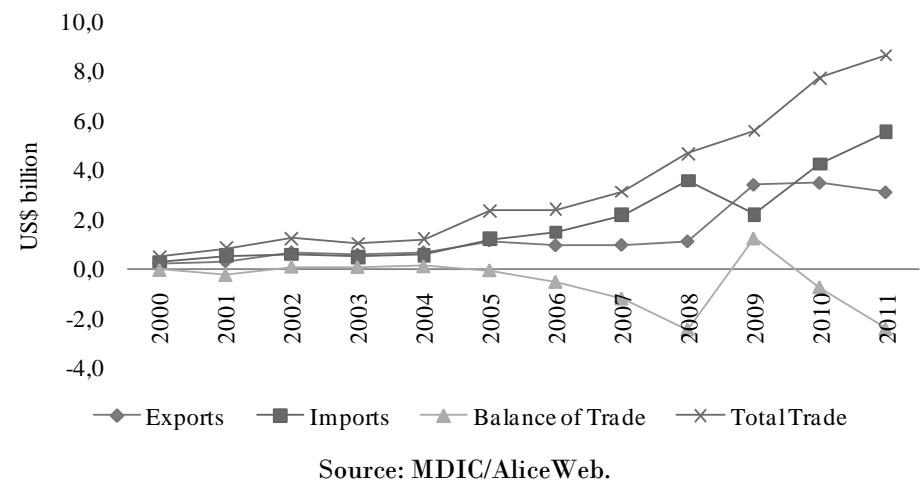

With respect to exported products, both Brazil and India have very concentrated export baskets. Regarding Brazilian exports, crude oil represented $53 \%$ of total exports in 2011, USD 1.7 billion. In second place was sulfide ores of copper, whose value reached USD 419 million, representing just over 13\% of exports. Crude soybean oil came in third place in the major exports ranking, reaching nearly USD 165 million, about $5 \%$ of total exports. The drop in the share of sugarcane in the export basket is noteworthy, once it represented nearly $27 \%$ of total exports (more than USD 850 million) in 2010 and approximately USD 120 million, equivalent to only $3.8 \%$ of exports in 2011 . 
Regarding Indian exports basket to Brazil in 2011, diesel fuel accounted for $51.4 \%$ of exports, reaching a value of over USD 3.1 billion and presenting a significant increase in participation with respect to 2010 , when it represented $41 \%$ of exports. Several textile products are also noteworthy, though none stands out individually.

\subsection{China}

Since the outbreak of the financial crisis, Chinese leaders have clearly stated China's position against protectionist mechanisms in various international forums. President $\mathrm{Hu}$ Jintao joined the other leaders of the G20 commitment not to erect new barriers to investment or goods and services trade, not to impose new export restrictions or implement measures to stimulate exports that are inconsistent with the WTO and promptly correct any measures in this direction. ${ }^{54}$

In 2001, when China signed the entry into the organization, it had to agree to take concrete steps to remove trade barriers and open its markets to foreign companies and their export products. Since it became a WTO member country, China has seen its trade statistics increase dramatically and is now the largest exporter and second largest trader, only behind the United States.

China continues to intensify its search for bilateral and regional free trade agreements, because it believes that such agreements are complementary to the multilateral trading system. Nevertheless, the preferential margins offered by China are still small and trade with its free trade agreement partners still accounts for a small portion of total Chinese trade.

Regionally, China participates in the Asia-Pacific Economic Cooperation (APEC); the Asia-Europe Meeting (ASEM); the cooperation framework of ASEAN +3 (Association of Southeast Asian Nations plus China, Japan and South Korea), and the Asia-Pacific Trade Agreement (APTA, also known as Bangkok Agreement). Under the 2003 Framework Agreement on Comprehensive Economic Cooperation between China and ASEAN, the parties agreed to negotiate the establishment of a Free Trade Area (CAFTA) within ten

${ }^{54}$ WORLD TRADE ORGANIZATION. Trade Policy Review: Report by the secretariat. China. 2010. Available at: http://www.wto.org/english/tratop_e/tpr_e/tp330_e.htm. 


\section{André Luiz Reis da Silva, Luiza Peruffo}

years. CAFTA, involving the original ASEAN 6 (Brunei, Indonesia, Malaysia, Philippines, Singapore and Thailand) was established in $2010^{55}$, with flexibility until 2015 for Cambodia, Laos, Myanmar and Vietnam. In that context, ASEAN and China agreed to strengthen economic cooperation through the strengthening of existing activities and developing new programs in five priority sectors: agriculture, human resource development, information technology and communication, investment, and development of the Mekong River Basin.

China's trade with its existing free trade agreements bilateral partners is responsible for a small and declining part of its trade: exports to these countries fell from $19.6 \%$ in 2006 to $17.5 \%$ in 2009 , and imports reduced from $4.6 \%$ in 2006 to $4.3 \%$ in 2009.56 Regarding other agreements, it is worth mentioning the Framework Agreement on Trade and Economy with Australia, established in 2003; the joint declaration with the Southern African Customs Union (SACU) in 2004; the Framework Agreement on Economic, Commercial, Investment and Technological Cooperation with the Gulf Cooperation Council, also in 2004; and the beginning of negotiations for the establishment of a Free Trade Area with Iceland in 2006; with Norway in 2008; and with Costa Rica in 2009. Moreover, in January 2011, China began negotiations on a Framework Agreement on Economic Cooperation with Chinese Taipei. Recent feasibility studies point to potential negotiations for Free Trade Agreements with India, Korea and Switzerland.

In terms of institutionalized relations between China and Brazil, as a first approximation at the commercial level, one could stand out the agreement signed in 1978 that established the Most Favored Nation clause in trade between the two countries. In 1984, a protocol was added to this agreement, in order to stimulate the achievement of the terms specified in the 1978 agreement. More recently, in 2004, the two countries signed a Memorandum of

55TONG, Sarah Y. \& CHONG ,Catherine Siew Keng, “CHINA-ASEAN FREE TRADE AREA IN 2010: A REGIONAL PERSPECTIVE", EAI Background Brief No. 519, 2010. Available at: http:/www.eai.nus.edu.sg/BB519.pdf. Last access: December 2011.

${ }^{56}$ WORLD TRADE ORGANIZATION. Trade Policy Review: Report by the secretariat. China. 2010. Available at: http:/www.wto.org/english/tratop e/tpr e/tp330 e.htm. The Free Trade Agreement with Peru was signed in April 2009 and should come into force in 2010. 
Understanding on Cooperation in Trade and Investment, in which Brazil recognized China as a market economy. The two countries have also signed commitments to strengthen cooperation in the areas of phytosanitary inspection and regulation to ensure the access of Brazilian products to the Chinese market and vice versa. In this sense, some protocols on animal quarantine and on conditions for the export of these products have been signed recently. ${ }^{57}$

Regarding recent development of trade relations between Brazil and China, one can identify three distinct periods. ${ }^{58}$ The first, between 2000 and 2003 , is characterized by the intensification of a balance that is favorable to Brazil - since, from a deficit of USD 136 million, Brazil went on a surplus of over USD 2 billion. At this stage, Brazilian exports to China rose from just over USD 1 billion to USD 4.5 billion, while imports from China increased from USD 1.2 billion to USD 2.1 billion.

Nonetheless, this trend was interrupted in 2004 when Brazil reduced its trade surplus to USD 1.7 billion, and continued until 2008, year in which Brazil accumulated a deficit of USD 3.5 billion. It is worth noting that between 2004 and 2008 there was a sharp increase in bilateral trade between the two countries. Brazilian exports went from USD 5.4 billion to USD 16.5 billion and imports from China rose from USD 3.7 billion to USD 20 billion.

In the past three years, the balance of trade turned once again very favorable to Brazil: approximately USD 5 billion in 2009 and 2010, and USD 11.5 billion in 2011. During this period, exports grew from USD 21 billion in 2009 to USD 44.3 billion in 2011 and imports from China increased from USD 15.9 billion to USD 32.7 billion. As a result, bilateral trade between the two countries rose from USD 2.3 billion in 2000 to USD 77.1 billion in 2011, and, since 2009, China became the main destination of Brazilian exports. Figure 2 below shows the evolution of bilateral trade between the two countries:

${ }^{57}$ BRASIL. Ministério das Relações Exteriores do Brasil (MRE) - Atos bilaterais assinados com a China. Available at: http://www2.mre.gov.br/dai/bichina.htm. Last access: October 2010.

${ }^{58}$ Source of Brazil-China trade data (balance of trade, major imports and exports): Sistema AliceWeb. Available at: http://aliceweb.desenvolvimento.gov.br/. Last access: January 2012. 
Figure 3. Bilateral Trade between Brazil and China, 2000-2011

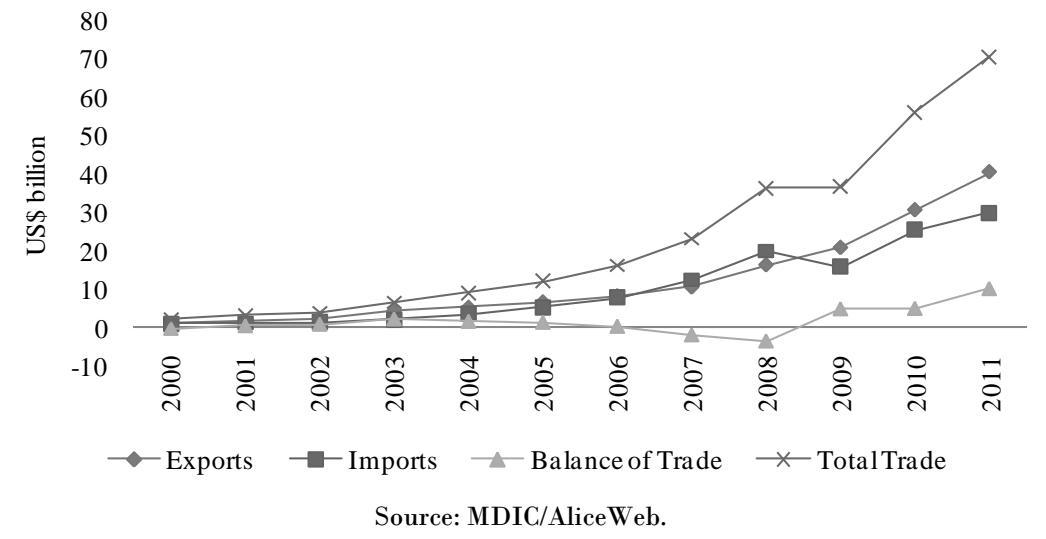

Regarding the export guidelines of each country, Brazil has a very concentrated export basket, with emphasis on three products: iron ore, soybeans and crude oil, which accounted for over $75 \%$ of Brazilian exports to China in 2011. In fact, the export structure of the Chinese industry and the increase in average income in that country seem to have contributed for its imports to focus on metal and agricultural commodities. ${ }^{59}$ In 2011, nonagglomerated iron ore was the most exported product to China, representing $40.6 \%$ of exports. Considering agglomerated and non-agglomerated ore, this figure rises to $44.7 \%$ of Brazilian exports to China, totaling about USD 19.8 billion. In second place, there were soybeans, with $24.7 \%$ of the total (USD 10.9 billion). As mentioned earlier, another highlight is crude oil, which in 2011 accounted for $11 \%$ of total exports to China (USD 4.9 billion).

On the other hand, Chinese exports to Brazil are considerably diversified. Indeed, the sum of the top 100 exported products does not reach $50 \%$ of total exports. Moreover, it is noteworthy that Chinese exports to Brazil are composed of high technology products, i.e., with high added value. As Acioly, Pinto and Dutra (2011) pointed out, the concentration of Brazilian exports, along with the diversification of the Chinese exports, regardless of

\footnotetext{
${ }^{59}$ Boletim Regional do Banco Central do Brasil, Trajetória do Comércio Externo com a China - 2000 a 2010, April 2011. Available at: http://www.bcb.gov.br/pec/boletimregional/port/2011/04/br201104blp.pdf. Last access: December 2010.
} 
Brazilian surpluses in the bilateral relationship, poses the possibility of paralysis as a commodities exporter. ${ }^{60}$ In 2011, the top three products imported from China were other parts for radio broadcast, television, and other receiver devices (USD 1.3 billion, 4.2\% of imports), other parts for telephone/telegraph devices (USD 643 million, 2\%) and portable mobile phone terminals (USD 592 million, $1.8 \%)$.

\subsection{South Africa}

South Africa is a supporter of multilateralism and has played an active role in the GATT/WTO, including the ongoing negotiations of the Doha Development Agenda (DDA), in which it represents a key member of various settings in the areas of agricultural negotiation and of Non-Agricultural Market Access (NAMA).

A new agreement of the Southern African Customs Union (the 2002 SACU agreement) came into force in 2004 providing greater harmonization of policies in several areas. SACU countries are members of the Southern African Development Community (SADC) and have preferential trade agreements with the European Free Trade Association (EFTA) and with Mercosur. SACU countries are eligible for non-reciprocal preferential treatment under the Generalized System of Preferences (GSP) and under the U.S.-African Growth and Opportunity Act (AGOA). For a more harmonized trade policy, SACU members agreed to negotiate new preferential trade agreements as a group. They are finalizing negotiations on economic partnership agreements with the European Community. ${ }^{61}$

During 2008, SACU and Mercosur member states concluded negotiations on a preferential trade agreement (PTA). The new PTA replaces the previous one signed in 2004, based on the understanding between SACU and

${ }^{60}$ ACIOLY, L.; CINTRA, M.; \& PINTO, E. As relações bilaterais Brasil-China: a ascensão da China no sistema mundial e os desafios para o Brasil. Brasília: IPEA, 2011.

${ }^{61}$ World Trade Organization, "Trade Policy Review - SACU members (Botswana, Lesotho, Namibia, South Africa and Swaziland: Report by Secretariat". Geneva, 2009, p. vii-viii. Available at: http://www.wto.org/english/tratop_e/tpr_e/tp322_e.htm. Last access: December 2010. 


\section{André Luiz Reis da Silva, Luiza Peruffo}

Mercosur on the conclusion of their agreement of economic complementation. The PTA has not yet been notified to the WTO. ${ }^{62}$

South Africa has a number of bilateral trade agreements (with Malawi and Zimbabwe for example ${ }^{63}$ ). The most notable is the Trade, Development and Cooperation Agreement (TDCA), signed in 1999 with the European Union, its main trading partner and source of FDI, which provides for the asymmetric liberalization of trade between the two parts, with the intention of forming a free trade area in 2012.

South African products are eligible for non-reciprocal preferences, including lower tariffs or preferential tariffs quotas under the U.S. AGOA and the GSP regimes of the European Union, as well as Canada, Japan, Norway, Switzerland and the United States. ${ }^{64}$ It is important to mention that, according to the Brazilian Ministry of Development, Industry and Foreign Trade website, the Preferential Trade Agreement between SACU and Mercosur has not yet come into force. ${ }^{65}$ South Africa is also part of the IBSA (India, Brazil and South Africa). ${ }^{66}$ As for business relations between Brazil and South Africa, there are no major implications bilaterally institutionalized, with agreements being restricted to the multilateral level, such as IBSA and the preferential trade agreement between SACU and Mercosur.

Trade flow between Brazil and South Africa increased consistently between 2000 and 2008, from USD 529 million to USD 2.5 billion. ${ }^{67}$ In 2009 , this trend was interrupted, falling to USD 1.7 billion, but growing again in the following biennium, reaching USD 2.6 billion in 2011. Similarly, Brazilian

\footnotetext{
${ }^{62}$ World Trade Organization, "Trade Policy Review - SACU members (Botswana, Lesotho, Namibia, South Africa and Swaziland: Report by Secretariat". Geneva, 2009, p. 14-15. Available at: http://www.wto.org/english/tratop_e/tpr_e/tp322_e.htm. Last access: December 2010.

${ }^{63}$ For a description of the preferential tariff treatment for Mozambique, see WTO (1998).

World Trade Organization, "Trade Policy Review - SACU members (Botswana, Lesotho, Namibia, South Africa and Swaziland: Report by Secretariat". Geneva, 2009, p. 293. Available at: http:/www.wto.org/english/tratop_e/tpr_e/tp322_e.htm. Last access: December 2010.

${ }^{65}$ Ministério do Desenvolvimento, Indústria e Comércio Exterior (MDIC), "Acordo MERCOSUL/SACU". Available at: http://www.mdic.gov.br//sitio/interna/interna.php?area=5\&menu=576. Last access: December 2010.

${ }^{66}$ IBSA Trilateral Official Website. About IBSA. Available at: http://www.ibsa-trilateral.org/. Last access: December 2010.

${ }^{67}$ Source of Brazil-South Africa trade data (balance of trade, major imports and exports): Sistema AliceWeb. Available at: http://aliceweb.desenvolvimento.gov.br/. Last access: January 2012.
} 
exports to South Africa evolved positively between 2000 (USD 302 million) and 2007 (USD 1.7 billion), falling slightly in 2008 and more sharply in 2009 (USD 1.2 billion), but recovering its growth in 2010 (USD 1.3 billion) and 2011 (USD 1.7 billion). Regarding South African imports, they presented a positive variation between 2002 (USD 181 million) and 2008 (USD 774 million), falling to USD 433 million in 2009, but recovering in 2010 (USD 753 million) and 2011 (USD 911 million), when the highest value in the period was reached. Finally, it is worth noting that bilateral trade between Brazil and South Africa is characterized by recurrent favorable balances to Brazil. In 2011, Brazilian surplus was USD 768 million, higher than that of the previous year (USD 556 million), but below the average of USD 1 billion recorded in the 2005-2008 period. Figure 4 below summarizes this statistics.

Figure 4. Bilateral Trade between Brazil and South Africa, 2000-2011

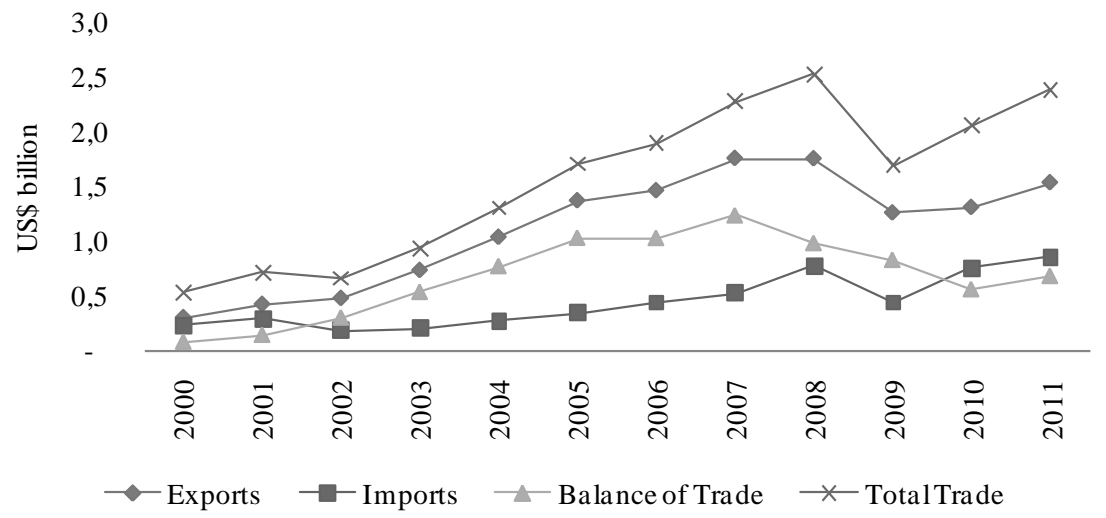

Source: MDIC/AliceWeb.

Regarding Brazilian exports to the African country, the export basket is relatively diversified. In 2011, for example, the top 10 products accounted for approximately $42 \%$ of total exports. The leading products were frozen chicken cuts and offal, representing $11.5 \%$ of the total, equivalent to approximately USD 192 million. The second most exported products were automotive vehicles with combustion engine and maximum load of 5 tons, with $6.5 \%$ of the total, 
equivalent to just over USD 109 million. The third most exported products in 2011 were road tractors for semi-trailers, which accounted for just $6 \%$ of the total, USD 96.8 million.

Regarding Brazilian imports originating in South Africa, nonagglomerated anthracite coal was the main imported product, accounting for nearly $13 \%$ of the total, equivalent to approximately USD 116 million, followed by internal combustion engines for vehicles, with almost $8 \%$ of the total, about USD 71 million. In third place was palladium, unwrought or in powder form, accounting for $6.1 \%$ of the total, approximately USD 56 million.

\section{CONCLUSIONS}

Since 2001, when the term BRIC was created, there has been a remarkable evolution of the role played by these countries in both the international economy and the political arena. Indeed, over the past decade, Brazil, Russia, India and China have contributed to more than a third of the world's GDP growth and, at the same time, they now account for almost one quarter of the world economy against a sixth in 2001 (in terms of Purchasing Power Parity PPP). Although it presents more modest figures, South Africa is one of the major economies of the African continent, having joined the group officially in April 2011, at the BRICS leaders meeting in Sanya, China.

On the other hand, it seems that the current international crisis is contributing to further accentuate the position of emerging economies have, to the extent that, in general, these countries have experienced fainter real and financial impacts than the advanced economies, resuming their previous growth trajectories with relative brevity.

By analyzing bilateral trade between Brazil and the other BRICS countries, one can point out some general trends. The first one - and perhaps the most obvious - is the large increase in levels of trade between Brazil and these countries in the last decade, as illustrated by Figure 5 below. 
Figure 5. Bilateral Trade between Brazil and the other BRICS, 2000-2011

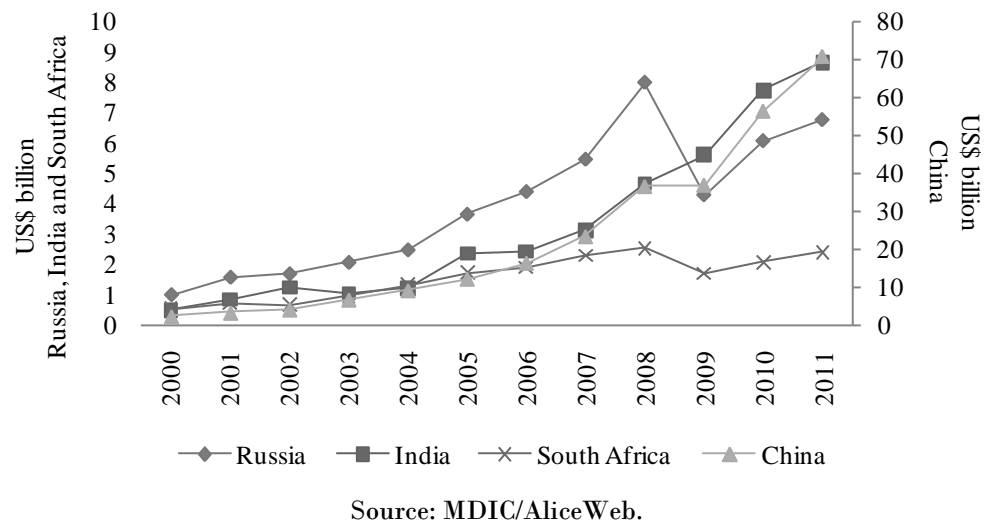

The second is that Brazil has a surplus in these bilateral engagements except in trade with India. The third is the concentration of total Brazilian exports in a few products, usually of agricultural or mineral origin, i.e., with low added value - the exception here is the relatively diversified list of exports to South Africa. The fourth and final trend observed is the fast recovery rates of bilateral trade after 2009. In the case of India, bilateral trade did not go down; in the case of China, it remained stagnated in 2009 and surged again in the following years; finally, in the cases of South Africa and Russia, they both dropped in 2009, although bilateral trade with South Africa has almost recovered 2008 levels while trade with Russia still has not.

To sum up, our results suggest that bilateral trade between Brazil and the other BRICS countries, which cannot be characterized as traditional trade partners, has been assuming an increasing importance. Bearing in mind the limits of this research, one could argue that the trend of empowerment of emerging countries also seems to be appearing in the international merchandise trade between Brazil and the other BRICS. 


\section{André Luiz Reis da Silva, Luiza Peruffo}

\section{REFERENCES}

"The Key Indicators for Asia and the Pacific 2010". Available at: http://www.adb.org/Documents/Books/Key Indicators/2010/Country.asp. Last access: November 2010.

ACIOLY, L.; CINTRA, M.; \& PINTO, E. As relações bilaterais Brasil-China: a ascensão da China no sistema mundial e os desafios para o Brasil. Brasília: IPEA, 2011.

AEO - African Economic Outlook. South Africa Overview, 2011. Available at: http://www.africaneconomicoutlook.org/en/countries/southern-africa/southafrica/. Last access: December 2011.

Africa Can...End Poverty, World Bank blog. Available at: http://blogs.worldbank.org/africacan/the-impact-of-the-financial-crisis-onsouth-africa. Last access: December 2010.

BHATIA, Rajiv. BRICS set to outshine IBSA? The Hindu, 30 de abril de 2011. Available

http://www.hindu.com/2011/04/30/stories/2011043055861200.htm. Last access: April 2011.

BRASIL. Ministério da Agricultura, Pecuária e Abastecimento. Intercâmbio Comercial do Agronegócio. $2010 . \quad$ Available at: www.braziltradenet.gov.br/.../PUBIntercambioAgronegocioP.pdf. Last access: April 2011.

BRASIL. Ministério das Relações Exteriores do Brasil (MRE). Atos bilaterais assinados com a China. Available at: http://www2.mre.gov.br/dai/bichina.htm. Last access: October 2010.

CANUTO, O., GIUGALE, M (Editors). The Day After Tomorrow: a handbook on the future of economic policy in the developing world. Washington, DC: The World Bank, 2010.

CIA World Factbook, 2011. Available at: https://www.cia.gov/library/publications/theworld-factbook/geos/ch.html. Last access: December 2011.

CUNHA, André. Crescimento e Internacionalização na China: Impactos Potenciais na América Latina Área 18. Brasil e América Latina no Capitalismo Contemporâneo. Sessões Ordinárias. Available at: http://www.sep.org.br/artigo/2_congresso/_804_la06ce240cf45c98fd5dbblacf 79c838.pdf. Last access: December 2011.

EAC - Economic Advisory Council to the Prime Minister. Economic Outlook for 2010/11. Available at: http://eac.gov.in/reports/ecoout 1011.pdf. Last access: December 2011.

EL-ERIAN, M. When Markets Collide: investment strategies for age of global economic change. New York, McGraw Hill, 2009.

Ernest \& Young. Doing Business in India. Gurgaon, 2010, p. 19. Available at: http://www.ibef.org/download/Doing business in India 240510.pdf. Last access: April 2011. 
European Council, "UE-Rússia: Parceria estratégica no bom caminho". Available at: http://www.european-council.europa.eu/home-page/highlights/eu-russiastrategic-partnership-on-track.aspx?lang=pt. Last access: December 2011.

FMI. World Economic Outlook, 2011. Available at: http:/www.imf.org/external/pubs/ft/weo/2011/01/weodata/weoselser.aspx?c= $\underline{534 \& \mathrm{t}=1}$. Last access: April 2011.

GROSS, B. On the "Course" to a New Normal. Investment Outlook, September. PIMCO, 2009. Available at: http://www.pimco.com/LeftNav/Featured+Market+Commentary/IO/2009/Gr oss $+\mathrm{Sept}+\mathrm{On}+$ the + Course + to $+\mathrm{a}+\mathrm{New}+$ Normal.htm. Last access: January 2012.

GRYNBERG, Roman, “Towards a developmental SACU”, Mmegi Online. Available at: http://www.mmegi.bw/index.php?sid=4\&aid=632\&dir=2011/July/Friday 29 . Last access: December 2011.

MORRINSON, Wayne M. Congressional Research Service - China's Economic Conditions, 2011. Available at: http://www.fas.org/sgp/crs/row/RL33534.pdf. Last access: December 2011.

NASSIF, André. Brasil e Índia frente à crise econômica global. BNDES, 2009. Available at:

http://www.bndes.gov.br/SiteBNDES/export/sites/default/bndes pt/Galerias/ Arquivos/conhecimento/td/TD-110.pdf. Last access: April 2011.

National Bureau of Statistics of China, "China Statistical Yearbook 2007". Available at: http://www.stats.gov.cn/tjsj/ndsj/2007/indexeh.htm. Last access: February 2009.

SERBANK. Forecast of Russian Economy Development for 2010-2011 and 2012-2013, July 2010. Available at: http://www.sbrf.ru/common/img/uploaded/files/pdf/press center/Review fore cast_2010_2013_en.pdf. Last access: December 2011.

SPENCE, M. Emerging Financial Markets after the Global Financial Crisis. PIMCO Viewpoints, August. PIMCO, 2009. Available at: http:/www.pimco.com/LeftNav/Viewpoints/2009/Emerging+Financial+Mar kets + Spence+August.htm Last access: January 2012.

STUENKEL, Oliver. The case for stronger Brazil-India Relations. Indian Foreign Affairs Journal, vol. 5, n. 3, p. 290-304, July - September 2010. Available at: http:/www.gppi.net/fileadmin/media/pub/2011/Stuenkel 2011 India-BrazilRelations IFAJ.pdf. Last access: April 2011.

TONG, Sarah Y. \& CHONG, Catherine Siew Keng, "CHINA-ASEAN FREE TRADE AREA IN 2010: A REGIONAL PERSPECTIVE”, EAI Background Brief No. 519, 2010. Available at: http://www.eai.nus.edu.sg/BB519.pdf. Last access: December 2011.

UNDP, Human Development Report - Sustainability and Equity: A Better Future for All, 2011.

Available at: 


\section{André Luiz Reis da Silva, Luiza Peruffo}

http://hdrstats.undp.org/images/explanations/RUS.pdf. Last access: December 2011.

WHITE AND WILLIAMS, China's Economy in 2011, 2011. Available at: http://www.whiteandwilliams.com/resources-alerts-9.html. Last access: December 2011.

WORLD BANK. China Overview, 2011. Available at:

http://www.worldbank.org/en/country/china/overview. Last access: December 2011.

WORLD BANK. India Country Overview, 2011. Available at: http://www.worldbank.org.in/WBSITE/EXTERNAL/COUNTRIES/SOUTH ASIAEXT/INDIAEXTN/0, contentMDK:20195738 pagePK:141137 piPK: 141127 theSitePK:295584,00.html. Last access: December 2011.

WORLD BANK. South Africa: Country Brief, 2010. Available at: http:/web.worldbank.org/WBSITE/EXTERNAL/COUNTRIES/AFRICAE XT/SOUTHAFRICAEXTN/0,,menuPK:368086 pagePK:141132 piPK:141 107 theSitePK:368057,00.html. Last access: December 2011.

World Development Indicators 2010, special China table. Available at: http://data.worldbank.org/country/china. Last access: November 2010.

World Economic Outlook, April 2011. Available at: http://www.imf.org/external/pubs/ft/weo/2011/01/index.htm. Last access: April 2011.

World Trade Organization, "Trade Policy Review - SACU members (Botswana, Lesotho, Namibia, South Africa and Swaziland: Report by Secretariat". Geneva, 2009, p. 281. Available at: http://www.wto.org/english/tratop e/tpr e/tp322 e.htm. Last access: December 2010.

WTO - World Trade Organization, Trade Profiles 2010. Available at: http://www.wto.org/english/res_e/booksp_e/anrep_e/trade_profiles10_e.pdf. Last access: April 2011.

\section{Primary Sources}

Sistema Alice Web (http://alice.desenvolvimento.gov.br/)

Ministério do Desenvolvimento, Indústria e Comércio Exterior (MDIC) (http://www.mdic.gov.br/)

Folha de São Paulo (http://www.folha.uol.com.br)

Portal Agronline (http://agronline.com.br/)

Portal Rural Br Pecuária (http://pecuaria.ruralbr.com.br/)

Apex-Brasil (http://www.apexbrasil.com.br/) 


\begin{abstract}
This article analyzes the impact of the recent international crisis on commercial relations between Brazil and the other BRICS countries (Russia, India, China and South Africa). The methodology consisted of the analysis of governments' and international organizations' documents and reports on international trade. To perform the analysis, firstly, an overview on the general characteristics of the economies of these four trading partners is presented, especially regarding the consequences of the international crisis in each of these economies. After that, the trade relations of the four countries with Brazil in the last decade are reviewed. Our results suggest that bilateral trade between Brazil and the other BRICS countries, which are not characterized as traditional trade partners, has been assuming an increasing importance.
\end{abstract}

\title{
KEYWORDS
}

BRICS; Crisis; Trade. 


\title{
MEDIA AND FOREIGN POLICY IN LULA'S BRAZIL
}

\author{
Guilherme Stolle Paixão e Casarões ${ }^{1}$
}

\section{Introduction}

The interaction between the mass media and foreign policy in Brazil has always been a delicate one, slight at most times, but never meaningless. It has become commonplace to say that, due to the virtual monopoly the Brazilian Foreign Ministry (Itamaraty) has enjoyed over foreign policymaking from the early days of its most important chancellor, Barão do Rio Branco (1902-1912), public debate on the country's goals and strategies has never really taken place (CHEIBUB, 1985; LIMA, 2000; FARIA, 2008). Instead, diplomacy has been by far one of the most undisputed public issues throughout the twentieth century, having survived two long authoritarian periods and several political upheavals. When the first civil president was elected in early 1985, after two decades of military regime, he is said to have decided to keep foreign policy untouched for it represented a supra-partisan consensus that had successfully pushed development forward (RICUPERO, 2001).

Only recently have some studies unveiled the role of public opinion and the mass media in times when foreign policy goals were subject to controversy (MANZUR, 1999; 2009; FRANCO, 2009; FERREIRA, 2009). What these works suggest is that public debate over foreign policy goals grows more intense as polarization within Itamaraty becomes salient. Although such relationship seems quite obvious at first, it is not that much straightforward for two reasons.

\footnotetext{
1 Teacher of undergraduate courses in International Relations (Faculdades Integradas Rio Branco FIRB - and Fundação Armando Alvares Penteado - FAAP) and a post-Graduate (lato sensu) in International Relations at FAAP. (casaroes@gmail.com)
} 
First, the strong esprit de corps that marks Brazil's diplomatic service does not allow for open disagreements within the Foreign Ministry to reach public knowledge (CHEIBUB, 1985; BARROS, 1986). That is why identifying different groups and ideological strands among diplomats has always been a daunting task, having only recently received systematic academic scrutiny (SARAIVA, 2010; CASARÕES, 2012). In any case, we may consider that polarization - in the sense that these ideologically-divergent groups come into being and eventually coexist - is much more recurrent than the debate itself.

Second, such debate is not genuinely public. When it takes place, it is carried out through the hands of politicians (who have attacked, sometimes fiercely, the nationalist stances of Getúlio Vargas and João Goulart) or the diplomats themselves (as in the case of Ambassador Roberto Campos against the main lines of Figueiredo's third-world diplomacy in the early 1980s). Scholars, businesspeople, or journalists have usually been on the fringes of this discussion, which had in the newspapers and magazines its most active battlefield. Strictly speaking, however, it hardly reached the general audience, insofar as foreign policy did not involve direct distributive issues or have any political or electoral appeal.

It is fair to assume that the 1990 s represented a turning point in the relationship between the mass media, public opinion, and foreign policy. The new democratic background, consolidated by the Constitution of October 1988, has progressively increased the involvement of an ever more active civil society in foreign affairs. Economic liberalization measures, undertaken by presidents Collor de Mello and Fernando Henrique Cardoso in the wake of that decade, helped increase the distributive character of foreign policy. When Luiz Inácio Lula da Silva took office in January 2003, he decided to make Brazil's external relations both an instrument for development and a source of prestige - at home and abroad. Never before had foreign policy been so close to the daily life of the citizens. It has also turned into a source of discontent (and opportunity) for the opposition to Lula's administration. From retired ambassadors to renowned scholars, from politicians to journalists, critics often appeared on the pages of newspapers and magazines, in articles and op-eds, underscoring the government's gaffes and misdeeds in foreign affairs.

This article looks at this new relationship, in the light of two concurrent trends: the pluralization of actors with stakes in foreign policy; and an active 
presidential diplomacy (CASON; POWER, 2009). We argue that, more than just a battlefield of ideas, Brazil's most prominent media vehicles have played an active role against Lula's foreign policy, although they had but a limited agenda-setting capacity. To this end, the text will be divided in four sections. The first one deals with the recent developments of foreign policymaking in Brazil, and seeks to understand how the introduction of new actors and institutions has affected the political balance behind the country's external relations. The second provides an overview of Lula's foreign policy strategies and their relationship with presidential diplomacy. The third offers some data on the behavior of two selected newspapers, Folha de São Paulo (FSP) and $O$ Estado de São Paulo (OESP), on foreign policy issues. The third and final section compares media reactions to Brazil's relations with the United States, most specifically regarding negotiations on the Free Trade Area of the Americas (FTAA), and to some aspects of Brazilian South-South cooperation, and discusses the most relevant results.

Contemporary trends in Brazilian foreign policy: pluralization and presidentialization

Brazil is, in hindsight, one of the late twentieth-century middle-powers that have shown a great deal of continuity in its foreign relations. This is true at least for the period from 1930 through 1990, when the country ostensibly used its foreign policy with a view to attaining national development goals (LIMA, 1994; CERVO; BUENO, 2002). Strategies of development have surely varied, oscillating between a pro-U.S., foreign capital-dependent as in the governments of Eurico Dutra (1946-1950) or Castello Branco (1964-1967), and a thirdworldist, nationalist model as in the 'independent foreign policy' of Jânio Quadros and João Goulart or the 'responsible pragmatism' of Ernesto Geisel (1974-1979). However, the intimate relationship between the developmentalist state and its foreign strategies has been relatively constant over the years.

The country's diplomatic values, principles, and methods have also stayed very much the same. This is due to the strong legacy of Barão do Rio Branco, who is said to have introduced a diplomacy based on the rule of law, the utmost respect for national sovereignty, the pacific settlement of disputes, and multilateralism - known in his days as 'parliamentary diplomacy' 
(LAFER, 2001). The sense of corporate unity built by Rio Branco during his decade-long tenure as foreign minister, and the myth around his image that has emerged after his death, have contributed to what is known as one of the most stable and coherent institutions in Brazilian politics, and one of the most well acknowledged diplomatic services to date (CHEIBUB, 1985; BARROS, 1986).

Despite the longevity of values, methods, and goals, Brazilian foreign policy has undergone major changes since the beginning of the Nova República in the mid-1980s. These changes became more evident throughout the following decade, with severe impacts on foreign policymaking both at the level of formulation and implementation. In this sense, the democratic opening that has characterized Brazil's new political moment had two important outcomes: first, it has created demands for transparency and accountability that could undermine Itamaraty's 'bureaucratic insulation' (and therefore its monopoly over foreign affairs) in the long run. After all, the very excellence of the nation's diplomacy rested on a considerable degree of elitism and closeness. Secondly, it has paved the ground for the emergence of new actors within the civil society that had some interest in international affairs, from labor unions to human rights activists to businesspeople, which also put pressure on the Foreign Ministry (FARIA, 2008).

Trade liberalization has also changed how foreign policy was made, and who made it. The centrality of trade to the country's diplomatic activities had already been acknowledged in the early 1970, when the Department for Trade Promotion was created as a core branch of the ministry (BARROS, 1986). Nevertheless, only with the economic opening promoted by the 'neoliberal' presidents Collor de Mello and Cardoso did foreign policy turn into a genuinely distributive issue. Some key business sectors (such as computers or automotives), whose competitiveness were otherwise assured by the government, had to come to terms with trends such as globalization and regional integration (KINGSTONE, 1999). The more issues such as trade regulation and tariffs reform became salient, the greater the engagement of other federal agencies, such as the Ministry of Economy (CASTELAN, 2010), and of private actors in trade policies (MANCUSO; OLIVEIRA, 2006).

In sum, the rise of democracy and market-oriented policies in Brazil has impacted on foreign policymaking in two ways. The first and most important one is the pluralization of actors who had a stake in diplomatic affairs. From a 


\section{Guilherme Stolle Paixão e Casarões}

societal standpoint, labor unions were particularly concerned with the development of regional integration, and made an effort to intervene in negotiations on the Common Market of the South (Mercosur) and on the Free Trade Area of the Americas (FTAA) (VIGEVANI; MARIANO, 2005). Businesspeople shared similar concerns, especially when competitiveness was at risk. The automotive sector, for example, pushed Brazil towards trade disputes with the Argentine industry and with developed countries at the World Trade Organization (WTO) (VEIGA, 2005). Political parties, on their part, started trying to reap the electoral potential of foreign policy issues as trade liberalization became a centerpiece of the political agenda (OLIVEIRA; ONUKI, 2010). Finally, a number of non-governmental organizations could voice their demands in areas in which Brazil got progressively involved, such as environmental protection (LAGO, 2006) and human rights (HADDAD, 2005).

All these actors have, to a greater or lesser extent, enough political clout to set the agenda in their respective areas of interest, or at least to tip the balance to their favor. There are other agents, however, who do not have agenda-setting powers, be it due to the lack of political leverage, or simply because their stakes are low. The academic community and the mass media usually fall in this category. Although they are important sources of ideas and the quintessential venues for public debate, their relationship with Itamaraty is often thin, and at most times peripheral (FONSECA JUNIOR, 2011). Why, then, has the role of the mass media changed in recent years?

That is why we must understand the second trend of contemporary Brazilian foreign policy, presidentialization. Presidential diplomacy is usually identified with strong chiefs of executive, as in the postwar United States or in the French Fourth Republic. It has become a reality in Brazil in the late 1980s, when the country's foreign credibility was painfully at stake and regional integration was on the move (MALAMUD, 2005), and grew more intense in the Cardoso and Lula years (CASON;POWER, 2009). This is also due to the rise of multilateralism and, following its course, the advent of the so-called "summit diplomacy' (DANESE, 1999), in which Brazil has intensely taken part. This new diplomatic reality, in which presidents are active international stakeholders and multilateral summits take place quite often, has also changed the relationship between public opinion, the mass media, and foreign policy. As 
long as foreign policy is closely associated with the president, his acts abroad naturally receive more media attention, and diplomacy is forced to become more accountable, which also contributes to the politicization of international affairs. This seems to be precisely the case of Lula's Brazil, which we will explore next.

\section{Lula's foreign policy strategies and the role of a charismatic leader}

When Luiz Inácio Lula da Silva won the presidential race in November 2002, many sectors of the Brazilian society held their breath. Regardless of the promises Lula had made (as a candidate) in order to assure citizens, elites, and foreign markets that no economic or political rollback would take place, some still doubted that a former metal worker and union leader and his Workers' Party (Partido dos Trabalhadores, PT) could keep the nation on track. After all, many expected an unprepared president leading an ideological government (VIZENTINI, 2011) in difficult times - at home and abroad.

The greatest challenge the recently-elected President Lula had to overcome was economic rather than political. In order to live up to his promises - most of them vowed in his 'Letter to the Brazilian People', issued in early 2002 - he decided to embrace economic orthodoxy. By pushing interest rates to the sky, the government wanted to bring inflation down and stop currency devaluation (COUTO; BAIA, 2004). It further deepened the recession for some time, and growth rates would only recover by Lula's second year in office. Yet, such moves allowed the President to gradually gain confidence among middleclass citizens, businesspeople, and foreign markets.

Orthodox measures, however, came with a price. Many in his own party (and among his most loyal supporters, intellectuals and workers alike) dismissed what they called the 'triumph of neoliberal hegemony' (BOITO JR., 2003). This is probably why Lula decided to make a turn to the left in two key areas of policymaking: social programs (with the launch of the Fome Zero and Bolsa Familia programs in 2003) and foreign policy. With respect to the latter, Almeida (2004: 162) underlines that diplomacy is "the strand of government activity that most resembles the old proposals and the traditional guidelines of the Workers' Party' at the outset of Lula's first term. Moreover, 'the inclusion of the social agenda as a major topic of foreign affairs' was an important 


\section{Guilherme Stolle Paixão e Casarões}

innovation that also reflected this unique political approach (LIMA; HIRST, 2006).

'Change' was, in fact, an idea that has characterized the new administration's foreign policy since the 2002 elections (VIGEVANI; CEPALUNI, 2007). Among the proposals outlined in Lula's electoral platform were "the defense of national sovereignty', "the struggle for a radically different world order', 'cooperation with emerging powers, such as China, India, and South Africa', 'the strengthening of Mercosur', and 'the rejection of the FTAA proposal as it is' (FORTES, 2011). Although some of the principles that guided President Lula's international relations had already been evoked by his predecessor a couple of years before, they assumed a new face under the Workers' Party government, with a distinct conceptual emphasis (ALMEIDA, 2004). In fact, Foreign Minister Celso Amorim made an effort to draw a line between Cardoso's foreign policy and his government's own, stressing rupture rather than continuity, as stated in his inauguration speech: "we have to take this posture of responsible and confident activism to foreign relations. We will not shy away from an engaged protagonism, whenever there is need to defend the national interest and the values that inspire us (AMORIM, 2011: 14, emphasis added).

In sum, we may posit that Lula's foreign policy guidelines, while maintaining many of the principles of Cardoso's diplomacy (such as the quest for autonomy in foreign policymaking, the need for regional integration, and the defense of democracy in South America), went beyond the desire to make Brazil a 'global trader'. The new government's aspiration was to drive the country towards a more prominent international role, so that it could become a 'global player' in world affairs. To achieve this, President Lula adopted a strategy of 'autonomy through diversification', by which the country would adhere to 'international norms and principles by means of South-South alliances, including regional alliances, and through agreements with nontraditional partners (China, Asia-Pacific, Africa, Eastern Europe, Middle East, etc), trying to reduce asymmetries in external relations with powerful countries' (VIGEVANI; CEPALUNI, 2007: 1313). Attaining a permanent seat on the United Nations Security Council was, of course, an inseparable part of this strategy (HIRST; LIMA; PINHEIRO, 2010). 
'Autonomy through diversification' did not exclude the foreign strategy that had prevailed over the previous decade, 'autonomy through participation', which was oriented by values and towards the participation in international (liberal) regimes (cf. VIGEVANI; OLIVEIRA; CINTRA, 2003). The predominantly 'grotian' approach to world politics (PINHEIRO, 2000), however, was replaced by a more 'realist' one, in which Western and liberal values played a minor part and that gave way to economic and political pragmatism. Such realism could be observed in a number of situations over the course of the Lula administration: the establishment of alliances in the developing world, especially with intermediate powers, such as the IBSA Forum (OLIVEIRA; ONUKI; OLIVEIRA, 2006; VIEIRA; ALDEN, 2011); the trade G20 at the Doha Round of the WTO (VISENTINI, 2005; CARVALHO, 2010) or the BRICS initiative (FLEMES, 2010); the country's bid for regional leadership in South America (MALAMUD, 2011); and the strategic relationship with developed nations, most notably with the United States (PECEQUILO, $2010)$.

While these strategies have achieved different degrees of success, all can be understood as attempts at affirming Brazil's power abroad and garnering global recognition. Furthermore, they have combined an intense diplomatic work with the charismatic image of President Lula (and, to a lesser extent, of foreign minister Amorim). Ricupero (2010) has appropriately called Lula da Silva's foreign policy a 'personal and nontransferable' one, stressing that most of its achievements rested on the president's magnetism and political skills. Likewise, he was charged for the diplomatic mistakes or failures that might have taken place. That is why most attacks against Brazilian international relations over the Lula years were not always directed to Itamaraty, but to the president himself, and to individuals and groups whose positions were associated to him - such as Marco Aurélio Garcia, Samuel Pinheiro Guimarães, and the ones in the foreign service who identified themselves with nationalist policies, to the detriment of liberal-internationalist ones (SARAIVA, 2010). The case of Folha and Estado seem of particular interest and will be explored in the following section. 


\section{Guilherme Stolle Paixão e Casarões}

The role of the print vehicles: how did they change with respect to foreign policy?

Up until the early 2000 s, the mass media had been but a 'minor actor' in foreign policy issues. They had rarely shown an agenda of their own. At best, what they did was to provide a platform for individual actors, such as politicians, business leaders, or even diplomats to express their opinions on specific events or decisions involving the diplomatic service. Editorial lines of newspapers, regardless of their alignment with (or sympathy towards) political ideologies or specific governments, usually gave little attention to foreign policy.

Let us consider two of the most important newspapers in Brazil, Folha de São Paulo and $O$ Estado de São Paulo. They have consistently ranked among the country's five most circulated newspapers, with a nationwide average 250,000 daily copies for Estado and 300,000 for Folha (ASSOCIAÇÃO NACIONAL DE JORNAIS, 2012) ${ }^{2}$. As Vieira de Jesus (2009) points out, Folha de São Paulo - the country's most read newspaper in the last two decades - was probably the first to systematically voice its interests in the outcomes of foreign policy $^{3}$. During the second term of the Cardoso administration, for example, most editorials accused the government of not advancing a genuinely "national' interest in the negotiations of the FTAA and Mercosur. They also criticized the liberal stance of the government, which had failed to defend the interests of the country's industry at the WTO and had deepened Brazil's external dependency (VIEIRA DE JESUS, 2009). As a matter of fact, out of the 63 editorials published by Folha on foreign policy issues between 1999 and 2002, half of them (32) contained some degree of outright criticism, whereas only $5(7.9 \%)$ were openly favorable to the government's diplomacy ${ }^{4}$.

\footnotetext{
2 Rio de Janeiro's most popular daily, $O$ Globo, has frequently ranked in second among the most circulated newspapers. Although we have collected many of its editorials and op-eds, due to the lack of a digital database or an accurate search engine, data was not as robust as for the other newspapers. That is the only reason why we chose not to use $O$ Globo in this discussion, albeit acknowledging the importance of the newspaper and the eventual distortions such 'selection bias' may have caused.

${ }^{3}$ This is a movement that started in the late $1990 \mathrm{~s}$ and was consistent with the newspaper editorial policy and guidelines (Folha de São Paulo 1997).

${ }^{4}$ We adopted a straightforward categorical classification of the editorial content: positive, negative, and neutral. We classified as 'positive' articles that praised the government for a specific decision, or for the general guidelines of a given policy, throughout the entire text or its greater part. 'Negative' articles contained some degree of open criticism against the country's foreign policy or its basic formulators (the
} 
Folha's most prominent contender in the wealthy state of São Paulo, $O$ Estado de São Paulo, published 64 editorials on Cardoso's foreign policy in the same period (1999-2002). Although the proportion may look similar, the content goes in the opposite direction. No less than $26(40.6 \%)$ articles painted a flattering picture of the diplomatic service, whereas only $8(12.5 \%)$ were critical to the government. In both cases, the considerable number of neutral articles (26 for Folha and 34 for Estado) reflects a trend of reporting to the reader the economic and diplomatic challenges faced by the Cardoso administration, with no open ideological or political commitment.

This picture provides an interesting start to our argument. If it is correct to assume that Lula's foreign policy had utterly departed from his predecessor's - moving from a liberal-internationalist position to a nationalistglobalist one (SARAIVA, 2010) - then understanding the press behavior towards the new government's diplomacy as of 2003 would simply be a matter of inverting the signs. Folha would be less critical, and Estado would take up the opposition role. However, things did not turn out as expected: both periodicals have raised the voice against President Lula's foreign policy, as well as against the diplomatic service, the Foreign Minister, the outcomes of Brazil's strategies abroad, the relationship between the PT and foreign policy goals, and so forth ${ }^{5}$.

The triumph of Lula da Silva in 2002 has therefore led to a great deal of convergence in mass media content - against the recently elected government. It must be clear that we do not subscribe to what has been called by some journalists and bloggers the 'Coupist Press Party' (Partido da Imprensa Golpista, PIG), a label that overestimates, in an almost conspiratorial way, the ability of the mass media to coordinate their political and editorial interests. In any case, at least when it comes to foreign policy issues, one may notice a growing degree of similarity between what has been published in Folha and Estado - not just in their editorials, but also by their permanent and guest

President and/or the Foreign Service). 'Neutral' is understood here as a general comment on the challenges faced by the Foreign Ministry, be they at the level of the country's strategies and/or the global transformations, without a specific critical or complimentary tone.

5 Although it exceeds the scope of this article, it is important to mention that such 'wave of criticism' against the country's diplomacy also involved other mass media giants, such as $O$ Globo (daily newspaper based in Rio de Janeiro) and Veja (Brazil's most read weekly news magazine). 


\section{Guilherme Stolle Paixão e Casarões}

columnists. Many of the 'theses' advanced by the administration's opponents such as an excessive 'personalism' in foreign affairs, a retrograde third-worldism and anti-Americanism, or the unwanted presence of a 'special adviser' on foreign policy, Marco Aurélio Garcia - were replicated, or sometimes even created, by the newspapers.

A simple quantitative look at the editorials published between 2003 and $2010^{6}$, which corresponds to President Lula's both terms in office, reveals the critical trend in the relationship between the mass media and foreign policy. In comparison to the 63 articles that made reference to the diplomacy in late Cardoso years, Folha de São Paulo published 60 editorials on foreign policy throughout Lula's first term, and 70 during the President's last four years in office. As seen in Table 1, variation is slight, be it within a presidential term or between terms. Over the entire Lula administration, the newspaper dealt with diplomatic issues roughly on a three-week basis (an average of 16.25 editorials per year). The average is practically the same of the 1999-2002 period (15.75/year). If we consider that the occurrence of foreign policy issues in editorials was barely negligible in the previous years, the figures shown are meaningful; on the other hand, they suggest that Folha had no special interest in Lula's diplomacy - at least no more than immediately before.

Data on editorials brought out by OESP displays a different trend. Between 1999 and 2002, the daily had published 64 articles on diplomatic affairs. This number rose sharply to 160 (a growth of 250\%) on Lula's first term, and reached 120 editorials in the 2007-2010 period. In 2003 alone, Estado issued 37 opinions, in contrast with 5 in 1999 (and, for that matter, 9 in 1995 Fernando Henrique Cardoso's first year in office). During Lula's presidency, such editorials were published three times a month (or 35 a year), more than twice as much as in the previous four years. Unlike its main rival, O Estado de São Paulo has demonstrated greater concern with Lula da Silva's foreign policy.

\footnotetext{
6 Using the basic search engines at the newspapers's websites (http://www.folha.uol.com.br and http://acervo.estadao.com.br), we have filtered all editorials according to the following criteria: (1) they must contain the words "diplomacia" or "Itamaraty"; (2) the must deal directly with aspects of Brazilian foreign policy, be them at the level of policymaking, international strategies, or both.
} 
Table 1 - Editorials on foreign policy published in FSP and OESP, 1999-2010

\begin{tabular}{|c|c|c|c|c|c|c|c|c|c|}
\hline & \multicolumn{4}{|c|}{ Folha de São Paulo } & \multicolumn{4}{|c|}{ O Estado de São Paulo } \\
\hline & & Negative & Neutral & Positive & Total & Negative & Neutral & Positive & Total \\
\hline \multirow{4}{*}{ 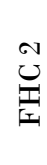 } & 1999 & 8 & 4 & 1 & 13 & 1 & 0 & 4 & 5 \\
\hline & 2000 & 10 & 6 & 0 & 16 & 2 & 3 & 8 & 13 \\
\hline & 2001 & 11 & 11 & 2 & 24 & 1 & 12 & 7 & 20 \\
\hline & 2002 & 3 & 6 & 1 & 10 & 6 & 13 & 7 & 26 \\
\hline \multirow{4}{*}{$\frac{\pi}{3}$} & 2003 & 4 & 6 & 6 & 16 & 15 & 18 & 4 & 37 \\
\hline & 2004 & 6 & 4 & 5 & 15 & 28 & 10 & 0 & 38 \\
\hline & 2005 & 11 & 4 & 1 & 16 & 28 & 10 & 1 & 39 \\
\hline & 2006 & 11 & 2 & 0 & 13 & 36 & 10 & 0 & 46 \\
\hline \multirow{4}{*}{$\frac{\pi}{3}$} & 2007 & 9 & 8 & 1 & 18 & 19 & 12 & 2 & 33 \\
\hline & 2008 & 9 & 5 & 4 & 18 & 7 & 12 & 0 & 19 \\
\hline & 2009 & 15 & 5 & 1 & 21 & 24 & 9 & 1 & 34 \\
\hline & 2010 & 8 & 5 & 0 & 13 & 25 & 8 & 1 & 34 \\
\hline
\end{tabular}

Source: http://folha.uol.com.br and http://acervo.estadao.com.br. Data compiled by the author.

These figures, however, are only part of the story. We must qualify the content of these editorials in order to have a more specific picture of how diplomacy was portrayed by the mass media in the Lula years. As already suggested, commentaries were mostly derogatory towards the government. The general impression is confirmed by a closer look at what was written and published. Out of the 60 articles issued by FSP between 2003 and 2006, at least 32 were explicitly critical of Lula's diplomacy $(53.3 \%)$, whereas only 12 praised the President or his foreign service $(20 \%)$. The case of Estado against the administration was even harsher: while 107 of the 160 editorials $(66.9 \%)$ were unfavorable towards foreign policy, an unimpressive five positive comments (3.1\%) were issued throughout Lula's first term.

The picture did not change much when it came to the President's second term. In a total of 70 editorials, Folha attacked the Foreign Service or its decisions in 41 of them $(58.5 \%)$. The number of articles with complimentary remarks was even smaller than in the previous years, totaling only six $(8.6 \%)$. The historical series of the newspaper's behavior in shown in Figure 1. 


\section{Guilherme Stolle Paixão e Casarões}

Figure 1 - Number of editorials (by content) published by Folha de São Paulo, 1999-2010

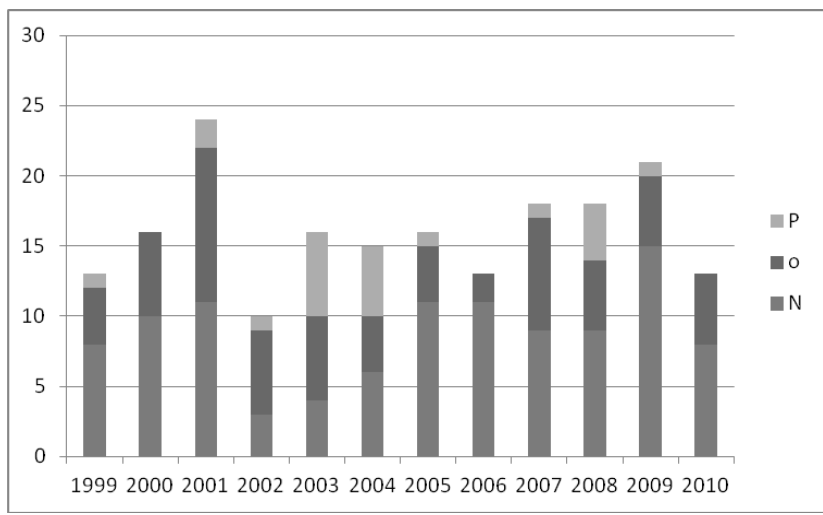

$\mathrm{P}=$ positive; $\mathrm{o}=$ neutral; $\mathrm{N}=$ negative. Data available at $\underline{\mathrm{http}}$ //folha.uol.com.br and compiled by the author.

In the case of Estadão, the trend followed suit - out of 120 commentaries published by the newspaper, 75 were dedicated to crucifying the country's foreign policy $(62.5 \%)$ whereas only four were (moderately) laudatory $(3.3 \%)$. The aggregate results are shown in Figure 2.

\section{Figure 2 - Number of editorials (by content) published by $O$ Estado de São} Paulo, 1999-2010

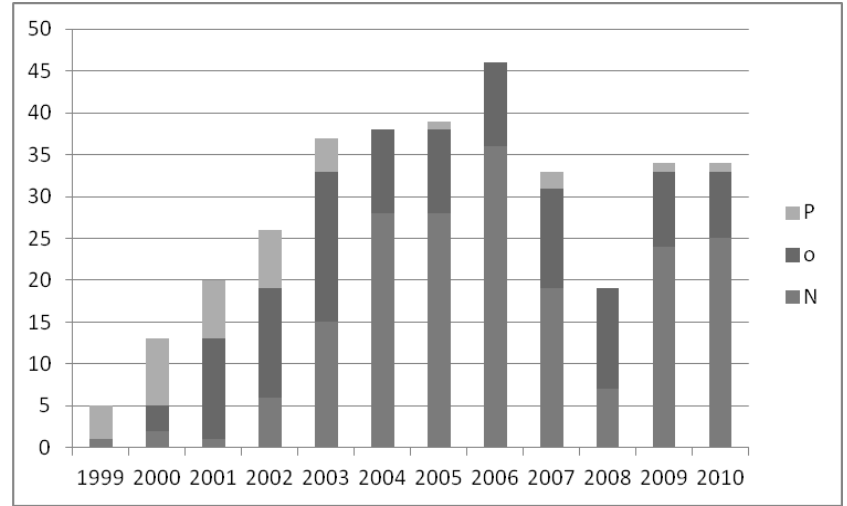

$\mathrm{P}=$ positive; $\mathrm{o}=$ neutral; $\mathrm{N}=$ negative. Data available at http://acervo.estadao.com.br and compiled by the author. 


\section{Assessing the content of editorials: what did the newspapers say?}

Did the newspapers agree on positive and negative aspects of Lula's foreign policy? To answer this, we must turn to the thematic content of the editorials so as to identify to what extent did opinions converge on the many topics of foreign policy. Many themes were recurring in the Lula da Silva years, such as trade diplomacy at the WTO or regional integration. The relationship between Brazil and Latin America's leftist leaders, such as Hugo Chávez, Fidel Castro, and Evo Morales, was particularly controversial. On most of them, the newspapers converged substantially, if not perfectly. We decided, however, to choose two major topics that were salient in the media and encompass some of the key foreign policy issues of that time: (1) the negotiations of the FTAA and Brazil-US bilateral relations (North-South axis); (2) South-South cooperation with China, Africa and the Middle East. They are meaningful because they allow us to compare a situation in which the press agreed with one in which opinions differed.

\section{(1) FTAA and Brazil-U.S. relations}

The FTAA appeared quite often in commentaries over the first couple of years of the Lula administration. This has to do with the importance negotiations on hemispheric integration assumed for Brazil in the early 2000s. Folha has given an overall positive judgment to the Brazilian posture at the negotiation table with the US, inasmuch as the Foreign Ministry did not surrender to the pressure for an unfavorable agreement. "It is obvious that Itamaraty should not mistake firmness for intransigence, but should not accept that the negotiation becomes a synonym for subservience, either. In general lines, Brazilian policy has been correct. So far, change does not seem necessary" (A Alca que interessa, October 15, 2003). The newspaper expresses a favorable stance to the existence of the free trade zone, as long as it did not put the interests of the country's economic sectors at risk. That would only be possible if Brazil should use its political clout and regional leadership to counterweight the American interests. "The US wants to implement the Free Trade Area of the Americas already in 2005, and an FTAA arrangement that did not include Brazil would be less than half FTAA. More than that, Lula is also a leader in South America" (Lula e Bush, June 21, 2003). 


\section{Guilherme Stolle Paixão e Casarões}

Estado, on the other hand, condemns the nation's diplomacy stance towards the FTAA. It affirms that the free trade area is undeniably good for Brazilian trade, and shows surprise with the positions adopted by Itamaraty. "The failure of the FTAA (...) is not in Brazil's interests (...). But the top decisionmakers of national diplomacy seem committed to bring down hemispheric negotiations" (É preciso trabalhar pela Alca, October 1st, 2003). The risk of isolation, according to the editors, would be the loss of economic dynamism and competitiveness, especially against aggressive markets such as China. The diplomatic mistake of rejecting the FTAA, the newspaper goes, is rooted in a purely ideological calculus, which may be attributed both to the President's Special Advisor to International Affairs, Marco Aurélio Garcia, and to the Secretary General of Itamaraty, ambassador Samuel Pinheiro Guimarães. "With such strategy, it is evident that Brazilian exports, albeit on the rise, will grow much less than they could. There are those who consider such policy a proof of patriotism" (Uma nova estratégia para a Alca, February 10, 2004).

Many of the editorials build their criticism on the lost opportunities in trade with the United States. Regarding this point, Folha de São Paulo is less critical: it subscribes to the Foreign Ministry's decision to resist against agreements that could hamper Brazilian trade and welcomes the positive bilateral relations with the Bush government: "Indeed, [State Secretary Condoleezza] Rice's trip [to Brazil] (...) does not seem to confirm current interpretations that the Brazilian diplomacy follows a line of distancing from the United States. Despite trade misgivings, disputes over the FTAA, the opposition against the War in Iraq and the anti-American leaning of some sectors within Itamaraty, Lula's Brazil has played in the region the role the U.S. expects" (A parceria Brasil-EUA, April 28, 2005). Folha, however, was very cautious in times when Brasilia decided to confront Washington in sensitive issues as biofuels or trade disputes. Negotiation, not retaliation, was the best strategy against the world's greatest economic power ( $\dot{A}$ mesa com os $\boldsymbol{E} U \boldsymbol{A}$, April 7, 2010).

As regards Brazil-U.S. relations, we may notice the different standing of both dailies. OESP attacks Lula's administration on the grounds that confronting the United States only benefits "those Brazilians who think that 
the country's self-respect may be assured by childish and counterproductive bravados" (A retórica da reciprocidade, January 9, 2004). Furthermore, many of Brazil's diplomatic decisions were understood as an anti-Americanist turn, from the exclusion of the eliminatory character of the English language in the Admission Exam to the Rio Branco Institute ( $O$ fator 'senso de ridículo', January 13,2005$)$ to the relationship with developing and emerging countries: "[i]n a globalized world, politically and militarily unipolar, and marked by United States and European economic, technological and trade superiority, foreign policy goes fifty years back in time, in the attempt of forging a SouthSouth axis that is not attractive to anyone except for the nostalgic thirdworldists of General Geisel" (Política feita de equívocos, May 4, 2005). Rejecting the FTAA was, according to an editorial published in late 2010, one of the greatest diplomatic follies of Lula's diplomacy, a folly about which Foreign Minister Amorim would often boast (A Alca e os complexados, September 14, 2010).

\section{(2) South-South cooperation}

While the debacle of the FTAA had meant a handful of lost opportunities to Brazil, the alternative found in South-South trade had been essentially fruitless. The recognition of China as a 'market economy' had, for instance, undermined the competitiveness of the Brazilian industry. The government's decision was grouched by business leaders, mostly at the Federation of Industries of São Paulo (FIESP), and has resonated negatively in both newspapers. Folha points out the irony behind the government recognizing the People's Republic but not giving a word about the repression associated with the communist regime: "as for Itamaraty, that does not lose a chance to delay the signature of free trade agreements with Western powers, always on behalf of the 'self-assurance' before the wealthier, it is curious that it does not give any sign with reference to the Chinese dictatorship and to the trade distortions sponsored by it" (Concessão à China, November 16, 2004). In the view of Estado, the worst part of the proximity with Beijing is that it had no counterpart whatsoever, representing a flunked attempt at the outset: "There is no strategy. There is just confusion and illusion. The priorities chosen by the Brazilian diplomacy lead to nowhere, because no other emerging power is interested in the politico-ideological fantasies that guide Itamaraty (Cortesãos e Mascates, November 28, 2004). 


\section{Guilherme Stolle Paixão e Casarões}

The relationship with Africa and the Middle East was also severely condemned as part of the grand design of Brazilian foreign policy. Although Folha points out that there might had been a positive aspect behind Lula's official visits to African countries, especially at the symbolic level, the technical aspects of bilateral negotiations were simply ignored, as in the case of the mistakes made in the president's trip to Nigeria, "which were laughable" (Frustração na África, April 13, 2005). The most worrisome aspect of Brazil's Africa policy, however, was the complete and utter disdain for human rights in the relationship with long-standing dictators. Abstaining against human rights violations in Darfur was, in the view of Folha's editors, a careless move driven by the 'obsession' for a permanent seat in the Security Council, as one editorial argues: "in search of support, Brazil has cast some of the most shameful votes in the history of its diplomacy" (Diplomacia e ditadura, October 17, 2007). To OESP, Brazil's new move towards Africa was purely ideological and part of an attempt of third-worldist indoctrination within the Foreign Service. "The distance between political-economic fiction that lulls the dreams of the president and real life was, throughout his trip [to five African nations], a worrisome and surely embarrassing issue" (As fantasias africanas de Lula, November 9, 2003). The relationship with autocracies was also shameful, according to the newspaper, as in the case of Lula's visit to Burkina Faso: "It is dispiriting to see President Lula putting his great personal prestige and the affection of the Africans for Brazil at the service of that miserable country's dictator" (Legitimando um ditador, October 17, 2007).

It was in Brazil's relations with Middle-Eastern countries, nonetheless, that the Lula administration has received its fiercest criticism - but also some moderate praise. Folha, on its part, has signaled towards a positive engagement of Brazil's diplomacy with regional issues after the official visits paid by the presidents of Israel, Iran, and the Palestinian Authority to Brasilia in late 2009. In this sense, Brazil should be able to share the example of its multicultural society abroad. "It starts with the example of pacific coexistence between citizens of the most diverse ethnic origins and religious beliefs - and of the rejection of interventionism - that Brazil may exert influence, albeit moderate, in the bloody chessboard of the Middle East" (Recepção equilibrada, November 25, 2009). But since Lula's first years in office the newspaper had shown some 
caution when it came to Middle Eastern affairs. On the relationship with Syria, for example, Folha warned that "there are no historical, political or commercial bonds between the governments of Lula and Assad (...). The widespread sensation is that Itamaraty has turned an anti-American obduracy into its main political guideline" (Brasil erra com a Síria, March 5, 2005). Finally, the Iranian conundrum - that has led to a fuel swap deal brokered by Brazil and Turkey in May 2010 - has also received a great deal of attention. The agreement was, according to the newspaper, "a controversial and frightful initiative" (A outra questão iraniana, June 16, 2010), and the friendship between Lula and the president of Iran, Mahmud Ahmadinejad, was excessively ideological. "By courting autocrats such as Ahmadinejad (...), president Lula has set the tone, which was seconded by Amorim, Garcia and other aides, of a foreign policy marked by clash. It is about time to change the score, the conductor, and its soloists" (Em outro tom, November 13, 2010).

The Brazilian position on human rights violations perpetrated by the Iranian regime have led Estado to dismiss Lula's foreign policy in the Middle East. "It is an intellectually poor - and morally thin - reasoning with which Foreign Minister Celso Amorim attempted to justify Brazil's abstention on the international draft resolution that condemned Iran for "recurring human rights violations' (...). There are no mitigating factors for the complicity with barbarism (Cúmplices da barbárie, November 24, 2010). In a passage that summarizes the main impressions OESP had of President Lula's diplomacy, Brasilia's decision to engage Middle Eastern issues is portrayed as a mixture of amateurism, nationalism, illusions of grandeur: "President Lula and Itamaraty (...) felt free to decide to solve problems on the other side of the world, and precisely the ones that, for years or decades, have made great powers lose their sleep, incapable as they were to promote peace in such regions. The intromission in the Israeli-Palestinian case was just pathetic. The involvement with Iran, on its part, is dangerous for it affects key issues of international security which Brazil is not ready to face" (Os erros da política externa, June 12, 2010).

Two considerations follow from this discussion. First of all, the newspapers shared the impression that Lula's foreign policy suffered from a number of problems, such as the president's excessive voluntarism, the sheer pragmatism in the relationship with the 'global South' (contrasted with the ideological partnerships in Latin America), and the unwanted influence of a 


\section{Guilherme Stolle Paixão e Casarões}

non-diplomat, Marco Aurélio Garcia, in foreign affairs. OESP has gone so far as to say it was a 'four-headed diplomacy', conducted by a powerless foreign minister, his ideological secretary-general Guimarães, and also by Garcia, an amateurish presidential aide, and José Dirceu, the most powerful minister during Lula's first term and a close friend of Fidel Castro (Diplomacia quadricéfala, April 27, 2005). As a result, Folha's editors point out, that administration's diplomacy was marked by a lack of coherence that increased over time: "the level of tunelessness of Lula's foreign policy (...) inspires caution and explanation" (Ruídos diplomáticos, July 3, 2009).

Secondly, but no less important, Folha and Estado may have criticized the government for different reasons - even when the target was the same. FSP rejected the means, but not necessarily the ends of foreign policy: "If the goals are correct, the same cannot be said of the means to achieve them during the Lula period. Our foreign policy has lost virtue to the extent it was used to minimize the frustration of the domestic party militancy, a mistake worsened by the stupid Manichaeism that so often prevailed in the decisions of the president and his aides" (Política externa, October 1st, 2010). OESP, on the other hand, dismissed both with equal harshness, as can be seen in the following passage: "when it comes to foreign policy, competence and realism were substituted by the 'parade diplomacy', moved by a half-baked third-worldism and by the president's personal ambition. The government despised opportunities of trade agreements with the most developed markets and gave priority to a delirious South-South policy" (Ganhos e perdas da era Lula, December 30, 2010).

\section{Final remarks}

Lula's administration has changed foreign policy in many ways. First, it has taken Brazil's global recognition to a whole different level, as the nation's voice could finally be heard in multilateral negotiations, international conflicts, financial institutions, and bilateral contacts with credibility and assertiveness. Second, it has restored the open developmentalist strategy that has marked Brazilian foreign policy in the second half of the twentieth century. Third, as stated in foreign minister Celso Amorim's inauguration speech back in 2003, it 
has contributed to involving 'the society as a whole' in foreign affairs, making the country's global agenda particularly salient among domestic actors.

But raising the profile of the country abroad has come with a price. If the achievements of diplomacy under Lula da Silva have received a great deal of attention, the same can be said of its blunders. However subjective this judgment may be, the president and his foreign service have been condemned for what they have done, from Haiti to Honduras, from Iran to Venezuela, from the FTAA to Mercosur. The analysis of the how the mass media commented on the Brazilian foreign policy in recent years has provided, in this sense, a robust example of how the press behaved towards the Lula administration at large. Despite the differences shown in the coverage offered by both newspapers, we may notice that OESP and FSP alike were extremely critical of the government. Still, the underlying reasons may not have been the same. While Folha has condemned foreign policy at an almost personal level, blaming the president and his aides for any misconducts but commending some of its goals, Estado completely diverged from Lula's diplomacy in its worldviews, actors, and methods.

The pluralization of actors with a stake in foreign affairs has allowed for the mass media to bring diplomacy to the top of their agenda. Presidentialization, on its part, has taken foreign policy to the political battlefield, for good and bad. Whereas this may seem a liability for a charismatic president, judging by the number and depth of attacks Lula has received, it may also be an important asset. After all, popular approval of foreign policy has followed the president's huge popularity, which has ultimately undermined any attempts of newspapers to set the foreign policy agenda. This, however, is a discussion for works to come.

\section{REFERENCES}

ALMEIDA, Paulo Roberto de. "Uma política externa engajada: a diplomacia do governo Lula". Revista Brasileira de Política Internacional, vol. 47, no. 1, 2004 . 


\section{Guilherme Stolle Paixão e Casarões}

. “Uma nova 'arquitetura' diplomática? Interpretações divergentes sobre a política externa do governo Lula (2003-2006)". Revista Brasileira de Política Internacional, vol. 49, no. 1, 2005.

AMORIM, Celso. "Discurso por ocasião da transmissão do cargo de ministro de Estado das Relações Exteriores". In: Discursos, Palestras e Artigos do Chanceler Celso Amorim: 2003-2010. Brasília: Ministério das Relações Exteriores, 2011a.

BARROS, Alexandre de S. C. "A formulação e implementação da Política Externa Brasileira: o Itamaraty e os novos atores". In: Muñoz, Heraldo e Tulchin, Joseph (eds.). América Latina e a Política Mundial. São Paulo: Convívio, 1986.

BOITO Jr., Armando. “A Hegemonia Neoliberal no Governo Lula”. Crítica Marxista, no. 17, 2003.

CARVALHO, Maria Izabel Valladão de. "Condicionantes internacionais e domésticos: o Brasil e o G-20 nas negociações agrícolas da Rodada Doha". Dados, vol. 53, no. $2,2010$.

CASARÕES, Guilherme. "O papel do Itamaraty na definição da política externa de Collor de Mello". Revista Brasileira de Política Internacional, vol. 55, no. 1, 2012 .

CASON, Jeffrey; POWER, Timothy. "Presidentialization, pluralization, and the rollback of Itamaraty: explaining change in Brazilian Foreign Policy making in the Cardoso-Lula Era". International Political Science Review, vol. 30, no. 2,2009 .

CASTELAN, Daniel. “A implementação do consenso: Itamaraty, Ministério da Fazenda e a Liberalização Brasileira". Contexto Internacional, vol. 32, no. 2, 2010.

CERvo, Amado e BUENO, Clodoaldo. História da Política Exterior do Brasil. 2a . ed. Brasília: Ed. UnB, 2002.

CHEIBUB, Zairo. "Diplomacia e Construção Institucional: o Itamaraty em perspectiva histórica". Dados, vol. 28, no. 1, 1985.

COUTO, Cláudio G.; BAIA, Paulo F. "O governo Lula: uma avaliação política e econômica". In: Sallum Jr., Brasilio (ed.). Brasil e Argentina hoje: política e economia. Bauru: EDUSC, 2004.

DANESE, Sérgio França. Diplomacia Presidencial: história e crítica. Rio de Janeiro: Topbooks, 1999.

FARIA, Carlos Aurélio Pimenta de. "Opinião pública e política externa: insulamento, politização e reforma na produção da política exterior do Brasil". Revista Brasileira de Política Internacional, vol. 51, no. 2, 2008.

FERREIRA, Tulio. O Universalismo e seus descontentes. Curitiba: Juruá, 2009.

FLEMES, Daniel. "O Brasil na iniciativa BRIC: soft balancing numa ordem global em mudança?". Revista Brasileira de Política Internacional, vol. 53, no. 1, 2010.

FONSECA JUNIOR, Gelson. Diplomacia e Academia. Brasília: FUNAG, 2011.

FORTES, Alexandre. "A política externa do governo Lula: algumas considerações". In: Freixo, Adriano de et al. (orgs.). A política externa brasileira na Era Lula. Rio de Janeiro: Apicuri, 2011. 
FRAnco, Geisa Cunha. Opinião Pública e Política Externa na Abertura Democrática. Curitiba: Juruá, 2009.

HADDAD, Tathiana. "Diplomacia Pública: a Política Externa Brasileira e as ONGs na Conferência de Beijing". Dissertação de Mestrado. Rio de Janeiro: PUC-Rio, 1995.

HIRST, Monica; LIMA, Maria Regina Soares de; PINHEIRO, Leticia. "A política externa brasileira em tempos de novos horizontes e desafios". Nueva Sociedad especial em português, 2010.

HURRELL, Andrew. "Lula's Brazil: a rising power, but going where?". Current History, February 2008.

KIngstone, Peter. Crafting Coalitions for Reform. University Park: The Pennsylvania State University Press, 1999.

LAFER, Celso. A identidade internacional do Brasil e a política externa brasileira. São Paulo: Perspectiva, 2001.

LAGO, André. Estocolmo, Rio, Johanesburgo: o Brasil e as três Conferências Ambientais das Nações Unidas. Brasília: Fundação Alexandre de Gusmão, 2006.

LESSA, Mônica e GAVIÃO, Leandro. "Política externa, mídia e propaganda nos governos Lula da Silva (2003-2010)". In: Freixo, Adriano de et al. (orgs.). A política externa brasileira na Era Lula. Rio de Janeiro: Apicuri, 2011.

LIMA, Maria Regina Soares de. "Ejes Analíticos y Conflicto de Paradigmas en la Política Exterior Brasileña”. America Latina/Internacional, vol. 1, no. 2, 1994.

. “Instituições Democráticas e Política Exterior". Contexto Internacional, vol. 22 , no. 2,2000 .

LIMA, Maria Regina Soares de; HIRST, Mônica. "Brazil as an intermediate state and regional power: action, choice and responsibilities". International Affairs, vol. 82, no. 1, 2006.

MALAMUD, Andrés. "Presidential diplomacy and the institutional underpinnings of Mercosur: an empirical examination". Latin American Research Review, vol. 40 , no. $1,2005$.

. "A Leader without Followers? The growing divergence between the regional and global performance of Brazilian foreign policy". Latin American Politics and Society, vol. 53, no. 3, 2011.

MANCUSO, Wagner Pralon; OLIVEIRA, Amâncio Jorge de. "Abertura econômica, empresariado e política: os planos doméstico e internacional". Lua Nova, vol. $69,2006$.

MANZUR, Tânia. "Opinião Pública e Política Externa do Brasil do Império a João Goulart: um balanço historiográfico". Revista Brasileira de Política Internacional, vol. 42, no.1, 1999.

. Opinião Pública e Política Exterior do Brasil. Curitiba: Juruá, 2009.

OLIVEIRA, Amancio Jorge de; ONUKI, Janina. "Eleições, Partidos Políticos e Política Externa no Brasil". Revista Politica Hoje, vol. 19, no. 1, 2010. 


\section{Guilherme Stolle Paixão e Casarões}

OLIVEIRA, Amancio Jorge de; ONUKI, Janina; OLIVEIRA, Emmanuel de. “Coalizões Sul-Sul e Multilateralismo: Índia, Brasil e África do Sul”. Contexto Internacional, vol. 28, no. 2, 2006.

PECEQUILO, Cristina Soreanu. "A New Strategic Dialogue: Brazil-US relations in Lula's presidency (2003-2010)". Revista Brasileira de Política Internacional, vol. 53, special edition, 2010.

PINHEIRO, Leticia. "Traídos pelo desejo: um ensaio sobre a teoria e a prática da política externa brasileira contemporânea". Contexto Internacional, vol. 22, no. $2,2000$.

RICUPERO, Rubens. “O que restou do consenso de Tancredo?". Folha de São Paulo, 30 de dezembro de 2001.

"À Sombra de Charles de Gaulle: uma diplomacia carismática e intransferível". Novos Estudos, vol. 87, 2010.

SARAIVA, José Flávio Sombra. "A África e a política externa na era Lula: relançamento da política atlântica brasileira". In: Freixo, Adriano de et al. (orgs.). A política externa brasileira na Era Lula. Rio de Janeiro: Apicuri, 2011.

SARAIVA, Miriam Gomes. "A diplomacia brasileira e as visões sobre a inserção externa do Brasil: institucionalistas pragmáticos $\mathrm{x}$ autonomistas". Mural Internacional, ano 1, no. 1, 2010.

VEIGA, João Paulo Cândia. "As negociações comerciais no governo Lula”. Revista Brasileira de Comércio Exterior, 2005.

VIEIRA, Marco Antonio; Alden, Chris. "India, Brazil, and South Africa (IBSA): SouthSouth cooperation and the paradox of regional leadership". Global Governance, vol. 17, 2011.

VIEIRA DE JESUS, Diego Santos. "Mídia e política externa: democratização ou instrumentalização? A política externa brasileira segundo a Folha de São Paulo (1998-2002)". Política Externa, vol. 18, no. 3, 2009.

VIGEVANI, Tullo; CEPALUNI, Gabriel. "Lula's foreign policy and the quest for autonomy through diversification". Third World Quarterly, vol. 28, no. 1, 2007.

VIGEVAnI, Tullo; MARIAno, Marcelo. A Alca e a política externa brasileira. São Paulo: CEDEC, 2005.

VIGEVANI, Tullo; OLIVEIRA, Marcelo Fernandes de; CINTRA, Rodrigo. "Política Externa no Governo FHC: a busca da autonomia pela integração". Tempo Social, vol. 15, no. 2, 2003.

VISENTINI, Paulo Fagundes. "Brazil's Contemporary Foreign Policy: an affirmative agenda". In: Hofmeister, William (ed.). G20: perceptions and perspectives for global governance. Singapore: Konrad Adenauer Stiftung, 2011.

. "O G-3 e o G-20: o Brasil e as novas coalizões internacionais". In: Oliveira, Henrique Altemani de; Lessa, Antônio Carlos. Relações Internacionais do

Brasil: temas e agendas. Vol. 2. São Paulo: Saraiva, 2006. 


\begin{abstract}
This article looks at this new relationship, in the light of two concurrent trends: the pluralization of actors with stakes in foreign policy; and an active presidential diplomacy (CASON AND POWER 2009). We argue that, more than just a battlefield of ideas, Brazil's most prominent media vehicles have played an active role against Lula's foreign policy, although they had but a limited agenda-setting capacity. To this end, the text will be divided in four sections. The first one deals with the recent developments of foreign policymaking in Brazil, and seeks to understand how the introduction of new actors and institutions has affected the political balance behind the country's external relations. The second provides an overview of Lula's foreign policy strategies and their relationship with presidential diplomacy. The third offers some data on the behavior of two selected newspapers, Folha de São Paulo (FSP) and $O$ Estado de São Paulo (OESP), on foreign policy issues. The third and final section compares media reactions to Brazil's relations with the United States, most specifically regarding negotiations on the Free Trade Area of the Americas (FTAA), and to some aspects of Brazilian South-South cooperation, and discusses the most relevant results.
\end{abstract}

\title{
KEYWORDS
}

Lula; Media; Brazilian Foreign Policy; 


\section{DEVELOPING FROM THE SOUTH: SOUTH-SOUTH COOPERATION IN THE GLOBAL DEVELOPMENT GAME}

\section{Sean Burges ${ }^{1}$}

The international development assistance scene is getting busier. Traditionally, the lines of division have been pretty clear, with industrialized countries of the Organization for Economic Cooperation and Development providing development assistance to the rest of the world. By 2010, members of the OECD's Development Assistance Committee (DAC) were spending US\$128.5 billion a year on official development assistance (ODA) to social and economic progress in the South. To ensure efficient use of funds the DAC membership was also organizing and thinking of enforcing codes of conduct in an attempt to ensure that aid is effective, using a succession of High Level Forums to get input and buy-in from developing countries. The end result has effectively been the rise of a self-appointed club of countries who have tried to decide how, when and where development assistance should be dispensed.

Today, it appears that the authority of this club of developed, aidproviding nations is under attack, not least by articulate and charismatic figures such as Dambisa Moyo (2009). The real challenge comes from countries variously described as emerging donors, new development partners, and new donors. Irrespective of the name, the goal is to use South-South technical cooperation for developmental goals. China is the most discussed non-DAC source of development cooperation, but other increasingly active countries

${ }^{1}$ PhD (Warwick) in Politics and International Studies; MA (Western Ontario) in Political Science. Lecturer in International Relations in the Australian National University. (sean.burges@anu.edu.au) 
include Brazil and India as major players and Chile, the Gulf States, Indonesia, and South Africa as quietly rising voices. The challenge these countries present to the existing international aid architecture is that they operate outside of it and in a manner that is at times alien to officials within existing development agencies. While the new players are not necessarily antagonistic to the DAC, they see no reason to petition the DAC for membership or await Northern benediction of their South-South technical cooperation agenda.

The purpose of this paper is to give an initial sense of what Southernbased development cooperation is, how it is organized and delivered, and the logic behind the decision to engage in this sort of activity. Attention will be focused on a subset of the major countries engaged in providing South-South cooperation: Brazil, China, India and South Africa. Ultimately, the argument that will be presented is that these, for the DAC, newly discovered actors are not a threat if the focus is the delivery of effective official development assistance. Instead, they may offer solutions to some of the questions plaguing high-level policy discussions about policy coherence and aid effectiveness.

\section{What is South-South Cooperation?}

While members of the DAC continue to provide the bulk of global bilateral assistance measured in straight dollar terms, 'emerging donors' are becoming increasingly important through the provision of soft loans, technical assistance, foreign investment and increased market access. Although data is hard to find, some well-informed estimates have been released through the United Nations system. ECOSOC estimates that South-South development cooperation flows in 2006 were somewhere between US\$9.5 billion and US\$12.1 billion (ECOSOC, 2008). A 2011 'State of South-South Cooperation' report to the UN General Assembly provided updated numbers for 2008 with an estimated total spend of US $\$ 13.9$ billion, or just under one tenth of DAC expenditure. ${ }^{2}$

The relative disparity between Northern and Southern development cooperation expenditures is misleading and understates the impact of Southern expenditures for two sets of reasons. First, the internal economic stabilization

\footnotetext{
2 United Nations General Assembly, “Operational Activities for Development: South-South Cooperation for Development. The State of South-South Cooperation Report of the Secretary-General." A/66/229 (3 August 2011).
} 
and international emergence of Brazil, India and China - three of the Goldman Sachs 'BRIC' countries - has provoked a renaissance of the Southern solidarity approach to development captured in UNCTAD's 1978 Buenos Aires Plan of Action on South-South Cooperation. ${ }^{3}$ By its nature South-South technical cooperation offers the potential for a different kind of development return than traditional DAC assistance because it is based on the premise that "developing countries share knowledge, skills, expertise and resources to meet their development goals through concerted efforts" (UNITED NATIONS, 2012). The mindset is subtly, but critically different, starting from an assumption that development is a joint process, not something that one state can give to another. Projects thus take on a dialectical quality, with the country providing the assistance gaining experiences that can help with domestic development. Equally are the resultant person-to-person and institution-to-institution linkages that accelerate growth of the civil society, bureaucratic and business networks that drive growth in the North.

Most DAC member development agencies recognize that South-South cooperation offers major contributions to development results because it directly transfers knowledge and expertise that has been generated and successfully implemented within a developing country context, not formulated in an industrialized country and then trialed in a selected partner country. There is also a greater cross-cultural receptiveness to South-South cooperation because it is explicitly framed in terms of solidarity and operates largely free of an historical legacy of colonialism. Added to this is the lower cost-base of SouthSouth cooperation. On a bureaucratic level, the governance structures are much simpler, creating a more direct link between decision-makers and the success or failure of a program. Countries engaged in South-South cooperation use accounting rules that do not necessarily include items that the DAC classifies as ODA, i.e., first year refugee resettlement costs, bureaucratic contributions in kind from other government departments, or the layers of compliance staff necessary to satisfy $\mathrm{DAC}$ reporting requirements. ${ }^{4}$

3 United Nations Special Unit for South-South Cooperation, "Buenos Aires Plan of Action," (1978): http://ssc.undp.org/Buenos-Aires-Plan-of-Action.22.0.html.

${ }^{4}$ OECD-DAC (2008), “Is it ODA?" Fact Sheet: www.oecd.org/dataoecd/21/21/34086975.pdf. [Accessed 6 June 2012] 
The actual cost of delivering South-South technical cooperation can be significantly lower than a similar DAC-member program. Countries such as Brazil and China avoid contracting external consultants for their projects. Instead, internal governmental expertise is sent to the partner country to pursue the project. This not only reduces the cost of delivering programming by avoiding the higher costs of external consultants and NGOs, but also lowers overheads because it removes the need for the intricate tendering, accounting and monitoring systems. Savings are amplified by the lower salaries of emerging market government employees. Finally, the full expenditure necessary to pursue a South-South cooperation program may not be evident in the figures reported by the implementing agency because the technical experts sent to do the work may be paid by their home department, not the 'development' agency coordinating the project.

The second set of factors complicating a comparison development cooperation expenditure lies in the explicit elements of outward engagement found in many emerging market countries, with collective advancement being seen at least rhetorically as an important element of sustainable domestic growth (PREBISCH, 1988; SUNKEL; ZULETA, 1990). In the Brazilian case this was clearly annunciated as part of Lula's vision of a new international economic geography (SILVA, 2004). While less triumphalist in tone, the Chinese and Indian governments have been very active along the same lines, with some scholars pointing to a growing trend of moving production plant to Africa and developing at regional and inter-regional production chains (BRAUTIGAM, 2009). The result is a genuine recasting of global trade. SouthSouth trade has gone from being $10 \%$ of world trade thirty years ago to $20 \%$ today, exceeding an annual level of US $\$ 2$ trillion by 2007 (LAMY, 2012). This pattern is borne out in trade data in tables 1 and 2, which demonstrates a rapid acceleration in bilateral trade between key emerging market sources of SouthSouth technical cooperation and sub-Sahara Africa and developing Asia. 
Table 1: Exports to developing regions (US\$ millions)

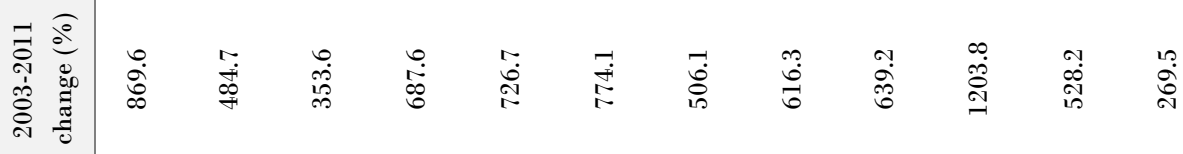

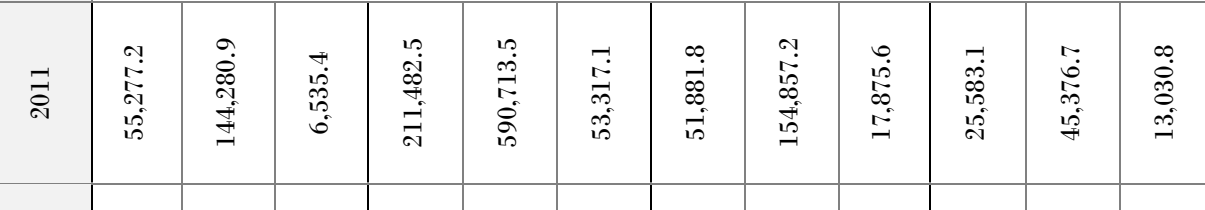

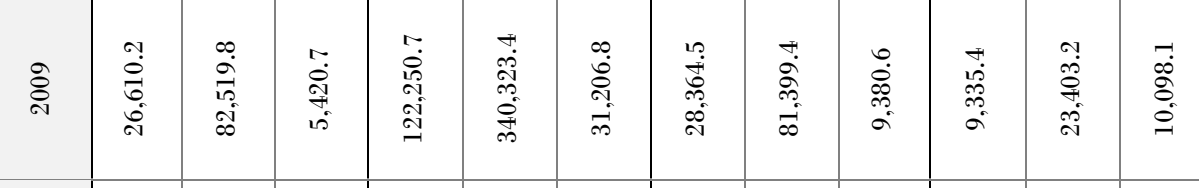

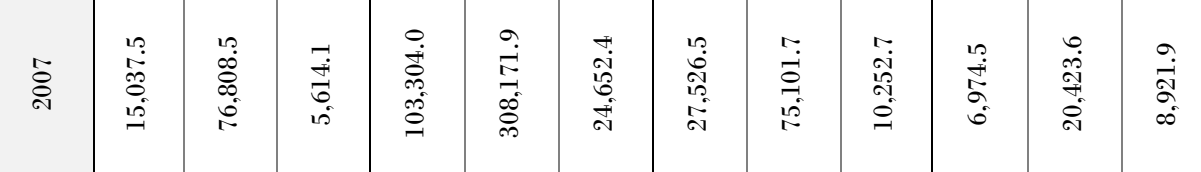

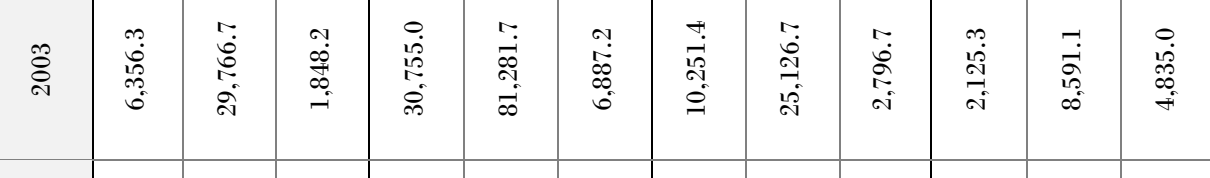

\begin{tabular}{|c|c|c|c|c|c|c|c|c|c|c|c|c|}
\hline 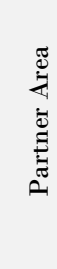 & 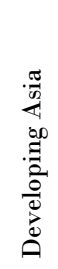 & 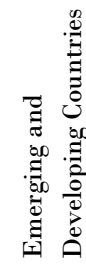 & 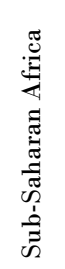 & 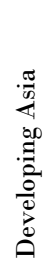 & 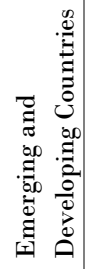 & 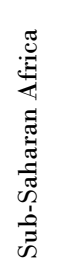 & 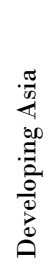 & 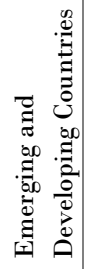 & 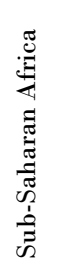 & 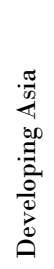 & 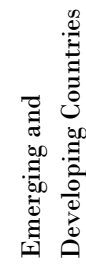 & 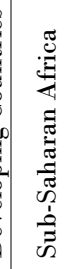 \\
\hline
\end{tabular}

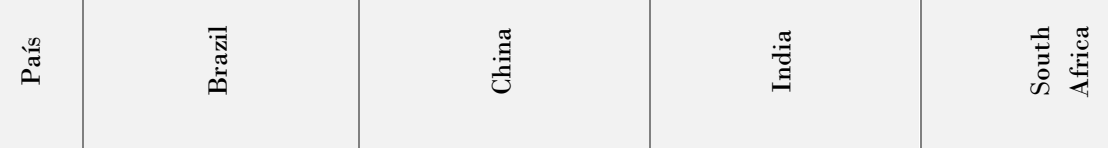


Table 2: Imports from developing areas (US\$ millions)

\begin{tabular}{|c|c|c|c|c|c|c|c|c|c|c|c|c|}
\hline 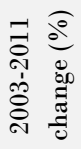 & $\begin{array}{l}10 \\
\ddot{10} \\
=1\end{array}$ & $\stackrel{\circ}{\frac{1}{6}}$ & $\begin{array}{l}0 \\
\stackrel{0}{0} \\
0 \\
10\end{array}$ & 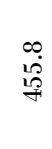 & $\begin{array}{l}\vec{A} \\
\stackrel{\text { Oे }}{0}\end{array}$ & r. & $\begin{array}{l}\dot{0} \\
\stackrel{\circ}{\circ}\end{array}$ & 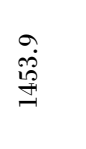 & $\begin{array}{l}\stackrel{1}{0} \\
\stackrel{\sigma}{=}\end{array}$ & $\begin{array}{l}\text { àd } \\
\text { Oे }\end{array}$ & 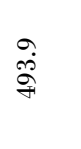 & 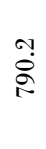 \\
\hline$\overline{\vec{\sim}}$ & 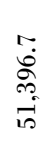 & 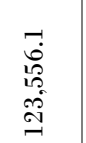 & $\begin{array}{l}\stackrel{\infty}{\stackrel{C}{C}} \\
= \\
=\end{array}$ & 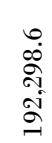 & $\begin{array}{l}\underset{+}{+} \\
\underset{1}{0} \\
10 \\
10 \\
10\end{array}$ & 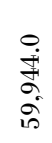 & 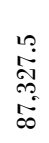 & 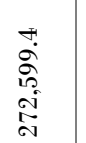 & $\begin{array}{l}0 \\
\stackrel{0}{0} \\
\ddot{8} \\
\text { i } \\
\text { ô }\end{array}$ & 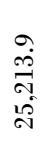 & 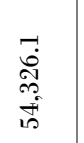 & $\begin{array}{l}\stackrel{+}{\circ} \\
\infty \\
\infty \\
\infty\end{array}$ \\
\hline ڤ્ڤે & $\begin{array}{l}\infty \\
\stackrel{0}{\sigma} \\
\stackrel{\sigma}{+} \\
\vec{\sigma}\end{array}$ & $\begin{array}{l}\infty \\
\stackrel{0}{0} \\
\overrightarrow{0} \\
\text { of } \\
\infty\end{array}$ & 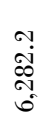 & $\begin{array}{c}\stackrel{0}{\dot{2}} \\
\stackrel{0}{1} \\
\stackrel{0}{0}\end{array}$ & 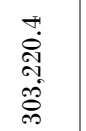 & 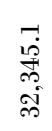 & 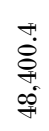 & 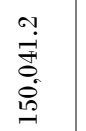 & 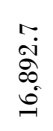 & 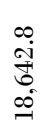 & 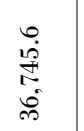 & $\begin{array}{l}\overrightarrow{+} \\
\stackrel{d}{0} \\
\text { if }\end{array}$ \\
\hline ڤ్ & & 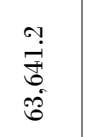 & $\frac{\pi}{\stackrel{7}{\circ}}$ & 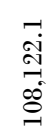 & 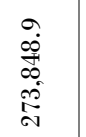 & 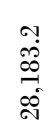 & $\begin{array}{l}0 \\
\stackrel{\circ}{\circ} \\
\text { م. }\end{array}$ & $\begin{array}{l}0 \\
\mathbb{N} \\
\stackrel{0}{0} \\
\mathbb{N} \\
0 \\
0\end{array}$ & 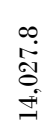 & 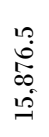 & 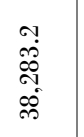 & $\begin{array}{l}-1 \\
\stackrel{1}{1} \\
00 \\
\text { if }\end{array}$ \\
\hline ڤి & $\begin{array}{l}\vec{\alpha} \\
\stackrel{\sigma}{\sigma} \\
\sigma\end{array}$ & 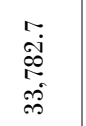 & 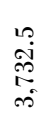 & 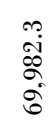 & $\begin{array}{l}0 \\
\stackrel{0}{0} \\
\stackrel{0}{0} \\
\stackrel{0}{-}\end{array}$ & $\begin{array}{l}0 \\
10 \\
10 \\
0 \\
0 \\
0\end{array}$ & $\begin{array}{l}\stackrel{0}{0} \\
\stackrel{0}{0} \\
\infty \\
0\end{array}$ & 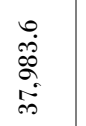 & 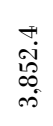 & $\begin{array}{l}\stackrel{0}{\leftrightarrows} \\
\stackrel{\Xi}{=} \\
\sigma\end{array}$ & 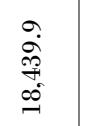 & \begin{tabular}{l}
$\infty$ \\
$\stackrel{\infty}{+}$ \\
\multirow{\lambda}{N}{} \\
on
\end{tabular} \\
\hline ڤ̊̊̆ & 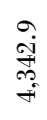 & 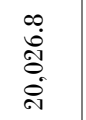 & $\begin{array}{l}0 \\
\stackrel{0}{0} \\
0 \\
0 \\
\text { i }\end{array}$ & 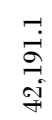 & $\begin{array}{l}\stackrel{0}{+} \\
\stackrel{+}{\text { a }} \\
\stackrel{+}{0}\end{array}$ & 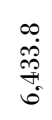 & $\begin{array}{l}\infty \\
\dot{\infty} \\
\vdots \\
0 \\
0\end{array}$ & $\begin{array}{l}\stackrel{10}{9} \\
\stackrel{9}{ \pm} \\
\stackrel{\infty}{\sim}\end{array}$ & 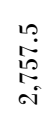 & $\begin{array}{l}\overrightarrow{+} \\
\stackrel{H}{\mathrm{H}} \\
\stackrel{+}{+}\end{array}$ & $\begin{array}{l}\text { r. } \\
\circ \\
\sigma \\
\sigma\end{array}$ & $\begin{array}{l}\stackrel{0}{\circ} \\
\stackrel{0}{\rightarrow} \\
=\end{array}$ \\
\hline 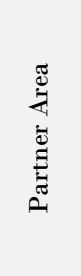 & 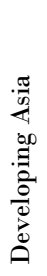 & 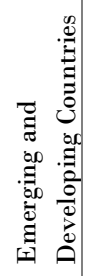 & 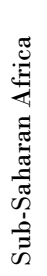 & $\begin{array}{l}\frac{\pi}{0} \\
\frac{0}{2} \\
00 \\
.00 \\
0 \\
0 \\
0 \\
0 \\
0\end{array}$ & 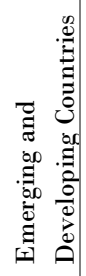 & 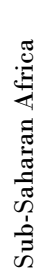 & 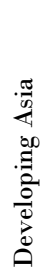 & 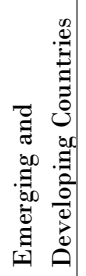 & 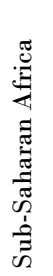 & $\begin{array}{l}. \frac{\pi}{0} \\
\frac{0}{2} \\
0 \\
.00 \\
0 \\
0 \\
0 \\
0 \\
0 \\
0 \\
0\end{array}$ & 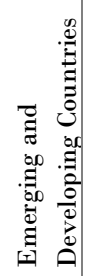 & 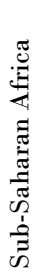 \\
\hline $\begin{array}{l}\vec{E} \\
\dot{\Xi}\end{array}$ & & \multicolumn{2}{|l|}{ 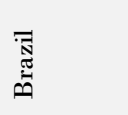 } & & \multicolumn{2}{|l|}{ తొ } & & \multicolumn{2}{|l|}{ 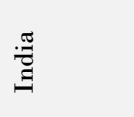 } & \multicolumn{3}{|c|}{ 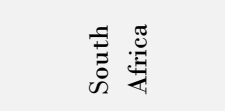 } \\
\hline
\end{tabular}

Source: IMF Direction of Trade Statistics. 


\section{Sean Burges}

In part this surge in trade is driven by Chinese and Indian need for commodities to sustain domestic growth and export-oriented economic activity. The other part of the story is that of new markets for the lower technological products that are produced not just by workers in the major emerging market economies, but also increasingly in developing countries. Globalized trade and investment flows are being used to drive internationally integrated industrial development strategies to bring about socio-economic transformation in major emerging markets.

The substance of growing Southern economic muscularity is also evident in the shifts in foreign direct investment flows necessary to create the global value-chains driving contemporary economic growth (MARKUSEN; VENABLES, 1999). This is evident in the number of Southern-based multinational corporations, leaping from 2,700 in 1993 to over 18,000 in 2005. These firms were in turn responsible for over US\$253 billion in Southoriginating FDI in 2007, of which 40\% was destined for other Southern countries (UNGA, 2009). For Northern observers the confusing aspect is the tendency to conflate rises in bilateral trade, FDI flows and EXIM financing operations with the provision of development assistance. In some respects this is not necessarily a problem, but instead points to something closer to a crossgovernment policy coherent approach to development. ${ }^{5}$

Part of these changes comes from a recasting of global production systems. In her work on China's role in Africa Deborah Bräutigam (2008) resurrects the Japanese 'flying geese' model of development seen in twentieth century Southeast Asia (AKAMATSU, 1962), which saw lower value-added industries being pushed from the major emerging market countries to other developing countries as cost-bases change. The rapidity of this can be seen today in the revivification of Mexican exports to the North American market as the rising cost of labour drives up the price of Chinese exports (SHARMA, 2012). Other research points to the 'creative destruction' of domestic industrial sectors in China and their relocation to parts of Sub-Saharan Africa (BLAISE, 2005). Similar events are taking place in Brazil, with foreign trade officials actively seeking to build links between São Paulo industrial elites and small-

\footnotetext{
5 For one way to understand this, see www.cgdev.org/section/initiatives/_active/cdi/
} 
scale textile mills in Bolivia. Maquiladora plants in Paraguay for the Brazilian and Argentine markets are appearing as regional infrastructure links thicken. ${ }^{6}$ As is highlighted in tables 1 and 2, the result is a surge in the imports and exports flowing between developing countries and the BRICS. While a substantial portion of the flows originating in the poorest countries takes the form of primary materials destined for surging emerging markets, there is a growing traffic in the labour intensive and semi-processed products.

This is creating a bit of confusion for analysts in Northern development agencies trying to discern where development assistance ends and investment begins. Many of the state-financed venture capital investments coming from countries such as Brazil, China and India appear risky to the point where Northern governments tend to view them as masked aid or attempts at economic domination. Little attention is given to the different risk profiles at play, Southern investors and institutions engaged in the outward expansion of emerging market economies generally demonstrating a much higher risk tolerance than their Northern counterparts. Viewed more cynically, we can argue that the new development partners are working with governance structures closer to 1920s North America than twenty-first century Europe. The general hypothesis is that capital in the South may now be more pioneering and adventurous than in the North, which is reinforced by state-based financing that allows firms to work with decennial profit horizons rather than Wall Street-driven quarterly targets.

\section{Patterns of South-South Cooperation}

Many of the leaders in South-South cooperation are not "new" actors in international development. Most have been providing development assistance for decades (ie. China, India, Saudi Arabia), but do not participate in multilateral fora for 'established' donors, such as the OECD 's Development Assistance Committee (DAC), the OECD's Export Credits Group or the Paris Club of creditor countries (MANNING, 2006). The barrier here is a perception of clubiness to the OECD, which exerts a strange pattern of attraction and revulsion. Some countries such as Chile and Mexico have been more than happy

6 "Investindo no Paraguai," editorial, O Estado de São Paulo (1 February 2011). 
to join, but others such as Brazil, China and India only feel a need to converse with a grouping where they would have little influence.

Despite the institutional independence of the new development actors, some follow a model close to that seen in DAC-member agencies. Generally this maps onto the available budget size, with the financially smaller programs focusing most on 'softer' development programming of capacity building projects and technical training. This is not to say that the larger players do not engage in such activities. In 2011 India announced an extra US\$700 million for additional African training programs and institutes. ${ }^{7}$ China has massive capacity building programs, training over 10,000 Africans between 2006 and 2009 as a part of a scholarship system that offers 4,000 study places a year. The additional assistance that the larger countries offer comes in the form of infrastructure projects, albeit sometimes for public works like sports stadium that are more symbolism than human development.

The substance of the concern from the North is that South-South cooperation, especially from China and India, is excessively focused on access to natural resources (SANBORN; TORRES, 2009). A lack of conditionality on resource-backed infrastructure loans is held up as a major concern because it could not only undercut the global aid effectiveness agenda, but also create a situation where sub-Saharan countries are saddled with new debts just in addition to existing obligations. At issue is a conflation of perceived foreign aid and emerging market commercial activity. Again, the case of China is instructive. The maligned infrastructure funding for resource access are often presented in the media and policy commentary as a straight resource grab by China. Yet, the reality is that this approach differs little in substantive terms from previous loan agreements from OECD countries guaranteed by resource rents.

What matters are the terms of the infrastructure for resource contracts. Are resources-based repayments valued at market rates or a pre-negotiated price? Is local or imported labour used for infrastructure construction? For China this increasingly appears to be an issue in Africa, with many countries

\footnotetext{
7 "India announces $\$ 5$ billion aid for Africa, seeks support for UN reforms," (24 May 2011):
} biz.zeenews.com [last accessed 24 May 2011]. 
expressing discontent with the existing pattern of bilateral economic relations (STRAUSS; SAAVEDRA, 2009). Representatives of major Brazilian construction firms maintain that they are quietly winning African infrastructure contracts because they try to minimize the use of imported labour. Moreover, some African countries are pressing for revised contract terms that bring in the investment in a manner that offers the needed technical and managerial skill transfers.

A final point attached to the development of infrastructure is that it is often not provided as foreign aid, but as a commercial investment. Anecdotal evidence suggests that the risk tolerance amongst the rising number of Southern-based multinational is simply higher than in the North. Difficult questions of how to cope with the fuzzy zones between formal and informal approaches to governance structures in business and negotiations familiar to Southern actors represent a strange and confusing land for Northern businesses. More importantly, they create a significant tax on FDI and export financing in the form of political risk premiums for Northern financing. Southern foreign policy priorities support a more pioneering approach to market opening, with state-run banks in countries such as Brazil and China providing exportfinancing loans for infrastructure development on a scale unmatchable by the World Bank group.

A related issue pertains to the question of development results. Although DAC-member development agency programming has enjoyed laudable results in some specific areas, most notably health care and education, the simple reality is that governments from the new development partners have endogenously experienced far greater anti-poverty achievements than all the Northern donors combined. Domestically devised programs in countries such as Brazil, China and India are working. Indeed, some of the development programs from the South are increasingly being championed by institutions such as the World Bank, with initiatives such as conditional cash transfers receiving a great deal of recent attention (FISZBEIN; SCHADY, 2009). Development advice and ideas transferred through South-South cooperation consequently carry a salience and relevance that can be lacking in North-South transfers. Even in surging economies such as Brazil and China development remains the overriding public policy priority and central challenge to be addressed on the route to lasting political and economic stability. 
As Ngaire Woods has pointed out (2008), the new development actors bring an element of competition into development assistance programming. Part of the concern being raised by some close observers, including Rwandan president Paul Kigame, is that the conditionality and financial security that comes with aid flows from DAC-members is discouraging a responsible approach to public policy (KIGAME, 2009; MOYO, 2006). It is also restricts the sorts of policies that leaders of developing countries can consider, which is deeply problematic given the extent to which successful development currently appears to be attached to slightly heterodox policy approaches in such widely differentiated countries as China, Brazil, Bolivia, Argentina, India, Botswana and Ecuador. Commercial agreements with the new development partners carries the additional attraction of bringing the sorts of large investment flows that dwarf foreign aid and are often not forthcoming from the North. Underpinning these issues is a persistent concern that the political imperatives guiding DAC-member agencies may not be particularly worried about human development, focusing instead on using conditionality and the Bretton Woods Institutions as mechanisms of control (PEET, 2003). The combination of their own experiences and the tentative sense of global Southern fraternity works to make the new development partners distrustful of DAC-generated frameworks, strengthening the existing sense of independent international engagement' (RICUPERO, 2009).

\section{Institutional Structures and Directions in South-South Cooperation}

Searching out the governmental organ responsible for the coordination and delivery of South-South cooperation is not a universally easy task. There is no easy list such as that kept by the DAC for identifying which government department or agency is responsible for South-South cooperation and how much they spend. In cases such as those found in the Gulf States there are readily identifiable national and regional agencies, but their activities may be eclipsed by the private actions of ruling families, or the clarity of their policy decision and priority processes may be greatly obscured by monarchical patterns of national governance. Other countries poised between the 'developed' and 'developing' world face a delicate political balancing act of providing development cooperation for foreign policy reasons while simultaneously having 
to carefully obfuscate the amount spent to avoid awkward questions in national legislative bodies and the national media.

The interesting element of South-South cooperation is that in several instances the agencies used to coordinate incoming flows of development cooperation are now being used to organize outflows. In some cases this has meant only minor institutional shifts, often within the foreign ministry, but in others it has resulted in a significant strengthening of international cooperation institutions and discussion of the establishment of near-free standing overseas development agencies in Brazil, and South Africa. If we remove China and India from the mix, a common feature that appears is a tentative move from existing DAC-member agencies to pursue trilateral initiatives, which is something that has been embraced particularly effectively by the German GTZ and Japan's JICA, and to a lesser extent by most of the other members of DAC. In large part this desire to pursue trilateral programming is a reflection of the limited budgets available for South-South cooperation, resulting in a preferred mode of trilateral cooperation that strongly resembles a DAC-member agency contracting a Southern government to provide technical cooperation programming in a third country.

To give a sense of the differing approaches to coordinating South-South cooperation as well as well as the sort of activities undertaken, attention will now be turned to providing a snapshot of a selection of representative countries: Brazil, China, India, and South Africa. While this list is far from representative of all of the countries engaging in South-South cooperation, it does provide a useful cross-section of the differing scales of engagement, institutional arrangements, thematic and regional focuses, and engagement in trilateral programming.

\section{Brazil}

During the Lula presidency (2003-2010) South-South technical cooperation assumed an important role in Brazilian foreign policy and formed the backbone for expanded engagement with Africa (SARAIVA, 2010; DÁVILA; JERRY, 2010). In part South-South cooperation was pursued to support regional stability, notably with Paraguay and Bolivia. It also helped to expand Brazil's commercial presence in Africa. Bilateral programming has consequently focused on South America, the Community of Portuguese Speaking Nations, and a 


\section{Sean Burges}

selection of sub-Saharan countries that includes Ghana, Nigeria and Senegal. Nevertheless, there is a clear sense within the foreign ministry and presidency that South-South cooperation is not being strategically positioned to boost individual bilateral relationships, but rather formed an important strut of Lula's international platform of a Southern solidarity approach to mutual development.

Although the Brazilian Cooperation Agency (ABC - Agência Brasileira de Cooperação) has an active webpage that provides links to all of the projects it is overseeing as well as contact details for many of its staff, exact budgetary details are thin and subsumed into the overarching foreign ministry financial reports. The role of $A B C$ is to receive requests for cooperation from partners and then make the arrangements between a Brazilian government executing division and the partner country in the form of a bilateral agreement. An officially sponsored study into Brazilian resources directed towards development cooperation found a total expenditure of US\$1.426 billion between 2005 and 2009. Those funds were directed to four primary activities, with international organizations receiving US $\$ 1,082.2$ million, scholarship programs US\$138.8 million, humanitarian relief US\$79.1 million and technical cooperation US\$125.6 million. While all four of these areas fall within the DAC definition of ODA, the one most commonly associated with foreign aid is technical cooperation. Significantly, this expenditure line is growing quickly in Brazil, moving from US\$11.4 million per annum in 2005 to US\$48.9 million in 2009, and encompassing over 400 projects in 58 different countries (IPEA, $2010)$.

Nineteen different Brazilian government ministries and agencies have been involved in the provision of South-South cooperation, with $81 \%$ of programming being pursued by five ministries: foreign affairs, education, health, agriculture and science and technology. Three agencies that stand out as particularly effective implementing organizations are EMBRAPA (agricultural research) FIOCRUZ (public health) and SENAI (industrial training). Thematic priorities are biofuels, agriculture, health and professional education. The approach send Brazilian specialists abroad to provide the training necessary to create self-sustaining programs in the partner country. Costs such as plane tickets are covered by $\mathrm{ABC}$, but the salaries of workers sent on mission and 
associated expenses are covered by the separate government agencies. The defacto total value of delivered programming in DAC terms is consequently likely in the $\$ 750$ million to $\$ 1$ billion dollar range. Technocrats at ABC are actively seeking to leverage their limited budget into expanded programming through trilateral MOUs, and have signed agreements with Japan, Germany, UK, Spain, USA, France, Italy, Canada and Australia (CABRAL; WEINSTOCK, 2010).

There is surprisingly little opposition in Brasília to the existence or operation of ABC. The biggest complaint is about a lack strategic focus clarity of exactly what role South-South cooperation should play in the larger foreign policy context. Management of $\mathrm{ABC}$ is aware of these concerns and is working increase its institutional presence through expanded staffing, plans to create a development officer career stream and, ultimately, the formation of a free standing agency that operates with a budget independent of the foreign ministry. The question is what organizational form this agency should take, if it is created, and to what extent useful lessons can be learned from the various models found within the DAC membership.

\section{China}

Outside of the DAC China has perhaps the most extensive development cooperation system and the longest history in the field. Twenty different government ministries, offices and agencies are engaged in development cooperation. Officially, the 2004 ODA spend for China was US\$731 million, with updated figures pointing to a total spend of 256.29 billion yuan or US $\$ 40.2$ billion. Despite efforts in an April 2011 White Paper to provide some clarity of total spend, as much for internal policy-making purposes as to allay external concerns, completely accurate figures remain difficult to obtain. In part this is because not all data appears to be centrally reported. Confusion is added to the mix when attention is turned to low-cost, but not concessional loans and the FDI of state-owned/controlled enterprises. What is clear is that three organizations are responsible for coordinating development assistance. The Department of Aid to Foreign Countries in the Ministry of Commerce is responsible for $90 \%$ of the declared ODA spend. The rest is accounted for by activities of the Ministry of Foreign Affairs and concessional lending from the Eximbank. Line ministries are called upon to provide technical cooperation and 


\section{Sean Burges}

staff for missions. A critical point to keep in mind when evaluating the declared ODA spend is that Chinese salaries are a fraction of those found in DAC governments, and state employees are generally seconded to development projects without a substantial variation in their base salary.

Development cooperation has been part of the Chinese policy milieu since the early days of Mao. The result is a set of clear guiding principles for development assistance: promote peaceful international relations and cooperation; be based on and support relations of equality and respect; be based on mutual support in international affairs; offer assistance within China's capacity; and result in win-win cooperation that contributes to China's positive international reputation. The foreign policy imperative behind Chinese development cooperation programming is revealed in the pattern of geographic concentration, which in 2009 saw 45.7\% destined for Africa, 32.8\% for Asia, 12.7\% for Latin America and 8.8\% for other areas. ${ }^{8}$

In 1998, the Chinese government began to run seminars for officials. The departments involved and the scale and scope of such training programs have expanded rapidly. By the end of 2009, China had run over 4,000 training sessions of different types that were attended by some 120,000 people, including interns, managerial and technical personnel and officials. These trainees were from over 20 fields, including economy, diplomacy, agriculture, medical and health care, and environmental protection. At present, roughly 10,000 people from developing countries receive training in China every year.

The key themes found in Chinese development cooperation are infrastructure, agriculture, health, and capacity building. Increasing attention is being turned towards capacity building and training initiatives. A program to provide training to 15,000 African professionals was announced at the November 2006 China-Africa Cooperation Forum. This was designed to build on existing programs that Chinese officials hold up as having by 2009 trained some 120,000 people through 4,000 different sessions in over 20 fields. At the time of the 2011 White Paper's publication official estimates were that roughly 10,000

${ }^{8}$ Republic of China, "China's Foreign Aid," Information Office of the State Council of the People's Republic of China, Beijing (April 2011): http://news.xinhuanet.com/english2010/china/201104/21/c_13839683.htm [last accessed 25 June 2012]. 
people from developing countries received some form of training in China each year. Backing this is a concerted program of Chinese FDI in developing regions that follows the sort of frontier spirit found in the North America of the 1800s. In a wider development industry context, the move to untied aid has provided a major opportunity for China with Chinese firms becoming major contestants for World Bank contracts. While new to Northern eyes, in reality this sort of integrated approach represents a return to the sort of policies used in the $1960 \mathrm{~s}$ and 1970 s to spread Western economic influence

\section{India}

Foreign aid is playing an increasingly large role in India's quiet contest with China for influence in South Asia and now in Africa. This helped stimulate the May 2011 announcement of heavily expanded programming for Africa, including a three-year, $\$ 5$ billion aid package on top of a $\$ 700$ million expansion in training programs. ${ }^{9}$ Greater engagement with Africa comes on top of regional work on infrastructure, education and health programming in countries such as Bhutan, Nepal, Afghanistan and Myanmar. Where the money is coming from within the Indian government and exactly how much is being spent remains a bit unclear. Indeed, turf wars between different departments conspired in 2010 to finally kill efforts to create an India International Development Cooperation Agency (MITRA, 2010). The bulk of Indian development cooperation activities are run through the established channels of the Ministry of External Affairs, which declared a $\$ 420$ million spend in $2007-2008$, and the Ministry of Finance, which announced a 2007-2008 spend of about $\$ 1$ billion through loans and credits. Very little of this money is given in the form of cash grants, and questions about rights and democracy are often attached to the support agreements.

Under the Indian accounting system, funds declared as development cooperation spending generally cover items such as project assistance, purchase subsidies, lines of credit, travel costs and technical training costs. Indeed, it is this latter item that represents a significant portion of Indian programming. The Indian Technical and Economic Cooperation program trains approximately

\footnotetext{
${ }^{9}$ Zeenews, 2011.
} 


\section{Sean Burges}

3,000 people a year and has over 40,000 alumni. Over $50 \%$ of the training offered through this program takes place in the information technology sector. Technical training is India's focus in Africa, with an emphasis on programs for civil servants and state firm employees, often delivered through India's Special Commonwealth African Assistance Program. Private business is also encouraged to expand throughout the South, but the Indian government is able to do little more than encourage and offer technical training programs as political support because it lacks the financial muscle of China or the exportoriented national development banks of Brazil.

Although India is a participant in a number of multilateral funds such as the UN Democracy Fund and the Special Commonwealth African Assistance Project, there is a great deal of reluctance to engage in trilateral programming. In large part this is because there is a clear sense that development cooperation is underpinned by foreign policy prerogatives. As such, the Indian government is intent on ensuring that any development cooperation that it provides works to strengthen the country's regional and international reputation pointing to a clear preference for bilateral programming (STUENKEL, 2010). Understanding exactly what this might involve is difficult because of the lack of published policy papers and clear statements about programming direction and priorities beyond statements that assistance provision is guided by Panchsheel principles of mutual assistance while respecting sovereignty and autonomy in a noninterfering manner (KATTI; CHAHOUD; KAUSHIK, 2009).

\section{South Africa}

The main mechanism for South African development programming is the newly created South African Development Promotion Agency (SADPA), which is specifically envisioned as a

"vehicle to advance foreign policy, as informed by the domestic development agenda ... and to create the political, economic and social space to fight poverty, underdevelopment and marginalization of Africa and the South."(REPUBLIC OF SOUTH AFRICA, 2011).

One of the prime motivations for this is to organize and better control the substantial development cooperation coming from South Africa, which 
supports the core foreign policy priorities of being positively embedded in Africa and advancing South-South cooperation (REPUBLIC OF SOUTH AFRICA, 2011). This is particularly important as the aim is to provide $0.2-0.5 \%$ of GDP in assistance in coming years. In 2006 the estimated ODA spend by South Africa was between US $\$ 363$ and US $\$ 475$ million, which was part of a total transfer to African countries estimated at US\$2.79 billion. Wrapped within this larger figure are a number of expenditures on regional security, trade and infrastructure that do not fit within generally accepted ODA definitions. The clear point is that the South African government has decided that it must contribute substantially to regional development for two reasons. First, there is a strong desire to maintain a position of regional leadership. Second, the government wants to ensure that it is not overwhelmed by a flow of economic and humanitarian migrants.

The three main goals of South African South-South cooperation are the strengthening of institutions, supporting NEPAD, and improving bilateral relations. Programs are consequently focused on a set of guiding priorities, which include cooperation with African countries, renewing Africa, building democracy and good governance, preventing conflict, development, humanitarian relief and human resource development. These strategic guidelines result in about $55 \%$ of South-South cooperation expenditure going to broad areas in the defense category and $36 \%$ on education. Approximately $70 \%$ of the funds spent go to programming in members of the Southern African Development Community.

South Africa has a vibrant NGO sector, which provides important contributions to national South-South cooperation programs. Particular emphasis is placed on using phrasing such as "development partner" in lieu of more politically loaded terms such as 'donor'. With this in mind, programming is pursued with a number of multilateral institutions, including the $\mathrm{ABD}$, UNHCR, UNICEF, IDA, SADC, UNDP, UNIDO, WHO, FAO, WFP, and the Red Cross. Trilateral programming, currently coordinated through the National Treasury, is an area of growing interest with programs already underway with Netherlands, Switzerland, Sweden, Norway and Belgium. The notable characteristic of SADPA is that from its inception it is being created with a detailed accountability, financial management, and results-based managed structure that bears remarkable similarities to the governance frameworks of 
DAC-member agencies. ${ }^{10}$ This is not particularly surprising given the importance attached to trilateral programming as well as the clear strategic decisions within the Department of International Relations and Cooperation to expand assistance provision both as a national development tool and as a device for improving the regional security situation.

\section{Tentative Conclusion From Ongoing Research}

Given the long linkage between foreign policy ambitions and the provision of development assistance (MORGENTHAU, 1962; LUMSDAIN, 1993), it is hardly surprising that emerging market countries have turned to development assistance to shore up their growing international economic and political insertion. ${ }^{11}$ Although there are elements of altruistic 'Southern solidarity' in the rising flows of development assistance from the new development actors to low income countries, the dominant prerogatives are economic and national security in nature. This points to a series of tentative conclusions that can be drawn from the preliminary survey in this paper.

The first is that a country does not have to be a member of the DAC in order to provide development cooperation assistance. Indeed, some of the positive results being achieved by non-DAC members suggest that operating outside of the DAC frameworks may be a good thing (WOODS, 2008).

A second obvious conclusion is that South-South cooperation is not a new phenomenon. China has been engaged in foreign development cooperation for decades and UN-supported South-South cooperation initiatives have been running since the $1970 \mathrm{~s}$. What has changed in the contemporary context is that the necessary funds, administrative ability and industrial capacity to drive effective development programming can now be found easily in the South.

\footnotetext{
${ }^{10}$ South Africa, "Establishment of SADPA."

11 Chrispim Marin, "Brasil amplia presença internacional para reforçar política externa Sul-Sul," $O$ Estado de São Paulo (6 December 2009); Ngaire Woods, "Whose Aid?"; Peter Kragelund, "The Return of Non-DAC Donors to Africa: New Prospects for African Development?" Development Policy Review 26 (5) (2008): 555-584; Manning, "Will 'Emerging Donors' Change the Face of International Cooperation?"; ECOSOC, "Background Study for the Development Cooperation Forum"; Sven Grimm, John Humphrey, Erik Lundsgaarde and Sarah-Lea John de Souza, "European Development Cooperation to 2020: Challenges by New Actors in International Development," EDC 2020 Working $\begin{array}{llll}\text { Paper, } & \text { No. } & 4 & \text { (May }\end{array}$ http://www.edc2020.eu/fileadmin/Textdateien/EDC2020_WP4_Webversion.pdf.
} 
The third point is a useful reminder for DAC-based advocates of sustained or increased levels of foreign aid, namely that development assistance is most sustainable when it is grounded in the national interest. This is not a new proposition and can be found in some of the earliest scholarly examinations of foreign assistance (MORGENTHAU, 1962). While the cases set out in this paper are often publicly wrapped in a rhetoric of Southern fraternity and good international citizenship, the underlying reality is that the development cooperation is being provided to advance strategic objectives, whether it be regional security, market access, resource access, international support, or simple increases in global prestige. This is doubly important given the stillconsiderable development challenges that the new development parters often face at home. The critical lesson for DAC-members from this is that there does not have to be a contradiction to doing good through development assistance and framing policies around and advancement of the national interest.

A fourth point relates to best practices in the delivery of development assistance. The rise of the emerging market countries has made it abundantly clear that there are policies and programs in developing countries that work exceptionally well. This can create a bit of a cultural challenge for DAC-member development agencies that treat the possibility of effective and efficient innovation in the South as improbable. But the reality is that solutions to many challenges may already exist in the South where the daily policy context is development.

Fifth, it is results that matter, not process. Many of the DAC members express the same sentiment while becoming moribund in procedural arguments. Countries such as Brazil, China, India and South Africa are looking to found development cooperation agencies to ensure coordination and coherence of programming, not to satisfy the accounting and reporting requisites of the OECD. Moreover, far more direct approaches to results are being taken, with the ultimate indicator being whether the project did what it said it would, not that all of the correct boxes were checked along the way. In a sense this far more direct approach has to be taken because the pool of available resources is significantly smaller, bureaucratic capacity quite a bit lower, and the stakes for failure higher for both parties.

Complaints about predatory Chinese activities in Africa point directly to the final lesson, namely that development assistance is not enough. As was 


\section{Sean Burges}

argued above, a distinction needs to be made between development cooperation and business-driven foreign direct investment. The confusion arises in the Chinese case because the volumes of financial flows are so high. What gets overlooked is the diversity of instruments being used to pursue these ventures and the fact that China, like Brazil, India and the Gulf States is willing to invest in areas that are considered too risky for Northern firms. Moreover, the sheer number of people being trained each year in Brazil, China, India and South Africa points to a revival of the original ethic behind programs such as the Fullbright and Chevening scholarship schemes, namely a real transfer of capacity and technical knowledge that also creates soft power linkages. The result is a more policy coherent approach to development cooperation, which is founded on a more holistic approach that sees expanded national development as predicated on wider Southern development because the future possibilities from Northern market access are very limited.

One issue not addressed in this paper is the possibility that the expanded volume and range of South-South engagement in cooperation will create new problems or reverse existing gains, most notably through the creation of new debt loads and lack of coordination amongst existing programs. While there is much to this concern, the abiding reality is that the DAC itself is still grappling with in-country and cross-country coordination to the point where member agencies are still highly reluctant to accept the probity of reporting and assessments from their counterparts because the documentary templates differ. Understandably, developing countries are not waiting for this issue to be resolved and instead taking advantages of the new opportunities that come from South-South development cooperation, opportunities that increasingly extend beyond foreign aid.

\section{REFERÊNCES}

AKAMATSU, Kaname. A Historical Pattern of Economic Growth in Developing Countries: The Developing Economies, 1962.

BLAISE, Séverine. On the Link Between Japanese ODA and FDI in China: A Microeconomic Evaluation Using Conditional Logid Analysis. In: Applied Economics 37, 2005. 
BRÄUTIGAM, Deborah. 'Flying Gees' or 'Hidden Dragon'? Chinese Business and African Industrial Development. In: ALDEN, Chris; LARGE, Daniel; OLIVEIRA, Ricardo Soares de. China Returns to Africa: A Rising Power and a Continental Embrace. New York, Columbia University Press, 2008.

Deborah. The Dragon's Gift: The Real Story of China in Africa. Oxford: Oxford University Press, 2009.

BROOKS, William L. Brooks; ORR, Robert M. Japan's Foreign Economic Assistance. In: Asian Survey 25 (3), March 1985.

CABRAL, Lídia Cabral; WEINSTOCK, Julia. Brazilian Technical Cooperation for Development: Drivers, mechanics and future prospects. Overseas Development Institute, 2010.

DÁVILA, Jerry. Hotel Trópico: Brazil and the Challenge of African Decolonization, 1950-1980. Durham, NC: Duke University Press, 2010.

EASTERLY, William. The White Man's Burden. New York: Penguin, 2006.

ECOSOC. Background Study for the Development Cooperation Forum: Trends in South-South and Triangular Development Cooperation. New York: United Nations, Apr. 2008.

FISZBEIN, Ariel; SCHADY, Norbert. Conditional Cash Transfers: Reducing Present and Future Poverty. Washington, DC: IBRD/World Bank, 2009.

GRIMM, Sven; et al. European Development Cooperation to 2020: Challenges by New Actors in International Development. EDC 2020 Working Paper, n.4 (May 2009):

<http://www.edc2020.eu/fileadmin/Textdateien/EDC2020_WP4_Webversion. pdf $>$.

IPEA. Cooperação Brasileira Para o Desenvolvimento Internacional 2005-2009. Brasília: IPEA/ABC, 2010.

KATTI, Vijaya; CHAHOUD, Tatjana; KAUSHIK, Atul. India's Development Cooperation: Opportunities and Challenges for International Development Cooperation. In: German Development Institute Briefing. Paper n.3, 2009.

KIGAME, Paul. Africa Has to Find Its Own Way to Prosperity. Financial Times 7 May 2009.

KRAGELUND, Peter. The Return of Non-DAC Donors to Africa: New Prospects for African Development? Development Policy Review 26 (5), 2008.

LAMY, Pascal. The Changing Landscape of the WTO. Speech to the Japan Institute of $\begin{array}{llll}\text { International } & \text { Affairs. } & 16 & \text { March }\end{array}$ <http://www.wto.org/english/news_e/sppl_e/sppl221_e.htm>. Accessed 6 June 2012.

LANDIM, Raquel. OCDE corteja países emergentes. In: O Estado de São Paulo, 7 December 2009.

LUMSDAIN, David Halloren. Why Was There Any Foreign Aid at All? In Moral Vision in International Politics: The Foreign Aid Regime, 1949-89. Princeton, NJ: Princeton University Press, 1993.

MANNING, Richard. Will 'Emerging Donors' Change the Face of International Cooperation? In: Development Policy Review 24 (4), 2006. 
MARIN, Chrispim. Brasil amplia presença internacional para reforçar política externa Sul-Sul. In: O Estado de São Paulo, 6 December 2009.

MARKUSEN, James R; VENABLES, Anthony J. Foreign Direct Investment as a Catalyst for Industrial Development. European Economic Review 431999.

MIGIRO, Asha-Rose. A new spirit of solidarity rises in the South. Op-Ed, Financial Times. 9 December 2009.

MITRA, Devirupa. India Drops Plan for External Aid Agency. In: iGovernment.in <http://www.igovernment.in/site/india-drops-plan-external-aid-agency37739>. Accessed 25 June 2012.

MORgenthaU, Hans. A Political Theory of Foreign Aid. In :American Political Science Review, v.56, n. 2, June 1962.

MOYO, Dambisa. Dead Aid: Why Aid is not Working and How There is a Better Way for Africa. London: Allen Lane, 2009.

O ESTADO DE SÃO PAULO. Investindo no Paraguai.1 February 2011.

OECD-DAC. Is it ODA? Fact 2008 . <www.oecd.org/dataoecd/21/21/34086975.pdf>. Accessed on 6 June 2012.

PEET, Richard. Unholy Trinity: The IMF, World Bank and WTO. London: Zed Books, 2003.

PREBISCH, Raúl; "Dependence, Interdependence and Development," CEPAL Review No. 28 (Abril, 1988)

REPUBLIC OF CHINA. China's Foreign Aid. Information Office of the State Council of the People's Republic of China. Beijing. April 2011: $<$ http://news.xinhuanet.com/english2010/china/2011-

04/21/c_13839683.htm>. Accessed 25 June 2012.

REPUBLIC OF SOUTH AFRICA. Building a Better World: The Diplomacy of Ubuntu. White Paper on South Africa's Foreign Policy, 13 May 2011. <http://www.info.gov.za/view/DownloadFileAction?id=149749>. Accessed 25 June 2012.

Establishment of SADPA: Presentation to the NCOP Select Committee on Trade and International Relations. Department of International Relations and Cooperation. $\quad 3 \quad$ August 2011. <http:/www.safpi.org/sites/default/files/110803sadpa-edit.pdf $>$. Accessed 25 June 2012.

RICUPERO, Rubens. Brazil Political and Business Comment. Interview of Rubens Ricupero, former Brazilian finance minister. 8 June 2009. http://www.brazilpoliticalcomment.com.br/content/view/262/0/lang,en

SANBORN, Cynthia A; TORRES, Victor, La Economía China y las Industrias Extractivas: Desafíos para el Perú (Lima: Centre de Investigación de la Universidad del Pacífico; CooperaAcción, 2009).

SARAIVA, José Flávio Sombra. Áfria parceira do Brasil atlântico: Relações internacionais do Brasil e da África no início do século XXI. Belo Horizonte: Fino Traço, 2012

SHARMA, Ruchir. Bearish on Brazil: The Commodity Slowdown and the End of the Magic Moment. In: Foreign Affairs, v.91, n. 3, May-June, 2012. 
SILVA, Luiz Inácio da. A nova geografia do comércio: Cooperação Sul-Sul em um mundo cada vez mais interdependente. Discurso na sessão de debate da XI UNCTAD, São Paulo, Brazil, June, 14 $4^{\text {th }}, 2004$.

STRAUSS, Julia C.; SAAVEDRA, Martha. China and Africa: Emerging Patterns in Globalization and Development. Cambridge: Cambridge University Press, 2009.

STUENKEL, Oliver. Responding to Global Development Challenges: Views from Brazil and India. In: German Development Institute Discussion Paper, n. 11, 2010.

SUNKEL, Osvaldo; e ZULETA, Gustavo; Neo-Structuralism versus Neo-Liberalism in the 1990s, CEPAL Review No. 42 (Dezembro, 1990).

UNITED NATIONS GENERAL ASSEMBLY. Promotion of South-South Cooperation for Development: A Thirty-Year Perspective. Report of the Secretary General, Doc 64/504, 27 October 2009.

UNITED NATIONS. Special Unit for South-South Cooperation: What is South-South Cooperation? 2012.

<http://ssc.undp.org/content/ssc/about/what_is_ssc.html $>$. Accessed 6 June 2012.

. United Nations Special Unit for South-South Cooperation: Buenos Aires Plan of Action. 1978. <http://ssc.undp.org/Buenos-Aires-Plan-ofAction.22.0.html>.

WOODS, Ngaire. Whose Aid? Whose Influence? China, Emerging Donors and the Silend Revolution in Development Assistance. In: International Affairs 84 (6), 2008. 


\section{Sean Burges}

ABSTRACT

This paper looks at the rise of South-South cooperation as an alternative to traditional foreign aid provision by member agencies of the OECD's Development Assistance Committee. It tracks the rise of South-South cooperation and places it in the context of contemporary approaches to development programming, arguing that there are valuable lessons for the North in this Southern-driven approach to development.

\section{KEYWORDS}

Development; South-South; Cooperation; 


\title{
COLONIAL GLOBALISATION TO POSTCOLONIAL GLOBALISATION: NON- ALIGNMENT AND SOUTH-SOUTH COOPERATION $^{1}$
}

\author{
Aditya Mukherjee ${ }^{2}$
}

The revisionist view of colonialism which seeks to portray colonialism in a positive light has now become once again fashionable. This is particularly true for countries which in recent years have been doing very well, countries in East, Southeast and South Asia such as China, South Korea, Indonesia and India. Surprisingly, the view that is now being argued is that the current success of this region is closely connected with the colonial experience. It is suggested that it is the colonial opening up, which created the conditions for the economic take off in these countries.

A peculiar argument has emerged which tries to claim the credit for the current success of this region to their colonial past. By a virtual sleight of hand, the two processes of globalisation, one under colonialism, between the $16^{\text {th }}$ and the 19th centuries; and the other after the Second World War adopted by independent nation states are conflated. The fact that in the colonial period there was an enormous movement of labour and capital, and an enormous expansion of trade is being conflated with a similar expansion, in fact in some ways even a larger expansion, of trade and movement of capital that was

1 Paper read at the Brazilian Seminar of International Strategic Studies (SEBREEI), Porto Alegre, Brazil, 22 June 2012.

2 Director, Institute of Advanced Study, Jawaharlal Nehru University, New Delhi. (mriduladitya@gmail.com) 
witnessed in the $20^{\text {th }}$ century, especially since the 1960 s. No mention, of course, is made of the fact that in the latter phase labour did not move as easily as it used to move in the early colonial phase or of the fact that the earlier process occurred under colonial hegemony for colonial purposes while the latter process was essentially mediated through independent nation states in a vastly changed global capitalist system. ${ }^{3}$

In this colonial understanding, the "bad" phase in the postcolonial countries like India was the nationalist, 'protectionist' phase which attempted to unstructure colonialism and promote national development. That is, in the Indian case, "the fly in the ointment' was the Nehruvian phase. The "good" phases were the colonial period, when the colonial economies were opened up to the world, and again the open economy after the so-called 'neo-liberal' economic reforms in the second half of the $20^{\text {th }}$ century.

This kind of position is found not only in the writings of Niall Ferguson, the very title of whose book 'Empire: How Britain Made the Modern World' sums up his basic conclusion that Britain made the modern world through the empire (FERGUSON, 2003). One finds such positions taken in the writings of Tirthankar Roy whose neo-colonial work published by Oxford University Press as the Economic History of India would in my opinion embarrass even the conservative British Viceroy Lord Curzon because of the blatant manner in which it argues the colonial paradigm (TIRTHANKAR, 2006). Similar positions are taken currently by economists like Lord Meghnad Desai, a former Marxist, who has moved considerably to the Right.

The basic position argued by these neo-colonialists is that colonialism had a positive impact on the colonies and that particularly the expansion of trade, creation of transport and communication infrastructure, etc., under colonialism were very beneficial for the colony and created positive initial conditions in the postcolonial situation. It is also argued that the early postcolonial phase which was relatively protectionist was what was wrong in the development of these societies. As Meghnad Desai put it "the first 40 years of India's Independence (including the Nehruvian years) were wasted." He also

\footnotetext{
${ }^{3}$ For a brilliant analysis of the globalisation occurring post World War II, with world capitalism having reached a new phase, see Eric Hobsbawm, Age of Extremes: The Short Twentieth Century (Harmondsworth: Penguin, 1994).
} 
argued that colonialism actually developed India and at independence left India among the top ten industrial countries of the world (DESAI, 2009)! I have in detail critiqued these colonial views elsewhere (MUKHERJEE, 2007; 2010).

The Nehruvian effort at "unstructuring" colonialism and move in the direction of independent economic development was also critiqued, if not rubbished, by the opposite end of the ideological spectrum, based on a completely different set of assumptions. The orthodox Left, drawing its position from the 1928 VI Congress of the Comintern (Communist International), argues that no independent development is possible in not only the colonial situation but even after the colonial society has won political independence. It is argued that colonial economies and even postcolonial 'peripheral' economies necessarily developed in a manner that led to the further structuring in of dependence, making it impossible for them to break out of this dependent status unless these societies broke out of the capitalist path altogether and went over to socialism. This view was argued by Baul Baran in the 1950s, when a major spurt of decolonization was taking place and was taken up, somewhat understandably, by some of the dependency theorists in Latin America like Gunder Frank, as well by recent Marxist and neo-Marxist scholars like Samir Amin, Hamza Alavi. Given the a priori assumptions of this line of thinking India during Nehru's leadership could not have developed independently as India had not gone socialist. In fact, the Communists immediately after independence declared that this independence was not 'real' and Nehru was 'a running dog of imperialism'. However, this line of thinking, termed the CBF Model (Comintern-BaranFrank) by Bipan Chandra has been strongly critiqued in India from within the Left (CHANDRA, 2012) and it has been questioned elsewhere too (CARDOSO; FALETTO, 1979). I have done an extensive critique of this position elsewhere. ${ }^{4}$

In this paper, I shall first, in brief, argue that the colonial legacy did not create positive "initial conditions" and that the path to development necessitated the 'unstructuring' of colonialism. Second, I shall outline elements of the Nehruvian strategy for 'unstructuring' colonialism showing that the

4 See Aditya Mukherjee and Mridula Mukherjee, "Imperialism and the Growth of Indian Capitalism in the Twentieth Century", Economic and Political Weekly, 12 March 1988; and Aditya Mukherjee, Imperialism, Nationalism and the Making of the Indian Capitalist Class (New Delhi: Sage, 2002). 
Nehruvian period rather than being wasted or leading to further dependency actually promoted independent development and created the structural conditions for rapid development in later years. The Nehruvian strategy, which I call the 'Nehruvian consensus' at independence, was a product of a particular historical conjuncture. 'Non-alignment' was one aspect of this consensus. The historical conjuncture was constituted by a number of factors such as the legacy of colonialism or the "initial conditions" at the point of independence, the nature of world capitalism and the global balance of power at that time.

\section{Colonial Legacy}

A typical colonial economy often acquired features which though they appeared to be 'modern' or capitalist, they in reality performed completely different and distinctly colonial roles as they occurred within the colonial framework. For example, a colonial situation could witness, as it did in India, a high degree of commercialisation (or generalised commodity production), rapid growth in transport and communications, close integration with the world market and a high degree of 'potential investible surplus' raised from within the economy all features associated with capitalist development. Yet in the colonial context all these developments led to capitalist development in the metropolis but further colonial structuring in the colony. It ended up, to use the early Indian nationalist, Tilak's, expressive phrase, "decorating another's wife", while disfiguring one's own.

In the Indian colonial economy, which was forcibly internally disarticulated and extroverted, the above changes did not stimulate internal intersectoral exchanges between Indian agriculture and Indian industry, or between Indian consumer goods industry and capital goods industry. ${ }^{5}$ The circuit of commodity circulation was completed via the metropolis where colonial agriculture was linked to metropolitan industry, or colonial consumer goods industry (if and when it was allowed to develop) with metropolitan capital goods industry; the multiplier effects of these exchanges were thus transmitted abroad. Similarly, the surplus generated in the colonial economy

\footnotetext{
5 The question of exchange between the sector producing capital goods for the capital goods industry and the capital goods industry did not arise.
} 
did not lead to extended reproduction through investment (the key feature which distinguishes capitalism from pre-capitalist modes of production) thus raising the organic composition of capital and productivity to a higher level on a significant scale within the indigenous economy, but facilitated this process in the metropolis (MUKHERJEE, 2010; ALAVI, 1974). Traditional artisanal industry was destroyed (LUTSKY, 1969), (i.e., a process of de-industrialization occurred in a country which was the world's largest exporter of textiles in the precolonial era) and not replaced with modern capital intensive industry on any significant scale.

Capitalism did not grow in agriculture either. Commodity production in agriculture was in response to a "forced commercialisation" to primarily meet the colonial state's revenue demands and not with a capitalist rationality, i.e., to earn profit for investment. Typically, agriculture witnessed a high degree of differentiation but it did not lead to capitalist farming through extended reproduction. The petty mode of production was perpetuated in agriculture with the large estates being let out to tenants with small holdings who continued to cultivate at more or less the same traditional levels of technology. ${ }^{6}$ Moreover, agricultural output and exports, even when they grew, ${ }^{7}$ they remained articulated with metropolitan industrial and other needs.

Colonialism has to be viewed and evaluated as an overall structure. Growth in one or the other sector of the colonial economy or society cannot be evaluated as 'partial' development (to be offset against the lack of such growth in another sector) if that sectorial growth was instrumental in creating the colonial structuring which led to overall stagnation and even decline. The

\footnotetext{
${ }^{6}$ This tendency has been shown to be true even in areas like Punjab, in India, which has been wrongly claimed as moving in the direction of capitalist agriculture in Mridula Mukherjee, Colonialising Agriculture: The Myth of Punjab Exceptionalism (New Delhi: Sage, 2006). See also Aditya Mukherjee, "Agrarian Conditions in Assam 1880- 1890: A Case Study of Five Districts of the Brahmaputra Valley", The Indian Economic and Social History Review, Volume XVI, Number 2, Apr-June 1979, pp. 207-232, for a discussion on how colonial structuring of Indian agriculture occurs in a vastly different situation (from Punjab).

${ }^{7}$ In some instances, such as the sugar plantations of Indonesia in the late $19^{\text {th }}$ century, they were operated by foreign capital at high levels of investment and technology, but yet they remained totally articulated to colonial needs and had no positive effect towards growth of capitalist agriculture in Indonesia. See, for example, Clifford Geertz, Agricultural Involution: The Process of Ecological Change in Indonesia (Berkeley: University of California Press, 1963); J. S. Furnivall, Netherlands India (New York: 1944); and id., Colonial Policy and Practice (New York: New York University Press, 1956).
} 
development of railways, foreign trade, telegraph, agrarian transformation, a colonial civil service, etc., occurred in a manner that they became critical instruments in converting the pre-capitalist and sometimes emerging capitalist societies $^{8}$ into a stillborn colonial structure. The very instruments of the subversion of modern capitalist development in favour of colonial structuring cannot be treated as the 'residual' or 'partial' benefits of colonialism, a fallacy which unfortunately creeps into the thought of otherwise staunch liberal nationalists at the highest level and even some Marxists.

The structural distortions created by colonialism made the future transition to self-sustained growth much more difficult. It required the overthrow of colonialism, and the 'unstructuring' of the colonial structure for India to start its attempt to build independent capitalism after colonialism for nearly two hundred years ravaged its economy and society and deprived it of the opportunity of participating in the process of modern industrial transformation occurring in other parts of the world. Despite certain positive developments in the Indian economy in certain areas, ${ }^{9}$ since W.W.I till 1947, India remained essentially backward and structurally colonial. The Indian economy at independence was still basically dependent on a stagnating, low productivity, 'semi-feudal' agriculture with modern industry (in 1950) contributing a mere 6 to 8 per cent of the national income and (in 1951) employing 2.3 per cent of the labour force (in 1946) (GOLDSMITH, 1983; CHANDRA, 1992).

What India inherited after two hundred years of colonial 'benevolence', which allegedly gave India the 'advantages' of 'commercialisation', 'exposure to the world market', 'transport and communication', 'a strong state', 'western scientific skills', etc., benefits that Tirthankar Roy could hardly stop listing, was a very sorry state of affairs indeed.

As Angus Maddison's monumental work shows, India was the largest economy of the world for the entire thousand years of the first millennium accounting for close to 30 per cent of the world's GDP. Till as late as the

\footnotetext{
${ }^{8}$ For example, Mohammad Ali's Egypt in the 1830s.

${ }^{9}$ I have shown elsewhere how even these positive developments were not the result of colonialism but were wrenched from it and occurred in spite of and in opposition to colonialism. See, for example, Imperialism, Nationalism and the Making of the Indian Capitalist Class (New Delhi: Sage, 2002), ch. 1.
} 
beginning of the $18^{\text {th }}$ century India's was still the largest economy with about 25 per cent of the world's GDP, more than eight times that of the United Kingdom. The decline started soon after and at the end of nearly two hundred years of colonial rule (during which Tirthankar Roy claims "colonial India experienced positive economic growth") (TIRTHANKAR, 2006). India's share had been reduced to a mere 4.2 per cent in 1950. A few decades were needed after independence before India could sufficiently shrug off the colonial legacy and begin to gradually claw her way back into improving her share of the global pie (MADDISON, 2007). This aspect we will deal with shortly.

The impact of colonialism in human terms was traumatic and all too visible. At independence the average life expectancy was barely 30 years. The poor obviously died much younger. India was faced with acute food shortages creating near famine conditions repeatedly in different areas. The Bengal famine of 1943, just four years before the British left, claimed more than three million lives. ${ }^{10}$ Between 1946-53 about 14 million tons of food grains worth Rs.10,000 million had to be imported, seriously affecting India's planned development after independence. In 1951, 84 percent of the people (92 per cent women) were illiterate.

It was from these abysmal initial conditions that Independent India under Nehru had to commence its journey towards modernization. An important element at the beginning of this journey was the setting up of the process of 'unstructuring' the colonial structure so that the Indian economy and society was ready for take-off. We will outline below the contours of the strategy followed to unstructure colonialism.

\section{The Nehruvian Strategy}

Apart from the abysmal initial conditions an equally important element of the historical conjuncture that determined the course followed by independent

\footnotetext{
10 See Amartya Sen, Poverty and Famines: An Essay on Entitlements and Deprivation (Delhi: Oxford University Press, 1982), Appendix D, pp.195-216, for a comprehensive exercise in estimation of famine deaths during the Bengal famine. While the Famine Inquiry Commission put it at 1.5 million, Sen convincingly argues why the figure is closer to around 3 million. See also Paul Greenough, Prosperity and Misery in Modern Bengal: The Famine of 1943-44 (New York: Oxford University Press, 1982), where he argues a higher figure, and Rakesh Batabyal, Communalism in Bengal: From Famine to Noakhali, 1943 47 (New Delhi: Sage, 2005).
} 
India was the legacy of the movement, which led to the creation of the independent Indian state. Evidently, the nature of the newly born state is critically determined by the nature of the movement that leads to the creation of that state. The three basic elements of the Indian national liberation struggle, which created a deep impact on the Indian state at independence, were a commitment to anti-imperialism or sovereignty, commitment to a democratic civil libertarian framework (which inter alia meant creation of an inclusive, multicultural secular society) and the desire to maintain a pro-poor orientation. ${ }^{11}$ Particularly the first two, i.e., maintenance of sovereignty and democracy became two non-negotiables within which the Nehruvian Consensus had to function. This led to the Nehruvian attempt at industrial transformation with democracy, a unique attempt. In Nehru's words a path "unique in history". ${ }^{12}$ Never before in history was the process of transition to industrialism or the process of primitive accumulation accomplished along with democracy.

The non-negotiable commitment to democracy meant that the necessary 'surplus' required for investment in order to facilitate the transition to industrialism could not be raised on the backs of the Indian working class and peasantry or on the basis of colonial surplus appropriation as happened in other countries in the past. ${ }^{13}$

The commitment to sovereignty meant that the transition could not be accomplished with foreign aid or intervention in a manner that would make it a junior partner of any advanced country, however powerful it may be. The imperative of maintaining sovereignty was a natural pointer towards nonalignment in the post-World War II Cold War situation where the world was divided into two power blocs. The policy of non-alignment in other words was

11 See my chapter "Political Economy of the Post Colonial Indian State" in Bipan Chandra, Mridula Mukherjee and Aditya Mukherjee, India Since Independence (New Delhi: Penguin, 2008), for a detailed discussion on the impact of the Indian National Movement on the postcolonial Indian state.

12 Nehru was deeply conscious of this and often spoke about it. See, e.g., "Minutes of the fourth meeting of the National Development Council", New Delhi, 6 May 1955, File Number 17(17\&/56-PMS in Selected Works of Jawaharlal Nehru, Second Series, Vol. 28, p.371). See also my introduction to Aditya Mukherjee (ed.), A Centenary History of the Indian National Congress, Volume V, 1964-84 (New Delhi: Academic Foundation, 2011).

${ }^{13}$ See Aditya Mukherjee, "Empire: How Colonial India made Modern Britain", Economic and Political Weekly, Volume XLV, No 50, 11 December 2010, for a detailed discussion of how colonial surplus appropriation aided the process of primitive accumulation in the West. 
as much a function of the strategy of economic development chosen by India, as it was a product of the Indian national movement's commitment to world peace and sovereignty of nation states.

Nehru and the early Indian planners had correctly understood that political independence was of little value if it could not be used to acquire first economic and then intellectual independence. At independence, because of the nature of colonialism it was subjected to, India was virtually totally dependent on the advanced world for capital goods and technology for making any investment. India then produced virtually no capital goods. In 1950, India met nearly 90 per cent of its needs of even machine tools, leave alone machines, through imports. This meant that though India was politically independent it was completely dependent on the advanced countries for achieving any economic growth though investment.

This was a neo-colonial type situation, which needed immediate remedy. And this is the situation that the famous Nehru-Mahalonobis strategy tried to reverse by adopting a heavy industry or capital goods industry based industrialisation. During the first three plans (1951-65) industry in India grew at 7.1 per cent per annum. This was a far cry from the deindustrialisation process of the $19^{\text {th }}$ century and the slow industrial growth between 1914-47. More important "the three-fold increase in aggregate index of industrial production between 1951 and 1969 was the result of a 70 per cent increase in consumer goods industries, a quadrupling of the intermediate goods production and a ten-fold increase in the output of capital goods" (VAIDYANATHAN, 1983). This pattern of industrial development led to a structural transformation of the colonial legacy. From a situation where to make any capital investment, virtually the entire equipment had to be imported the share of imported equipment in the total fixed investment in the form of equipment in India had come down to 43 per cent in 1960 and a mere 9 per cent in 1974, whereas the value of the fixed investment in India increased by about two and a half times over this period $(1960-74) \cdot{ }^{14}$

${ }^{14}$ See Aditya Mukherjee, "Planned Development in India 1947-65: The Nehruvian Legacy" in Shigeru Akita (ed.), South Asia in the 20th Century International Relations (Tokyo: Institute of Oriental Culture, the University of Tokyo, 2000), and also in Bipan Chandra, Mridula Mukherjee, Aditya Mukherjee, India Since Independence, op. cit., ch.25. These paragraph's figures are from an extremely 
This was a major achievement and, as it considerably increased India's autonomy from the advanced countries in determining her own rate of capital accumulation or growth, it created the key condition for non-alignment or relative independence from both the power blocs. In my understanding no amount of diplomatic finesse could achieve and sustain the objective of nonalignment without the economic basis of relative autonomy having been created.

The heavy industry based industrialisation had to be achieved without losing India's independence as after all the whole purpose of the following this path was to achieve such an independence. As India at independence did not have a sufficiently large indigenous private enterprise to take on the massive task of developing capital goods industries the only other option was to develop it through the public sector. The option of basing the development of this sector on foreign capital did not arise as the Nehruvian consensus was that sovereignty would be achieved only if its industrial development was primarily built indigenously and was not based on foreign capital. The public sector was clearly seen as the alternative to foreign capital domination and not necessarily as an alternative to the private enterprise if it was available (MUKHRJEE, 2002).

India adopted the path of a mixed economy where a large public sector would exist in partnership with the private sector. They would be complimentary and not in contradiction with each other (MUKHRJEE, 1974). The United States, with its virtual paranoia about socialism was unwilling to help India follow this path of independent industrialisation based on a nationalised or public sector. The US insistence on the private sector and its own favoured model of development pushed India towards the Soviet Union. But then sovereignty and non-alignment meant that India would not be client state or junior partner to any of the super powers. When the US stance pushed India too hard in one direction India sought Soviet help to remain non-aligned and follow an economic path of her own choice. Soviet help did not mean that India accepted the economic framework favoured by them. Indian planning borrowed many elements of the Soviet model but was critically different in two

persuasive piece by Vijay Kelkar, "India and the World Economy: A Search for Self Reliance", Paper read at Seminar on Jawaharlal Nehru and Planned Development, New Delhi, 1980, and reprinted in Economic and Political Weekly, Volume 15, Numbers 5-7, February 1980. 
aspects. First, it created a system where private enterprise could grow in tandem with the public sector rather than a system which would abolish it altogether. Second, planning in India was to be consensual and not a command performance. I.e., every aspect of the planning strategy had to be acceptable to different sections of Indian people in a democratic manner.

Apart from increase in public expenditure the other way of reducing foreign dependence for achieving internal growth was to increase domestic savings and capital formation. Here too the years after independence saw a structural breakthrough. The last half a century of century of colonial rule (1901-1946) saw the gross capital formation in the Indian economy hover around 6 to 7 per cent of GDP (GOLDSMITH, 1983). The net capital formation during this period was perhaps nil or even negative as the drain or the unilateral transfer of Indian 'potential investible surplus' to Britain has been variously calculated to be between 5 to 10 per cent of her GDP (HABIB, 1995; HABIB, 1975; PATNAIK, 2000; CHANDRA, 2008). The first fifty years after independence on the other hand saw the annual rate of capital formation rise consistently sharply from about 9 per cent in 1950-55 to about five times the colonial rate (assuming there was no drain) in 2005-6, a whopping 33.8 per cent (ECONOMIC SURVEY, 2007). ${ }^{15}$

While reducing dependence on foreign capital and technology for making indigenous investment was one way of gaining and keeping the country's sovereignty intact there were other strategies adopted as well. India undertook a deliberate strategy of diversifying its foreign trade so that her dependence on any one country or bloc of countries was reduced. As a result the geographical concentration index (GCI) of trade with foreign countries declined sharply. GCI of India's exports declined from 0.69 in 1947 to 0.22 in 1975. There was a similar decline in GCI in case of imports. Significantly, the result of the declining GCI was that the share of the metropolitan countries of the West, which earlier dominated India's trade, declined sharply. For example, the share of UK and USA in India's exports, which was 45 per cent, in 1947 fell by more than half and by 1977 it was only 20 per cent (KELKAR, 1980). This was

\footnotetext{
${ }^{15}$ Computed from Economic Survey 2006-07 (New Delhi: Government of India, 2007), Tables 1.4, 1.5, S-
} 6 to S-9. 
partly achieved by the increase in India's trade with the Socialist bloc (which bailed out an extremely foreign exchange short India by allowing barter and Rupee trade) and other under developed countries.

The diversification was to keep dependence on any one country or bloc of countries low. The shift away from the UK and USA was however, not to lead to becoming a Soviet 'stooge'. That would defeat the whole point of nonalignment.

Care was taken to keep a similar attitude in the area of military dependence as well. India did move considerably towards the Soviet Union for its military requirement partly to offset its earlier virtual total dependence on the West in this area and partly because the Soviets offered better terms including a much higher degree of indigenization of defense equipment bought. Yet India avoided a total dependence on the Soviet Union either. If MIGs were bought so were Jaguars.

Moreover, while dependence on any one country or bloc of countries was sought to be kept low and decreasing, in the early decades after independence, the overall dependence on the outside world was also kept low. Total foreign trade (exports and imports) as a proportion of GDP remained low through the 1950 s to $1970 \mathrm{~s}$, hovering around 10 per cent (it rose to over 30 per cent in the new millennium as a result of the economic reforms which accelerated since 1991). Dependence on foreign aid was also kept low and brought down sharply. Net aid as percentage of India's Net National Product declined from 3.88 per cent in the $2^{\text {nd }}$ Plan to between 0.5 and 1.8 per cent in the 1970s (KELKAR, 1980).

Another area of concern for the maintenance of India's sovereignty and ability to stay non-aligned was India's food security. This was learnt at great cost by India in the mid-1960s when massive food shortages made India greatly dependent on the United States for supply of foodgrains under the Pl 480 scheme. This was a dependence which the United States used to keep India on a "tight leash" to use President Lyndon Johnson's shocking phrase. India was forced to experience what has been called a 'ship-to-mouth' existence and was arm-twisted into adopting economic policy measures asked for by the US (MUKHERJEE, 2011).

The quest for self-sufficiency in food was now pushed with greater urgency adopting what has been called the Green Revolution strategy. It 
produced dramatic results. The legacy of colonialism was such that at the end of colonial rule, per capita agricultural output actually fell at an annual rate of 0.72 per cent between 1911 and 1941 and food crop output fell even more sharply by 1.14 per cent per year over the same period. Food grain yields per acre were declining at 0.44 per cent between 1921 and 1946 (BLYN, 1966). No wonder at independence India was faced with chronic food shortages and famine conditions. This situation was getting reversed with Indian agriculture in the first three plans (up to 1964) growing at over 3 per cent per annum, eight times faster than in the half century preceding independence (1891-1946) (BLYN, 1966). Moreover, areas like Punjab were showing massive increases in yields with the value productivity of 11 major crops increasing by 12.5 per cent per year between 1950 and 1970 (MUKHERJEE, 2006). The combination of the land reforms and the investments in infrastructure - like irrigation, electricity, etc. -, initiated by Nehru, and the Green Revolution strategy implemented after him led to a structural break in Indian agriculture. As a result, the net imports of foodgrains declined from over ten million tons in 1966 to less than half a million ton in 1977. By the 1980s India was self-sufficient in food with buffer stocks exceeding 30 million tons. ${ }^{16}$

Last but certainly not the least Jawaharlal Nehru and the early Indian planners were acutely aware of India's backwardness and near total dependence on the advanced world in science and technology (an area left consciously barren in the colonial period) and therefore made massive efforts to overcome this shortcoming. Almost every known scientific institution in India was conceived in the Nehruvian period be it the IITs, the (BARC) Bhabha Atomic Research Centre, the National Physical Laboratory, the National Chemical Laboratory, the Centre for Scientific and Industrial Research (CSIR) and numerous such others. An unprecedented increase occurred in the educational opportunities in science and technology in the universities and institutes. National expenditure on scientific research and development kept growing rapidly with each plan. For example, it increased from Rs. 10 million in 1949 to Rs. 4.5 billion in 1977. Over roughly the same period the stock of India's

\footnotetext{
${ }^{16}$ See Aditya Mukherjee, "Agricultural Growth and the Green Revolution" in Bipan Chandra, Mridula
} Mukherjee and Aditya Mukherjee, India Since Independence, op. cit. 
scientific and technical manpower increased more than 12 times from 190 thousand to 2.32 million spectacular growth by any standards. It is Jawaharlal Nehru's brilliant and precocious anticipation of the move towards a 'knowledge society' in world capitalism and his huge emphasis in this area from the first plan itself, which has enabled post economic reform India to reap the benefits of the global opportunities in the information and the knowledge sector (MUKHERJEE, 2008).

\section{III}

In sum then, it is the reversal of the colonial structuring by creating a diversified industrialisation leading to considerable self-reliance for promoting growth, a dynamic growing agriculture creating food security, higher rates of domestic capital formation, greatly improved scientific and technical capabilities reducing foreign dependence on capital and technology which enabled India to chart out an independent foreign policy, relatively independent of both the power blocs in the Cold War period. It enabled India, still a very poor country to play a leading part in the Non-Aligned Movement, a movement which was seen with great suspicion particularly by the US-led bloc. It explains Indira Gandhi's ability to withstand US efforts at playing big brother at India's most vulnerable moments.

Nehru with his personal international prestige and the prestige of the Indian national liberation struggle (which transformed the colonial world) behind him was in the initial years after independence able to pursue an independent foreign policy even before the process of colonial unstructuring had begun to bear fruit fully. However, such a stance was not sustainable in the long run without the Indian economy acquiring a relative autonomy. This was particularly so after Nehru passed away and the glow of the national liberation struggle began to wane.

The Nehruvian years far from being the 'wasted years' laid the foundations of building a sovereign democratic country by 'unstructuring' the colonial structure imposed on India. Without this foundation the Indian economy was not ready for an economic 'take off' as a sovereign nation. It was this foundation, which enabled the Indian economy to participate in globalisation process without compromising its sovereignty and with great advantage to itself, achieving an unprecedented growth trajectory. It is not an 
accident that both the former colonies or semi-colonies like India and China which had faced massive colonial exploitation and had been brought to their knees during the colonial period needed a few decades of colonial 'unstructuring' before they could once again open up to the world and achieve impressive indigenous development.

The Nehru years may have achieved slow growth, though compared to the colonial period they were quite impressive. The growth of per capita income in India in the colonial period was either zero or very low, remaining way below that of the independent countries of Europe, USA and Japan between 1820 and 1913. In the last decades of colonial rule, after colonialism had had its full impact, the per capita income in India actually declined at an annual rate of 0.22 per cent between 1913-1950. After independence, on the other hand, it grew at 1.4 per cent in the first couple of decades between 1950-1973. This was about 3 times faster than the best phase (1870-1913) under colonialism (MADDISON, 2007).

However, it is after the initial Nehruvian decades after independence that the growth rates shoot up, especially after the adoption of economic reforms and the greater participation in the globalization process. Between 1973-2001 the per capita income grew at an annual rate of 3.01 per cent, (a rate considerably higher than that achieved by West Europe, USA or Japan) ${ }^{17}$ and in the four years (2003-4 to 2006-7) at an astounding 7 per cent (it was over 8 per cent in 2006-7) comparable to the explosive rates achieved by Japan (though in very special circumstances) between 1950-73.18 Two points need to be noted about these high growth rates, First, that they were a product of the foundation laid in the Nehruvian period. Second, these growth rates could be achieved without compromising India's sovereignty or the choice of her path of

\footnotetext{
${ }^{17}$ West Europe as a whole grew at 1.88 per cent between 1973 and 2001. Maddison, ibid., p. 643.

${ }^{18}$ Figures for 2001-2007 are based on Economic Survey 2006-07 (New Delhi: Government of India, 2007), Tables 1.2, S-4; and Aditya Mukherjee, "Indian Economy in the New Millennium", in Bipan Chandra, Mridula Mukherjee and Aditya Mukherjee, India Since Independence, (New Delhi: Penguin, 2008). I have taken the per capita income growth rate for 2006-2007 at a conservative 8 per cent. S. Sivasubramonian's comprehensive and detailed study confirms the sharp break in aggregate growth rates as well as in different sectors of the economy between 1900-1947 and 1947-2000. See, e.g., S. Sivasubramonian, The National Income of India in the Twentieth Century (New Delhi: Oxford University Press, 2000), Table 9.35, Fig. 9.5, pp. 622-628.
} 
democracy, again because of the foundations laid in the Nehruvian period.

Quite contrary to the argument of the orthodox Left post-economic reform India has not surrendered her sovereignty to neo-colonial imperialist forces or the so-called 'Washington consensus'. Far from the Indian economy becoming more 'dependent' since the reforms it has considerably improved its bargaining power with external world. While certainly there has occurred a greater integration with the external world it has not occurred at the cost of India losing its sovereignty (MUKHERJEE, 2008). While non-alignment can no longer take the same form as it did during the Cold War period, with the emergence of the so called unipolar world, Indian economic strategy and foreign policy retains the spirit and essence of non-alignment and has refused to get drawn into a junior partner relationship with any country or bloc of countries. India's participation in South-South cooperation, IBSA, BRICS and increasing interest in the ASEAN as well as the look East policy all appear to be under the rubric of non-alignment and opposition to big power hegemonic dominance.

One may add in the end that the commitment to 'democracy', the other imperative apart from the quest for sovereignty, which was bequeathed to Indian people as the legacy of her national liberation struggle, and which Nehru carefully nurtured, was very important in the maintenance of India's independent position. It is easier to dominate a country ruled by 'tin-pot' dictators than a functioning democracy. India would not be easy to push around even if there were certain governments which were weak or ideologically committed to any one bloc because the Indian people as a whole would not accept it.

\section{Conclusion}

To sum up then, the Nehruvian years succeeded in making a paradigmatic break from the colonial past and created the conditions for India entering the economic modernization process. This is quite contrary to the argument of neoliberal enthusiasts and neo-colonialists who demonise the Nehru years, seeing them as the "wasted years" after independence with true development occurring in the colonial period and again only since the economic reforms and India opening up to the global economy (DESAI, 2009; TIRTHANKAR, 2006). It is the structural breaks that the Nehruvian period made in several areas such as creating a diversified industrial capacity, a scientific and technical 
educational infrastructure land reforms, and agricultural transformation that laid the foundation for the subsequent developments. India's developmental breakthrough since the economic reforms was not despite the Nehruvian phase but was made possible because of it.

It is equally wrong to demonise the shift to economic reforms involving a certain liberalization and participation in the globalisation process and seeing it as a sell out to imperialism or as an eminent economist of the Left put it as the nation state now being "dictated by the caprices of a bunch of international rentiers" (PATNAIK, 1998; 2003).

The broad consensus that has emerged in India in recent years, however, does not take such a dim view of the reforms. The commonly perceived need for a shift away from the excessively dirigiste, inward looking and protectionist strategy, which was leading to a dangerous fall in efficiency and productivity levels and the urge to participate in the globalisation process in the altered circumstances of world capitalism in recent decades, where major possibilities had emerged of utilising global capital and global markets for indigenous development, has led to the emergence of a broad consensus in favour of reform. This was a consensus reminiscent of the earlier Nehruvian consensus both in terms of the objectives and width of support. The desire to achieve the same goals set out at independence — of self-reliance, rapid growth and removal of poverty - and not their abandonment, now drew support for reform and the adoption of the new strategy.

The fact that India was able to demonstratively profit by participating in the globalisation process, including by opening its doors considerably to flows of foreign goods, services and capital, without being overwhelmed by it, and that China had continued to follow this path with greater enthusiasm and with remarkable success, further cemented the consensus around the need for change in the direction of economic reform that had emerged in India by 1991. It is no accident that so many of the very people who created, outlined or subscribed to the earlier Nehruvian strategy over time saw the necessity of reform. We have had, for example, apart from Indira Gandhi herself, the radical economist of the Nehruvian era K.N. Raj, the Marxist economist Lord Meghnad Desai, the Nehruvian Narasimha Rao, Left economists Late Sukhamoy Chakravarty, C.H. Hanumantha Rao, Arjun Sengupta and Nobel laureate Amartya Sen, and 
practicing Communist and Chief Minister of West Bengal for the longest tenure since independence, Jyoti Basu, his successor in the Communist led West Bengal Government, Chief Minister Buddhadeb Bhattacharya - all implementing or arguing for economic reform involving liberalisation and participation in the globalisation process, though with different approaches and in varying degrees. Even the BJP despite the strong resistance of the RSS supported Swadeshi Jagaran Manch, is essentially committed to pressing on with reforms.

In this context, it is very instructive to see the position adopted by the former Left Dependency thinker F. H. Cardoso, who as President of Brazil guided the country through economic reform and participation in the globalisation process. He made a major shift from his earlier position and pointed out how the nature of foreign capital had changed and could be used for indigenous development of underdeveloped countries. He argued that globalisation was a fact that could not be ignored, and thus the relevant point of debate is not whether to globalise but how to globalise so that a better bargain be achieved for the backward countries and a proper cushion be provided to the poor so that they are not made to bear the cost of the initial transition. This is a view which the supporters of reform from the Left in India as well as the more sagacious business leaders have generally accepted. Very significantly, Cardoso emphasised that popular mobilisation and community work would be necessary to ensure that that the poor were fully protected. He added that the democratic space in India and the tradition of resistance from the time of Mahatma Gandhi gave India a clear advantage over many other underdeveloped countries (verbal information) (CARDOSO, 1996).

In fact, the recent popular mobilisations in India, leading to progressive legislations by the UPA government after it came to power in 2004, like the National Rural Employment Guarantee Act and Right to Information Act are significant initiatives in the direction of deepening India's democracy and empowering the poor and underprivileged so that the chief challenge facing India today that of reaching to the poor the benefits of its economic success more effectively. 


\section{Aditya Mukherjee}

\section{REFERENCES}

ALAVI, Hamzat. Structure of Colonial Formations. Economic and Political Weekly, Volume XLV, Number 50, 11 December 2010.

AMIN, Samir. Accumulation on a World Scale. New York: Monthly Review Press, 1974. - Accumulation and Development: a Theoretical Model. Review of African Political Economy, 1974.

BLYN, George. Agricultural Trends in India, 1891-1947: Output, Availability, and Productivity. Philadelphia: [s.n.], 1966. pp. 102, 119, 123, 151 and 327.

CARDOSO, Fernando Henrique. Social Consequences of Globalisation. Lecture at India International Centre. New Delhi: 27 January 1996.

CARDoso, Fernando Henrique; FALETTO, Enzo. Dependency and Development in Latin America. Berkeley: University of California Press, 1979.

CHANDRA, Bipan. Colonial Legacy. In: JALAN, Bimal (ed.). The Indian Economy: Problems and Prospects. New Delhi: [s.n], 1992. pp. 8-9.

. The Colonial Legacy. In: CHANDRA, Bipan; MUKHERJEE, Aditya; MUKHERJEE, Mridula. India Since Independence. New Delhi: Penguin, 2008.

. Transformation from a Colonial to an Independent Economy: A Case Study of India. In: id., The Writings of Bipan Chandra: The making of Modern India from Marx to Gandhi. New Delhi: Orient Blackswan, 2012.

CHANDRA, Bipan; MUKHERJEE, Aditya; MUKHERJEE, Mridula. India Since Independence. New Delhi: Penguin, 2008.

DESAI, Meghnad. Address at Bhoothalingam Centenary celebration. In: BHOOTHALINGAM CENTENARY CELEBRATION, 2009, New Delhi, organised by the National Council of Applied Economic Research.

FERGUSON, Niall. Empire: How Britain Made the Modern World. London: Penguin, 2003.

FURnivalL, J. S. Colonial Policy and Practice. New York: New York University Press, 1956.

Netherlands India. New York: [s.n.], 1944.

GEERTZ, Clifford. Agricultural Involution: The Process of Ecological Change in Indonesia. Berkeley: University of California Press, 1963.

GOLDSMITH, Raymond W. The Financial Development of India: 1860-1977. New Haven: Yale University Press, 1983. pp. 20, 68, 80.

GOVERNMENT OF INDIA. Economic Survey 2006-2007. New Delhi: Government of India, 2007.

HABIB, Irfan. Colonisation of the Indian Economy. In: id., Essays in Indian History: Towards a Marxist Perception. New Delhi: Tulika, 1995. pp. 304-306.

HABIB, Seyera. Colonial Exploitation and Capital Formation in England in the Early Stages of Industrial Revolution. In: id, Proceedings of the Indian History Congress. Aligarh: [s.n.], 1975.

HOBSBAWM, Eric. Age of Extremes: The Short Twentieth Century. Harmondsworth: 
Penguin, 1994.

LUTSKY, Vladimir. Modern History of the Arab Countries. Moscow: Progress Publishers, 1969.

KELKAR, Vijay. India and the World Economy: A Search for Self Reliance. In: SEMINAR ON JAWAHARLAL NEHRU AND PLANNED DEVELOPMENT, 1980, New Delhi. Economic and Political Weekly, Volume 15, Numbers 5-7, February 1980.

MADDISON, Angus. The World Economy Volume 1: A Millennial Perspective. Paris: OECD Publications, 2006. Indian Edition, New Delhi: 2007.

The World Economy Volume 2: Historical Statistics. Paris: OECD Publications, 2006. Indian Edition, New Delhi: 2007. p. 641, 643.

MOOSVI, Shireen. The Indian Economic Experience, 1600-1900: A Quantitative Study. In: HABIB, Irfan. The Making of History: Essays Presented to Irfan Habib. New Delhi: Tulika, 2000.

MUKHERJEE, Aditya. Agrarian Conditions in Assam 1880- 1890: A Case Study of Five Districts of the Brahmaputra Valley. The Indian Economic and Social History Review, Volume XVI, Number 2, Apr-June 1979, pp. 207-232.

- Agricultural Growth and the Green Revolution. In: CHANDRA, Bipan; MUKHERJEE, Aditya; MUKHERJEE, Mridula. India Since Independence. New Delhi: Penguin, 2008.

- Economic Challenges 1964-84: From Increased Dirigisme to Beginnings of Liberalization. In: id. (ed.). A Centenary History of the Indian National Congress, Volume V, 1964-84. New Delhi: Academic Foundation, 2011.

. Empire: How Colonial India made Modern Britain. Economic and Political Weekly, Volume XLV, Number 50, 11 December 2010.

. Imperialism, Nationalism and the Making of the Indian Capitalist Class. New Delhi: Sage, 2002.

- Indian Capitalist Class and the Congress on National Planning and the Public Sector. Economic and Political Weekly, Volume 13, Number 35, 1978. In: CHANDRA, Bipan; MUKHERJEE, Aditya; MUKHERJEE, Mridula. India Since Independence. New Delhi: Penguin, 2008.

Indian Economy in the New Millennium. In: CHANDRA, Bipan; MUKHERJEE, Aditya; MUKHERJEE, Mridula. India Since Independence. New Delhi: Penguin, 2008.

. Planned Development in India 1947-65: The Nehruvian Legacy. In: AKITA, Shigeru (ed.). South Asia in the 20th Century International Relations. Tokyo: Institute of Oriental Culture, the University of Tokyo, 2000. CHANDRA, Bipan; MUKHERJEE, Aditya; MUKHERJEE, Mridula. India Since Independence. New Delhi: Penguin, 2008. ch. 25.

. Political Economy of the Postcolonial Indial State. In: CHANDRA, Bipan; MUKHERJEE, Aditya; MUKHERJEE, Mridula. India Since Independence. New Delhi: Penguin, 2008. 
The Indian Economy 1947-65, The Nehruvian Legacy. In: CHANDRA, Bipan; MUKHERJEE, Aditya; MUKHERJEE, Mridula. India Since Independence. New Delhi: Penguin, 2008.

The Return of The Colonial in Indian Economic History: The Last Phase of Colonialism in India. In: INDIAN HISTORY CONGRESS (MODERN INDIA), 2007, New Delhi. Social Scientist, Volume 36, Numbers 3-4, MarchApril 2008. Social Science Probings, June 2008.

MUKHERJEE, Aditya (ed.). A Centenary History of the Indian National Congress, Volume V, 1964-84. New Delhi: Academic Foundation, 2011.

MUKHERJEE, Mridula. Colonialising Agriculture: The Myth of Punjab Exceptionalism. New Delhi: Sage, 2006. pp. 157-161.

MUKHERJEE, Aditya; MUKHERJEE, Mridula. Imperialism and the Growth of Indian Capitalism in the Twentieth Century. Economic and Political Weekly, 12 March 1988.

MUNDLE, Sudipto. State Character and Economic Policy. Social Scientist, Volume 2, Number 10, May 1974.

NEHRU, Jawaharlal. et al. Selected Works of Jawaharlal Nehru, Second Series: Volume 28: 1 February - 31 May 1955. New York: Oxford University Press, 2001. p. 371 .

PATNAIK, Utsa. New Estimates of Eighteenth-Century British Trade and Their Relation to Transfers from Tropical Colonies. In: HABIB, Irfan. The Making of History: Essays Presented to Irfan Habib. New Delhi: Tulika, 2000.

RAJ, K. N. Indian Economic Growth: Performance and Prospects. New Delhi: Allied Publishers, 1965.

SEN, Amartya. Poverty and Famines: An Essay on Entitlements and Deprivation. Deli: Oxford University Press, 1982. Appendix D, pp.195-216.

SIVASUBRAMONIAN, S. The National Income of India in the Twentieth Century. New Delhi: Oxford University Press, 2000. pp. 622-628.

TIRTHANKAR, Roy. The Economic History of India: 1857-1947. New Delhi: Oxford University Press, 2000. Second edition: 2006.

VAIDYANATHAN, A. The Indian Economy Since Independence (1947-70). In: KUMAR, Dharma. The Cambridge Economic History of India: Volume 2, c. 1751 - c.1970. Cambridge: Cambridge University Press, 1983. p. 961. 


\begin{abstract}
In this paper, I shall argue, in brief, that the colonial legacy did not create positive "initial conditions" and that the path to development necessitated the 'unstructuring' of colonialism. Second, I shall outline elements of the Nehruvian strategy for 'unstructuring' colonialism showing that the Nehruvian period rather than being wasted or leading to further dependency actually promoted independent development and created the structural conditions for rapid development in later years. The Nehruvian strategy, which I call the 'Nehruvian consensus' at independence, was a product of a particular historical conjuncture. 'Non-alignment' was one aspect of this consensus. The historical conjuncture was constituted by a number of factors such as the legacy of colonialism or the "initial conditions" at the point of independence, the nature of world capitalism and the global balance of power at that time.
\end{abstract}

\title{
KEYWORDS
}

South-South Cooperation; India; Globalization; 


\section{PARTNERS}

\section{NERINT}

The Brazilian Center for Strategy and International Relations (NERINT) was the first center dedicated exclusively to the study and research in international relations in Southern Brazil. It was established in 1999 at the Latin American Institute for Advanced Studies (ILEA), within the Federal University of Rio Grande do Sul (UFRGS), Porto Alegre (known for hosting the World Social Forum), Brazil. Its main goal has always been the study of main transformations within the post-Cold War international system through an innovative and argumentative perspective. Also, NERINT has always sought ways to contribute to the discussion of a renewed national project for Brazil through the understanding of the available strategic options to consolidate an autonomous international presence for the country from the perspective of the developing world.

Brazil's choice of an "active, affirmative, and proactive diplomacy" at the beginning of the $21^{\text {st }}$ century has converged with projections and studies put forward over numerous seminars and publications organized by NERINT (2 collections amounting to 24 published volumes). Exploratory studies on the new areas of active engagement by developing countries have proven themselves correct and have met remarkable development over the years. Over the years, cooperation with States, business, academic, and social institutions has been intensified. Similar developments have also been made through direct contact with centers in Latin American, African, and Asian centers, not to mention the growing interactions with previous partners from Europe and North America.

Among the positive outcomes that are a direct consequence of this new reality are the implementation of an undergraduate degree on International Relations (2004) and a graduate level program, the International Strategic Studies Doctoral Program (2010); and the launching of two journals - the bimonthly Conjuntura Austral and the biannual and bilingual Austral: Brazilian Journal of Strategy \& International Relations. Thus, besides ongoing research on developing countries, NERINT is also the birthplace of 
undergraduate and graduate programs, not to mention its intense editorial activities.

\section{PPGEEI}

The International Strategic Studies Doctoral Program (PPGEEI) started in 2010/2011, offering a Masters and a Doctorate degrees both supported by qualified professors and researchers with international experience. It is the result of several developments on research and education at the Federal University of Rio Grande do Sul (UFRGS) and its roots can be traced to the Brazilian Center of Strategy and International Relations (NERINT), a center established in 1999 which conducts research, seminars, and edits two journals. Other main partners are the Center for Studies on Technology, Industry, and Labor (NETIT/FCE) and the Center for International Government Studies (CEGOV), located at the Latin American Institute for Advanced Studies (ILEA/UFRGS). In 2004, an undergraduate degree in International Relations was created at the Faculty of Economics/UFRGS; in 2005 came the Center for Studies on Brazil-South Africa (CESUL), recently renamed as Brazilian Centre for African Studies (2012). All those actions together enabled the rise of an independent line of thinking propped by specialized bibliography.

The research tradition that gave rise to PPGEEI was based on a prospective analysis of the trends of the 1990s. The remarkable expansion of Brazilian diplomacy and economics from the beginning of the century confirmed the perspective adopted, which allowed the intense cooperation with the diplomatic and international economic organizations in Brazil. The course is already a reference in the strategic analysis of the integration of emerging powers in international and South-South relations.

The Program's vision emphasizes strategic, theoretical and applied methods, always relying on rigorous scientific and academic principles to do so. For this reason, it has been approached by students from all over Brazil and several other countries and it has established partnerships in all continents. Thus, the Graduate Program in International Strategic Studies is a program focused on understanding the rapid changes within the international system. Alongside NERINT, it publishes two journals: Conjuntura Austral (bimonthly) 


\section{Partners}

and Austral: Brazilian Journal of Strategy \& International Relations (biannual and bilingual).

PPGEEI has three research lines:

\section{International Political Economy}

It focuses on the international insertion of the Brazilian economy and other major developing countries in South America, Asia and Africa; discusses the characteristics and effects of globalization; and develops comparative and sector studies concerned with the effects of the internationalization of companies and productive sectors. Special attention is paid to international financial crises and its effects in Brazil and other countries of the South.

\section{Foreign Policy and Regional Integration}

It emphasizes the analysis of the process of formation, implementation and evaluation of foreign policy. It seeks to confront patterns of international integration of strategic countries of South America, Africa and Asia, considering institutional patterns, trade policy structures of intermediation of interests, and agents of civil society in the South-South axis of contemporary international relations.

\section{Technology, State and International Security}

It discusses the leading security issues in the international system from a perspective that takes into account the most powerful states at the global level, but which introduces in a systematic way the problem of the regional balances of power, the South-South axis, the existence of regional security complexes and the impact of information technology in the Digital Age.

\section{BRAZILIAN CENTRE FOR AFRICAN STUDIES (CEBRAFRICA)}

The Brazilian Centre for African Studies (CEBRAFRICA) has its origins in Brazil-South Africa Studies Centre (CESUL), a program established in 2005 through an association between the Universidade Federal do Rio Grande do Sul (UFRGS) and Fundação Alexandre de Gusmão (FUNAG), of the Brazilian Ministry of Foreign Affairs. Its research activities are developed within the 
Brazilian Centre for Strategy and International Relations (NERINT), located in the Latin American Institute for Advanced Studies (ILEA) of UFRGS.

In March 2012, CESUL was expanded into CEBRAFRICA in order to cover the whole of Africa. At the same time, the South Africa series, which published five books, was transformed into the African Series, with new titles on the way. The center's main objectives remain the same as before: to conduct research, to support the development of memoires, thesis and undergraduate memoires, to congregate research groups on Africa, to organize seminars, to promote student and professor exchanges with other institutions, to establish research networks and joint projects with African and Africanist institutions, to publish national and translated works on the field, and to expand the specialized library made available by FUNAG.

The numerous research themes seek to increased knowledge of the African continent and its relations to Brazil on the following topics: International Relations, Organizations and Integration, Security and Defense, Political Systems, History, Geography, Economic Development, Social Structures and their Transformations, and Schools of Thought. CEBRAFRICA counts among its partners renowned institutions from Brazil, Argentina, Cuba, Mexico, Canada, South Africa, Angola, Mozambique, Senegal, Cape Verde, Egypt, Nigeria, Morocco, Portugal, United Kingdom, Netherlands, Sweden, Russia, India, and China. Current researches focus on "Brazilian, Chinese, and Indian Presence in Africa", "Africa in South-South Cooperation", African Conflitcs", Integration and Development in Africa", "African Relations with Great Powers", and "Inter-African Relations). 


\section{SUBMISSION STANDARDS}

1.AUSTRAL: Brazilian Journal of Strategy \& International Relations publishes articles and book reviews;

2.The journal is divided in two sections: Articles (Artigos) and Book Review (Resenhas);

3.The research articles must contain a maximum of 50 thousand characters (including spaces and footnotes) Use only the standard format; the book reviews must contain a maximum of 4,5 thousand characters (spaces and footnotes included);

4.The footnotes should be strictly of a substantive and complementary nature;

5.The bibliography must follow the rules of the Chicago system (Author, date), specifying the used literature at the end of the text;

6. Contributions must be original and unpublished and can be submitted in Portuguese, English or Spanish;

7.All authors must fill out the Submission Form;

8. Contributions must contain the full name of the author, their titles, institutional affiliation (the full name of the institution) and an email address for contact;

9.Publications of undergraduate students are accepted, as long as in partnership with an advisor professor, which will appear as the main author of the work;

10. Book reviews must contain the complete data and the ISBN of the analyzed work;

11. Contributions must be accompanied of: 3 keywords in Portuguese or Spanish and 3 keywords in English; Title in English and in Portuguese or Spanish; Abstract in English and in Portuguese or Spanish, both with up to 50 words.

12. Submissions must be made by the journal website: www.seer.ufrgs.br/Austral

\section{SUBMISSION PREPARATION GHEGKLIST}

As part of the submission process, authors are required to check off their submission's compliance with all of the following items, and submissions may be returned to authors that do not adhere to these guidelines.

1. Contributions must be original, and shall not have been submitted for publication in another journal; otherwise, it must be justified in "Comments to the Editor".

2. Submitted files must be in Microsoft Word, OpenOffice or RTF (as long as their size is up to $2 \mathrm{MB}$ ) format.

3. URLs must be informed in the references when necessary.

4. The text must be single-spaced; Times New Roman typeface 12 pt must be used for the body of the text; italic is to be used instead of underline (except in URL addresses); Figures and Tables must be embedded in the text.

5. The text must follow patterns of style and bibliographical requirements described in Author Guidelines, in the section "About the Journal".

6. The identification of authorship of the work must be removed from the file and the Properties option in Word, thus ensuring the confidentiality criteria of the journal, if it is to be subjected to peer review (i.e. articles), accordingly with available instructions in the website. 


\title{
PREVIOUS ISSUES
}

\section{Volume 1, Number 1 (Jan/Jun 2012)}

Presentation

Celso Amorim

Editor's Note

Paulo Visentini

The Future of MERCOSUR

Samuel Pinheiro Guimarães

The Brazil of Lula : A global and affirmative diplomacy (2003-2010)

Paulo Visentini

Russia turning on Latin America

Yuri Paniev

Reordering International Affairs: the Forum on China-Africa Cooperation Mamoudou Gazibo, Olivier Mbabia

The Jacob Zuma Government's Foreign Policy: Association or Dissociation?

Chris Landsberg.

South-South Cooperation and the Changing Role of the Gulf States Kristian Coates Ulrichsen

The financial Crisis and the Dollar Hegemony

Marcelo Milan

\author{
Available Online on: \\ www.seer.ufrgs.br/Austral
}




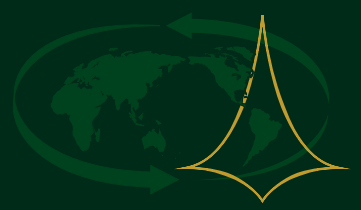

Brazilian national identity, ethnically heterogeneous and culturally plural, of a nation with tremendous social inequalities and eager for development, formed the basis of the country's external conduct. Brazilian foreign policy goes [...] towards the maturity of international integration. Thereby, the twenty-first century is the advanced point of arrival of a new country, in search of her own destiny. [...] Thus emerges society, with organized segments, active leaderships, specific interests to accomplish, and will to move forward.

AMADO CERVO

This journal should reflect the academic perspective of the developing world, the "South", and now this old dream becomes reality, born from a long, careful and thoughtful preparation. It is the first brazilian journal of strategy and international relations entirely in English, an essentially academic publication dedicated to international political and economical issues, with emphasis on developing countries' diplomacy, which usually receives limited or ethnocentric attention from major international journals. The main focuses of the publication are South-South relations, security issues, economical, political and diplomatic development in emerging nations and their relations with the traditional powers in a context of crisis and transition of the internationalorder.

EDITOR

\section{Brazilian Foreign Policy and South-South Cooperation}

The Lessons from the Euro Experience

Richard Griffiths

Brazil in the Current World Order

Amado Luiz Cervo

Neo-developmentalism and the Search of a New International Insertion

Giorgio Romano

Teaching and research on Foreign Policy in the Field of International Relations of Brazil

Carlos Aurélio Pimenta de Faria

Brazil in face of the Chinese Rise: the Risks of Regressive Specialization

André Cunha, Marcos Lélis, Julimar Bichara, Manuela de Lima

The Impact of the International Crisis on Brazil's Trade with the Other BRICS (Russia, India, China And South Africa)

André Luiz Reis da Silva, Luiza Peruffo

Media And Foreign Policy in Lula's Brazil

Guilherme Casarões

Developing from the South: South-South Cooperation in the Global Development Game

Sean Burges

Colonial Globalisation to Postcolonial Globalisation: Non-Alignment and South-South Cooperation

Aditya Mukherjee
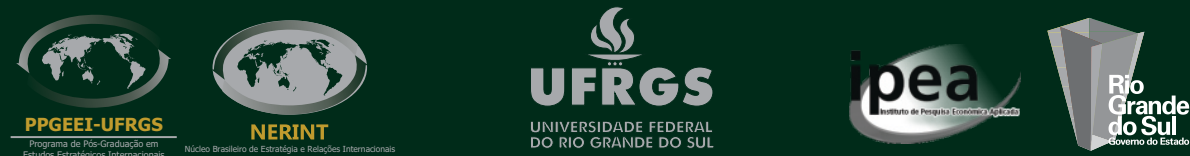
